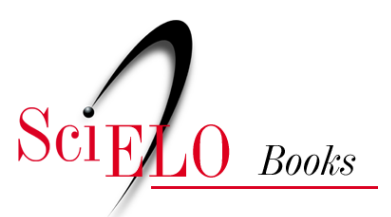

\title{
A família Asteraceae no Brasil classificação e diversidade
}

\author{
Nádia Roque \\ Aristônio Magalhães Teles \\ Jimi Naoki Nakajima \\ (Organizadores)
}

ROQUE, N. TELES, A.M., and NAKAJIMA, J.N., comp. A família Asteraceae no Brasil: classificação e diversidade [online]. Salvador: EDUFBA, 2017, 260 p. ISBN: 978-85-232-1999-4.

https://doi.org/10.7476/9788523219994.

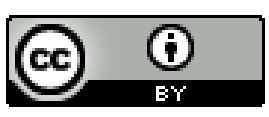

All the contents of this work, except where otherwise noted, is licensed under a Creative Commons Attribution 4.0 $\underline{\text { International license. }}$

Todo o conteúdo deste trabalho, exceto quando houver ressalva, é publicado sob a licença Creative Commons Atribição $\underline{4.0}$. 


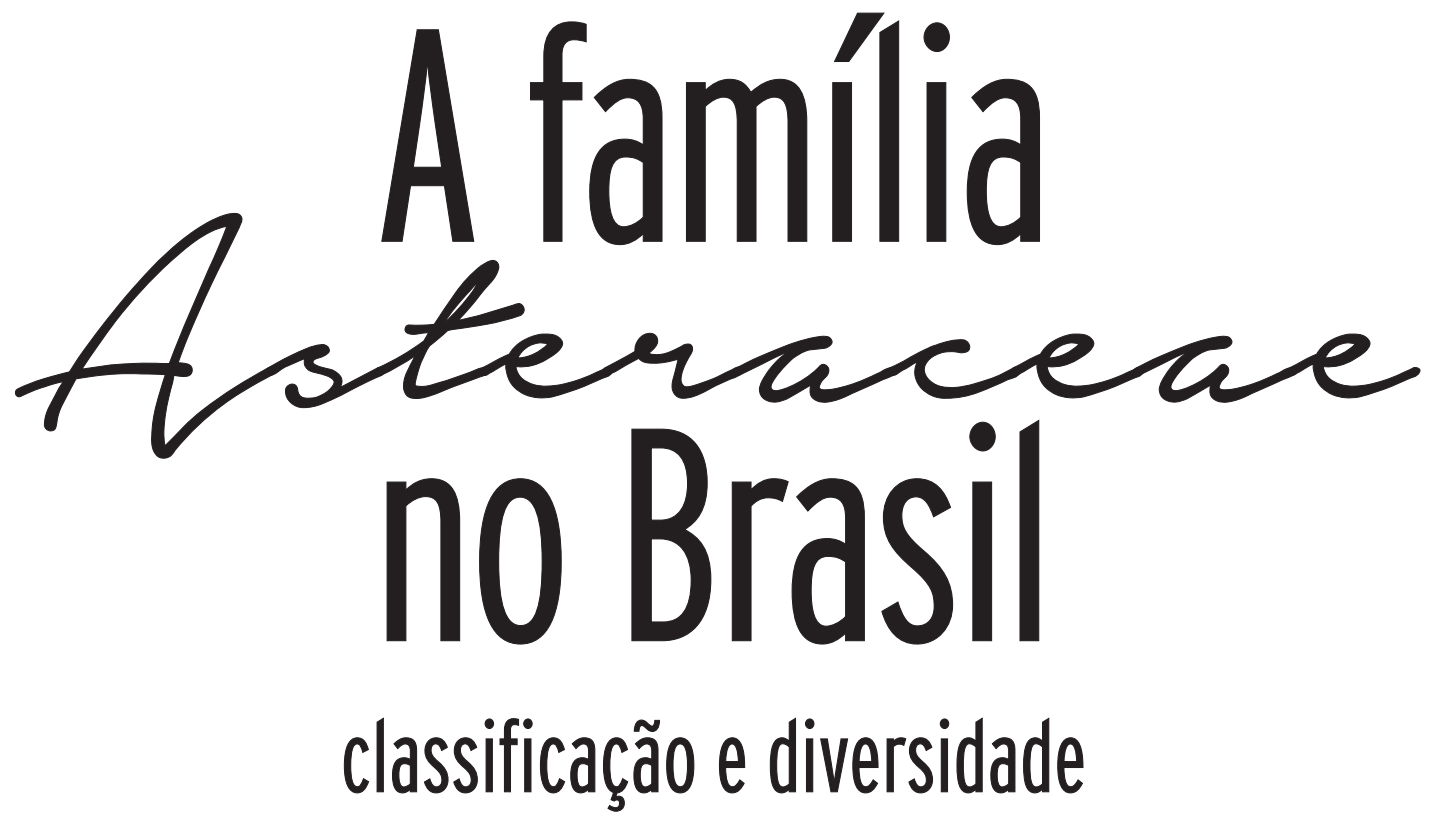


UNIVERSIDADE FEDERAL DA BAHIA

REITOR

João Carlos Salles Pires da Silva

VICE-REITOR

Paulo Cesar Miguez de Oliveira

ASSESSOR DO REITOR

Paulo Costa Lima

INSTITUTO DE BIOLOGIA

DIRETOR

Francisco Kelmo

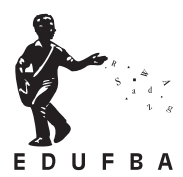

EDITORA DA UNIVERSIDADE FEDERAL DA BAHIA

DIRETORA

Flávia Goulart Mota Garcia Rosa

CONSELHO EDITORIAL

Alberto Brum Novaes

Angelo Szaniecki Perret Serpa

Caiuby Alves da Costa

Charbel Ninõ El-Hani

Cleise Furtado Mendes

Evelina de Carvalho Sá Hoisel

José Teixeira Cavalcante Filho

Maria do Carmo Soares de Freitas

Maria Vidal de Negreiros Camargo 


\author{
NÁDIA ROQUE \\ ARISTÔNIO MAGALHÃES TELES \\ JIMI NAOKI NAKAJIMA \\ ORGANIZADORES
}

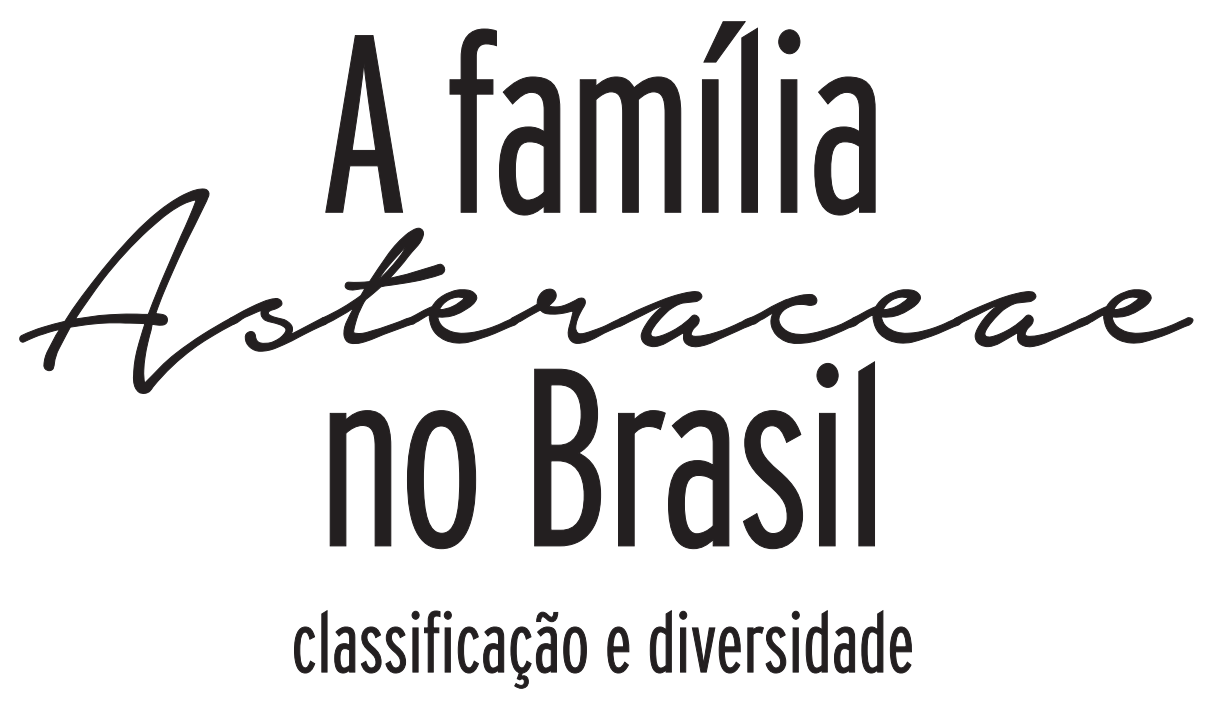

SALVADOR
EDUFBA
2017 
2017, autores.

Direitos para esta edição cedidos à Edufba.

Feito o Depósito Legal.

Grafia atualizada conforme o Acordo Ortográfico da Língua Portuguesa de 1990,

em vigor no Brasil desde 2009.

CAPA E PROJETO GRÁFICO

Gabriela Nascimento

REVISÃO

Mariana Rios Amaral de Oliveira

NORMALIZAÇÃO

Sandra Batista

ILUSTRAÇÕES

Natanael Nascimento dos Santos

Dados Internacionais de Catalogação na Publicação (CIP)

Elaboração: Sandra Batista de Jesus - CRB-5/1914

F198 A família Asteraceae no Brasil: classificação e diversidade / Nádia Roque, Aristônio Magalhães Teles e Jimi Naoki Nakajima (organizadores). Salvador: EDUFBA, 2017.

260 p. : il.

ISBN: 978-85-232-1664-1

1. Botânica. 2. Botânica - Classificação. 3. Plantas - Brasil. I. Título. II. Roque, Nádia. III. Teles, Aristônio Magalhães. IV. Nakajima, Jimi Naoki.

CDD 582.98

Editora filiada à

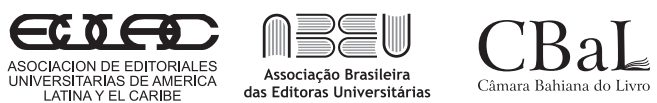

Editora da UFBA

Rua Barão de Jeremoabo

s/n - Campus de Ondina

40170-115 - Salvador - Bahia

Tel.: +55 71 3283-6164

Fax: +55 71 3283-6160

www.edufba.ufba.br

edufba@ufba.br 


\section{APRESENTAÇÃO}

Uma queixa recorrente entre colegas botânicos e alunos de graduação e pós-graduação é a dificuldade em identificar táxons da família Asteraceae, considerada uma das maiores entre as angiospermas. Além dessa elevada riqueza, as mudanças na circunscrição de gêneros, em especial de Eupatorium e Vernonia, bem como na recente classificação de subfamílias e tribos, evidenciam a necessidade de uma bibliografia atualizada. Basicamente, as chaves disponíveis são a da Flora brasiliensis, produzida por John Gilbert Baker entre 1873 e 1884, e a do volume 3 do livro Sistemática de angiospermas do Brasil, de autoria da saudosa doutora Graziela Maciel Barroso e colaboradores, cuja a última edição foi publicada em 1991. Embora esses dois trabalhos sejam historicamente importantes, eles se encontram desalinhados às mudanças na forma como hoje compreendemos as relações entre os táxons da família Asteraceae.

A partir dessa demanda, foi proposta uma meta para o Projeto Reflora/ CNPq: a construção de uma chave ilustrada para tribos e gêneros no Brasil. Em 2013, quando estávamos trabalhando nos herbários do Museu de História Natural da França, em Paris, e do Jardim Botânico Real de Kew, em Londres, essa proposta foi ampliada para a publicação de um livro sobre as Asteraceae do Brasil. Sabíamos que o desafio era grande, mas que tínhamos, em nosso país, um número de especialistas que seguramente colaboraria na confecção de um produto de qualidade e que atenderia à comunidade botânica.

A partir de então, idealizamos o formato do livro e reunimos um time de 38 autores, entre brasileiros e estrangeiros, que contribuíram com a redação de 28 capítulos e um glossário palinológico, abordando todas as 27 tribos e os 310 gêneros com representantes nativos, cultivados e subespontâneos que ocorrem no país.

Neste formato, a introdução refere-se ao histórico taxonômico e descrição morfológica da família, incluindo uma chave diagnóstica para as tribos ocorrentes no Brasil. Os 27 capítulos subsequentes tratam individualmente de cada tribo e apresentam informações taxonômicas, riqueza de gêneros 
e espécies, bem como distribuição geográfica, descrição morfológica, chave de identificação para gêneros e literatura recomendada. Ao final do livro são apresentados três apêndices: o primeiro inclui um glossário palinológico ilustrado; o segundo, um índice de autores de figuras e coletores; e, por fim, um índice de nomes científicos cujos táxons encontram-se citados e ilustrados ao longo do livro, seja por meio de desenhos a nanquim ou fotografias.

Com muito prazer e unanimidade entre os autores, homenageamos, neste livro, a primeira dama da botânica no Brasil, a doutora Graziela Maciel Barroso (1912-2003), que contribuiu sobremaneira tanto para a formação de importantes sinanterólogos, quanto para o conhecimento e divulgação da família Asteraceae no país, descrevendo gêneros e espécies novas, bem como confeccionando monografias, revisões taxonômicas e trabalhos de flora.

Por fim, esperamos que este livro, fruto de um esforço conjunto de vários especialistas, desmistifique o senso comum de que os gêneros de Asteraceae são de difícil identificação e, como resultado, que possamos estimular a formação de novos sinanterólogos. Esperamos, ainda, que ele seja de grande utilidade para a comunidade botânica brasileira, como livro texto em cursos de graduação e pós-graduação em botânica e áreas afins, ou simplesmente auxiliando na identificação de táxons dessa importante e diversa família presente na nossa flora. Além disso, estamos abertos a críticas, acréscimos e sugestões, que serão muito bem-vindos para as edições futuras.

Os organizadores

2017 


\section{SUMÁRIO}

Prefácio

José Rubens Pirani

Dedicatória

Graziela Maciel Barroso

Autores

1 Introdução

2 Tribo Barnadesieae D. Don

3 Tribo Mutisieae Cass. 43

4 Tribo Nassauvieae Cass. 51

5 Tribo Onoserideae (Bentham) Panero \& V.A. Funk 57

6 Tribo Stifftieae D. Don 61

7 Tribo Wunderlichieae Panero \& V.A. Funk 67

8 Tribo Hyalideae Panero 73

9 Tribo Gochnatieae (Benth. \& Hook. f.) Panero \& V.A. Funk 77

10 Tribo Tarchonantheae Kostel. 81

11 Tribo Cardueae Cass. 85

12 Tribo Cichorieae Lam. \& DC. 89

13 Tribo Liabeae (Cass. ex Dumort.) Rydb. $\quad 97$

14 Tribo Vernonieae Cass. 101

15 Tribo Moquinieae H. Rob. 119

16 Tribo Senecioneae Cass. 123

17 Tribo Gnaphalieae (Cass.) Lecoq. \& Juill. 131

18 Tribo Astereae Cass. 139

19 Tribo Anthemideae Cass. 149

20 Tribo Inuleae Cass. 153

21 Tribo Helenieae Lindl. 161 
22 Tribo Coreopsideae Lindl.

23 Tribo Neurolaeneae Rydb.

24 Tribo Tageteae Cass.

25 Tribo Bahieae B.G. Baldwin

26 Tribo Heliantheae Cass.

27 Tribo Millerieae Lindl.

28 Tribo Eupatorieae Cass. 


\section{PREFÁCIO}

Foi, para mim, motivo de grande júbilo ser convidado a preparar um prefácio para este livro, que trata de uma das mais diversificadas famílias de plantas do mundo e que surge como mais um marco nos estudos sobre a rica flora brasileira. Idealizado e coordenado por 3 importantes sinanterólogos do Brasil, Nádia Roque, Aristônio Magalhães Teles e Jimi Naoki Nakajima, o livro contém uma rica introdução geral sobre a família Asteraceae e contibuições de um total de 38 autores de diversas instituições brasileiras e de outros países. Esses especialistas prestaram seu conhecimento e experiência compilando capítulos sobre as 27 tribos de Asteraceae representadas no Brasil, conforme circunscritas com base em estudos filogenéticos modernos, e as chaves de identificação para o acesso aos 310 gêneros aqui ocorrentes. A meu ver, entre os vários méritos deste livro, destaca-se essa integração entre botânicos de diferentes instituições, num processo salutar de intercâmbio e atualização recíproca.

Sinto-me gratificado e imensamente feliz em ver, entre os autores, os ex-alunos que formei em Asteraceae, por meio de projetos de iniciação científica, mestrado e doutorado, num período em que eu sentia a necessidade de incremento de profissionais brasileiros dedicados ao estudo da família. E sei que os orientadores em sinanterologia de outras instituições devem sentir-se como eu, contentes em acompanhar a evolução e progressos de tantos colegas e alunos, labutando nos vários grupos dessa família extraordinária, no mister de atualizar as circunscrições taxonômicas, ampliando o conhecimento sobre os gêneros e suas espécies e trazendo descobertas de novas espécies ou registros de novas ocorrências no país. Se nossa querida e saudosa Graziela Maciel Barroso ainda estivesse entre nós, estaria igualmente satisfeita e feliz!

Os tratamentos das tribos de Asteraceae, neste livro, trazem relevante atualização taxonômica e apresentam descrições morfológicas detalhadas das tribos, chaves de identificação para tribos e para todos os gêneros representados no Brasil, além de ótimas ilustrações. Um glossário ilustrado de termos palinológicos enriquece o conteúdo, face à notória importância 
dos caracteres polínicos na sistemática da família. A acurácia e atualidade dos dados apresentados em seus capítulos tornam este livro a obra mais abrangente, completa e atual sobre os grupos de Asteraceae no Brasil. Em muitas instâncias, o valor de seu conteúdo transcende os limites do país, pois muitos dos gêneros aqui tratados estendem-se para países vizinhos.

Tenho plena certeza da enorme importância e utilidade de mais este passo no estudo de Asteraceae e da flora brasileira, e parabenizo todos os autores envolvidos; em especial, os editores, que se esmeraram em garantir o alto padrão de qualidade dos dados apresentados. Ainda há muito a fazer rumo ao conhecimento detalhado das espécies de muitos dos gêneros aqui tratados, porém a compilação dessas informações atualizadas neste livro representa avanço de enorme valor para estudos sobre Asteraceae em outros ramos da ciência botânica e ainda para esforços de conservação biológica. O conteúdo do livro constitui também material didático de ótima qualidade, que vai subsidiar a formação de novos pesquisadores.

Assim, eu parabenizo todos os que se envolveram na produção do presente livro, na certeza de sua grande importância e de seu imediato sucesso.

São Paulo, 2017.

Dr. José Rubens Pirani

Universidade de São Paulo 
À mais notável botânica brasileira

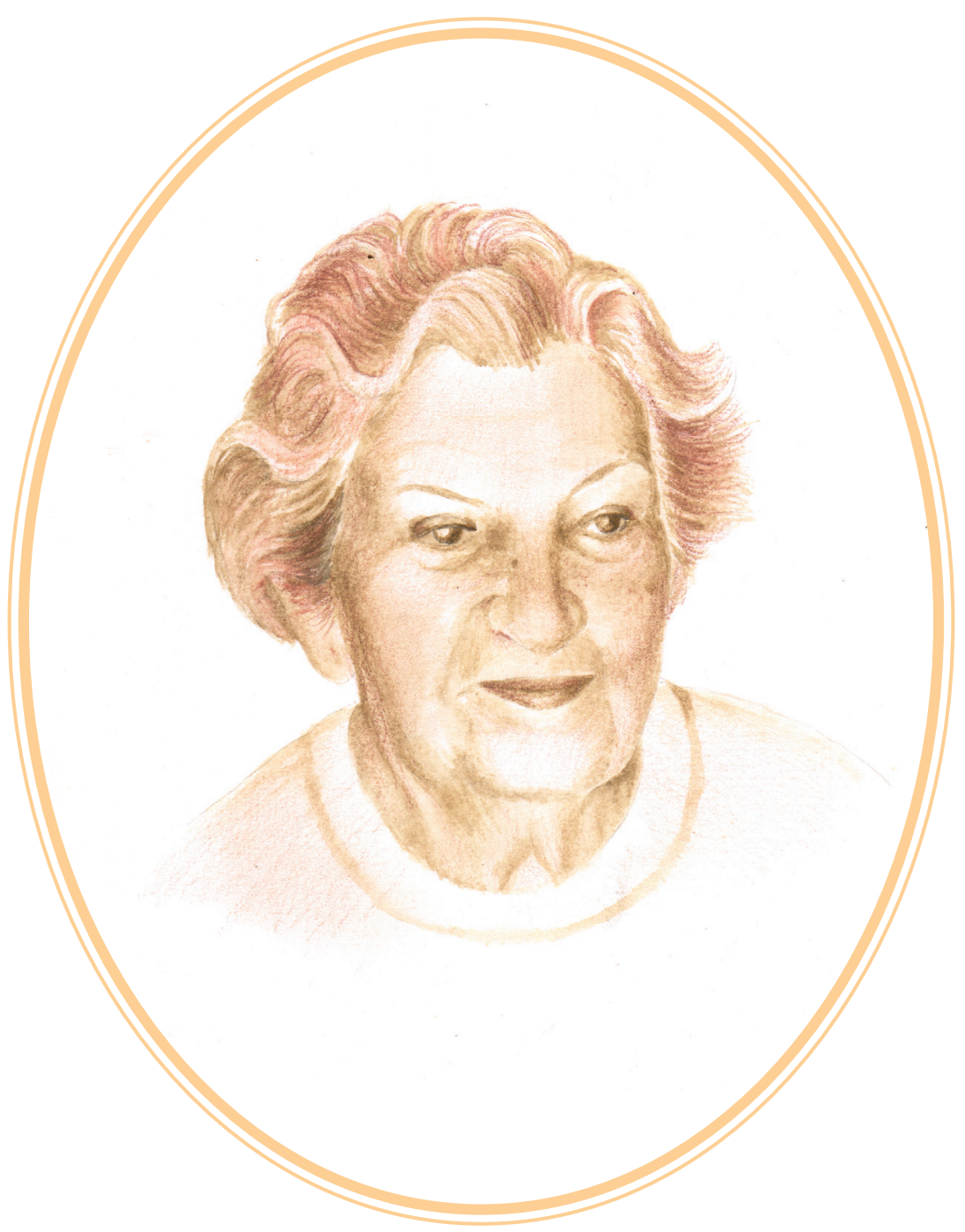

GRAZIELA MACIEL BARROSO

(1912-2003) 


\section{AUTORES}

\section{Aline Silva Quaresma (28)}

Rua José Arcênio Silva, 91, Mangabeiras. CEP: 35930-185, João Monlevade, Minas Geras, Brasil.

E-mail: alinesilvaquaresma@yahoo.com.br

\section{Ana Claudia Fernandes (28)}

Universidade Federal do Tocantins, Campus Gurupi, prédio Bala I, Rua Badejós, Lote 7, Chácaras 69/72, Zona Rural. 77402-970, Gurupi, Tocantins, Brasil.

E-mail: nlana2003@gmail.com

Angelo A. Schneider (11, 12, 18, 19)

Universidade Federal do Pampa, Campus São Gabriel. 97300-000, São Gabriel, Rio Grande do Sul, Brasil.

E-mail: angeloschneider@yahoo.com.br

Aristônio M. Teles $(1,16,19)$

Universidade Federal de Goiás, Instituto de Ciências Biológicas, Departamento de Botânica, Campus Samambaia, Av. Esperança, s/n, Vila Itatiaia. 74690-900, Goiânia, Goiás, Brasil.

E-mail: teles@ufg.br

Arne A. Anderberg (20)

Swedish Museum of Natural History, Department of Botany, P.O. Box 50007, SE-104 05, Estocolmo, Suécia.

E-mail: arne.anderberg@nrm.se

\section{Benoit Loeuille (14)}

Universidade Federal de Pernambuco, Centro de Ciências Biológicas, Departamento de Botânica, Rua Professor Nelson Chaves, s/n, CDU. 50670420, Recife, Pernambuco, Brasil.

E-mail: benoit.loeuille@gmail.com 


\section{Cellini Castro de Oliveira (13)}

Universidade de Brasília, Instituto de Ciências Biológicas, Departamento de Botânica, campus Darcy Ribeiro, Caixa Postal 04457. 70919-970. Brasília, Distrito Federal, Brasil.

E-mail: cellini.castro.de.oliveira@gmail.com

Cláudia Barbieri Ferreira Mendonça $(14,29)$

Universidade Federal do Rio de Janeiro, Museu Nacional, Departamento de Botânica, Quinta da Boa Vista, Horto Botânico, Laboratório de Palinologia, São Cristóvão. 20940-040, Rio de Janeiro, Rio de Janeiro, Brasil.

E-mail: cb.mendonca@gmail.com

\section{Danilo Marques (14)}

Universidad Nacional del Nordeste, Instituto de Botánica del Nordeste (UNNE-CONICET), Av. Sargento Cabral, C.C. 209, W3400CBL. Corrientes, Argentina.

E-mail: danilobioufu@gmail.com

Eduardo Pasini $(3,5)$

Marquês do Herval, 345. 95020-260, Caxias do Sul, Rio Grande do Sul, Brasil. E-mail: eddpasini@gmail.com

Eric K. O. Hattori (28)

Universidade Federal dos Vales do Jequitinhonha e Mucuri, Instituto de Ciências Agrárias, Campus Unaí, Av. Vereador João Narciso, 1380. 38610000. Unaí, Minas Gerais, Brasil.

E-mail: erichattori@gmail.com

Fátima Otavina Souza-Buturi $(4,7)$

Instituto de Botânica, Núcleo de Pesquisa Curadoria do Herbário SP, Centro de Pesquisas em Plantas Vasculares, Av. Miguel Stefano, 3687, Água Funda, 04301-902. São Paulo, São Paulo, Brasil.

E-mail: fatimaosouza@yahoo.com.br 
Fernanda Santos Freitas (16)

Rua Prof. Ciro de Castro Almeida, 1916, Custódio Pereira. Uberlândia, Minas

Gerais, Brasil.

E-mail: freitas.fernandasantos@gmail.com

\section{Gisela Sancho (9)}

Museo de La Plata, División Plantas Vasculares, Paseo del Bosque, s/n, 1900.

La Plata, Argentina.

E-mail: sancho@fcnym.unlp.edu.ar

Giselle Lopes Moreira (13)

Universidade de Brasília, Instituto de Ciências Biológicas, Departamento de Botânica, campus Darcy Ribeiro, Caixa Postal 04457. 70919-970. Brasília, Distrito Federal, Brasil.

E-mail: gisellebio25@gmail.com

Gustavo Heiden $(10,18)$

Embrapa Clima Temperado, BR 392, km 78, Caixa Postal 403. 96010-971. Pelotas, Rio Grande do Sul, Brasil.

E-mail: gustavo.heiden@embrapa.br

Helen A. Ogasawara (15)

Rua Luiz Anselmo, 571, Ed. Arturo Toscanini, apartamento 2014, Matatu. Salvador, Bahia, Brasil.

E-mail: ayumi.ogasawara@yahoo.com.br

Jimi Naoki Nakajima $(1,14,28)$

Universidade Federal de Uberlândia, Instituto de Biologia, Rua João Naves, de Ávila, 2121, Campus Umuarama. 38400-902. Uberlândia, Minas Gerais, Brasil.

E-mail: nakajima@ufu.br 
João Bernardo de A. Bringel Jr. (21, 22, 24, 25, 26, 27)

Embrapa Recursos Genéticos e Biotecnologia - CENARGEN, Parque Estação Biológica, PqEB, Av. W5 Norte. 70770-900. Brasília, Distrito Federal, Brasil. E-mail: jbbringel@gmail.com

João de Deus Medeiros (10)

Universidade Federal de Santa Catarina, Centro de Ciências Biológicas, Departamento de Botânica, Campus Universitário, Trindade. 88040-900, Florianópolis, Santa Catarina, Brasil.

E-mail: j.d.medeiros@ufsc.br

João Semir $(4,7,20)$

Universidade Estadual de Campinas, Instituto de Biologia, Av. Monteiro Lobato, 970. 13083-970. Campinas, São Paulo, Brasil.

E-mail: semir@uicamp.br

Leonardo Paz Deble (17)

Universidade Federal do Pampa, Campus Universitário de Dom Pedrito. 94450-000. Dom Pedrito, Rio Grande do Sul, Brasil.

E-mail: deble.biol@gmail.com

\section{Liliana Katinas (7)}

Museo de La Plata, División Plantas Vasculares, Paseo del Bosque, s/n, 1900.

La Plata, Argentina.

E-mail: katinas@fcnym.unlp.edu.ar

\section{Lúcia Moura Conti (6)}

Praça dos Garimpeiros, Condomínio Point da Chapada, Casa 12. 46750-000. Mucugê, Bahia, Brasil.

E-mail: luciamouraconti@gmail.com

Mara Angelina Galvão Magenta $(21,22,24,25,26,27)$

Universidade Santa Cecília, Departamento Botânica, Rua Oswaldo Cruz, 277, Boqueirão. 11045-90, Santos, São Paulo, Brasil.

E-mail: maramagenta@unisanta.br 
Mara Rejane Ritter (28)

Universidade Federal do Rio Grande do Sul, Instituto de Biociências, Departamento de Botânica, Av. Bento Gonçalves, 9500, Setor 4, prédio 43433, Agronomia. 91540-000. Porto Alegre, Rio Grande do Sul, Brasil.

E-mail: mrritter@terra.com.br

Marcelo Monge (4, 20)

Universidade Estadual de Campinas, Instituto de Biologia, Av. Monteiro Lobato, 970. 13083-970. Campinas, São Paulo, Brasil.

E-mail: marcelomonge@gmail.com

Maria Alves (21, 22, 24, 25, 26, 27)

Universidade Estadual de Feira de Santana, Km 03, BR 116. 44031-460. Feira de Santana, Bahia, Brasil.

E-mail: maria.alves1987@hotmail.com

Mariana A. Grossi (28)

Museo de La Plata, División Plantas Vasculares, Paseo del Bosque, s/n, 1900. La Plata, Argentina.

E-mail: grossi@fcnym.unlp.edu.ar

\section{Mariana Machado Saavedra (2)}

Universidade Federal do Rio de Janeiro, Instituto de Biologia, Departamento de Botânica, Avenida Carlos Chagas Filho 373, Cidade Universitária. 21941902. Rio de Janeiro, Rio de Janeiro, Brasil.

E-mail: mariana.saav@gmail.com

\section{Massimiliano Dematteis (14)}

Instituto de Botánica del Nordeste (UNNE-CONICET), Sargento Cabral 2131, Casilla de Correo 209, 3400. Corrientes, Argentina.

E-mail: mdematteis@arg.unne.edu.ar

Nádia Roque $(1,2,8,9,23)$

Universidade Federal da Bahia, Instituto de Biologia, Av. Ademar de Barros, s/n, Campus Universitário de Ondina40170-110. Salvador, Bahia, Brasil. E-mail: nadiaroque@gmail.com 
Polyana N. Soares (14)

Colégio Cenecista Dr. José Ferreira, Rua Felipe dos Santos, 286, Nossa Senhora da Abadia. 38025-140. Uberaba, Minas Gerais, Brasil.

E-mail: polyanansoares@gmail.com

Roberto L. Esteves $(14,29)$

Universidade do Estado do Rio de Janeiro, Departamento de Biologia Animal e Vegetal, Rua São Francisco Xavier, 524, Maracanã. 20550-900. Rio de Janeiro, Rio de Janeiro, Brasil.

E-mail: esteves.vr@uerj.br

\section{Rosângela Simão Bianchini (7)}

Instituto de Botânica, Núcleo de Pesquisa em Curadoria do Herbário, Caixa Postal 3005. 01061-970, São Paulo, São Paulo, Brasil.

E-mail: bianchiniibot@yahoo.com.br

\section{Silvana da Costa Ferreira (28)}

Universidade Federal de Viçosa, Instituto de Ciências Biológicas e da Saúde, Rodovia BR 354, Km 310, Campus Rio Paranaíba, Caixa Postal 22. Rio Paranaíba, Minas Gerais, Brasil.

E-mail: silvanacferreira@yahoo.com.br

\section{Vanessa Rivera (28)}

Universidade de Brasília, Instituto de Ciências Biológicas, Departamento de Botânica, Campus Darcy Ribeiro, Caixa Postal 04457. 70919-970. Brasília, Distrito Federal, Brasil.

E-mail: nessarivera@gmail.com

Vânia Gonçalves L. Esteves $(14,29)$

Universidade Federal do Rio de Janeiro, Museu Nacional, Departamento de Botânica, Quinta da Boa Vista, Horto Botânico, Laboratório de Palinologia, São Cristovão. 20940-040, Rio de Janeiro, Rio de Janeiro, Brasil.

E-mail: vsteves@acd.ufrj.br 


\title{
INTRODUÇÃO
}

\author{
हो? \\ Nádia Roque \\ Aristônio Magalhães Teles \\ Jimi Naoki Nakajima
}

Asterales é uma das ordens mais derivadas dentre as Eudicotiledôneas e inclui 11 famílias (APG 2016) e cerca de 26.870 espécies. A ordem é monofilética com base em dados moleculares e morfológicos, com destaque para a presença de pétalas valvares, presença de inulina (oligossacarídeo) como carboidrato de reserva e frequente mecanismo de polinização do tipo êmbolo (JUDD et al., 2009).

Dentre as hipóteses de parentesco na ordem, Asteraceae e Calyceraceae têm sido consideradas grupos irmãos (LUNDBERG, 2009; LUNDBERG; BREMER, 2003). Calyceraceae é uma família pequena (4 gêneros e aproximadamente 60 espécies) endêmica do sul da América do Sul e com várias similaridades morfológicas com Asteraceae, como as flores em capítulo circundadas por brácteas involucrais, ovário ínfero com um único óvulo e fruto do tipo cipsela com o cálice modificado e persistente. Contudo, há também dissimilaridades, e as mais notáveis são o estilete indiviso, glabro, estigma capitado e um óvulo apical pêndulo, além da ausência do arsenal químico encontrado em Asteraceae, como os poliacetilenos e lactonas sesquiterpênicas (HEALD, 2004).

Asteraceae Bercht. \& J. Presl é uma das maiores famílias de plantas e, segundo Bentham (1873), a mais distinta e também a mais natural entre as Angiospermas. Várias características morfológicas corroboram o seu monofiletismo; entre elas, a inflorescência em capítulo racemoso, anteras conatas, ovário ínfero, bicarpelar, com um óvulo de placentação basal e 
que se desenvolve em uma cipsela geralmente com pápus (BREMER, 1994; FUNK et al. 2009; JANSEN; PALMER, 1987).

A família está representada por numerosos gêneros (mais de 1.600) e cerca de 24 mil espécies, com distribuição cosmopolita e com maior abundância nas regiões temperadas e semiáridas dos trópicos e subtrópicos (FUNK et al. 2009b). Espécies de Asteraceae têm sido cultivadas pela sua importância econômica, principalmente relacionada às culturas alimentícias de folhas, caules e sementes para extração de óleo vegetal (SIMPSON, 2009). Dentre as espécies cultivadas, destacam-se: alface (Lactuca sativa L.), chicória (Cichorium intybus L.), escarola (Cichorium endivia L.), alcachofra (Cynara scolymus L.) e girassol (Helianthus annuus L.). Várias outras espécies são utilizadas na medicina, como o adoçante, extraído de Stevia rebaudiana (Bertoni) Bertoni, além de pomadas (Calendula officinalis L., Arnica montana L.) e chás, como a camomila, que se refere a várias espécies, incluindo Matricaria recutita $\mathrm{L}$. Dentre as bebidas mais famosas, destaca-se o absinto, um licor aromatizado com Artemisia absinthium L., que tem sido utilizada há milênios na Europa para superar a fragilidade corporal. (SIMPSON, 2009) Tanacetum cinerariifolium (Trev.) Sch. Bip. é cultivada pelo potencial inseticida e, finalmente, cerca de 20 espécies de Asteraceae são utilizadas como ornamentais; dentre elas, Chrysanthemum indicum L., Zinnia elegans Jacq., Gazania spp., Helianthus spp. e híbridos de Gerbera e Dahlia.

Nas duas últimas décadas, têm se observado mudanças expressivas na circunscrição e classificação em níveis hierárquicos superiores nas Asteraceae (BREMER, 1994, 1996; JANSEN; PALMER 1987; KIM; JANSEN, 1995; PANERO; FUNK, 2002, 2008). Em 2007, Kadereit e Jeffrey consideraram a família dividida em 2 grupos monofiléticos: um menor, composto pela subfamília Barnadesioideae, e um clado "não Barnadesioideae", dividido em 4 subfamílias (Mutisioideae, Carduoideae, Cichorioideae e Asteroideae) e 36 tribos.

Posteriormente, Panero e Funk (2002, 2008), Funk e colaboradores (2009) e Panero e colaboradores (2014), a partir da análise filogenética, utilizando diversos marcadores moleculares, reconheceram 13 subfamílias e 44 tribos. Mesmo parecendo um rearranjo extremo as Asteraceae passarem de 13 para 36 e, posteriormente, para 44 tribos, é interessante notar que a maioria das 13 tribos tradicionais (BENTHAM, 1873) é monofilética ou 
pode ser monofilética a partir de pequenas alterações (FUNK et al., 2009). Contudo, 2 tribos, Mutisieae (sensu CABRERA, 1977) e Heliantheae sensu lato, foram amplamente segregadas (PANERO; FUNK 2008; PANERO et al., 2014).

Dessa proposta, cabe destacar o clado Aliança Heliantheae (BALDWIN et al., 2002; PANERO; FUNK, 2002, 2008), cuja classificação foi apresentada por Panero (2007) e inclui 13 tribos, das quais 8 ocorrem no Brasil (Helenieae, Coreopsideae, Neurolaeneae, Tageteae, Bahieae, Heliantheae sensu stricto, Millerieae e Eupatorieae). Esse clado é o mais derivado na família e representa cerca de 5.500 espécies, que ocorrem principalmente na América (BALDWIN, 2009).

Segundo a classificação atual (BFG, 2015; FUNK et al. 2009), no Brasil ocorrem 27 tribos representadas por 2.013 espécies e 278 gêneros, distribuídos em todos os biomas, porém com maior diversidade nas formações campestres, como cerrado, campos rupestres e campos sulinos, e menos frequentes em áreas de mata atlântica, restinga, caatinga, brejos e florestas de altitude.

Mesmo com grandes avanços no entendimento das relações filogenéticas em Asteraceae, um dos grandes problemas enfrentados no Brasil se refere à falta de conhecimento acerca da riqueza dos gêneros e distribuição geográfica de boa parte das espécies. Portanto, nosso objetivo é divulgar e multiplicar o conhecimento sobre a diversidade das Asteraceae no país, oferecendo subsídios para que novos estudos com representantes da família possam ser conduzidos.

Asteraceae Bercht. \& J. Presl, Prir Rostlin 254, 1820.

Ervas anuais, bianuais ou perenes, arbustos, subarbustos, menos frequentemente árvores ou lianas, geralmente terrestres, raro epífitas ou aquáticas, algumas vezes suculentas; caule geralmente cilíndrico, raramente alado; ramos glabros, glabrescentes ou com indumento de tricomas tectores e/ou glandulares de vários tipos. Folhas em roseta, alternas, opostas, alterno-opostas, ou menos comumente verticiladas, simples, frequentemente lobadas ou pinatissectas, raro compostas, estípulas ausentes. Inflorescência em capítulo, capítulos solitários no ápice do pedúnculo 
floral (escapo) ou, geralmente, poucos a muitos capítulos em capitulescência cimosa, corimbiforme, espiciforme, paniculiforme, racemiforme, umbeliforme ou ainda agrupados em capitulescência de segunda ou terceira ordem, livres ou adnatos entre si (sincefalia de capítulos). Capítulo formado de flores sésseis, 1-500 ou mais por capítulo, circundado por um invólucro de brácteas, cilíndrico, hemisférico, turbinado ou globoso; caliculado ou ecaliculado; brácteas involucrais 1-muitas séries, persistentes, raro decíduas, imbricadas ou eximbricadas, cartáceas, coriáceas, escariosas, foliáceas, membranáceas ou papiráceas, hialinas ou opacas, alvas, amarelas, verdes, castanhas ou vináceas, face adaxial glabra ou variavelmente indumentada; receptáculo plano, côncavo, convexo ou cônico, paleáceo (páleas, persistentes ou caducas, subentendendo algumas ou todas as flores, planas ou conduplicadas) ou epaleáceo, ciliado, escamiforme, piloso ou glabro e, então, liso, areolado com aréolas poligonais ou alveolado, com depressões nas quais as flores são inseridas. Capítulos homógamos (flores com arranjos sexuais iguais) e discoides (flores com apenas um tipo de corola, seja tubular, tubular-filiforme, bilabiada ou ligulada) e capítulos heterógamos (flores com arranjos sexuais distintos), como os capítulos radiados (flores com 2 tipos de corola, liguliforme na margem e tubular no centro) e capítulos disciformes (flores com 2 ou 3 tipos de corola, geralmente com flores externas pistiladas e com corola tubular-filiforme, e as internas bissexuais ou apenas funcionalmente estaminadas e com corola tubular). Flores bissexuais ou unissexuais (perfeitamente unissexuais ou funcionalmente unissexuais por atrofia de um dos órgãos sexuais), estéreis (androceu e gineceu estéreis) ou neutras (sem androceu e gineceu). Flores gamopétalas, zigomorfas e normalmente actinomorfas (situadas no capítulo em 1-várias séries), compostas de tubo basal e porção superior bilateral (limbo): corola liguliforme (limbo expandido abaxialmente com 2-3 lobos apicais, geralmente pistilada, neutra ou estéril), corola ligulada (limbo expandido abaxialmente com 5 lobos apicais, bissexual), corola bilabiada (limbo com 3 lobos abaxiais e 2 lobos adaxiais, bissexual ou unissexual), corola pseudobilabiada (limbo com 3-4 lobos abaxiais e 1 lobo adaxial, bissexual ou unissexual) e corola sub-bilabiada (limbo com 3 lobos abaxiais e 1 lobo adaxial, pistilada); ou flores gamopétalas, actinomorfas, normalmente situadas na margem ou centro do capítulo, 1-muitas séries, corola tubular 5-lobada, bissexuais, 
raramente unissexuais, ou tubular-filiforme, lobos reduzidos, unissexuais (pistiladas). Androceu com 5 estames, alternipétalos, epipétalos, filetes livres, geralmente células apicais com paredes espessadas formando o colar da antera; anteras conatas (sinânteras) circundando o estilete, rimosas, introrsas, oblongas, amareladas, negras, avermelhadas ou arroxeadas, apêndice do conectivo apical ausente ou proeminente, agudo, apiculado, obtuso, bidentado ou retuso, base truncada, cordiforme, sagitada ou com apêndices basais caudiformes estéreis (anteras caudadas) e/ou tecido esporogênico alongado abaixo da inserção do filete (anteras calcaradas). Gineceu sincárpico, bicarpelar, ovário ínfero, unilocular, 1 óvulo, placentação basal, anátropo, tenuinucelado, estilete filiforme, 2-ramificado (raro 3 ou indiviso), ereto, recurvado (revoluto, divergente) ou pronado (curvado, convergente), com superfície de papilas estigmáticas interna contínua ou em 2 linhas paralelas, marginais (Asteroideae), porção apical fértil ou apêndices distais com papilas não estigmáticas (estéreis), comumente agudo, subulado, obtuso, truncado, glabro, papiloso, piloso, penicelado, tricomas coletores, quando presentes, restritos à face externa dos ramos, prolongando-se ou não abaixo do ponto de bifurcação, base do estilete cilíndrica ou dilatada, glabra ou pilosa, geralmente imersa em um disco nectarífero (estilopódio) localizado no ápice do ovário. Fruto cipsela, cilíndrica, obcônica, turbinada, fusiforme, menos comumente achatada, alada ou sem alas, ápice rostrado ou truncado, frequentemente castanha ou negra, glabra, tomentosa, serícea, pubescente, base truncada ou estipitada; área de abscisão circundada por um carpopódio, distinguido pela forma de suas células e textura da sua superfície, indistinto a proeminente, simétrico, bilateral, decorrente nas costelas ou não, ou ausente. Cálice representado por um pápus formado por 1(2)-muitas séries de cerdas (cerdoso, barbelado, plumoso), escamas, páleas, aristas, simples (todos os elementos iguais) ou duplo (série mais externa distinta da série mais interna), isomórfico (pápus igual em todas as flores) ou dimórfico (pápus das flores externas diferente do das flores internas), persistente - ou, pelo menos, as séries mais internas decíduas - ou completamente ausente, esbranquiçado, ferrugíneo, estramíneo, róseo, avermelhado, alaranjado ou purpúreo. Sementes sem endosperma, embrião reto. 


\section{Chave para identificação das tribos de Asteraceae no Brasil, com base em Barroso et al. (1991), Kadereit e Jeffrey (2007) e Funk e colaboradores (2009)}

1. Árvores ou arbustos comumente com espinhos axilares, raramente ervas (Schlechtendalia); lâmina foliar e brácteas involucrais com ápice mucronado ou espinescente; presença de corola pseudobilabiada (4+1), corola e cipselas com tricomas "barnadesioides" (tricomas tricelulares, unisseriados, com 1 célula apical alongada) Barnadesieae 1'. Árvores, arbustos, subarbustos, ervas ou trepadeiras sem espinhos axilares; lâmina foliar e brácteas involucrais geralmente com ápice inerme e, se espinescente, latescente em Cichorieae ou com estilete com uma coroa de tricomas na sua região mediana em Cardueae; ausência de corola pseudobilabiada (4+1), corola e cipsela glabras ou com indumento variado, mas não tricomas "barnadesioides"

2. Capítulescência formada por capítulos radiados (1-2 flores com corola liguliforme) e capítulos discoides Tageteae 2'. Capitulescência contendo apenas um único tipo de capítulo (radiado, disciforme ou discoide) 3

3. Capítulos discoides (flores com arranjos sexuais iguais e apenas um único tipo de corola, seja tubular, tubular-filiforme, bilabiada ou ligulada) (Figura 1C).

3'. Capítulos radiados, com uma ou mais flores do raio, pistiladas ou neutras, com corola liguliforme (limbo inteiro a 2-4-lobado), bilabiada (limbo 3+2 lobado), pseudobilabiada (4+1) ou sub-bilabiadas (3+1), às vezes 1-3 flores em Delilia e Schkuhria, e flores bissexuais ou funcionalmente estaminadas, localizadas na região central (Figura 1A); ou capítulos disciformes (pelo menos, com 2 tipos de flores não liguliformes, geralmente com uma a mais séries de flores pistiladas, neutras ou estéreis, com corola tubular-filiforme, e flores bissexuais ou funcionalmente estaminadas com corola tubulosa na região central) (Figura 1B) 26

4. Capítulos com todas as flores bissexuais ....................................................... 5

4'. Capítulos com todas as flores unissexuais ................................................ 24 
5. Ramos do estilete subulados ou claviformes, agudos ou obtusos, papilosos ou pilosos e, nesse caso, a pilosidade prolongada abaixo do ponto de bifurcação.

5'. Ramos do estilete obtusos, truncados, triangulares no ápice, com ou sem pilosidade localizada, pilosidade não prolongada abaixo do ponto de bifurcação. 8

6. Flores com corola ligulada, zigomorfa (limbo da corola com 5 lobos apicais)

Cichorieae 6'. Flores com corola tubular, actinomorfa (limbo com 5 lobos apicais), bilabiada, zigomorfa (limbo da corola com 3 lobos abaxiais e 2 lobos adaxiais) ou sub-bilabiada, zigomorfa (limbo com 3 lobos abaxiais e 1 lobo adaxial)

7. Anteras calcaradas (Figura 7G); ramos do estilete agudos, pilosos; cipselas sem fitomelanina; pápus geralmente duplo (série mais externa distinta da séria mais interna) Vernonieae 7'. Anteras ecalcaradas (Figura 23C); ramos do estilete obtusos, papilosos; cipselas geralmente com fitomelanina (enegrecidas); pápus geralmente simples

Eupatorieae

8. Ramos do estilete cilíndricos, clavados (Figuras 22H,K) ou capitados no ápice, papilosos

Eupatorieae

8'. Ramos do estilete obtusos, agudos, truncados (Figura 1M) ou triangulares, glabros ou com pilosidade no ápice

9. Invólucro unisseriado

9'. Invólucro 2-multisseriado 13

10. Capitulescência de capítulos agrupados e subentendidos por brácteas foliáceas (Figura 20A); capítulos unifloros (Figura 20B) Heliantheae 10'. Capitulescência de capítulos não agrupados e nem subentendidos por brácteas foliáceas; capítulos com duas ou mais flores

11. Folhas e brácteas involucrais com canais secretores formando manchas escuras alongadas Tageteae 11'. Folhas e brácteas involucrais sem canais secretores formando manchas escuras alongadas. 
12. Capítulo sem calículo; flores com corola bilabiada, zigomorfa (Figura $1 \mathrm{M})$ Nassauvieae

12'. Capítulo geralmente com calículo; flores com corola tubular, actinomorfa Senecioneae

13. Planta com projeções espinescentes nas partes aéreas (folhas, caule e brácteas involucrais); estilete com uma coroa de tricomas na sua região mediana Cardueae 13'. Plantas inermes; estilete glabro na sua porção mediana 14

14. Flores com corola bilabiada, zigomorfa (limbo com 3 lobos abaxiais e 2 lobos adaxiais) (Figura 1M) 15 14'. Flores com corola tubular, actinomorfa (limbo 4-5-lobado) 16

15. Ramos do estilete com ápice truncado, penicelado Nassauvieae 15'. Ramos do estilete com ápice obtuso ou agudo, glabro ou dorsalmente rugoso Stifftieae

16. Capítulos 1-(-5) flores; estilete distintamente entumecido abaixo da bifurcação (Figura 9F) Moquineae 16’. Capítulos 7-300 flores; estilete cilíndrico abaixo da bifurcação 17

17. Ramos do estilete acuminados, triangulares, truncados, lanceolados com tricomas ou papilas apenas no ápice; anteras ecaudadas 18 17'. Ramos do estilete arredondados, obtusos, glabros ou com papilas; anteras caudadas

18. Cipselas sem fitomelanina (sem coloração enegrecida); pápus de páleas aristadas Helenieae 18'. Cipselas geralmente com fitomelanina (enegrecidas); pápus de páleas sem aristas, coroniforme, aristado ou ausente

19. Brácteas involucrais externas diferentes das internas na forma e na cor, sendo só as da segunda série com estrias castanho-alaranjadas

Coreopsideae

19'. Brácteas involucrais todas iguais na forma e na cor; se diferentes em forma, sem estrias ou com estrias de outras cores em todas as séries ..... 20 
20. Anteras de coloração amarela; pápus de páleas ou escamas, raramente coroniforme 21

20'. Anteras de coloração enegrecida; pápus coroniforme, cerdoso, aristado ou ausente.

Heliantheae

21. Plantas não suculentas; brácteas involucrais escariosas, estriadas; cipselas 4-costadas. Neurolaeneae 21'. Plantas suculentas; brácteas involucrais crassas, não estriadas; cipselas conspicuamente 9-15-costadas Tageteae

22. Receptáculo comumente paleáceo; ramos do estilete com papilas acima e/ou abaixo da bifurcação; pápus paleáceo Wunderlichieae 22'. Receptáculo epaleáceo; ramos do estilete glabros (Figura 4G); pápus cerdoso 23

23. Capitulescência corimbiforme ou paniculiforme, geralmente pluricéfala; apêndice do conectivo da antera apiculado; pápus 1-3-seriado (Figuras 4H-I), 25-90 elementos, estramíneo Gochnatieae 23'. Capítulos em cimeiras axilares, geralmente paucicéfalos ou solitários; apêndice do conectivo da antera agudo; pápus (3-)4-5-seriado, 100-150 elementos, avermelhado, róseo ou alaranjado Stifftieae 24. Plantas monoicas; invólucro dos capítulos estaminados com uma série de brácteas involucrais livres ou conatas; invólucro dos capítulos pistilados com brácteas involucrais completamente fundidas (adnatas às flores e posteriormente fusionadas às cipselas); com uma a 2 flores desprovidas de corola; pápus ausente. Heliantheae 24'. Plantas dioicas; invólucro dos capítulos estaminados e pistilados com brácteas involucrais dispostas em várias séries, livres entre si; flores estaminadas e pistiladas com corola; pápus geralmente presente 25

25. Anteras calcaradas, caudadas (Figura 4J); ramos do estilete obtusos ou agudos, glabros Tarchonantheae 25'. Anteras ecalcaradas, ecaudadas; ramos do estilete triangulares ou lanceolados, com tricomas na face dorsal Astereae 
26. Folhas e brácteas involucrais com canais secretores formando manchas escuras alongadas Tageteae

26'. Folhas e brácteas involucrais sem canais secretores formando manchas escuras alongadas.

27. Plantas aromáticas, folhas variavelmente pinatissectas, flores marginais pistiladas, podendo a corola ser reduzida ou ausente Anthemideae 27'. Sem o conjunto das características acima 28

28. Brácteas involucrais papiráceas, geralmente hialinas e frequentemente coloridas (alvas ou amarelas) Gnaphalieae 28'. Brácteas involucrais cartáceas ou membranáceas, opacas, geralmente verdes, castanhas, raro vináceas, alvas ou creme 29

29. Capítulos disciformes 30

29'. Capítulos radiados 33

30. Flores marginais pistiladas, dispostas em uma ou mais séries e flores do disco, bissexuais ou funcionalmente estaminadas, em número menor que o das flores pistiladas; cipselas sem fitomelanina 31 30' Flores marginais pistiladas 1-9 e flores do disco bissexuais ou funcionalmente estaminadas, em número igual ou maior que as pistiladas; cipselas com fitomelanina. 32

31. Brácteas providas de região basal mais engrossada (estereoma); anteras caudadas; flores do disco com ramos do estilete pilosos abaixo do ponto de bifurcação (exceto Pterocaulon) Inuleae 31'. Brácteas involucrais não providas de estereoma; anteras ecaudadas; flores do disco com ramos do estilete glabros abaixo do ponto de bifurcação Astereae

32. Receptáculo convexo a cônico; páleas geralmente espatuladas

Millerieae

32'. Receptáculo plano a levemente convexo; páleas de outros formatos ou ausentes Heliantheae

33. Capítulo com 1-3 flores do raio. 34

33. Capítulo com mais de 3 flores do raio. 35 
34. Cipsela costada; pápus presente Bahieae

34'. Cipsela sem costas; pápus ausente. Heliantheae

35. Capítulos com 3 tipos de flores (flores da margem com corola liguliforme ou sub-bilabiada $(3+1)$, flores intermediárias com corola tubuloso-filiforme e flores do disco com corola tubuloso-bilabiada) Mutisieae 35'. Capítulos com 2 tipos de flores (flores da margem e flores do disco) .....

36. Flores do raio com corola bilabiada ou liguliforme; cipselas sem fitomelanina (sem coloração enegrecida) 37 36. Flores do raio com corola liguliforme; cipselas geralmente com fitomelanina (enegrecidas) e, se sem fitomelanina, com pápus de páleas aristadas 41

37. Ramos do estilete curto bifurcados, obtusos ou arredondados, glabros (Figura 4G) ou escassamente papilosos na face dorsal 38 37'. Ramos do estilete divididos em 2 ramos mais ou menos profundos, agudos, triangulares, lanceoladas ou truncados, pilosos no ápice e na face dorsal (Figura 13A) Senecioneae

38. Ramos do estilete glabros 39

38'. Ramos do estilete papilosos na face dorsal 40

39. Lâmina foliar trinérvea; cipselas 10-costadas; pápus 4-seriado, cerdas púrpura. Hyalideae 39'. Lâmina foliar peninérvea; cipselas 5-costadas; pápus 1-3-seriado, cerdas estramíneas Gochnatieae

40. Arbustos, raramente ervas (Onoseris); flores do disco com corola tubular, actinomorfa; cipselas truncadas; pápus 2-4-seriado, dimórfico

Onoserideae 40'. Ervas, trepadeiras; flores do disco com corola bilabiada, zigomorfa; cipselas truncadas ou rostradas no ápice; pápus geralmente unisseriado, isomórfico Mutisieae

41. Receptáculo epaleáceo; pápus de páleas aristadas Helenieae 41'. Receptáculo frequentemente paleáceo; pápus de páleas sem aristas, coroniforme, aristado, cerdoso, plumoso ou ausente 42 
42. Pápus de páleas ou escamas livres 43

42'. Pápus coroniforme, aristado, cerdoso, plumoso ou ausente

43. Capítulos com todas as flores com corolas da mesma cor; anteras amarelas Neurolaeneae 43'. Capítulos com flores do raio com corolas de cor diferente das corolas das flores do disco; anteras enegrecidas. Millerieae

44. Capítulos axilares, solitários e sésseis Neurolaeneae 44'. Capítulos terminais ou axilares, solitários ou formando capitulescências, sésseis ou pedunculados, nunca com o conjunto de características mencionadas no passo anterior 45

45. Páleas do receptáculo geralmente planas, não envolvendo as cipselas das flores do disco; ramos do estilete com papilas curtas, sem formar tufo apical, ou ausentes. 46

45'. Páleas do receptáculo conduplicadas, envolvendo as cipselas das flores do disco; ramos do estilete geralmente com um tufo apical de papilas

Heliantheae

46. Brácteas involucrais externas diferentes das internas na forma e cor, sendo as da segunda série com estrias castanho-alaranjadas; pápus de 2-8 aristas, lisas ou com cerdas antrorsas ou retrorsas, raramente com escamas, ou pápus ausente. Coreopsideae 46'. Brácteas involucrais todas iguais na forma e cor, se diferentes na forma, estrias ausentes ou com outras cores; pápus barbelado, plumoso ou ausente Millerieae 


\section{Referências}

ANGIOSPERM PHYLOGENY GROUP. An update of the Angiosperm Phylogeny Group classification for the orders and families of flowering plants: APG IV. Botanical Journal of the Linnean Society, London, v. 181, n. 1 p.1-20, 2016.

BALDWIN, B.G.; WESSA, B. L. ; PANERO, J. L. Nuclear rDNA evidence for major lineages of helenioid Heliantheae (Compositae). Systematic Botany, Kent, v. 27, p. 161-198, 2002.

BARROSO, G. M. et al. Sistemática de angiospermas do Brasil. Viçosa: UFV, 1991. v. 3.

BENTHAM, G. Notes on the classification, history and geographical distribution of Compositae. Botanical Journal of the Linnean Society, London, v. 13 , n. 70/72, p. 335-577, 1873.

BRAZIL FLORA GROUP -BFG. Growing knowledge: an overview of seed plant diversity in Brazil. Rodriguésia, Rio de Janeiro, v. 66, n. 4, p. 10851113, 2015.

BREMER, K. Asteraceae: cladistics and classification. Portland: Timber Press, 1994.

BREMER, K. Major clades and grades of the Asteraceae. In: HIND, D. J. N.; BEENTJE, H. J. (Ed.). Compositae: Proceedings of the International Asteraceae Conference 1994. Kew: Royal Botanic Gardens, 1996. v. 1. p. 1-7.

CABRERA, A. L. Mutisieae: systematic review. In: HEYWOOD, V. H.; HARBORNE, J. B.; TURNER, B. L. (Ed.). The Biology and Chemistry of the Compositae. London: Academic Press, 1977. v. 2. p. 1039-1066.

CASSINI, H. Suit du Sixième mémoire sur la famille des Synanthérées, contenant les caractères des tribus. Journal de Physique, de Chimie, d'Histoire Naturelle et des Arts, Paris, t. 88, p. 150-163, 1819. 
FUNK, V. A. et al. Everywhere but Antarctica: using a supertree to understand the diversity and distribution of the Compositae. Biologiske Skrifter, Copenhagen, n. 55, p. 343-374, 2005 .

FUNK, V. A. et al. Compositae metatrees: the next generation. In: FUNK, V. A. et al. (Ed.). Systematics, Evolution and Biogeography of Compositae. Vienna: IAPT, 2009. Chap. 44, p. 747-777.

FUNK, V. A. et al. (Ed.). Systematics, Evolution and Biogeography of Compositae. Vienna: IAPT, 2009.

HEALD, S. V. Calyceraceae. In: SMITH, N. et al. (Ed.). Flowering Plants of the Neotropics. Princeton: Princeton University Press, 2004. p. 77-78.

JANSEN, R. K.; PALMER, J. D. A chloroplast DNA inversion marks an ancient evolutionary split in the sunflower family (Asteraceae). Proceedings of the National Academy of Sciences, Washington, v. 84, n. 16, p. 5818-5822, 1987.

JUDD, W.A. et al. Sistemática vegetal: um enfoque filogenético. 3. ed. Porto Alegre: Artmed, 2009.

KADEREIT, J. W.; JEFFREY, C. Compositae. In: KADEREIT, J.W.; JEFFREY, C. (Ed.). The Families and Genera of Vascular Plant: v. VIII: Flowering Plants Eudicots: Asterales. Berlin: Springer-Verlag, 2007. p. 61-588.

KIM, K. J.; JANSEN, R. K. ndhF sequence evolution and the major clades in the sunflower family. Proceedings of the National academy of Science of the United States of America, Washington, v. 92, n. 22, p. 10379-10383, 1995.

LUNDBERG, J. Asteraceae and relationships within Asterales. In: FUNK, V. A et al. Systematics, Evolution and Biogeography of Compositae. Vienna: IAPT, 2009. Chap. 10, p. 157-169.

LUNDBERG, J.; BREMER, K. A phylogenetic study of the order Asterales using one morphological and three molecular data sets. International Journal of Plant Science, Chicago, v. 164, n. 4, p. 553-578, 2003.

PANERO, J. L.; FUNK, V. A. Toward a phylogenetic subfamilial classification for the Compositae (Asteraceae). Proceedings of the Biological Society of Washington, Washington, v. 115, n. 4, p. 909-922, 2002. 
PANERO, J. L.; FUNK, V. A. The value of sampling anomalous taxa in phylogenetic studies: major clades of the Compositae revealed. Molecular Phylogenetics and Evolution, Orlando, v. 47, n. 2, p. 757-782, 2008.

PANERO, J. J. et al. Resolution of deep nodes yield an improved backbone phylogeny and a new basal lineage to study early evolution of Asteraceae. Molecular Phylogenetic and Evolution, Orlando, v. 80, p. 43-53, 2014.

SIMPSON, B.B. Economic importance of Compositae. In: FUNK, V. A et al. Systematics, Evolution and Biogeography of Compositae. Vienna: IAPT, 2009. Chap. 3. p. 45-58. 

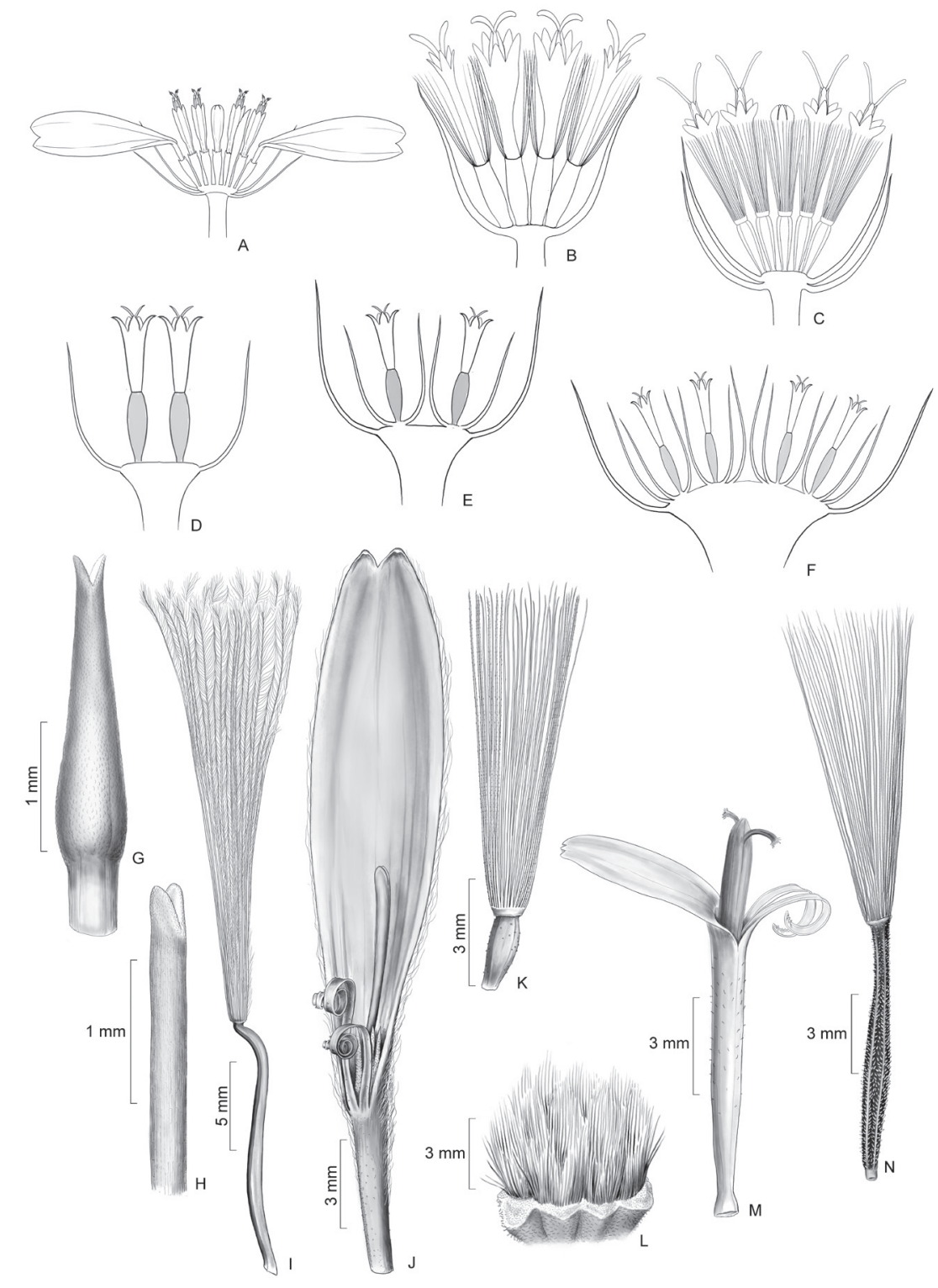

$\mathrm{F}$

Figura 1. A. Capítulo radiado de Aspilia subalpestris Baker; B. Capítulo disciforme de Chaptalia integerrima (Vell.) Burkart; C. Capítulo discoide de Conocliniopsis prasiifolia (DC.) R.M. King \& H. Rob.; D. Capítulo de $1^{\mathrm{a}}$ ordem (geralmente organizado em capitulescência); E. Capítulos de $2^{\mathrm{a}}$ ordem (livres ou sincefalia); F. Capítulos de $3^{\text {a }}$ ordem (ou sincefalia). Barnadesieae. G. Ápice do estilete de Fulcaldea stuessyi Roque \& V.A. Funk; H. Ápice do estilete de Dasyphyllum donianum (Gardner) Cabrera. Mutisieae. I. Cipsela e pápus plumoso de Mutisia coccinea A. St. Hill; J-K. Trichocline catharinensis Cabrera var. discolor Cabrera: J. Corola, estaminódios e estilete da flor do raio; K. cipsela e pápus. Nassauvineae. L-N. Trixis glutinosa D. Don: L. receptáculo piloso; M. corola bilabiada, estames e ramos do estilete truncados, penicilados; N. Cipsela e pápus. 


\title{
TRIBO BARNADESIEAE D. DON
}

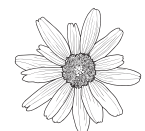 \\ Mariana Machado Saavedra \\ Nádia Roque
}

Barnadesieae é um grupo monofilético exclusivo da América do Sul, com centro de diversidade nos Andes, e que tem despertado grande interesse devido a seu posicionamento basal nas Asteraceae (BREMER, 1994, 1996).

A tribo foi descrita por David Don (1830) como uma das 9 tribos de Asteraceae, mas logo após passou a ser considerada uma subtribo (Barnadesiineae) de Mutisieae (BENTHAM, 1873), classificação esta mantida por Cabrera $(1961,1977)$. A tribo Barnadesieae foi reestabelecida após estudos de biologia molecular (JANSEN; PALMER 1987, JANSEN et al., 1991) indicarem que todos os membros das Asteraceae possuíam uma inversão no DNA do cloroplasto, com exceção da subtribo Barnadesiinae, até então subordinada à tribo Mutisieae (CABRERA, 1977). Com base nesses estudos, Bremer \& Jansen (1992) elevaram Barnadesiinae ao status de subfamília, Barnadesioideae (Benth. \& Hook. f.) K. Bremer \& R.K. Jansen, abrigando, atualmente, 83 espécies pertencentes a 9 gêneros (STUESSY; URTUBEY, 2007; SAAVEDRA, 2011).

A tribo pode ser reconhecida pelo hábito arbóreo ou arbustivo com espinhos axilares pareados ou em fascículos, raramente ervas (Schlechtendalia); lâmina foliar e brácteas involucrais com ápice mucronado ou espinescente; corola (externa, tubo e lacínias) e cipsela com tricomas "barnadesioides" (tricoma tricelular, unisseriado, com uma célula apical alongada); pápus plumoso, raramente com escamas (Schlechtendalia), barbelado ou setoso (Barnadesia). 
A tribo é composta por 3 grandes gêneros, Dasyphyllum Kunth (31 spp.), Chuquiraga Juss. (23 spp.) e Barnadesia Mutis ex L.f. (19 spp.), sendo os outros 6 representados por até 3 espécies: Arnaldoa Cabrera, com 3 espécies; Doniophyton Wedd. e Fulcaldea Poir. ex Lam., com 2 espécies cada; e Duseniella K. Schum., Huarpea Cabrera e Schlechtendalia Less., monoespecíficos. (FUNK; ROQUE, 2011; SAAVEDRA, 2011; STUESSY; URTUBEY 2007; STUESSY; URTUBEY; GRUENSTAEUDL, 2009)

\section{Descrição}

Árvores, arbustos, lianas ou ervas, monoicos ou ginodioicos; ramos eretos ou decumbentes, espinhos axilares geralmente presentes. Folhas simples, alternas, fasciculadas ou verticiladas, algumas vezes, as basais rosuladas, sésseis a pecioladas, lâmina foliar com margem inteira, glabra, glabrescente ou tomentosa, ápice frequentemente espinescente, nervação acródroma, actinódroma ou paralelódroma. Capitulescência umbeliforme, paniculiforme ou capítulos geminados ou solitários e terminais; receptáculo plano ou côncavo, epaleáceo ou com páleas esparsas ou geralmente piloso. Capítulos discoides ou radiados; invólucro campanulado, infundibuliforme, turbinado ou cilíndrico; brácteas involucrais 5-12 séries, imbricadas, desiguais, ápice apiculado até aristado. Flores 1 a numerosas, brancas, amareladas, rosa, vermelhas, lilás, flores do raio 8-13 (Barnadesia), corola pseudobilabiada $(4+1)$ ou bilabiada $(3+2)$, bissexuadas ou funcionalmente pistiladas, as do disco corola tubular ou ligulada, tubo da corola glabro, glabrescente ou seríceo; estames com apêndice do conectivo da antera inteiro ou bilobado, base da antera calcarada, caudada, base sagitada ou decorrente, filetes livres ou raramente unidos entre si (Barnadesia), inseridos próximo à base ou ápice do tubo da corola; estilete bilobado ou curtamente bífido, ramos do estilete papilosos, glabros, raro pilosos, papilas estendendo-se abaixo do ponto de bifurcação. Cipselas isomórficas, fusiformes ou heteromórficas, cilíndricas nas flores do raio e obcônicas nas flores do disco, seríceas ou tomentosas; pápus plumoso, raramente escamiforme, barbelado ou setoso, em Barnadesia, pápus das flores do raio plumoso e do disco com cerdas lineares, rígidas, acuminadas, unidas na base, eretas ou revolutas 
ao secar, unisseriadas, alvas ou estramíneas. Tricomas barnadesioides, não ramificados, 3-celulares, na corola, cipsela e pápus.

No Brasil, Barnadesieae está representada por 4 gêneros: Barnadesia, com uma espécie não endêmica do Brasil, ocorrendo no Centro-Oeste e Sudeste, nos domínios do cerrado e mata atlântica (Figura 2A); Dasyphyllum, com 15 espécies, das quais 11 são endêmicas, com distribuição extra-amazônica (Figuras 2B-C); Fulcaldea, com 1 espécie, endêmica do Brasil, na Chapada Diamantina, Bahia; e Schlechtendalia, com 1 espécie não endêmica do Brasil e distribuição nos pampas do Rio Grande do Sul (Figura 2D).

\section{Chave de identificação para os gêneros de Barnadesieae no Brasil}

1. Ervas; folhas rosuladas na base e opostas ao longo do caule, 11-nervada, nervação paralelódroma Schlechtendalia 1'. Árvores, arbustos ou lianas; folhas alternas, fasciculadas ou verticiladas, 3-7 nervadas, nervação acródroma ou actinódroma. 2

2. Capítulo com 1 flor; estilete distintamente dilatado e papiloso abaixo da bifurcação (Figura 1G) Fulcaldea 2'. Capítulo com mais de 1 flor; estilete cilíndrico e glabro abaixo da bifurcação (Figura 1H) . 3

3. Capítulos radiados; as flores radiais com corola púrpura ou rósea (Figura 2A); anteras com apêndice apical inteiro; pápus heteromórfico

Barnadesia

3'. Capítulos discoides; flores com corola alva ou creme (Figuras 2B-C); anteras com apêndice apical bilobado; pápus isomórfico Dasyphyllum

\section{Literatura recomendada}

BENTHAM, G. Compositae. In: BENTHAM, G.; HOOKER, J. D. (Ed.). Genera Plantarum. London: Reeve, 1873, v. 2, n. 1, p. 163-533. 
BREMER, K. Asteraceae: cladistics and classification. Portland: Timber Press, 1994.

BREMER, K. Major clades and grades of the Asteraceae. In: HIND, D. J. N.; BEENTJE, H. J. (Ed.). Compositae systematic: proceedings of the international Compositae conference 1994. Kew: Royal Botanic Gardens, 1996. v. 1, p. 1-7.

BREMER, K.; JANSEN, R. K. A new subfamily of the Asteraceae. Annals of the Missouri Botanical Garden, Saint Louis, v. 79, p. 414-415, 1992.

CABRERA, A. L. Revisión del género Dasyphyllum (Compositae). Revista del Museo de La Plata, Seccion Botanica, La Plata, v. 9, n. 38, p. 21-100, 1959.

CABRERA, A. L. Compuestas Argentinas: clave para la determinación de los géneros. Revista del Museo Argentino de Ciencias Naturales "Bernardino Rivadavia". Buenos Aires, v. 2, n. 5, p. 291-362, 1961.

CABRERA, A. L. Mutisieae: systematic review. In: HEYWOOD, V. H.; HARBORNE, J. B.; TURNER, B. L. (Ed.). The Biology and Chemistry of the Compositae. London: Academic Press, 1977. v. 2. p. 1039-1066.

DON, D. Descriptions of new genera and species of the Class Compositae belonging to the Floras of Peru, Mexico, and Chile. The Transactions of the Linnean Society of London, London, v. 16, n. 2, p. 169-303, 1830.

FUNK, V. A.; ROQUE, N. The monotypic Andean genus Fulcaldea (Compositae, Barnadesioideae) gains a new species from northeastern Brazil. Taxon, Utrecht, v. 60, n. 4, p. 1095-1103, 2011.

JANSEN, R. K., et al. Chloroplast DNA variation in the Asteraceae: phylogenetic and evolutionary implications. In: SOLTIS, D.; SOLTIS, P; DOYLE, J. (Ed.). Molecular Systematics of Plants. New York: Chapman \& Hall, 1991. p. 252-279.

JANSEN, R. K.; PALMER, J. D. A chloroplast DNA inversion marks an ancient evolutionary split in the sunflower family (Asteraceae). Proceedings of the National Academy of Sciences, Washington, v. 84, n. 16, p. 5818-5822, 1987. 
SAAVEDRA, M. M. Sistemática de Dasyphyllum (Asteraceae). 2011. 247 f. Tese (Doutorado em Botânica) - Instituto de Pesquisas Jardim Botânico do Rio de Janeiro, Escola Nacional de Botânica Tropical, Rio de Janeiro, 2011. STUESSY, T. F.; URTUBEY, E. Tribe Barnadesieae. In: KADEREIT, J.W.; JEFFREY, C. (Ed.). The Families and Genera of Vascular Plant: v. VIII: Flowering Plants Eudicots: Asterales. Berlin: Springer-Verlag, 2007. p. 87-90.

STUESSY, T. F.; SANG, T.; DEVORE, M. L. Phylogeny and biogeography of the subfamily Barnadesioideae with implications for early evolution of the Compositae. In: HIND, D. J. N.; BEENTJE, H. J. (Ed.). Compositae systematic: proceedings of the international Compositae conference 1994. Kew: Royal Botanic Gardens, 1996. v. 1. p. 463-490.

STUESSY, T. F.; URTUBEY, E.; GRUENSTAEUDL, M. Barnadesieae (Barnadesioideae). In: FUNK, V. A et al. Systematics, Evolution and Biogeography of Compositae. Vienna: IAPT, 2009. p. 215-228.

URTUBEY, E. Revisión del género Barnadesia (Asteraceae: Barnadesioideae, Barnadesieae). Annals of the Missouri Botanical Garden, Saint Louis, v. 86, p. 57-117, 1999. 


\section{TRIBO MUTISIEAE CASS.}

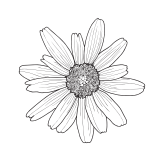

Eduardo Pasini

A compreensão da tribo Mutisieae s.l. é essencial para elucidar a radiação evolutiva e as relações de parentesco entre as Asteraceae basais (FUNK et al., 2009), além de proporcionar o entendimento de gêneros muito peculiares e isolados (BREMER, 1994).

Cabrera (1977) realizou o estudo mais completo e global envolvendo a tribo Mutisieae, cuja classificação serviu de subsídio até a descoberta da subtribo Barnadesiinae Benth. \& Hook como grupo irmão para o resto da família (JANSEN; PALMER, 1987).

Estudos revisivos e cladísticos, como de Cabrera (1977), Hansen (1991), Karis, Kallersjoån e Bremer (1992), Bremer e Jansen 1992 e Bremer (1994, 1996), invariavelmente, concluíram que a tribo Mutisieae (sensu Cabrera) era parafilética e necessitava ser desmembrada. Contudo, esses estudos não apresentaram um consenso para a obtenção de uma classificação estável para o grupo, de modo que conclusões sobre a sua circunscrição eram ainda contraditórias.

Recentemente, análises com base em filogenias moleculares, tais como as de Panero e Funk (2002, 2007, 2008) e Funk e colaboradores (2009), propuseram a divisão das Mutisieae em 13 tribos. Algumas dessas tribos são morfologicamente distintas e reconhecidas como clados (Barnadesieae, Nassauvieae, Onoserideae, Mutisieae, Gochnatieae, Hecastocleideae, Tarchonantheae, Oldenburgieae, Dicomeae e Pertyeae), enquanto outras (Stifftieae, Hyalideae, Wunderlichieae) e suas subfamílias (Stifftioideae, Wunderlichioideae) não são uniformemente aceitas (FUNK et al., 2014; KATINAS et al., 2008, ORTIZ et al., 2009). 
Segundo a classificação proposta por Funk e colaboradores (2009), Mutisieae s. str. compreende 14 gêneros e aproximadamente 200 espécies, com distribuição predominante na América do Sul, mas com representantes na América do Norte, América Central, Ásia, África e Austrália. A tribo pode ser reconhecida pelos hábitos herbáceos, arbustivos ou trepadeiras, com grande variação na corola (bilabiada, sub-bilabiada, tubular, filiforme, ligulada) e, algumas vezes, as corolas marginais são conspicuamente expandidas e muito vistosas (vermelhas, amarelas, amarelo-alaranjadas, alaranjadas, brancas ou lilás). As anteras apresentam apêndices basais caudados, estilete bilobado a bífido, com ápices dos ramos arredondados e papilosos acima do ponto de bifurcação. As cipselas são comumente truncadas ou rostradas no ápice, apresentam papilas arredondadas e pápus geralmente unisseriado e isomorfo (BREMER, 1994; KATINAS et al., 2009).

\section{Descrição}

Arbustos, subarbustos, ervas eretas ou rasteiras, trepadeiras herbáceas ou lenhosas, anuais ou perenes, monoicos, dioicos ou ginodioicos. Folhas alternas, raramente opostas ou rosuladas, esparsas ou densamente imbricadas, dispostas ou não em braquiblastos ou macroblastos (por exemplo, Brachyclados) ou apresentar gavinhas terminais (por exemplo, Mutisia), pecioladas, sésseis ou subsésseis; lâminas simples ou compostas, pinatissectas ou pinadas, liradas, deltoides, elípticas, espatuladas, lanceoladas, lineares, ovadas, obovadas, subuladas, coriáceas, cartáceas ou papiráceas, venação pinada, palmada a 3-nervada, raramente paralelinérvia, glabras, pubescentes, tomentosas ou lanosas. Capitulescência corimbiforme, racemiforme, paniculiforme, glomeruliforme ou capítulo solitário, invólucro campanulado, cilíndrico ou hemisférico; receptáculo epaleáceo, setoso, fimbriado, piloso ou glabro. Capítulos pedunculados ou sésseis, homógamos ou heterógamos, discoides, disciformes ou radiados, isomórficos ou heteromórficos com flores dimórficas, subdimórficas ou trimórficas (por exemplo, Chaptalia); brácteas involucrais unisseriadas ou multisseriadas, imbricadas. Flores casmógamas ou cleistógamas, amarelas, amarelo-alaranjadas, alaranjadas, brancas, lilás ou vermelhas, tubo da corola glabro, pubescente ou com tricomas 
glandulares. Capítulos, quando isomórficos, com todas as flores bissexuais ou rara e funcionalmente pistiladas, corolas liguladas, sub-bilabiadas a tubular-filiformes. Capítulos, quando heteromórficos, com flores marginais bissexuais, pistiladas ou neutras, corolas bilabiadas (Figura 1J), sub-bilabiadas ou do raio verdadeiras, com ou sem estaminódios; flores intermediárias (capítulos trimórficos) pistiladas, corolas filiformes a bilabiadas, com ou sem estaminódios; flores centrais bissexuais, funcionalmente pistiladas ou estaminadas, corolas bilabiadas, sub-bilabiadas, tubular-bilabiadas, tubularfiliformes a subcampanuladas; estames com apêndices apicais das anteras lanceolados, arredondados, agudos, apêndices basais das anteras caudados ou sagitados, raramente curtos, lisos a papilosos; estilete bilobado, ramos dorsalmente glabros a papilosos, papilas distribuídas acima do ponto de bifurcação, papilas curtas e arredondadas no ápice. Cipselas cilíndricas ou oblongas a obovadas, rostradas, atenuadas ou truncadas no ápice, glabras a pubescentes; pápus com cerdas escabrosas a plumosas, conadas ou não na base (por exemplo, Perdicium) ou ausente (por exemplo, Adenocaulon).

No Brasil, a tribo está representada pelos gêneros Chaptalia (17 spp.) (Figuras 2E-G), Lulia (1 sp.), Mutisia (4 spp.) (Figura 2H) e Trichocline (8 spp.) (Figuras 2I e 3A). Dentre as espécies de Chaptalia, oito são endêmicas do país, ocorrendo predominantemente no Sul do Brasil. Lulia, gênero monoespecífico, ocorre nos campos de altitude do domínio mata atlântica no Sudeste do Brasil, em banhados com turfeiras. Mutisia, com distribuição no Sudeste e Sul do país e em vegetação de Mata Atlântica, apresenta apenas uma espécie endêmica, Mutisia lutzii G.M. Barroso, encontrada na Serra do Caparaó, no estado de Minas Gerais. Trichocline apresenta duas espécies endêmicas do Sul do Brasil, T. catharinensis Cabrera e T. linearifolia Malme, a primeira ocorrendo amplamente em todo o Sul do país e a segunda restrita aos campos de altitude da Serra do Mar, nos estados do Paraná e São Paulo.

\section{Chave de identificação para os gêneros de Mutisieae no Brasil}

1. Ervas eretas; folhas alternas com nervação paralelinérvia ................ Lulia 1'. Ervas em roseta (Figuras 2G, I) ou trepadeiras; folhas com nervação pinada. 
2. Trepadeiras; folhas compostas, pinadas, com gavinhas terminais; cipselas cilíndricas, pápus formado por cerdas plumosas (Figura 1I)............... Mutisia 2'. Ervas em roseta; folhas simples, liradas ou lobadas a pinatissectas; cipselas oblongas a obovadas, pápus formado por cerdas escabrosas .......... 3

3. Sistema radicular extenso, formado por xilopódio; cipselas truncadas no ápice com tricomas claviformes, curtos e adensados (Figura 1K)

Trichocline

3'. Rizoma, quando presente, de dimensões pequenas; cipsela rostrada a atenuada no ápice, com tricomas alongados e esparsos ou ausentes 4

4. Capítulos com flores dimórficas ou trimórficas quando trimórficas, as intermediárias com corola bilabiada a filiforme-bilabiada, mais longa que o estilete ou do mesmo tamanho, estaminódios presentes, pápus plurisseriado Gerbera

4'. Capítulos com flores dimórficas ou trimórficas; quando trimórficas, as intermediárias com corola reduzida, filiforme, mais curta que o estilete, estaminódios ausentes, pápus unisseriado Chaptalia

\section{Literatura recomendada}

BREMER, K. Asteraceae: cladistics and classification. Portland: Timber Press, 1994.

BREMER, K.; JANSEN, R.K. A new subfamily of the Asteraceae. Annals of Missouri Botanical Gardens, Saint Louis, v. 79, p. 414-415, 1992.

Bremer, K., 1996. Major clades and grades of the Asteraceae. In: HIND, D. J. N.; BEENTJE, H. J. (Ed.). Compositae: Proceedings of the International Asteraceae Conference 1994. Kew: Royal Botanic Gardens, 1996. v. 1. p. 1-7.

BURKART, A. Estudio del género de Compuestas Chaptalia con especial referencia a las especies argentinas. Darwiniana, Buenos Aires, t. 6, n. 4, p. 505-594, 1944. 
CABRERA, A. L. Revisión del género Mutisia (Compositae). Opera Lilloana, Tucuman, v. 13, p. 5-227, 1965.

CABRERA, A. L.; KLEIN, R. M. Compostas. Tribo: Mutisieae. Flora Ilustrada Catarinense. Itajaí: Herbário Barbosa Rodrigues, 1973.

CABRERA, A. L. Mutisieae: systematic review. In: HEYWOOD, V. H.; HARBORNE, J. B.; TURNER, B. L. (Ed.). The Biology and Chemistry of the Compositae. London: Academic Press, 1977. v. 2. p. 1039-1066.

FUNK, V. A. et al. (Ed.). Systematics, Evolution and Biogeography of Compositae. Vienna: IAPT, 2009.

FUNK, V. A. et al. A phylogeny of the Gochnatieae: understanding a critically placed tribe in the Compositae. Taxon, Utrecht, v. 63, n. 4, p. 859-88, 2014.

HANSEN, H. V. Phylogenetic studies in the Gerbera complex (Compositae, tribe Mutisieae, subtribe Mutisinae). Nordic Journal of Botany, Copenhagen, v. 9, n. 5, p. 469-485, 1990.

HANSEN, H. V. Phylogenetic studies in Compositae tribe Mutisieae. Opera Botanica, Lund, v. 109, p. 1-50, 1991.

HIND, D. J. N. Tribe Mutisieae. In: KADEREIT, J. W.; JEFFREY, C. (Ed.). The Families and Genera of Vascular Plant: v. VIII: Flowering Plants Eudicots: Asterales. Berlin: Springer, 2007. p. 90-123.

JANSEN, R. K., PALMER, J. D., A chloroplast DNA inversion marks an ancient evolutionary split in the sunflower family (Asteraceae). Proceedings of the National Academy of Sciences of the United States of America, Washington, v. 84, n. 16 , p. 5818-5822, 1987.

KARIS, P. O., KALLERSJOÅN, M.; BREMER, K. Phylogenetic analysis of the Cichorioideae (Asteraceae) with emphasis on the Mutisieae. Annals of Missouri Botanical Garden, v. 79, p. 416-427, 1992.

KATINAS, L. The Gerbera-complex (Asteraceae, Mutisieae): to split or not to split. Sida, [S.1.], v. 21, p. 935-940, 2004.

KATINAS, L. et al. The subfamily Mutisioideae (Asteraceae). The Botanical Review, Bronx, n. 74, p. 469-716, 2008. 
KATINAS, L. et al. Mutisieae sensu stricto (Mutisioideae sensu strito). In: FUNK, V. A. et al. (Ed.). Systematics, Evolution, and Biogeography of Compositae. Vienna, Austria: International Association for Plant Taxonomy, 2009. p. 229-248.

MONDIN, C. A. A tribo Mutisieae Cass. (Asteraceae), sensu Cabrera, no Rio Grande do Sul e suas relações biogeográficas. 1996. 161 f. Dissertação (Mestrado em Botânica) - Instituto de Biociências, Universidade Federal do Rio Grande do Sul, Porto Alegre, 1996.

ORTIZ, S. et al. The basal grade of Compositae: Mutisieae (sensu Cabrera) and Carduoideae. In: FUNK, V. A. et al. (Ed.). Systematics, Evolution, and Biogeography of Compositae. Vienna, Austria: International Association for Plant Taxonomy, 2009. p. 193-213.

PANERO, J. L.; FUNK, V. A. New infrafamilial taxa in Asteraceae. Phytologia, Huntsville, v. 89, n. 3, p. 356-360, 2007.

PANERO, J. L.; FUNK, V. A. Toward a phylogenetic subfamilial classification for the Compositae (Asteraceae). Proceedings of the Biological Society of Washington, Washington, v. 115, n. 4, p. 909-922, 2002.

PANERO, J. L.; FUNK, V. A. The value of sampling anomalous taxa in phylogenetic studies: major clades of the Compositae revealed. Molecular Phylogenetics and Evolution, Orlando, v. 47, n. 2, p. 757-782, 2008.

ZARDINI, E. M. Lulia: un nuevo género de Compuestas. Boletín de la Sociedad Argentina de Botánica, Córdoba, v. 19, p. 255-258, 1980.

ZARDINI, E. M. Revision del género Trichocline (Compositae). Darwiniana, Buenos Aires, t. 19, n. 2/4, p. 618-733, 1975. 


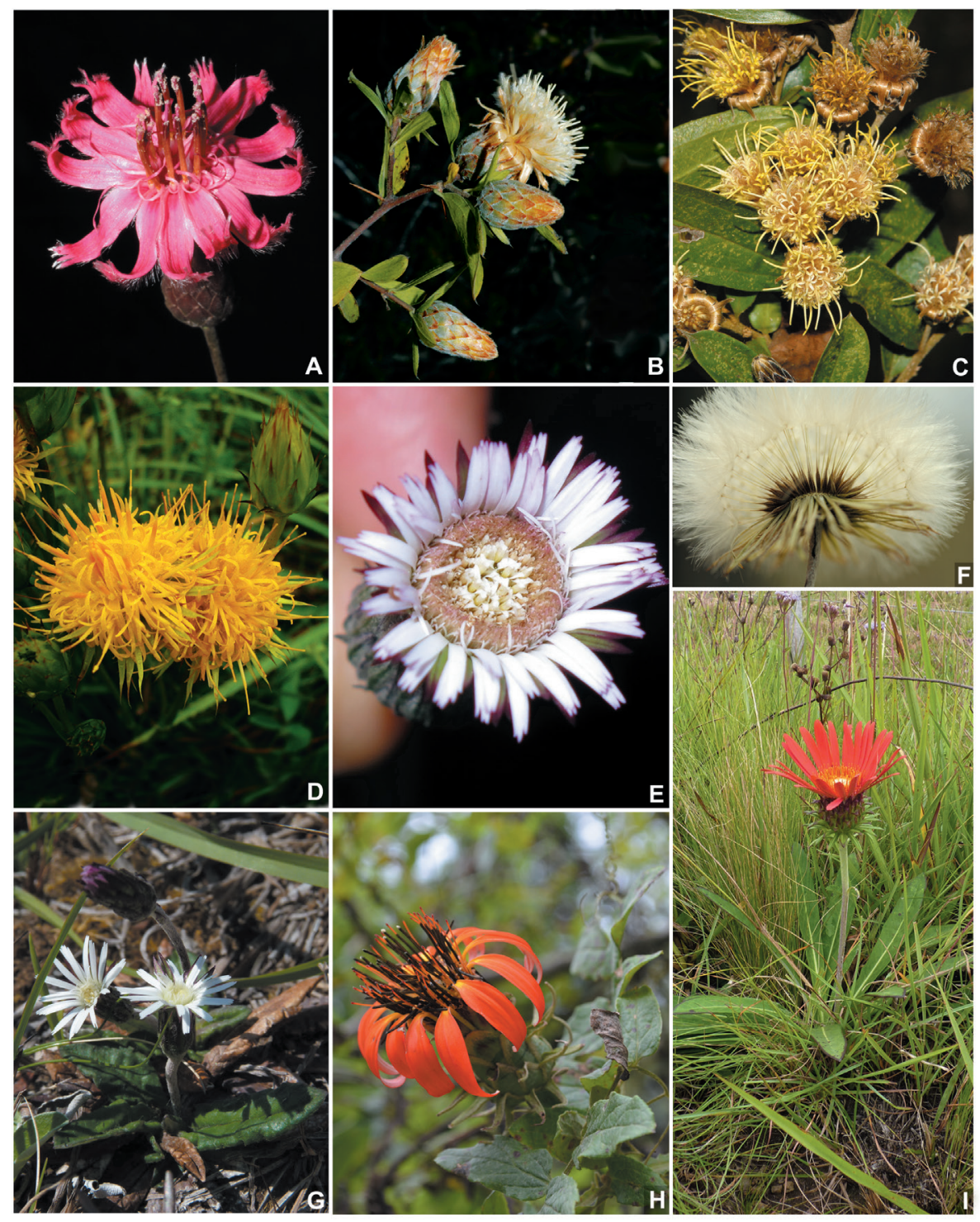

Figura 2. Barnadesieae. A. Barnadesia caryophylla (Vell.) S.F. Blake; B. Dasyphyllum sprengelianum (Gardner) Cabrera; C. Dasyphyllum spinescens (Less.) Cabrera; D. Schlechtendalia luzulifolia Less. Mutisieae. E.

Chaptalia nutans (L.) Polak; F. Chaptalia integerrima (Vell.) Burkart; G. Chaptalia runcinata Kunth. H. Mutisia campanulata Less.; I. Trichocline macrocephala Less. 

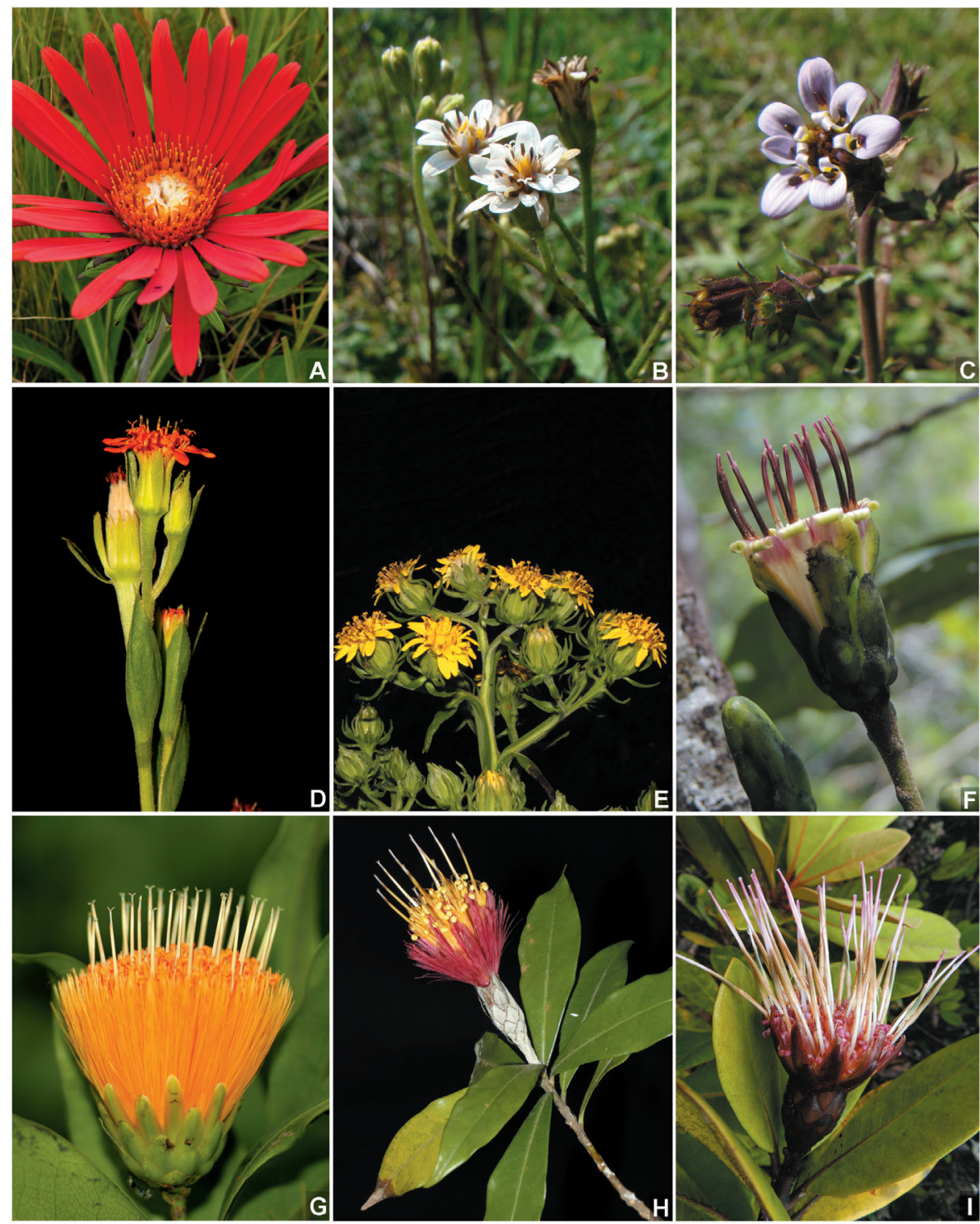

Figura 3. Mutisieae. A. Trichocline macrocephala Less.; Nassauvieae. B. Holocheilus pinnatifidus (Less.) Cabrera; C. Perezia squarrosa subsp. cubaetensis (Less.) Vuilleumemier; D. Trixis lessingii DC.; E. Trixis verbascifolia (Gardner) S.F. Blake; Stifftieae. F. Gongylolepis martiana (Baker) Steyerm. \& Cuatrec.; G. Stifftia chrysantha J.C. Mikan; H. Stifftia fruticosa (Vell.) D.J.N. Hind \& Semir. Wunderlichieae. I. Stenopadus talaumifolius S.F. Blake. 


\title{
TRIBO NASSAUVIEAE CASS.
}

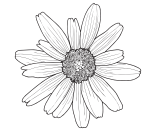 \\ Marcelo Monge \\ Fátima Otavina Souza-Buturi \\ João Semir \\ Liliana Katinas
}

Cassini (1819) propôs a primeira classificação para a família Asteraceae, na qual descreveu 20 tribos, dentre elas, Nassauvieae Cass. Segundo Cabrera (1977), a tribo já havia sido reconhecida anteriormente como um grupo taxonômico informal por Lagasca (1811), que agrupou todos os gêneros até então conhecidos de Asteraceae com corola bilabiada na "Ordo Chaenanthophorae", representada por 3 seções, das quais "Sectio I" era composta por 14 gêneros que, atualmente, pertencem a Nassauvieae. Posteriormente, Bentham (1873) reorganizou a família em 13 tribos, dentre elas, Mutisieae Cass., que foi subdividida em 5 subtribos, nas quais a tribo Nassauvieae foi englobada e transferida como subtribo, denominada Nassauviineae Less. O sistema de classificação de Bentham para a subtribo perdurou por mais de 100 anos (BAKER, 1876, 1884, CRISCI, 1974; CABRERA, 1977) e as primeiras modificações nessa classificação surgiram com os primeiros trabalhos de filogenia da família. Os recentes resultados de Funk e colaboradores $(2005,2009)$ e Panero e Funk $(2002,2008)$ evidenciaram o parafiletismo de Mutisieae, reconhecendo 3 clados relacionados à base da árvore filogenética: Onoserideae, Mutisieae e Nassauvieae. Embora esses resultados não alterem a circunscrição de Nassauviineae, a subtribo foi novamente elevada à categoria de tribo e é aceita como tal. Dessa forma, a tribo Nassauvieae, atualmente, é subordinada à subfamília Mutisioideae. 
Nassauvieae é composta por 25 gêneros e 315 espécies, apresentando distribuição neotropical (KATINAS et al., 2008), sendo um importante componente florístico nos Andes e Patagônia. (KATINAS et al., 2009; CABRERA, 1971) A maioria das espécies ocorre na América do Sul e algumas na América Central e América do Norte. A tribo é reconhecida pela presença dos capítulos discoides, flores com corola bilabiada e ramos do estilete truncados e penicelados. (BREMER, 1994; CABRERA, 1977; KATINAS et al., 2009)

\section{Descrição}

Ervas, subarbustos, arbustos e lianas. Folhas alternas ou rosuladas, simples, inteiras, pinatífidas ou pinatissectas, glabras ou com indumento, raramente com projeções espinescentes na margem e lâmina. Capitulescência racemiforme, corimbiforme, paniculiforme, raramente em glomérulo, ou capítulo solitário. Capítulos homógamos, discoides, raramente radiados ou disciformes, invólucro unisseriado ou multisseriado; receptáculo plano ou convexo, glabro ou com tricomas, paleáceo ou epaleáceo. Flores bissexuais, isomorfas, raramente dimorfas, corola bilabiada, lobo adaxial trilobado, lobos abaxiais solitários ou bilobados, revolutos (Figura 1M) ou eretos, raramente com corola tubulosa; anteras caudadas, apêndice apical obtuso ou agudo, cauda linear, glabro ou papiloso; estilete com ramos truncados, penicelados, raramente dorsalmente papilosos. Cipselas cilíndricas, obovoides, obcônicas, turbinadas, elipsoides, truncadas ou rostradas, com ou sem estrias, glabras ou com indumento; pápus unisseriado ou plurisseriado, cerdoso (Figura 1N), plumoso, paleáceo, ou raramente ausente.

No Brasil, Nassauvieae está representada por 7 gêneros e 37 espécies com distribuição extra-amazônica. (BFG, 2015) Cephalopappus Nees \& Mart. é um gênero monoespecífico e endêmico da floresta atlântica, ocorrendo no Nordeste e Sudeste; Criscia Katinas também é um gênero monoespecífico e ocorre no pampa, no estado do Rio Grande do Sul no Brasil, Argentina e Uruguai. (KATINAS, 1994) Holocheilus Cass. e Panphalea Lag. são gêneros sulamericanos restritos ao cone sul. Holocheilus está representado no Brasil por 6 espécies, dentre as quais 2 são endêmicas (Figura 3B). Panphalea possui 9 
espécies, e 3 delas são endêmicas do Brasil. Ambos os gêneros ocorrem em áreas úmidas da floresta atlântica e pampa; Jungia L.f. é um gênero americano e possui 2 espécies no Brasil, que ocorrem em áreas úmidas nas regiões centro-sul do país; Perezia Lag. (KATINAS, 2012) é um gênero sul-americano e, no Brasil, ocorrem 4 espécies e 2 subespécies, em áreas úmidas de campos de altitude da floresta atlântica (Figura 3C); Trixis P. Browne é um gênero neotropical que possui 15 espécies no Brasil, das quais 7 são endêmicas (KATINAS, 1996), sendo o gênero de Nassauvieae que apresenta a distribuição mais ampla no país (Figuras 3D-E).

\section{Chave de identificação para os gêneros de Nassauvieae no Brasil}

1. Pápus ausente 2

1'. Pápus presente 3

2. Lâmina foliar 4-11 cm larg., nunca pinatissecta; brácteas involucrais agudas; estigma arredondado, com tricomas nos ramos; cipsela suavemente rostrada no ápice

Cephalopappus

2'. Lâmina foliar 1-4 cm larg., as mais largas pinatissectas; brácteas involucrais apiculadas; estigma truncado, tricomas coletores no ápice; cipsela cilíndrica ou obovoide, truncada no ápice

Panphalea

3. Lâmina foliar palmada; receptáculo paleáceo; pápus plumoso Jungia 3’. Lâmina foliar não palmada; receptáculo epaleáceo; pápus cerdoso (Figura $1 \mathrm{~N})$

4. Receptáculo glabro Holocheilus

4’. Receptáculo piloso (Figura 1L). 5

5. Brácteas involucrais com ápice mucronado, margem hialina; corola lilás, rósea ou alva Perezia

5'. Brácteas involucrais com ápice agudo a arredondado, nunca mucronado, margem nunca hialina; corola amarela ou alaranjada 6 
6. Ervas escaposas; capítulos solitários ou aos pares Criscia

6'. Ervas caulescentes, subarbustos e arbustos; capitulescência com muitos capítulos Trixis

\section{Literatura Recomendada}

CABRERA, A. L. Asteraceae. In: CORREA, M. N. \& CABRERA, A. L. Flora Patagônica, Buenos Aires: INTA, 1971, v. 7. p. 1-151.

CASSINI, H. Suit du Sixième mémoire sur la famille des Synanthérées, contenant les caractères des tribus. Journal de Physique, de Chimie, d'Histoire Naturelle et des Arts, Paris, t. 88, p. 150-163, 1819.

BAKER, J. G. Compositae I. In: MARTIUS, C. P. von; EICHLER, A. W. (Ed.). Flora Brasiliensis. Lipsiae: [s.n.], 1876. v. 6, n. 2, p. 1-398.

BAKER, J. G. Compositae II - Mutisiaceae. In: MARTIUS, C. P. von; EICHLER, A. W. (Ed.). Flora Brasiliensis. Lipsiae: [s.n.], 1884, v. 6, n. 3, p. 339-398.

BRAZIL FLORA GROUP- BFG. Growing knowledge: an overview of seed plant diversity in Brazil. Rodriguésia, Rio de Janeiro, v. 66, n. 4, p. 10851113, 2015.

CABRERA, A. L. Mutisieae: systematic review. In: HEYWOOD, V. H.; HARBORNE, J. B.; TURNER, B. L. (Ed.). The Biology and Chemistry of the Compositae. London: Academic Press, 1977. v. 2. p. 1039-1066.

CRISCI, J. V. A numerical-taxonomic study of the subtribe Nassauviinae (Compositae, Mutisieae). Journal of the Arnold Arboretum, Cambridge, n. 55, p. 568-610, 1974.

BREMER, K. Asteraceae: cladistics and classification. Portland: Timber Press, 1994.

BENTHAM, G. Compositae. In: BENTHAM, G.; HOOKER, J. D. (Ed.). Genera Plantarum. London: Reeve, 1873, v. 2, n. 1, p. 163-533, 
FUNK, V. A. et al. Compositae metatrees: the next generation. In: FUNK, V. A. et al. (Ed.). Systematics, Evolution and Biogeography of Compositae. Vienna: IAPT, 2009. Chap. 44, p. 747-777.

FUNK, V. A. et al. Everywhere but Antarctica: using a supertree to understand the diversity and distribution of the Compositae. Biologiske Skrifter, Copenhagen, n. 55, p. 343-374, 2005.

KATINAS, L. et al. Mutisieae sensu stricto (Mutisioideae sensu strito). In: FUNK, V. A. et al. (Ed.). Systematics, Evolution, and Biogeography of Compositae. Vienna, Austria: International Association for Plant Taxonomy, 2009. p. 229-248.

KATINAS, L. Un nuevo género de Nassauviinae (Asteraceae, Mutisieae) y sus relaciones cladísticas con los géneros afines de la subtribu. Boletín de la Sociedad Argentina de Botánica, La Plata, n. 30, p. 59-70, 1994.

KATINAS, L. Revisión del género Perezia (Asteraceae). Boletín de la Sociedad Argentina de Botánica, La Plata, n. 47, p. 159-261, 2012.

KATINAS, L. Revisión de las especies sudamericanas del género Trixis (Asteraceae, Mutisieae). Darwiniana, Buenos Aires, n. 34, p. 27-108, 1996.

KATINAS, L. et al. The subfamily Mutisioideae (Asteraceae). The Botanical Review, Bronx, n. 74, p. 469-716, 2008.

LAGASCA, M. Dissertación sobre un orden nuevo de plantas de la classe de las compuestas. In: LAGASCA, M. Amenidades Naturales de les Españas. [S.1.: s.n.], 1811. n. 1, p. 26-44.

PANERO, J. L.; FUNK, V. A. Toward a phylogenetic subfamilial classification for the Compositae (Asteraceae). Proceedings of the Biological Society of Washington, Washington, v. 115, n. 4, p. 909-922, 2002.

PANERO, J. L.; FUNK, V. A. The value of sampling anomalous taxa in phylogenetic studies: major clades of the Compositae revealed. Molecular Phylogenetics and Evolution, Orlando, v. 47, n. 2, p. 757-782, 2008. 


\section{TRIBO ONOSERIDEAE (BENTHAM) PANERO \& V. A. FUNK}

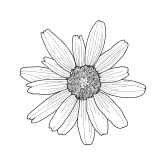

Eduardo Pasini

A tribo Onoserideae emergiu como um clado na subfamília Mutisioideae a partir de estudos filogenéticos moleculares realizados por Panero \& Funk (2007, 2008). Historicamente, a tribo estava inserida na tribo Mutisieae (CABRERA, 1977) e, posteriormente, teve seu posicionamento corroborado nessa mesma tribo por Katinas e colaboradores (2008), devido à presença e disposição das papilas no estilete, assim como a morfologia da corola.

Além das análises moleculares sustentarem o monofiletismo da tribo, estudos morfológicos realizados por Tellería \& Katinas (2004) reconheceram a corola tubular similar e o pápus dimórfico com cerdas estreitamente paleáceas como caracteres compartilhados entre os gêneros. A tribo é composta pelos gêneros Aphyllocladus Wedd., Gypothamnium Phil., Lycoseris Cass., Plazia Ruiz \& Pav., Onoseris Willd. e Urmenetea Phil. com 53 espécies distribuídas principalmente no norte dos Andes da Argentina, Chile, Bolívia e sul do Peru, sendo que somente Onoseris e Lycoseris ocorrem em florestas sazonalmente secas da América do Sul e Mesoamérica, como Guatemala e México (FUNK et al., 2009; PANERO; FUNK, 2008).

\section{Descrição}

Ervas anuais ou perenes, arbustos ou subarbustos, monoicos, eventualmente dioicos. Folhas alternas, rosuladas, ou agrupadas na parte distal dos ramos, sésseis ou pecioladas, lâmina simples, espatulada, linear, 
oblonga, orbicular ou ovada, margem inteira, serreada ou denteada, venação pinada, palmada ou uninérvea, face adaxial glabrescente, face abaxial pubescente. Capítulos pedunculados ou sésseis, solitários, em dicásios ou raramente formando capitulescência corimbiforme ou paniculiforme, homógamos ou heterógamos, radiados, disciformes ou discoides, isomórficos ou heteromórficos. Invólucro campanulado a hemisférico, 3-4-multisseriado, brácteas involucrais imbricadas, receptáculo epaleáceo, raramente alveolado ou fimbriado. Flores do raio pistiladas, com estaminódios, corola bilabiada a sub-bilabiada, lobo abaxial 3-dentado, lobo adaxial 1-2-dentado, raramente ausente, alaranjada, roxa, rosa ou alvo-arroxeada; flores do disco bissexuais ou funcionalmente estaminadas, corola tubulosa, 5-lobadas, lobos recurvados, algumas vezes com 1 lobo maior, vermelhas, amarelas, verde-amareladas, lilás, brancas ou rosa; anteras com apêndices apicais agudos, apiculados ou truncados; apêndices basais caudados ou calcarados, papilosos; estilete bífido, ramos com ápices arredondados ou truncados, dorsalmente glabros a raramente papilosos. Cipselas cilíndricas a turbinadas, glabras a pubescentes; pápus 2-4-seriado, a maioria heteromórfico, geralmente os mais externos com dimensões de comprimento maiores e achatados, cerdas capilares, escabrosas ou barbeladas.

No Brasil, a tribo Onoserideae está representada por 2 gêneros: Lycoseris - com apenas 1 espécie, Lycoseris boliviana Britton, encontrada em áreas de cerrado no estado do Mato Grosso do Sul - e Onoseris, com 2 espécies, $O$. brasiliensis Cabrera e 0 . fraterna S.F. Blake, distribuídas em áreas florestais do domínio cerrado nos estados do Mato Grosso e Acre, respectivamente.

\section{Chave de identificação para os gêneros de Onoserideae no Brasil}

1. Subarbusto dioico; folhas sésseis; capítulo solitário; cipsela glabra...

Lycoseris

1'. Subarbusto ou erva monoica; folhas pecioladas; capitulescência paniculiforme; cipsela pubescente.

Onoseris 


\section{Literatura recomendada}

CABRERA, A. L. Mutisieae: systematic review. In: HEYWOOD, V. H.; HARBORNE, J. B.; TURNER, B. L. (Ed.). The Biology and Chemistry of the Compositae. London: Academic Press, 1977. v. 2. p. 1039-1066.

FUNK, V. A. et al. (Ed.). Systematics, Evolution and Biogeography of Compositae. Vienna: IAPT, 2009.

HIND, D. J. N. Tribe Mutisieae. In: KADEREIT, J.W.; JEFFREY, C. (Ed.). The Families and Genera of Vascular Plant: v. VIII: Flowering Plants Eudicots: Asterales. Berlin: Springer-Verlag, 2007. p. 90-123.

KATINAS, L. et al. Mutisieae sensu stricto (Mutisioideae sensu strito). In: FUNK, V. A. et al. (Ed.). Systematics, Evolution, and Biogeography of Compositae. Vienna, Austria: International Association for Plant Taxonomy, 2009. p. 229-248.

KATINAS, L. et al. The subfamily Mutisioideae (Asteraceae). The Botanical Review, Bronx, n. 74, p. 469-716, 2008.

PANERO, J. L.; FUNK, V. A. New infrafamilial taxa in Asteraceae. Phytologia v. 89, n. 3, p. 356-360, 2007.

PANERO, J. L.; FUNK, V. A. The value of sampling anomalous taxa in phylogenetic studies: major clades of the Compositae revealed. Molecular Phylogenetics and Evolution, Orlando, v. 47, n. 2, p. 757-782, 2008.

TELLERÍA, M. C.; KATINAS, L. A comparative palynologic study of Chaetanthera (Asteraceae, Mutisieae) and allied genera. Systematic Botany, Kent, n. 29, p. 752-773, 2004. 


\title{
TRIBO STIFFTIEAE D. DON
}

\author{
हो \\ Lúcia Moura Conti \\ Nádia Roque
}

A tribo Stifftieae foi descrita por Don (1830) para incluir espécies de Stifftia J.C. Mikan, Anastraphia D. Don e Pentaphorus D. Don. Para o autor, a tribo poderia ser reconhecida pelas flores bissexuais, corola tubulosa, receptáculo epaleáceo, estames insertos na corola, anteras sagitadas e estigma papiloso. Posteriormente, diversos autores (CABRERA, 1977; MAGUIRE et al., 1957, PRUSKI, 1991) consideraram as espécies com corola actinomorfa de Stifftia e outros gêneros centrados nos tepuis (Guianas e Venezuela), como representantes da tribo Mutisieae. Em seguida, Pruski (2004) e Jeffrey (2004), acompanhados por Katinas e colaboradores (2008), recircunscreveram a tribo Stifftieae para incluir 6 gêneros (Chimantaea Maguire, Steyerm. \& Wurdack, Quelchia N.E. Br., Stenopadus S.F. Blake Stifftia, Stomatochaeta Maguire \& Wurdack e Wunderlichia Riedel ex Benth.) e 48 espécies, com base nos capítulos discoides e ramos do estilete rugosos a papilosos dorsalmente.

Estudos com base em marcadores moleculares (FUNK et al., 2009; PANERO; FUNK, 2008) propuseram uma nova circunscrição para a tribo Stifftieae, incluindo 11 gêneros, agrupados de maneira contrária a qualquer tratamento morfológico anterior (BREMER, 1994; KATINAS et al., 2008; KIM et al., 2002). A partir de estudos morfológicos em grados basais, Roque \& Funk (2013) reconheceram características exclusivas das anteras, cipsela e pápus entre Stifftioideae e Wunderlichioideae sem, contudo, distinguir sinapomorfias morfológicas para Stifftieae. Segundo, ainda, Panero e Funk (2008), a tribo Stifftieae está, atualmente, dividida em 3 clados: o ramo basal, composto apenas pelo gênero Stifftia e 2 clados irmãos, clado 
Gongylolepis (incluindo Glossarion Maguire \& Wurdack, Eurydochus Maguire \& Wurdack, Gongylolepis R.H. Schomb., Neblinaea Maguire \& Wurdack, Achnopogon Maguire, Steyerm. \& Wurdack, Duidaea S.F. Blake, Salcedoa Jiménez Rodr. \& Katinas e Quelchia N.E. Br.) e o clado Hyaloseris (incluindo Dinoseris Griseb. e Hyaloseris Griseb.).

Stifftieae, atualmente conta com 11 gêneros e cerca de 44 espécies, com distribuição sul americana (Argentina, Bolívia, Brasil, Colômbia, Guiana, Guiana Francesa e Venezuela).

\section{Descrição}

Arbustos, árvores ou lianas, raramente subarbustos, sem látex. Folhas simples, alternas, algumas vezes reunidas no ápice, ou alternas a opostas reunidas em braquiblastos, ou opostas; lâmina foliar com margem inteira a serrulada, revoluta ou parcialmente revoluta, tomentosa, lanosa, pubescente, glabrescente ou glabra, peciolada, algumas vezes pecíolo amplexicaule ou séssil a subséssil. Capitulescência monocéfala, corimbiforme, paniculiforme, racemiforme ou glomeruliforme, terminal, subterminal ou axilar; receptáculo epaleáceo, esparsamente hirsuto e foveolado em Neblinaea, glabro em Quelchia. Capítulos isomorfos, discoides, homógamos; invólucro cilíndrico, campanulado ou hemisférico, multisseriado, imbricado, desigual ou subigual. Flores 1-150, corola tubulosa, com 5 lobos enrolados no ápice ou profundamente divididos e enrolados em Stifftia, bilabiada ou ligulada, algumas vezes lobos enrolados no ápice, glabra ou pubérula, alva, creme, amarela, arroxeada, vermelha ou avermelhada; estames exsertos (Figuras $3 \mathrm{~F}$ e $4 \mathrm{~A}$ ), anteras alvas, creme, avermelhadas, roxas ou marrons, apêndice apical agudo ou acuminado, base geralmente caudada, caudas curtas ou longas, papilosas ou pubérulas, livres ou conadas com a base dos estames adjacentes; estilete alvo, creme, rosa, vermelho, roxo, bífido, bilobado ou clavado, ápice obtuso ou arredondado a agudo, glabro. Cipselas cilíndricas, prismáticas, obovadas, cilíndrico-turbinadas ou truncadas a atenuadas no ápice, geralmente 10-costadas, densamente pubescentes, vilosas, puberulentas, esparsamente pilosas no ápice, glabrescentes ou glabras (Figura 4B); pápus 3-4(5) séries, vistoso, vermelho, rosa, laranja, bronze, creme ou alvo; 
em geral, cerdoso, ou as internas subpaleáceas (Figura 4C), 100-150(-200) elementos, decíduas ou persistentes.

No Brasil, Stifftieae está representada por 5 gêneros: Gongylolepis, com 3 espécies distribuídas no Amazonas e Roraima (Figura 3F); Stifftia, com 5 espécies, todas endêmicas (Figuras 3G-H); Glossarion, Eurydochus e Neblinaea, com 1 espécie cada e todas restritas ao Amazonas. A maioria das espécies é encontrada exclusivamente em bordas de mata da floresta amazônica ou atlântica.

\section{Chave de identificação para os gêneros de Stifftieae no Brasil}

1. Corola actinomorfa, tubulosa (Figura 4A) Stifftia

1'. Corola zigomorfa, bilabiada ou ligulada 2

2. Lâmina foliar elíptica, tomentosa na face abaxial Glossarion

2'. Lâmina foliar obovada ou oblanceolada, glabra. 3

3. Invólucro cilíndrico, 0,5-0,8 cm larg.; capítulo com 2-5 flores... Neblinaea 3’. Invólucro campanulado, 1,8-5 cm larg.; capítulo com (9)13-50 flores .... 4

4. Folha peciolada (pecíolo 1-4 cm compr.); lâmina foliar com ápice acuminado; brácteas involucrais subiguais, pubescentes; cipsela pubescente, pápus mais curto que a corola. Eurydochus 4'. Folha geralmente séssil a subséssil; lâmina foliar com ápice arredondado, retuso ou obtuso; brácteas involucrais graduais, glabras (Figura 3F); cipsela glabra, pápus do mesmo tamanho ou maior que a corola Gongylolepis

\section{Literatura recomendada}

BREMER, K. Asteraceae: cladistics and classification. Portland: Timber Press, 1994.

CABRERA, A. L. Mutisieae: systematic review. In: HEYWOOD, V. H.; HARBORNE, J. B.; TURNER, B. L. (Ed.). The Biology and Chemistry of the Compositae. London: Academic Press, 1977. v. 2. p. 1039-1066. 
DON, D. Descriptions of new genera and species of the class Compositae belonging to the Floras of Peru, Mexico, and Chile. The Transactions of the Linnean Society of London, London, v. 16, n. 2, p. 169-303, 1830.

FUNK, V. A. et al. Classification of Compositae. FUNK, V. A. et al. (Ed.). Systematics, Evolution and Biogeography of Compositae. Vienna: IAPT, 2009. p. 171-188.

HIND, D. J. N. Tribe Mutisieae. In: KADEREIT, J.W.; JEFFREY, C. (Ed.). The Families and Genera of Vascular Plant: v. VIII: Flowering Plants Eudicots: Asterales. Berlin: Springer-Verlag, 2007. p. 90-123.

JEFFREY, C. Systema Compositarum (Asteracearum) nova. Botanicheskii Zhurnal, [S.1.], n. 89, p. 1817-1822, 2004.

KATINAS, L. et al. The subfamily Mutisioideae (Asteraceae). The Botanical Review, Bronx, n. 74, p. 469-716, 2008.

KIM, H. G. et al. Systematic implications of $\mathrm{ndhF}$ sequence variation in the Mutisieae (Asteraceae). Systematic Botany, [S.1.], n. 27, p. 598-609, 2002.

MAGUIRE, B. et al. The botany of the Guayana Highland. Memoirs of the New York Botanical Garden, New York, part. 2, n. 9, p. 235-392, 1957.

ORTIZ, S. The basal Grade of the Asteraceae: the fate of Mutisieae (sensu Cabrera) and the Carduoideae. FUNK, V. A. et al. (Ed.). Systematics, Evolution and Biogeography of Compositae. Vienna: IAPT, 2009. p. 193-213.

PANERO, J. L.; FUNK, V. A. The value of sampling anomalous taxa in phylogenetic studies: major clades of the Compositae revealed. Molecular Phylogenetics and Evolution, Orlando, v. 47, n. 2, p. 757-782, 2008.

PEREIRA, A. C. M. et al. Notas nomenclaturais em Stifftia J.C.Mikan (Stifftieae-Asteraceae). Acta Botânica Brasílica, Porto Alegre, v. 24, n. 3, p. 877-881, 2010.

PRUSKI, J. F. Asteraceae (Compositae). St. Louis: The Missouri Botanical Garden, 2004.

PRUSKI, J. F. Compositae of the Guayana Highland - V. The Mutisieae of the Lost World of Brazil, Colombia, and Guyana, Boletim do Museu Paraense de História Natural e Ethnographia, n. 7, p. 335-392, 1991. 
PRUSKI, J. F. Compositae of the Guayana Highland - II. Novelties in Gongylolepis and Stenopadus (Mutisieae). Annals of the Missouri Botanical Garden, Saint Louis, v. 76, n. 4, p. 993-1003, 1989a.

PRUSKI, J. F. Notes on the Compositae of the Guayana Highland - I. A new species of Stomatochaeta and the reduction of Guaicaia to Glossarion (Compositae: Mutiseae). Brittonia, Bronx, v. 41, n. 1, p. 35-40, 1989b.

ROBINSON, H. Two New Species of Stifftia with Notes on Relationships of the Genus (Asteraceae: Mutisieae). Systematic Botany, [S.1.], v. 16, n. 4, p. 685-692, 1991.

ROQUE, N.; FUNK, V. A. Morphological characters add support for some members of the basal grade of Asteraceae. Botanical Journal of the Linnean Society, London, v. 171, n. 3, p. 568-586, 2013. 


\title{
TRIBO WUNDERLICHIEAE PANERO \& V.A. FUNK
}

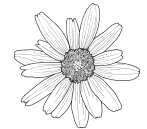 \\ Fátima Otavina de Souza-Buturi \\ Rosângela Simão-Bianchini \\ João Semir
}

Wunderlichieae foi recentemente estabelecida, após estudos moleculares (FUNK et al. 2009; PANERO; FUNK, 2007, 2008; ORTIZ et al., 2009) e morfológicos (ROQUE; FUNK; 2013). A tribo é constituída por quatro gêneros (Chimantaea Maguire, Steyerm. \& Wurdack, Stenopadus S.F. Blake, Stomatochaeta Maguire \& Wurdack e Wunderlichia Riedel ex Benth. \& Hook.f.), que anteriormente foram tratados como pertencentes às tribos Mutisieae (CABRERA, 1977, PRUSKI, 1989a, 1989b, 1991, HIND, 2007) ou Stifftieae (KATINAS et al., 2008).

Wunderlichieae está representada por 35 espécies, com distribuição restrita à América do Sul, com maior ocorrência no Planalto do Escudo Guiano. Chimantaea apresenta 9 espécies endêmicas da Venezuela (HIND, 2007; PRUSKI, 1997); Stenopadus com 15 espécies distribuídas nas regiões dos tepuis no Brasil, Colômbia, Guiana e Venezuela, além de 1 espécie ( $S$. andicola Pruski) nos Andes do Equador e Peru (HIND, 2007; PRUSKI, 1989a, PRUSKI; BELTRAN, 2003,); Stomatochaeta com 6 espécies ocorrendo no sudeste da Venezuela, Guiana e noroeste do Brasil (HIND, 2007; PRUSKI, 1997); e Wunderlichia, com 5 espécies endêmicas do Brasil e distribuição centrada no Planalto Brasileiro, especialmente nas regiões Sudeste e Centro-Oeste (BARROSO; MAGUIRE, 1973; SOUZA-BUTURI, 2013; SOUZA-BUTURI et al., 2015). 


\section{Descrição}

Subarbustos, arbustos ou árvores, monoicos, pouco ou muito ramificados, ramos aéreos persistentes ou caducos. Folhas simples, alternas, pseudoverticiladas ou espiraladas, frequentemente concentradas no ápice dos ramos, persistentes ou caducas, lâmina foliar normalmente coriácea, margem inteira, revoluta ou plana, às vezes repanda, indumento variado, glabrescente ou glabro, tricomas glandulares presentes em ambas as faces ou ausentes, pecioladas a sésseis. Capitulescência terminal, em racemo com poucos (Figura 5C) ou muitos capítulos, em cimeira de monocásios até dicásios modificados ou comumente capítulos solitários (Figuras 5AB). Capítulos discoides e homógamos; invólucro campanulado, cilíndrico, ovoide ou urceolado, brácteas involucrais em 3 a 10 séries, imbricadas (Figura 5D); receptáculo plano, levemente côncavo ou convexo, paleáceo ou epaleáceo, páleas caducas ou persistentes, alveolado. Flores 3-250, bissexuais, corola actinomorfa, tubulosa, tubo internamente glabro ou hirsuto, 5-lobada, lobos profundamente divididos, pubescentes ou glabros, revolutos, recurvados ou eretos, alva, creme, creme-esverdeada, amarelada, salmão ou magenta; estames exsertos, anteras com apêndice do conectivo agudo, acuminado, raro arredondado, base da antera caudada, inteira ou irregularmente bifurcada, papilosa ou glabra; estilete curtamente bilobado, ápice obtuso a arredondado, papiloso, papilas localizadas até abaixo do ponto de bifurcação, base cilíndrica ou bulbosa. Cipselas cilíndricas, oblongas, obcônicas ou subtetragonais, 4-10-costadas, geralmente inconspícuas, seríceas, vilosas ou glabras (Figura 4E); pápus multisseriado (3-7-seriado), subpaleáceo, cerdas livres ou conadas na base em um anel e caindo em uma unidade, margem inteira, escabra a barbelada, ápice glabro, alargado ou não, pubérulo, piloso a hirsuto.

Wunderlichieae está representada no Brasil por 3 gêneros: Stenopadus, com 2 espécies na região Norte, S. aracaënsis Pruski, endêmica da Serra do Araçá (Amazonas) e S. talaumifolius S.F. Blake, com ocorrência no Monte Roraima (Roraima) (Figura 3I); Stomatochaeta com 1 espécie, S. condensata (Baker) Maguire \& Wurdack (Figura 5A), encontrada também no Monte Roraima, e Wunderlichia, com 5 espécies endêmicas do Brasil (W. azulensis Maguire \& G.M. Barroso, W. crulsiana Taub., W. insignis Baill., W. mirabilis 
Riedel ex Baker e W. senae Glaz. ex Maguire \& G.M. Barroso) (Figuras 5B-D) e restrita de áreas abertas e pedregosas dos cerrados, campos rupestres, campos de altitude, inselbergs e caatinga nos estados da Bahia, Espírito Santo, Mato Grosso, Minas Gerais, Rio de Janeiro, São Paulo, Tocantins e Distrito Federal.

\section{Chave de identificação para os gêneros de Wunderlichieae no Brasil}

1. Folhas espiraladas, caducas; receptáculo densamente paleáceo; cipsela pilosa, raro glabra (conforme W. senae); pápus 4-7-seriado, cerdas unidas na base em anel. Restrito ao planalto brasileiro Wunderlichia 1'. Folhas alternas ou pseudoverticiladas, persistentes; receptáculo esparsamente paleáceo ou epaleáceo; cipsela glabra, pápus 3-seriado, cerdas livres. Restrito ao Planalto do Escudo Guiano.

2. Flores com corola magenta ou com lobos dourados, lobos flexíveis, enrolados, mais curtos ou do mesmo comprimento do tubo, tubo com 10-15 nervuras, inconspicuamente piloso próximo à fauce (Figuras 4D-E).

Stenopadus

2'. Flores com corola creme-amarelada, lobos rígidos, eretos ou levemente recurvados, mais longos do que o tubo, tubo com 5-10 nervuras, hirsuto próximo à fauce (Figura $4 \mathrm{~F}$ ).

Stomatochaeta

\section{Literatura Recomendada}

BARROSO, G. M.; MAGUIRE, B. A review of the Genus Wunderlichia

(Mutisieae, Compositae). Revista Brasileira de Biologia, São Carlos, v. 33, n. 3 , p. 379-406, 1973.

CABRERA, A. L. Mutisieae: systematic review. In: HEYWOOD, V. H.;

HARBORNE, J. B.; TURNER, B. L. (Ed.). The Biology and Chemistry of Compositae. London: Academic Press, 1977. v. 2. p. 1039-1066. 
FUNK, V. A. et al. Classification of Compositae. FUNK, V. A. et al. (Ed.).

Systematics, Evolution and Biogeography of Compositae. Vienna: IAPT, 2009. p.171-189.

FUNK, V. A. et al. (Ed.). Systematics, Evolution and Biogeography of Compositae. Vienna: IAPT, 2009b.

HIND, D. J. N. Tribe Mutisieae. In: KUBITZKI, K.; JEFFREY, C. (Ed.). The Families and Genera of Vascular Plant: v. VIII: Flowering Plants Eudicots: Asterales. Berlin: Springer-Verlag, 2007. p. 90-123.

KATINAS, L. et al. The subfamily Mutisioideae (Asteraceae). The Botanical Review, Bronx, n. 74, p. 469-716, 2008.

ORTIZ, S. The basal Grade of the Asteraceae: the fate of Mutisieae (sensu Cabrera) and the Carduoideae. FUNK, V. A. et al. (Ed.). Systematics, Evolution and Biogeography of Compositae. Vienna: IAPT, 2009. p. 193-213.

PANERO, J. L.; FUNK, V. A. New infrafamilial taxa in Asteraceae. Phytologia, [S.1.], v. 89, n. 3, p.356-360, 2007.

PANERO, J. L.; FUNK, V. A. New tribes in Asteraceae. Phytologia, [S.1.], v. 91, n. 3, 568-570, 2009.

PANERO, J. L.; FUNK, V. A. The value of sampling anomalous taxa in phylogenetic studies: major clades of the Compositae revealed. Molecular Phylogenetics and Evolution, Orlando, v. 47, n. 2, p. 757-782, 2008.

PRUSKI, J. F. Asteraceae. In: BERRY, E. P.; YATSKIEVYCH, K.; HOLST, B. K. (Ed.). Flora of the Venezuelan Guayana. St. Louis: Missouri Botanical Garden, 1997. p. 177-393.

PRUSKI, J. F. Compositae of the Guayana Highland - II. Novelties in Gongylolepis and Stenopadus (Mutisieae). Annals of the Missouri Botanical Garden, Saint Louis, v. 76, n. 4, p. 993-1003, 1989a.

PRUSKI, J. F. Compositae of the Guayana Highland - V. The Mutisieae of the Lost World of Brazil, Colombia, and Guyana, Boletim do Museu Paraense de História Natural e Ethnographia, n. 7, p. 335-392, 1991. 
PRUSKI, J. F. Notes on the Compositae of the Guayana Highland - I. A new species of Stomatochaeta and the reduction of Guaicaia to Glossarion (Compositae: Mutiseae). Brittonia, Bronx, v. 41, n. 1, p. 35-40, 1989b.

PRUSKI, J. F.; BELTRAN, H. Stenopadus andicola (Compositae: Mutisieae) a new generic record for Peru. Compositae Newsletter, [S.1.], n. 39, p. 2-8, 2003. ROQUE, N.; FUNK, V. A. Morphological characters add support for some members of the basal grade of Asteraceae. Botanical Journal of the Linnean Society, London, v. 171, n. 3, p. 568-586, 2013.

SOUZA-BUTURI, F. O. Taxonomia, palinologia e anatomia de Wunderlichia, Asteraceae. 2013. 156 f. Tese (Doutorado em Biologia) - Instituto de Biologia, Universidade Estadual de Campinas, Campinas, 2013.

SOUZA-BUTURI, F. O.; SIMÃO-BIANCHINI, R.; SEMIR, J. Lectotypification of species of Wunderlichia (Asteraceae). Kew Bulletin, London, v. 70, n. 2, p. 17, 2015. 


\section{TRIBO HYALIDEAE PANERO}

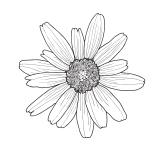

Nádia Roque

Hyalideae, juntamente com a tribo Wunderlichieae, compõem a subfamília Wunderlichioideae, estabelecida a partir de estudos filogenéticos moleculares (FUNK et al. 2009; PANERO; FUNK, 2007, 2008). A tribo inclui 2 clados, os gêneros sul americanos Hyalis D. Don (2 spp.) e Ianthopappus Roque \& D.J.N. Hind (1 sp.), que são nomeados como clado Hyalis, e os gêneros asiáticos, Leucomeris D. Don (2 spp.) e Nouelia Franch. (1 sp.), referidos como clado Leucomeris. Esses gêneros foram considerados parte ou próximos de Gochnatia (FREIRE; KATINAS; SANCHO, 2002; ROQUE; HIND, 2001), com base no apêndice da antera apiculado e ramos do estilete glabros.

Entretanto, o apêndice do conectivo agudo, cipsela 10-costada, 100150(200) elementos do pápus arranjados em 3-4(-5) séries provêm a hipótese de relação de parentesco entre Stifftioideae e Wunderlichioideae (tribos Hyalideae e Wunderlichieae), corroborando a segregação daqueles gêneros da tribo Gochnatieae (FUNK et al., 2014; ROQUE; FUNK 2013).

\section{Descrição}

Subarbustos, arbustos ou pequenas árvores. Folhas alternas, lâmina foliar linear a largamente obovada, inteira a levemente serreada, serícea a argêntea na face abaxial. Capitulescência em cimeiras paniculiformes, raramente corimbiformes, ou capítulos solitários, discoides ou radiados, homógamos ou heterógamos; receptáculo plano, epaleáceo; invólucro campanulado, brácteas involucrais 5-10 séries, imbricadas, graduadas, to- 
mentosas, seríceas ou glabrescentes. Flores marginais, quando presentes, bilabiadas, bissexuais ou pistiladas (Ianthopappus), flores do disco actinomorfas, 5 lobos revolutos, alvas ou púrpura; estames com apêndice do conectivo da antera apiculado, base caudada; estilete com ramos curtos a longos, arredondados, glabros. Cipselas cilíndricas a obovóides, 10-costadas, carpopódio anular, simétrico; pápus cerdoso, 3-4(-5) séries, (90)100-200 elementos cerdosos, cerdas de diferentes tamanhos, estramíneas ou púrpura (Ianthopappus).

A tribo Hyalideae está representada no Brasil por apenas um gênero monoespecífico, Ianthopappus corymbosus (Less.) Roque \& D.J.N. Hind, cuja distribuição ocorre no extremo sul do Brasil (Rio Grande do Sul), Argentina e Uruguai. (ROQUE; HIND, 2001) A espécie pode ser reconhecida pelo hábito subarbustivo, folhas sésseis, lâmina foliar orbicular, argêntea na face abaxial, venação actinódroma, capítulos radiados, heterógamos e pápus púrpura (Figura 5E).

\section{Literatura recomendada}

FREIRE, S. E.; KATINAS, L.; SANCHO, G. Gochnatia (Asteraceae, Mutisieae) and the Gochnatia complex: taxonomic implications from morphology. Annals of Missouri Botanical Garden 89: 524-550, 2002.

FUNK, V. A. et al. Mutisieae sensu stricto (Mutisioideae sensu stricto). In: FUNK, V. A. et al. (Ed.). Systematics, Evolution and Biogeography of Compositae. Vienna: IAPT, 2009. p. 171-189.

PANERO, J. L.; FUNK, V. A. New infrafamilial taxa in Asteraceae. Phytologia, [S.1.], v. 89, n. 3, p. 356-360, 2007.

PANERO, J. L.; FUNK, V. A. The value of sampling anomalous taxa in phylogenetic studies: major clades of the Compositae revealed. Molecular Phylogenetics and Evolution, Orlando, v. 47, n. 2, p. 757-782, 2008.

FUNK, V. A. et al. A phylogeny of the Gochnatieae: understanding a critically placed tribe in the Compositae. Taxon, Utrecht, v. 63, n. 4, p. 859888, 2014. 
ROQUE, N.; FUNK, V. A. Morphological characters add support for some members of the basal grade of Asteraceae. Botanical Journal of the Linnean Society, London, v. 171, n. 3, p. 568-586, 2013.

ROQUE, N.; HIND, D. J. N. Ianthopappus, a new genus of the Tribe Mutisieae (Compositae). Novon, Saint Louis, v. 11, n. 1, p. 97-101, 2001. 


\section{TRIBO GOCHNATIEAE (BENTH. \& HOOK. F.) PANERO \& V.A. FUNK}

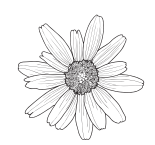

Nádia Roque

Gisela Sancho

Gochnatieae (subfamília Gochnatioideae) foi reconhecida como uma tribo dentre as linhagens basais de Asteraceae (PANERO; FUNK, 2002). Anteriormente, os gêneros estavam inseridos na subtribo Gochnatiinae, da tribo Mutisieae (CABRERA, 1977), mas a maioria das espécies foi excluída quando a circunscrição de Mutisieae revelou-se não monofilética (PANERO; FUNK, 2002, 2008). O tratamento taxonômico proposto por Panero e Funk (2002) reconheceu 4 gêneros em Gochnatieae: Cnicothamnus Griseb., Cyclolepis Gilles ex D. Don, Gochnatia Kunth, Richterago Kuntze e possivelmente Chucoa Cabrera.

Contudo, estudos moleculares recentes (FUNK et al., 2014) revelaram 8 clados monofiléticos em Gochnatieae, representados pelos gêneros Cnicothamnus (2 spp.), Richterago (16 spp.) (ROQUE; PIRANI, 2001, 2014), Pentaphorus D. Don (2 spp.) (Hind 2007), Anastraphia D. Don (33 spp.) (VENTOSA; HERRERA, 2011), Moquiniastrum (Cabrera) G. Sancho (21 spp.) (SANCHO; FUNK; ROQUE et al., 2013), Gochnatia Kunth (cerca de 8 spp.), Cyclolepis (1 sp.) e um gênero novo que inclui 7 espécies norte americanas. Dessa forma, a tribo totaliza cerca de 90 espécies, com distribuição restrita ao continente americano, desde o México (e áreas subjacente dos Estados Unidos), Caribe e América do Sul. 


\section{Descrição}

Ervas, subarbustos, arbustos ou árvores, monoicas, ginodioicas, ginomonoicas. Folhas simples, alternas, lâmina foliar discolor ou concolor, margem inteira, serreada, espinosa-denteada, denteada a denticulada, tomentosa, glabrescente ou glabra, tricomas glandulares sésseis, pecioladas a subsésses. Capitulescência racemiforme, espiciforme, corimbiforme, paniculiforme, glomeruliforme ou capítulo solitário e terminal, cilíndrico ou campanulado; receptáculo epaleáceo, plano a convexo. Capítulos discoides (Figuras 5F,G,I) ou radiados (Figura 5H), homógamos ou heterógamos, brácteas involucrais (2)3-15 séries, imbricadas, graduadas. Flores 3-300, tubo da corola glabro, pubescente ou com tricomas glandulares; flores do raio (quando presentes) com corola bilabiada $(3+1,3+2)$, pseudobilabiada $(4+1)$ ou sub-bilabiada (irregularmente lobada em Moquiniastrum), bissexuais (Cnicothamnus) ou pistiladas (Richterago, Moquiniastrum), alva, rósea ou laranja a laranja avermelhada, estaminódios 4-5 livres, hialinos (nas plantas ginodioicas, as flores da planta feminina não apresentam anteras); flores do disco bissexuais ou bissexuais e pistiladas ou todas pistiladas (Moquiniastrum, Cyclopepis), corola actinomorfa, com 5 lobos profundamente divididos, amarelo-alaranjada, amarela, creme-esverdeada, branca ou rósea, lobos eretos ou revolutos; estame com apêndice do conectivo da antera acuminado a apiculado, base da antera caudada, lisa a laciniada; estilete curtamente bilobado, glabro, ápice arredondado a obtuso (Figura 4G). Cipselas cilíndricas, costadas, vilosas, seríceas, tricomas glandulares bisseriados com vesículas em Anastraphia; pápus estramíneo, simples, cerdoso-escabroso, algumas vezes plumoso no ápice, raro paleáceo (Cnicothamnus), 1-3-seriado, 20 a 90 elementos, iguais ou desiguais no comprimento, livres a conados em um anel carnoso.

No Brasil, Gochnatieae está representada por três gêneros: Moquiniastrum, com 19 espécies, das quais 12 são endêmicas, e com distribuição extra-amazônica (Figuras 5F-G); Richterago, com 16 espécies endêmicas do Brasil e restrito a áreas abertas do domínio cerrado no leste do Brasil (Figuras 5H-I) e Gochnatia rotundifolia (Less.) Cabrera, uma espécie com registro para o cerrado no estado de São Paulo e que não tem sido coletada desde 1965. 


\section{Chave de identificação para os gêneros de Gochnatieae no Brasil}

1. Ervas em roseta ou subarbustos escaposos; flores alvas ou lilás, pápus unisseriado (Figura 4I) Richterago 1'. Árvores, arbustos, raramente subarbustos (M. cordatum); flores creme, pápus 2-3-seriado (Figura $4 \mathrm{H}$ ).

2. Plantas polígamo-dioicas ou ginodioicas; lâmina foliar com venação pinada; capítulos formando uma capitulescência (Figura 5G); invólucro 0,6$1 \times 0,4-0,7 \mathrm{~cm}$; flores 6-25, pápus cerdoso Moquiniastrum 2'. Plantas monoicas; lâmina foliar com venação trinervada; capítulos solitários no ápice dos ramos; invólucro $2,5 \times 2,5-3 \mathrm{~cm}$; flores mais 50 , pápus paleáceo na base e ápice plumoso

Gochnatia

\section{Literatura recomendada}

CABRERA, A. L. Mutisieae: systematic review. In: HEYWOOD, V. H.; HARBORNE, J. B.; TURNER, B. L. (Ed.). The Biology and Chemistry of the Compositae. London: Academic Press, 1977. v. 2. p. 1039-1066.

CABRERA, A. L. Revision del Genero Gochnatia. Revista Museo de La Plata, la Plata, v. 66, n. 12, p. 1-160, 1971.

FUNK, V. A. et al. A phylogeny of the Gochnatieae: understanding a critically placed tribe in the Compositae. Taxon, Utrecht, v. 63, n. 4, p. 859-888, 2014.

HIND, D. J. N. Tribe Mutisieae. In: K. KUBITZKI, K.; JEFFREY, C. (Ed.). The Families and Genera of Vascular Plant: v. VIII: Flowering Plants Eudicots: Asterales. Berlin: Springer-Verlag, 2007. p. 90-123.

PANERO, J. L.; FUNK, V. A. Toward a phylogenetic subfamilial classification for the Compositae (Asteraceae). Proceedings of the Biological Society of Washington, Washington, v. 115, n. 4, p. 909-922, 2002. 
PANERO, J. L.; FUNK, V. A. The value of sampling anomalous taxa in phylogenetic studies: major clades of the Compositae revealed. Molecular Phylogenetics and Evolution, Orlando, v. 47, n. 2, p. 757-782, 2008.

ROQUE, N.; PIRANI, J. R. Reinstatement of the name Richterago Kuntze and recircumscription of the genus to include species formerly treated as Actinoseris (Endl.) Cabrera (Compositae, Mutisieae). Taxon, Utrecht, v. 50, n. 4, p. 1155-1160, 2001.

ROQUE, N.; PIRANI, J. R. Taxonomic revision of Richterago Kuntze (Asteraceae, Gochnatieae). Systematic Botany, Kent, v. 39, n. 3, p. 997-1026, 2014.

SANCHO, G.; FREIRE, S. E. Gochnatieae (Gochnatioideae) and Hyalideae (Wunderlichioideae p.p.). In: FUNK, V. A. et al. (Ed.). Systematics, Evolution and Biogeography of Compositae. Vienna: IAPT, 2009. p. 249-265.

SANCHO, G.; FUNK, V. A.; ROQUE, N. Moquiniastrum (Gochnatieae, Asteraceae): a result of the paraphyletic Gochnatia. Phytotaxa, [S.1.], v. 147, n. 1, p. 26-34, 2013.

VENTOSA-RODRIGUEZ, I.; HERRERA OLIVER, P. P. Restoration of the name Anastraphia to define the species in the section Anastraphioides of Gochnatia (Gochnatioideae, Asteraceae). Compositae Newsletter, [S.1.], v. 49, p. 23-37, 2011. 


\title{
TRIBO TARCHONANTHEAE KOSTEL.
}

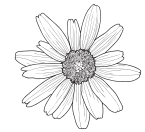 \\ Gustavo Heiden \\ João de Deus Medeiros
}

Tarchonantheae foi proposta por Kosteletzky (1833), compreendendo os gêneros Tarchonanthus L. e Brachylaena R. Br. A aceitação da tribo não foi imediata e o posicionamento desses gêneros em outras tribos, como Multisieae (BREMER, 1994) e Cardueae (HANSEN, 1991), variou ao longo da história. O monofiletismo de Tarchonantheae foi corroborado por estudos moleculares (KEELEY; JANSEN, 1991, KIM; LOOCKERMAN; JANSEN, 2002, FUNK et al., 2005), que reconheceram o seu posicionamento em Carduoideae.

Tarchonantheae compreende apenas os gêneros Tarchonanthus, com 2 (BEENTJE, 1999) ou 6 espécies (HERMAN, 2002), e Brachylaena com 11 espécies (BEENTJE, 2000). A tribo pode ser caracterizada pelas plantas dioicas, capítulos discoides ou disciformes, flores actinomorfas, unissexuais, anteras caudadas, calcaradas (Figura 4J), ramos do estilete curtos, agudos a obtusos, glabros, pápus cerdoso em 1-2 séries ou ausente. Todos os representantes da tribo são nativos da África e Península Arábica (ORTIZ, 2009), com uma espécie introduzida no Brasil (BFG, 2015).

\section{Descrição}

Arbustos ou árvores, dioicos, sem látex; folhas alternas. Capitulescência paniculiforme; receptáculo epaleáceo, alveolado, glabro ou piloso. Capítulos discoides ou disciformes, unissexuais, raramente com algumas 
flores bissexuais; invólucro campanulado a obcônico, brácteas involucrais imbricadas, margens hialinas. Flores com corola amarelada ou esbranquiçada; flores masculinas com corola actinomorfa, profundamente 5-lobada; estames com apêndice apical da antera deltado, anteras calcaradas e caudadas, pistilódio reduzido; flores femininas com corola actinomorfa 3-5-lobada, tubular a filiforme, estames reduzidos ou ausentes, estilete com ramos curtos e recurvados, agudos a obtusos no ápice, glabros. Cipselas cilíndricas a elipsoides, costadas, setulífera, carpopódio anuliforme; pápus ausente ou 1-2-seriado, barbelado.

Brachylaena discolor DC. (Figura 6A) é a única espécie da tribo ocorrente no Brasil. Nativa da África do Sul, Botsuana, Moçambique, Suazilândia e Zimbábue (BEENTJE, 2000), foi introduzida no país em meados de 1960 para a estabilização de dunas na praia do Moçambique, Parque Estadual do Rio Vermelho, na ilha de Santa Catarina, em Florianópolis, onde naturalizou-se, expandindo sua distribuição até a praia do Campeche, cerca de 30 quilômetros em direção ao sul da ilha, onde permanece restrita.

\section{Literatura recomendada}

BEENTJE, H. J. The genus Tarchonanthus (Compositae-Mutisieae), Kew Bulletin, London, v. 54, n. 1, p. 81-95, 1999.

BEENTJE, H. J. The genus Brachylaena (Compositae-Mutisieae). Kew Bulletin, London, v. 55, n. 1, p. 1-41, 2000.

BRAZIL FLORA GROUP - BFG. Growing knowledge: an overview of seed plant diversity in Brazil. Rodriguésia, Rio de Janeiro, v. 66, n. 4, p. 10851113, 2015.

BREMER, K. Asteraceae: cladistics and classification. Portland: Timber Press, 1994.

FUNK, V.A. et al.. Everywhere but Antarctica: using a supertree to understand the diversity and distribution of the Compositae. Biologiske Skrifter, Copenhagen, v. 55 p. 343-373, 2005. 
HANSEN, H. V. SEM-studies and general comments on pollen in tribe Mutisieae (Compositae) sensu Cabrera. Nordic Journal of Botany, Copenhagen, v.10, p. 607-623, 1991.

HERMAN, P. P. J. Revision of the Tarchonanthus camphoratus complex (Compositae, Tarchonantheae) in southern Africa. Bothalia, Pretoria, v. 32, n. 1, p. 21-28, 2002.

KEELEY, S. C.; JANSEN, R. K. Evidence from chloroplast DNA for the recognition of a new tribe, the Tarchonantheae, and the tribal placement of Pluchea (Asteraceae). Systematic Botany, Kent, v. 16, n. 1, p. 173-181, 1991. KIM, H.-G.; LOOCKERMAN, D. J.; JANSEN, R. K. Systematic implications of $n d h F$ sequence variation in the Mutisieae (Asteraceae). Systematic Botany, Kent, v. 27, n. 3, p. 598-609, 2002.

KOSTELETZKY, V. F. Allgemeine medizinisch-pharmazeutische Flora. Prague: Borrosch \& Andre, 1833. v. 2

ORTIZ, S. Tarchonantheae (Carduoideae). In: FUNK, V. A. et al. (Ed.). Systematics, Evolution and Biogeography of Compositae. Vienna: IAPT, 2009. p. 279-285. 


\section{TRIBO CARDUEAE CASS.}

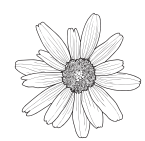

Angelo Alberto Schneider

A tribo Cardueae é uma das maiores da família, com cerca de 2.400 espécies, distribuídas em 72 gêneros (SUSANNA; GARCIA-JACAS, 2007, 2009), e está representada principalmente por espécies conhecidas popularmente como "cardos", devido à presença de espinhos e projeções espinescentes por toda a planta. Apresenta distribuição euroasiática (principalmente mediterrânea), com poucos representantes na África e América.

\section{Descrição}

Ervas anuais, bianuais ou perenes, geralmente com projeções espinescentes por toda a planta; células laticíferas geralmente presentes nas partes aéreas. Raízes com ductos de resina. Folhas alternas, frequentemente dispostas em roseta, inteiras, mais comuns lobadas e decorrentes, espinescentes ou não. Capitulescência corimbiforme, raro glomeriforme, ou solitários em escapo. Capítulos discoides ou disciformes, raro radiados, homógamos ou heterógamos, com muitas flores; brácteas involucrais imbricadas em várias séries, espinescentes ou não, foliáceas ou membranáceas, com ápice fimbriado, lacerado, inerme ou espinescente; receptáculo escamoso ou setoso, raramente glabro. Flores normalmente com corola tubulosa, férteis ou estéreis na periferia, corola geralmente actinomorfa, raro zigomorfa; estames com anteras sagitadas, caudadas na base, apêndice do conectivo rígido, lignificado e lanceolado, filetes glabros ou papilosos; estilete com um espessamento papiloso-piloso logo abaixo da divisão dos 
ramos do estilete, estilopódio presente. Cipselas variáveis, estreitas ou espessas, lustrosas, raro rostradas, glabras ou hirsutas, inserção do carpopódio basal, basal-lateral ou lateral; pápus escamoso ou cerdoso, geralmente duplo, raramente ausente.

A tribo Cardueae está representada no Brasil por 7 gêneros: Arctium L. (Figura 6B), Carduus L. (Figura 6C), Carthamus L. (Figura 6D), Centaurea L. (Figuras 6E-F), Cirsium Mill. (Figura 6G), Cynara L. e Silybum Vaill., sendo que, destes, apenas Centaurea apresenta uma única espécie autóctone, $C$. tweediei Hook. \& Arn. (Figura 6F), que ocorre no estado do Rio Grande do Sul.

\section{Chave de identificação para os gêneros de Cardueae no Brasil}

1. Cipselas com carpopódio inserido basalmente 2

1'. Cipselas com carpopódio inserido lateralmente 6

2. Plantas inermes; brácteas involucrais subuladas, ápice em forma de gancho (Figura 6B). Arctium

2'. Plantas com espinhos; brácteas involucrais espinescentes, ápice reto (sem forma de gancho) (Figuras 6E-F). 3

3. Lâmina foliar branco-variegada; brácteas involucrais com espinhos laterais; pápus de cerdas decíduas. Silybum 3'. Lâmina foliar coloração uniforme (não branco-variegada); brácteas involucrais sem espinhos laterais; pápus destacado em anel.

4. Cerdas do pápus simples Carduus

4'. Cerdas do pápus plumosas 5

5. Plantas cultivadas; receptáculo carnoso; cipsela com carúncula globosa no ápice. Cynara 5'. Plantas subespontâneas; receptáculo não carnoso; cipsela sem carúncula no ápice Cirsum 
6. Capítulos com brácteas involucrais foliáceas (Figura 6D); cipselas dimórficas (mais externas sem pápus, rugosas, e mais internas com pápus, lisas

Carthamus

6'. Capítulos com brácteas involucrais escariosas, raramente foliáceas (Figuras 6E-F); cipselas isomórficas Centaurea

\section{Literatura recomendada}

CABRERA, A. L. Compositae. In: BURKART, A. (Org.). Flora Ilustrada de Entre Rios (Argentina). Buenos Aires: Colecion Cientifica del INTA. 1974. p. 106-554.

SUSANNA, A.; GARCIAS-JACAS, N. Tribe Cardueae. In: KADEREIT, J. W.; JEFFREY, C. (Ed.). The Families and Genera of Vascular Plants: v. 8: Flowering Plants: Eudicots - Asterales. Berlin: Springer-Verlag, 2007. p. 123-147.

SUSANNA, A.; GARCIAS-JACAS, N. Cardueae. In: FUNK, V. A.et al. (Ed.) Systematics, Evolution and Biogeography of Compositae. Viena: IAPT, 2009. p. 249-265. 


\section{TRIBO CICHORIEAE LAM. \& DC.}

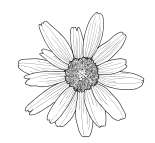

Angelo Alberto Schneider

Cichorieae é uma tribo de ocorrência predominante no Hemisfério Norte e possui cerca de 93 gêneros e 1.400 espécies, sem considerar as espécies dos gêneros Hieracium L., Pilosella Hill e Taraxacum F.H. Wigg., que apresentam inúmeras espécies apomíticas e complexos de espécies (KILIAN; GEMEINHOLZER; LACK, 2009). A tribo inclui muitas plantas ruderais presentes na flora brasileira, como algumas espécies dos gêneros Crepis L., Hypochaeris L., Sonchus L. e Youngia Cass. Dessa tribo, também são as plantas cultivadas dos gêneros Cichorium L. (almeirão) e Lactuca L. (alface).

\section{Descrição}

Ervas anuais ou perenes, raramente subarbustos, arbustos ou ervas volúveis; presença de látex abundante. Folhas geralmente alternas, muitas vezes dispostas em roseta, inteiras, lobadas a pinatissectas, raramente espinescentes (Scolymus L.). Capitulescência ou capítulos solitários. Capítulos ligulados, homógamos; brácteas involucrais em uma única série ou imbricadas em várias séries; receptáculo geralmente epaleáceo, glabro, raramente escamoso-cerdoso ou paleáceo (Hypochaeris). Flores bissexuais, corola ligulada, lígula 5-lobada, amarela, branca, azul ou lilás; estames com anteras com apêndice do conectivo alongado e obtuso, calcaradas e caudadas; estilete delgado, geralmente com ramos longos e finos, pilosidade no eixo do estilete e ramos. Cipselas e pápus de várias formas, sendo que muitas espécies possuem cipselas rostradas. 
A tribo Cichorieae está representada no Brasil por 11 gêneros, sendo 8 exóticos (Cichorium, Crepis, Lactuca, Lapsana L., Picris L., Sonchus, Taraxacum e Youngia) e apenas Hieracium, Hypochaeris e Picrosia com representantes nativos. No Brasil, são encontrados Cichorium L., com espécies cultivadas ou ainda ocorrendo como subespontâneas, $C$. intybus L. (almeirão) e C. endivia L. (chicória), nativas do Velho Mundo (CABRERA, 1974); Crepis, gênero exótico e com poucas espécies subespontâneas no Sul do Brasil (C. capillaris (L.) Wallr. e C. setosa Haller f.); Hieracium L., com 4 espécies nativas; Hypochaeris L., com 11 espécies nativas e algumas exóticas; Lactuca L., gênero exótico, no Brasil, ocorrem L. serriola L. como adventícia e L. sativa L., cultivada (alface); Lapsana L., gênero exótico, no Brasil, ocorre apenas L. communis L. de forma adventícia; Picris L., com apenas P. echioides L., adventícia na fronteira do Rio Grande do Sul com o Uruguai; Picrosia D. Don, com apenas 2 espécies nativas, P. longifolia D. Don e P. cabreriana A.G. Schulz, com distribuição nas regiões Sul, Sudeste e Centro-Oeste (Mato Grosso do Sul), em campos úmidos; Sonchus L., com 2 espécies exóticas (Figura 6H); Taraxacum Weber, com apenas T. officinale Weber ex F.H. Wigg. (Figura 6I), espécie presente em todo o mundo (CABRERA, 1974); e Youngia Cass., gênero asiático, sendo que, no Brasil, é encontrada Y. japonica (L.) DC., planta ruderal.

\section{Chave de identificação para os gêneros de Cichorieae no Brasil}

1. Flores com corola azul; pápus diminuto, formado por escamas

Cichorium

1'. Flores com corola amarela, branca ou lilás; pápus vistoso, cerdoso plumoso ou ausente

2. Pápus ausente Lapsana

2’. Pápus presente 3

3. Cerdas do pápus plumosas............................................................................. 4

3'. Cerdas do pápus escabrosas ..................................................................... 5 
4. Receptáculo paleáceo Hypochaeris

4'. Receptáculo epaleáceo Picris

5. Frutos tuberculados na parte superior (Figura 4L) Taraxacum

5'. Frutos lisos na parte superior. ... 6

6. Cipselas comprimidas 7

6'. Cipselas cilíndricas (não comprimidas) 8

7. Cipselas rostradas (Figura $4 \mathrm{~K}$ ). Lactuca

7’. Cipselas sem rostro. Sonchus

8. Flores com corola branca ou rosada. Picrosia

8 '. Flores com corola amarela..... 9

9. Plantas densamente cobertas de tricomas ramificados Hieracium 9'. Plantas glabras ou com poucos tricomas não ramificados 10

10. Cipselas cilíndricas, 10-20-costadas. Crepis 10'. Cipselas fusiformes, 4-5-costadas. Youngia

\section{Literatura Recomendada}

AZEVEDO-GONÇALVES, C. F.; MATZENBACHER, N. I. O gênero Hypochaeris L. (Asteraceae) no Rio Grande do Sul, Brasil. Theringia: Série Botânica, Porto Alegre, v. 62, n. 1/2, p. 55-87, 2007.

CABRERA, A. L. Compositae. In: BURKART, A. (Ed.). Flora ilustrada de entre rios (Argentina). Buenos Aires: INTA, 1974. p. 106-554. v. 6.

KILIAN, N.; GEMEINHOLZER, B.; LACK, W. Cichorieae. In: FUNK, V. A. et al. (Ed.). Systematics, Evolution, and Biogeography of Compositae. Vienna: IAPT, 2009. p. 343-385.

LACK, H.W. Tribe Cichorieae. In: KADEREIT, J.W.; JEFFREY, C. (Ed.). The Families and Genera of Vascular Plant: v. VIII: Flowering Plants Eudicots: Asterales. Berlin: Springer-Verlag, 2007. p. 180-199. 


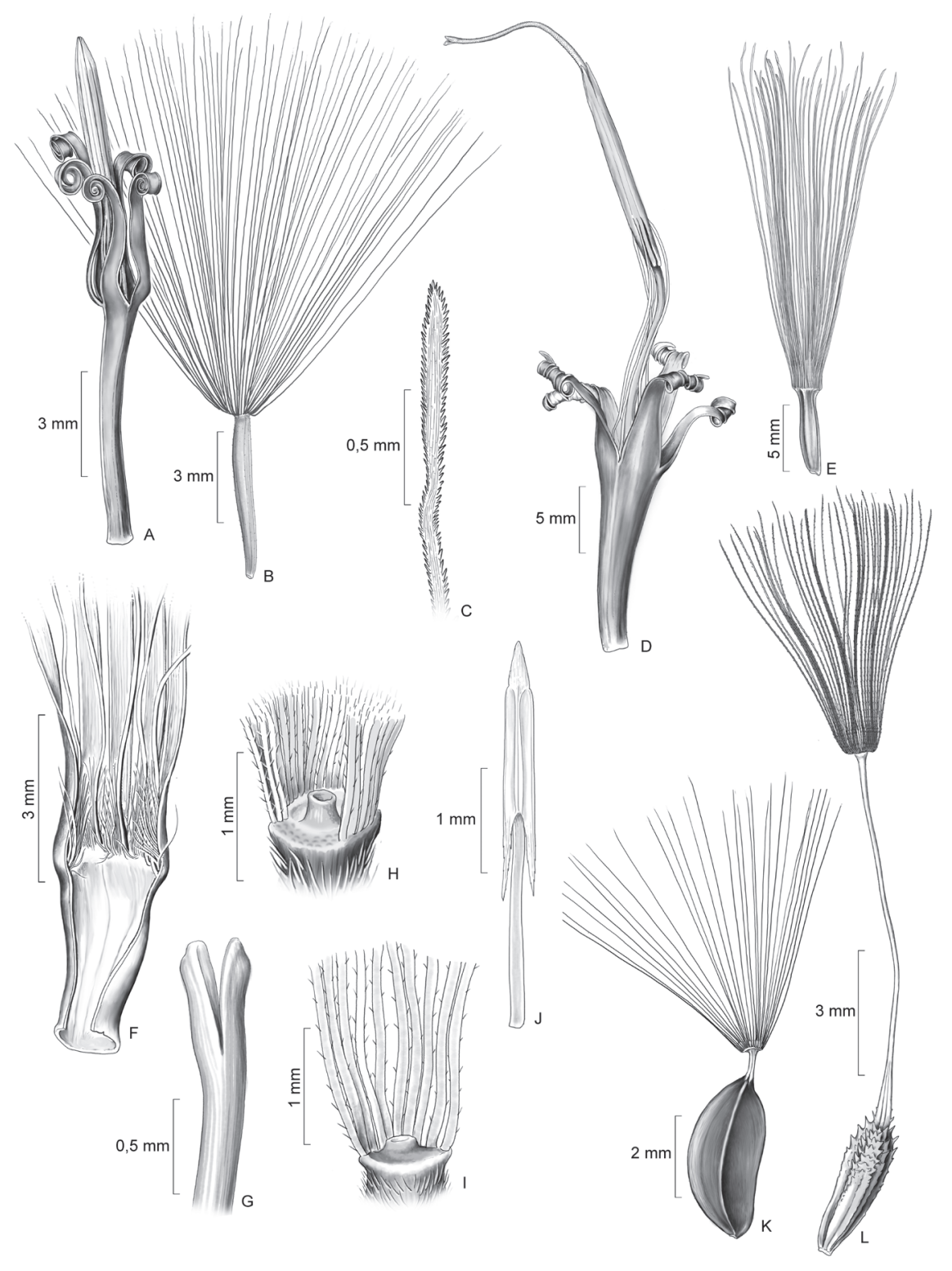

Figura 4. Stifftieae. A-C. Stifftia hatschbachii H. Rob.: A. Corola com lobos revolutos e estames; B. Cipsela e pápus; C. Detalhe da cerda do pápus. Wunderlichieae. D-E. Stenopadus talaumifolius S.F. Blake; D. Corola, estames e estilete; E. Cipsela e pápus; F. Corola evidenciando os tricomas no tubo de Stomatochaeta condensata (Baker) Maguire \& Wurdack. Gochnatieae. G-H. Moquiniastrum paniculatum (Less.) G. Sancho; G. Ramos do estilete com ápice glabro e obtuso; H. Cipsela e pápus 2-3-seriado; I. Cipsela e pápus unisseriado de Richterago discoidea (Less.) Kuntze. Tarchonantheae. J. Antera (caudada e calcarada) de Brachylaena discolor DC. Cichorieae. K. Cipsela e pápus de Lactuca sp.; L. Cipsela e pápus de Taraxacum officinale Weber ex Wigg. 

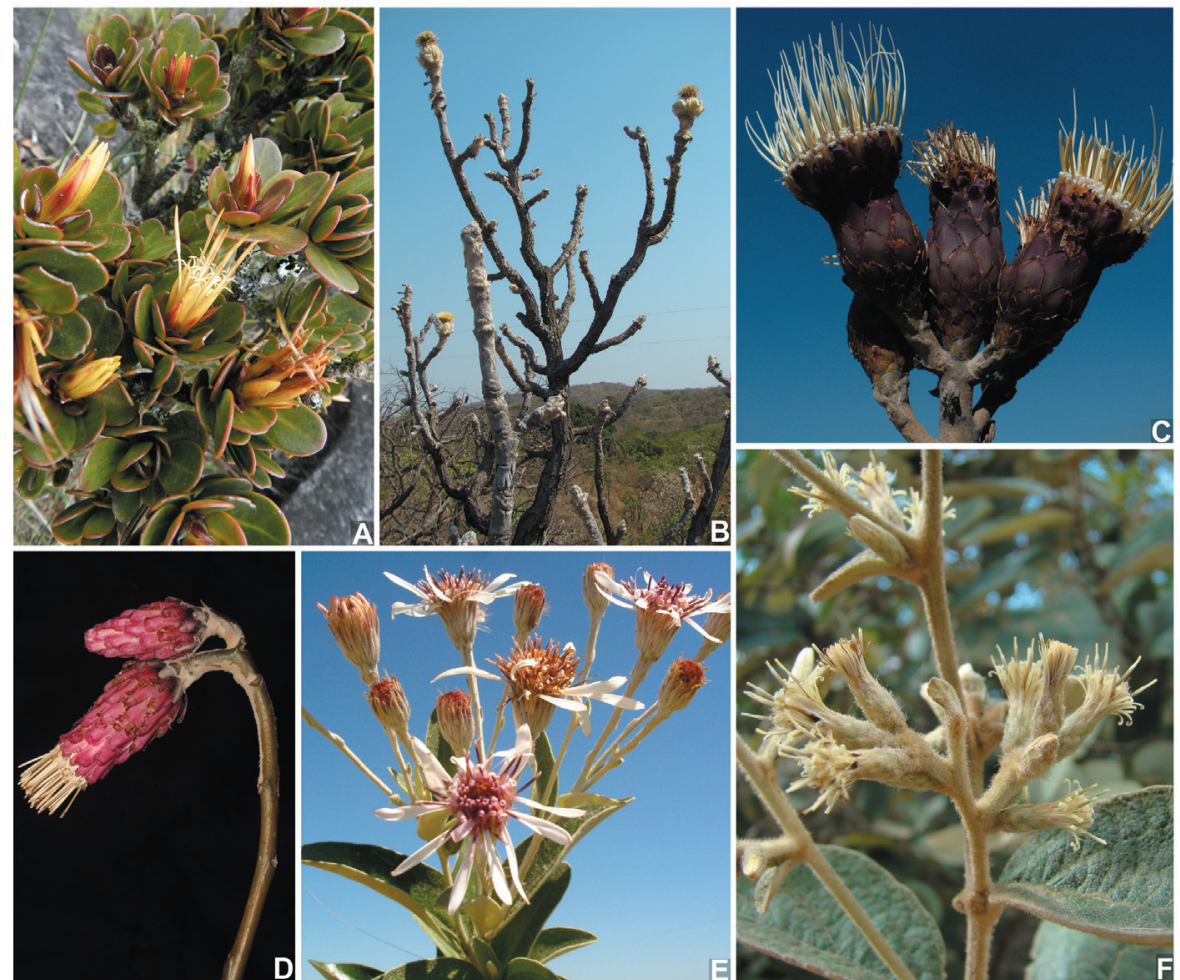

C
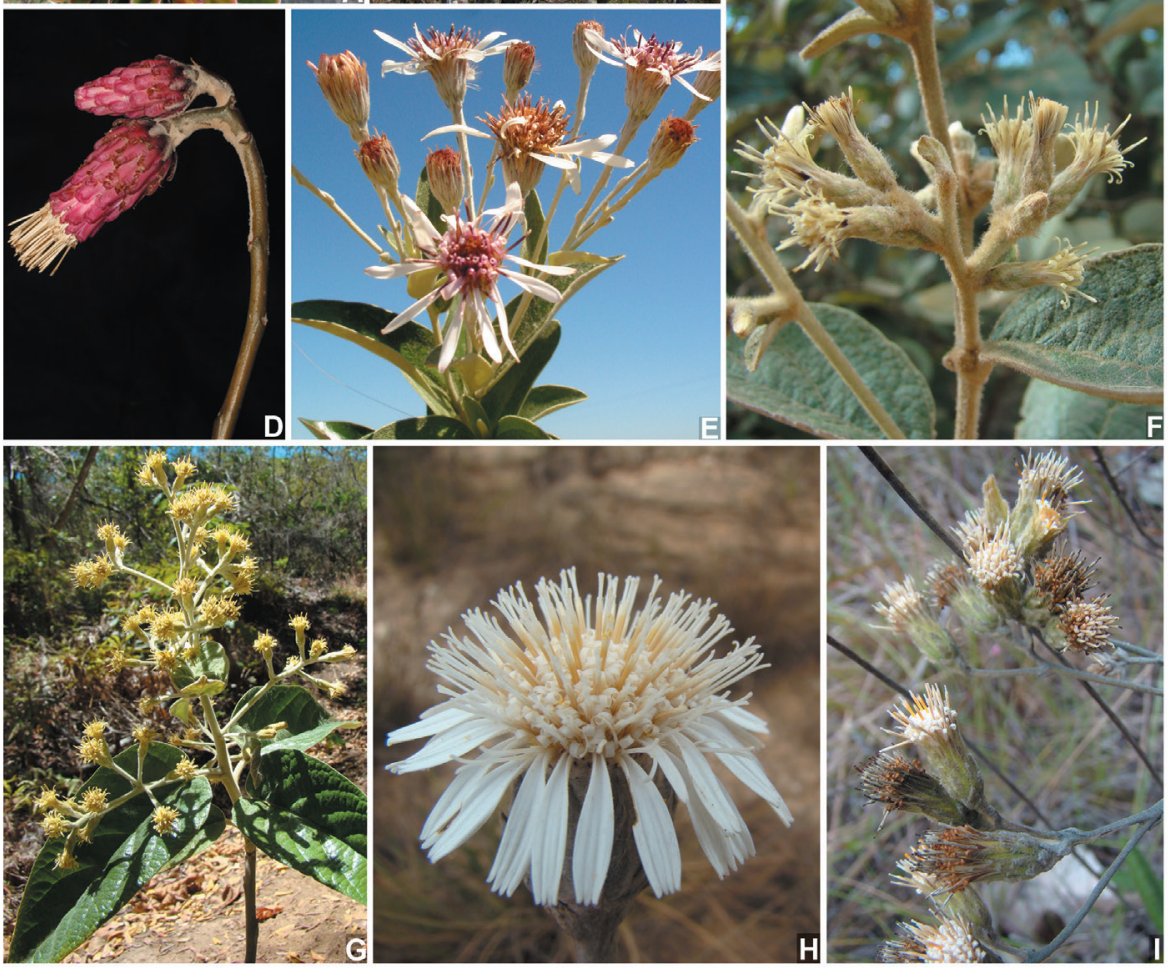

Figura 5. Wunderlichieae. A. Stomatochaeta condensata (Baker) Maguire \& Wurdack; B. Wunderlichia mirabilis Riedel ex Baker; C. Wunderlichia cruelsiana Taub.; D. Wunderlichia insignis Baill. Hyalideae. E. lanthopappus corymbosus (Less.) Roque \& D.J.N. Hind. Gochnatieae. F. Moquiniastrum paniculatum (Less.) G. Sancho; G. Moquiniastrum polymorphum (Less.) G. Sancho; H. Richterago arenaria (Baker) Roque; I. Richterago discoidea (Less.) Kuntze. 

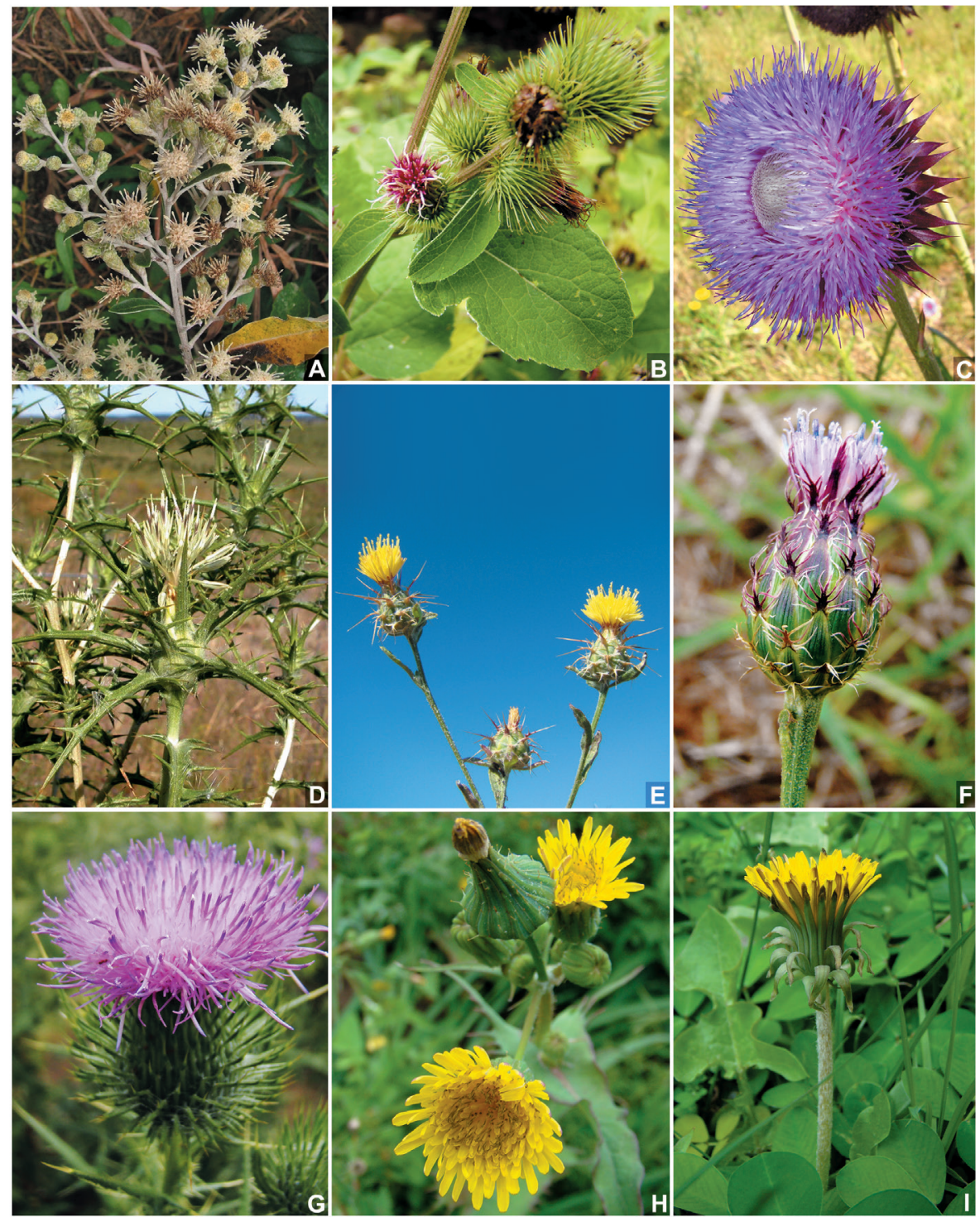

Figura 6. Tarchonantheae. A. Brachylaena discolor DC. Cardueae. B. Arctium lappa L.; C. Carduus nutans L.; D. Carthamus lanatus L.; E. Centaurea melitensis L.; F. Centaurea tweediei Hook. \& Arn.; G. Cirsium vulgare (Savi) Tem. Cichorieae. H. Sonchus oleraceus L.; I. Taraxacum officinale F.H. Wigg. 


\title{
TRIBO LIABEAE (CASS. EX DUMORT.) RYDB.
}

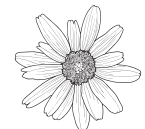 \\ Giselle Lopes Moreira \\ Cellini Castro de Oliveira
}

A história da classificação de Liabeae reflete a dificuldade de agrupamento dos seus táxons desde os naturalistas, entre eles, Cassini (1923), Bentham (1873) e Hoffmann (1890), que variavelmente trataram os grupos como membros de Vernonieae, Senecioneae, Heliantheae, Helenieae e Mutisieae.

Embora Rydberg (1927) tenha proposto formalmente o status de tribo para cinco gêneros (Liabum Adans, Sinclairiopsis Rydb., Megaliabum Rydb., Liabellum Rydb. e Sinclairia Hook. \& Arn.), trabalhos taxonômicos e florísticos (CARLQUIST, 1976; CRONQUIST, 1955) continuaram a adotar a classificação de Bentham, na qual a maioria dos táxons foi incluída apenas no gênero Liabum, tribo Senecioneae. A partir dos trabalhos conduzidos por Robinson (1983a, 1983b, 1990a, 1990b, 1994) e Robinson e Brettell (1973, 1974), a tribo Liabeae foi recircunscrita com o reconhecimento de três subtribos, 15 gêneros e cerca de 157 espécies.

Segundo Dillon e colaboradores (2009), Liabeae pode ser reconhecida por um conjunto de caracteres, tais como: presença de látex, folhas geralmente opostas, frequentemente trinervadas e alvo-tomentosas na face abaxial, capítulos radiados e heterógamos, corola das flores do raio e do disco comumente amarela, pápus geralmente duplo, série mais externa de escamas curtas e a mais interna de cerdas escabrosas e maiores.

Atualmente, Liabeae representa uma das menores tribos da família, com 18 gêneros e cerca de 165 espécies, com distribuição inteiramente neo- 
tropical, tendo o Peru como centro de diversidade, onde ocorrem 13 dos 18 gêneros reconhecidos (DILLON et al., 2009).

\section{Descrição}

Ervas ou arbustos perenes, algumas vezes escandentes ou pequenas árvores; látex geralmente presente. Folhas geralmente opostas, às vezes em rosetas, pecioladas, raramente sésseis, base foliar com pseudoestípulas ou disco nodal, venação trinervada, pinada ou palmada, alvo-tomentosas na face abaxial. Capitulescência simples ou subcimosa, às vezes formando uma panícula tirsoide; capítulos radiados, heterógamos; invólucro geralmente subimbricado, com brácteas em muitas séries graduadas; receptáculo alveolado, raramente paleáceo. Flores do raio geralmente presentes, pistiladas, corola amarela, ocasionalmente avermelhada a púrpura ou alva, estilete com ramos alongados. Flores do disco bissexuais, corola tubulosa, usualmente amarela, raramente vermelha, púrpura ou alva; anteras com apêndice do conectivo mais longo que largo, base da antera calcarada, algumas vezes caudada, fimbriada ou sagitada; estilete com base glabra e ápice piloso. Cipselas geralmente prismáticas, (2-4)5-10-costadas, geralmente com tricomas tectores e glandulares; pápus duplo, série mais externa menor, de escamas, e a mais interna de cerdas maiores, algumas vezes com cerdas plumosas ou pápus ausente.

No Brasil, há registro de apenas um gênero (Liabum) e duas espécies (Liabum acuminatum Rusby e L. amplexicaule Poepp.), ambas com ocorrência no Acre (BFG, 2015; DILLON et al., 2009).

\section{Literatura recomendada}

BENTHAM, G. Compositae. In: BENTHAM, G.; HOOKER, J. D. (Ed.). Genera Plantarum. London: Reeve, 1873, v. 2, n. 1, p. 163-533.

BRAZIL FLORA GROUP -BFG. Growing knowledge: an overview of seed plant diversity in Brazil. Rodriguésia, Rio de Janeiro, v. 66, n. 4, p. 1085-1113, 2015. 
CARLQUIST, S. Tribal interrelationships and phylogeny of the Asteraceae. Aliso, Claremont, v. 8, p. 465-492, 1976.

CASSINI, H. Liabum. In: CUVIER, G. (Ed.). Dictionnaire des Sciences Naturelles. 2 ème éd. Paris. Le Normant, 1823. v. 26, p. 203-211.

CRONQUIST, A. Phylogeny and taxonomy of the Compositae. American Midland Naturalist, Notre Dame, v. 53, p. 478-511, 1955.

DILLON, M. O. et al. Liabeae. In: FUNK, V. A. et al. (Ed.). Systematics, Evolution and Biogeography of Compositae. Vienna: IAPT, 2009. p. 417-438.

FUNK, V. A.; ROBINSON, H.; DILLON, M.O. Tribe Liabeae. In: KADEREIT, J. W.; JEFFREY, C. (Ed.). The Families and Genera of Vascular Plant: v. VIII: Flowering Plants Eudicots: Asterales. Berlin: Springer, 2007. p. 175-180. HOFFMANN, O. Compositae. In: ENGLER, A.; PRANTL, K. Die Natürlichen Pflanzenfamilien. Leipzig: W. Engelmann, 1890. v. 4, p. 87-391.

ROBINSON, H. A generic review of the tribe Liabeae (Asteraceae). Washington: Smithsonian Institution Press, 1983a. p. 1-69. (Smithsonian Institution Press, v. 54).

ROBINSON, H. Studies in the Liabeae (Asteraceae). XVI. New taxa from Peru. Phytologia, Huntsville, v. 54, p. 62-65, 1983b.

ROBINSON, H. Notes on Sinclairia and Liabellum in Mesoamerica (Liabeae: Asteraceae). Phytologia, Huntsville, v. 69, p. 57-60, 1990a.

ROBINSON, H. A redelimitation of Microliabum Cabrera (Asteraceae: Liabeae). Systematic Botany, Kent, v. 15, n. 4, p. 736-744, 1990b.

ROBINSON, H. New species of Ferreyranthus and Munnozia from Peru (Liabeae: Asteraceae). Phytologia, Huntsville, v. 76, p. 19-23, 1994.

ROBINSON, H.; BRETTELL, R. D. Tribal revisions in the Asteraceae. III. A new tribe, Liabeae. Phytologia, Huntsville, v. 25, p. 404-407, 1973.

ROBINSON, H.; BRETTELL, R. D. Studies in the Liabeae (Asteraceae). II. Preliminary survey of the genera. Phytologia, Huntsville, v. 28, p. 43-63, 1974.

RYDBERG, P. A. Carduaceae: Liabeae, Neurolaeneae, Senecioneae (pars). North American Flora, New York, v. 34, n. 4, p. 289-360, 1927. 


\title{
TRIBO VERNONIEAE CASS.
}

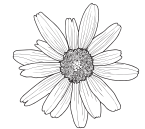 \\ Roberto Esteves \\ Benoit Loeuille \\ Jimi Naoki Nakajima \\ Danilo Marques \\ Polyana Soares \\ Vânia Esteves-Gonçalves \\ Cláudia Mendonça \\ Massimiliano Dematteis
}

A tribo Vernonieae possui uma distribuição pantropical, com grande parte das espécies concentradas no Brasil e África. Atualmente, são reconhecidas 21 subtribos, 126 gêneros e cerca de 1.300 espécies (KEELEY; ROBINSON 2009; ROBINSON, 2007).

A delimitação da tribo sofreu poucas mudanças desde o seu estabelecimento por Cassini (1816), exceto pela segregação da tribo Liabeae (ROBINSON, 1983) e Moquinieae (ROBINSON, 1994). Por outro lado, a classificação em subtribos e a circunscrição dos gêneros é bastante controversa (BREMER, 1994; ROBINSON, 1999), e boa parte dessa dificuldade taxonômica pode ser explicada pela definição do gênero Vernonia Schreb. Diversos autores aceitaram esse gênero como contendo cerca de 1.000 espécies, subdividido em inúmeras seções, subseções e séries (JONES,1979; HIND, 1993). Contudo, trabalhos mais recentes têm aceitado os gêneros reestabelecidos ou segregados a partir de Vernonia Schreb (ROBINSON, 1999, 2007; KEELEY; ROBINSON, 2009). De acordo com essa classificação, o gênero Vernonia é recircunscrito com 22 espécies no leste dos Estados Unidos, 5 espécies no México e 2 espécies ( $V$. echioides Less. e $V$. incana Less.) ocorrentes em áreas temperadas da América do Sul, incluído o Brasil (KEELEY; ROBINSON, 2009). 
A tribo Vernonieae pode ser caracterizada, em geral, por suas folhas alternas e capítulos homógamos, discoides, ramos do estilete com ápice agudo e com tricomas coletores estendendo-se abaixo da bifurcação, cipselas 3-20-costadas e pápus duplo, cerdoso ou paleáceo, raro coroniforme ou ausente (BREMER 1994; KEELEY; ROBINSON 2009). Os grãos de pólen são triaperturados (cólporos ou poros), geralmente com espinhos dispostos sobre muros em padrões regulares de lacunas (equinolofados) ou sem formar lacunas (subequinolofado) (JONES, 1979), raramente psilolofados (lacunas não ornadas por espinhos) (Apêndice A).

\section{Descrição}

Ervas perenes, raramente anuais, subarbustos a árvores ou lianas, raízes fibrosas ou com xilopódio lenhoso; ramos pubescentes ou glabros, frequentemente glanduloso-pontuados. Folhas alternas, às vezes rosulado -basais ou rosulado-suprabasais, raramente opostas ou verticiladas, sésseis ou pecioladas, inteiras ou serreado-denteadas, às vezes lobadas ou pinatissectas, pubescentes, às vezes glanduloso-pontuadas. Capitulescência corimbiforme, paniculiforme, escorpioide-cimoide, às vezes, capítulos isolados. Capítulos homógamos, discoides, flores 1-400, sésséis a pedunculados, livres ou mais raramente sincéfalos, com ou sem brácteas na base; invólucro campanulado, cilíndrico ou globoso, brácteas involucrais poucas a numerosas, multisseriadas, geralmente imbricadas, raramente uma única série; receptáculo plano ou levemente convexo, liso ou areolado, raramente alveolado, algumas vezes paleáceo ou com fimbrias. Flores bissexuais, raramente unissexuais, corola tubulosa, 5-lobada, raramente 3-4-lobada, lobos glabros ou pubescentes (Figura 7C), actinomorfa ou raramente zigomorfa, púrpura-magenta a alva ou lavanda, raro creme, avermelhada ou amarelada, frequentemente glandulosa, às vezes pubescente; anteras com apêndice do conectivo plano, alongado, ápice obtuso, raramente glanduloso, calcaradas (Figura 7G), base sagitada, obtusa ou aguda, às vezes curtamente caudada; ramos do estilete semicilíndricos, ápice agudo, raro obtuso, às vezes encurvados, com pilosidade estendendo abaixo do ponto de bifurcação, raro glabros, superfície interna com papilas estigmáticas, base do estilete frequentemente com nódulo basal. Cipselas oblongas a 
obovoide-obcônicas, cilíndricas ou levemente achatadas, 3-20-costadas, setulíferas, algumas vezes glanduloso-pontuadas; pápus cerdoso, 1 a várias séries, comumente duplo (os elementos nas 2 séries são geralmente diferentes no comprimento, forma ou ambos), com a série externa mais reduzida, elementos cerdosos capilares ou barbelados, escamiformes, paleáceos (achatados ou espiralados), raro coroniforme.

No Brasil, essa tribo é a $2^{\mathrm{a}}$ mais diversa em número de gêneros e espécies (51 gêneros e 459 espécies). Muitos gêneros e espécies são endêmicos (24 gêneros e 347 espécies), com ocorrência em todos os domínios fitogeográficos brasileiros. (BFG, 2015) Representantes de Vernonieae são encontrados nas Figuras 10, 11 e 12.

\section{Chave de identificação para os gêneros de Vernonieae no Brasil}

1. Cipselas comprimidas, atenuadas em direção à base; pápus com 1 par de aristas mais longas e 4 mais curtas (Figura 9C). Trichospira

1'. Cipselas cilíndricas; pápus variado ou ausente 2

2. Plantas com folhas geralmente em roseta; corola fortemente zigomorfa com uma incisão profunda em um dos lobos (Figuras 7K e 8H); pápus geralmente paleáceo e longo-aristado 3 2'. Plantas geralmente com entrenós conspícuos, exceto pela forma de vida caulirosulada (Figura 8G); corola actinomorfa ou levemente zigomorfa, sem uma incisão profunda em um dos lobos (Figura 7C); pápus variado. 5

3. Pápus com 5 ou mais páleas longo-aristadas, desiguais entre si, contorcidas ou uncinadas (Figura 8I). Pseudelephantopus 3'. Pápus com cerdas ou páleas longo-aristadas, subiguais, retas 4

4. Capítulos em glomérulos bracteados; cipselas 10-costadas; pápus unisseriado, paleáceo, 5-8 páleas longo-aristadas (Figura 7L), raramente curtas Elephantopus 4'. Capitulescência espiciforme; cipselas 5-costadas; pápus 2-3-seriado, cerdoso e paleáceo, cerdas numerosas, as mais internas paleáceas e longoaristadas Orthopappus 
5. Capítulos compostos, ou seja, agrupados em glomérulos (Figura 7F) ou espigas, livres entre si (capitulescência de $2^{\mathrm{a}}$ ou $3^{\mathrm{a}}$ ordem) ou fundidos (sincefalia) (Figuras 8F e 9E), mas não em ramos cimosos 6 5'. Capítulos simples, ou seja, solitários, ou organizados em cimeiras (paniculiformes, espiciformes, corimbiformes, escorpioides) (Figuras 7J e 9D) 22

6. Ervas ou subarbustos; capítulos com 4 flores, folhas caulinares 7

6'. Hábitos diversos; capítulos com números de flores diversos; se 4, então arvoretas ou subarbustos com folhas em roseta basal 9

7. Folhas com venação secundária paralelinérvea; capítulos circundados pelas folhas apicais dos ramos; brácteas involucrais cerca de 12; pápus unisseriado, aristado; grão de pólen equinolofado, tricolporado .... Soaresia 7'. Folhas com outros tipos de nervação; capitulescência de $2^{\mathrm{a}}$ ordem envolvida por brácteas involucrais (Figuras 1E e 8F); brácteas involucrais 4; pápus duplo ou pápus unisseriado e paleáceo; grão de pólen equinolofado, triporado ou porado. 8

8. Cipselas 5-costadas, pápus duplo, com a série externa de páleas curtas e largas, geralmente avermelhadas, e a interna de cerdas lineares, longas (Figura 7E); grão de pólen equinolofado, porado Caatinganthus 8'. Cipselas 8-costadas; pápus unisseriado de escamas laciniadas; pólen triporado Telmatophila

9. Ramos e eixo da capitulescência frequentemente com alas decorrentes; pólen não lofado. Gorceixia

9'. Ramos e eixos da capitulescência cilíndricos; pólen lofado 10

10. Capítulos axilares; invólucro com 2 brácteas lanceoladas, cimbiformes; 1 flor por capítulo; pápus coroniforme de páleas curtas, laceradas (Figura 8J) Rolandra

10'. Capítulos geralmente terminais; invólucro com mais de 2 brácteas; comumente mais de 1 flor por capítulo; pápus geralmente paleáceo ou cerdoso 11 
11. Subarbustos escaposos ou arbustos com folhas em roseta basal (caulirosuladas) (Figura 8G); capitulescência escaposa bracteada ............. 12 11'. Arbustos ou subarbustos, raramente árvores com folhas ao longo dos ramos; capitulescência em ramos terminais ou axilares.............................. 15

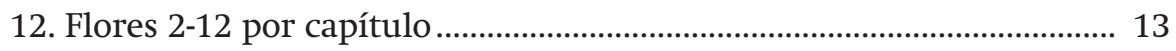

12'. Flores 20-100 por capítulo......................................................................... 14

13. Subarbustos escaposos; capítulos agrupados em glomérulos, subumbelas ou espigas, não envolvidos por brácteas involucrais de $2^{\mathrm{a}}$ ordem, longo-pedunculados (Figura 7F); pápus cerdoso, duplo, série mais externa menor e paleácea e mais interna cerdosa Chresta 13'. Plantas caulirosuladas; capítulos curto-pedunculados e dispostos em sincéfalo, envolvido por brácteas involucrais de $2^{\mathrm{a}}$ ordem; pápus 2-3-seriado, simples, cerdas subiguais

Prestelia

14. Indumento das folhas composto de tricomas em "T" inflado (Figura 8E); ápice das brácteas involucrais obtuso a agudo; 20-50 flores; pápus de cerdas Minasia 14'. Indumento das folhas composto de tricomas não ramificados; ápice das brácteas involucrais espinescente; 80-100 flores; pápus de poucas aristas decíduas Proteopsis

15. Capítulos aglomerados, dispostos em glomérulos ou espigas

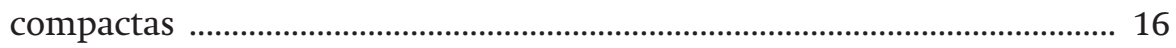

15'. Capítulos dispostos em sincéfalos (Figuras 1E, F, 8F e 9E) .................... 19

16. Arbustos ou arvoretas; capitulescência em ramos terminais................ 17

16'. Subarbustos; capitulescência em ramos axilares................................... 18

17. Margem da lâmina plana; pápus (2)3-5 séries, simples (todos os elementos cerdosos, igual ou subigual no comprimento), série interna não espiralada Eremanthus

17’. Margem da lâmina revoluta; pápus 1-2 séries, duplo, série mais interna geralmente espiralada Lychnophora 
18. Folha com face adaxial não muricada (lisa), tricomas simples; capítulos em glomérulos pedunculados; cipselas seríceas Vinicia 18'. Folha com face adaxial muricada (rugosa), tricomas armados ou simples, multicelulares (Figura 7H); capítulos em glomérulos sésseis; cipselas glabras Chronopappus

19. Folhas com bainha semiamplexicaule (Figura 8L) a amplexicaule (Figura 8M); capitulescência em ramos axilares 20 19'. Folhas sem bainha (Figura 8K); capitulescência em ramos terminais .... Eremanthus

20. Sincéfalo de $3^{\mathrm{a}}$ ordem (Figuras 1F e 9E); pápus duplo, com a série externa escamiforme ou ausente ou, ainda, coroniforme, a interna de páleas longas, achatadas, espiraladas, caducas; ápice das cerdas da série interna do pápus acuminado Lychnophora 20 '. Sincéfalo de $2^{\mathrm{a}}$ ordem (Figura 1E e $8 \mathrm{~F}$ ), pápus duplo, com a série externa de páleas curtas e a interna geralmente de cerdas longas (Figura 7D), raramente espiraladas, ápice das cerdas da série interna do pápus agudo ...

21. Hábito simpodial; indumento composto de tricomas com 3-5 braços; sincéfalo longo pedunculado, geralmente pendente na maturidade

Paralychnophora

21'. Hábito monopodial; indumento composto de tricomas em "T"; sincéfalo séssil (Figura 7B)

Maschalostachys

22. Brácteas involucrais externas foliáceas; corola com tricomas glandulares longo estipitados Centratherum 22'. Brácteas involucrais externas nunca foliáceas; corola sem tricomas glandulares, longo estipitados 23

23. Brácteas subinvolucrais conspícuas; receptáculo paleáceo ou fimbriado (Figura 7M) 24 23'. Brácteas subinvolucrais inconspícuas ou ausentes; receptáculo sem páleas e raramente com fímbrias 26 
24. Folhas sem bainha; capítulos solitários; bráctea subinvolucral trinérvia Hololepis

24'. Folhas com bainha semi a amplexicaule (Figuras 8L-M); capítulos aglomerados ou paniculiformes; brácteas subinvolucral peninérvia ....... 25

25. Folhas sésseis, superfície adaxial da lâmina bulada; cipselas com fitomelanina, glabras. Heterocoma 25'. Folhas pecioladas, superfície adaxial da lâmina lisa; cipselas sem fitomelanina, pubescentes Anteremanthus

26. Ramos com tricomas estrelados ou com 3-5 braços, inflados (Figura 7H) ou não, raramente simples 27

26'. Ramos com tricomas simples ou em "T" (Figura 8E) 32

27. Indumento com tricomas longos, escuros, multicelulares, intercalados com tricomas estrelados; brácteas involucrais internas persistentes; receptáculo fimbriado. Blanchetia 27'. Indumento variado sem os tricomas longos, escuros, multicelulares; brácteas involucrais internas decíduas; receptáculo não fimbriado 28

28. Folhas com bainha em almofada (Figura 8K); capítulos solitários ou poucos em aglomerados terminais. Piptolepis 28'. Folhas sem bainha; capitulescência terminal paniculiforme ou aglomerados axilares.

29. Capitulescência paniculiforme; estilete com nódulo basal; pápus persistente 30 29'. Capitulescência corimbiforme ou eixos reflexos; estilete sem nódulo basal; pápus interno decíduo 31

30. Ramos e folhas com tricomas estrelados; somente as brácteas involucrais mais internas decíduas; anteras, quando caudadas, com células não esclerificadas e muitas vezes distintamente dentadas Critoniopsis 30'. Ramos e folhas com tricomas estrelados ou lepidotos; a maioria das brácteas involucrais decíduas; anteras caudadas com células esclerificadas Piptocarpha 
31. Árvores ou arvoretas; invólucro cilíndrico a campanulado; brácteas involucrais sem bordos escariosos; flores 1-5 Piptocoma 31'. Ervas aquáticas; invólucro ovoide; brácteas involucrais com bordo escarioso; flores 50

Pacourina

32. Cipselas isomórficas, todas prismáticas 33 32'. Cipselas dimórficas, as mais externas aladas e as mais internas prismáticas 52

33. Capítulos com todas as flores zigomorfas ou raramente actinomorfas apenas no centro do capítulo (Figura 8D) Mattfeldanthus

33'. Capítulos com todas as flores actinomorfas (Figura 9A) 34

34. Pápus formando um tubo crasso ou paleáceo, com aproximadamente metade do comprimento da cipsela (Figura 9B) Struchium 34'. Pápus constituído de cerdas, páleas livres ou aristas, nunca formando um tubo 35

35. Ramos, folhas, brácteas involucrais, corola e cipselas densamente rubroglanduloso-pontuadas; grão de pólen equinolofado, porado.... Acilepidopsis 35'. Ramos, folhas, brácteas involucrais, corola e cipselas sem pontuações ou com pontuações de outras cores, nunca vermelhas; grão de pólen de outras formas 36

36. Brácteas involucrais concrescidas na base; receptáculo com alvéolos profundos, que envolvem quase completamente as cipselas (Figura 7A); cipselas seríceas e glanduloso-pontuadas. Albertinia 36'. Brácteas involucrais livres; receptáculo não ou superficialmente alveolado; cipselas glabras ou não. 37

37. Lobos da corola mais curtos ou do mesmo tamanho que o limbo

Cololobus 37'. Lobos da corola nitidamente maiores que o limbo (Figura 8A) 38

38. Capitulescência densamente cimoso-escorpioide (cíncino), com o ápice geralmente curvado (Figura 7J); grão de pólen subequinolofado

Cyrtocymura

38'. Capitulescência em cimeira seriada, cimeira tirsoide, corimbiforme ou paniculiforme, grãos de pólen de outras formas. 39 
39. Capitulescência em cimeira simples ou corimbiforme, nunca fortemente seriada, ou paniculiforme; pólen equinado (raramente lofado) ................. 40 39'. Capitulescência frequentemente cimosa-seriada ou capítulos em série na base de brácteas axilares, algumas vezes individualmente pedunculados; pólen geralmente lofado........................................................................... 44

40. Capitulescência paniculiforme …………………………………………... 41

40'. Capitulescência não paniculiforme (Figura 9D) ..................................... 42

41. Arvoretas a árvores; brácteas involucrais internas decíduas; anteras com base longo-caudada Gymnanthemum 41'. Ervas anuais; brácteas involucrais internas persistentes; anteras ecaudadas. Cyanthillium

42. Ervas com base decumbente; capitulescência cimosa com os ramos mais longos que o eixo central Vernonia 42'. Plantas com base ereta; capitulescência mais complexa, ramos cimosos, tirsoides ou corimbiformes 43

43. Plantas herbáceas; limbo da corola com tricomas internos; anteras com base sagitada ou aguda; cipselas com ráfides alongadas Dasyanthina 43'. Plantas lenhosas; limbo da corola sem tricomas internos; anteras com base caudada; cipselas com ráfides subquadradas Vernonanthura

44. Pápus paleáceo, páleas planas ou pápus aristado 45

44'. Pápus cerdoso ou somente a série externa paleácea e curta 47

45. Plantas terrestres; receptáculo alveolado circundado por aristas longas e fimbriadas (Figura $8 \mathrm{~N}$ ), base das anteras calcarada (Figura 80); pápus paleáceo (Figura 8P) 46 45'. Plantas aquáticas; receptáculo não fimbriado, base das anteras não calcarada; pápus com cerca de 10 aristas rígidas, espessadas na base e progressivamente estreitadas em direção ao ápice.

Xiphochaeta

46. Ervas; lâmina foliar membranácea; capítulos com 30-50 flores; pólen porado. Stilpnopappus 46'. Subarbustos ou arbustos; lâmina foliar coriácea; capítulos com 6-12 flores; pólen tricolporado Strophopappus 
47. Brácteas involucrais equinadas; pápus alaranjado quando jovem

Echinocoryne

47’. Brácteas involucrais adpressas a esquarosas; pápus de outras cores .......

48. Capítulos estreitamente cilíndricos; flores 4-10.

Stenocephalum

48'. Capítulos campanulados ou cilíndrico-campanulados; geralmente mais de 10 flores

49. Capítulos pedunculados ou sésseis em cimeiras seriadas; pólen equinolofado, tricolporado 50

49'. Capítulos sésseis localizados no meio dos entrenós, nunca em cimeiras seriadas; pólen psilofado, porado Mesanthophora

50. Brácteas subinvolucrais menores que os capítulos ou ausentes; apêndice das anteras geralmente com glândulas (Figura 7I); cipselas com pontuações glandulares entre os tricomas; pólen com 2 lacunas polares e sem lacuna equatorial.

Chrysolaena

50’. Brácteas subinvolucrais foliáceas geralmente maiores que os capítulos; apêndice das anteras sem glândulas; cipselas sem pontuações glandulares entre os tricomas; pólen com lacuna equatorial 51

51. Capítulos geralmente menores que $1 \mathrm{~cm}$ diâm., sésseis; corola com lobos com tricomas tectores; base do estilete alargada (Figura 8B).

Lepidaploa

51'. Capítulos geralmente maiores que $1 \mathrm{~cm}$ diâm., sésseis a pedunculados; corola com lobos geralmente glandulosos; base do estilete cilíndrica (Figura $8 \mathrm{C})$ Lessingianthus

52. Capitulescência cimosa; invólucro com 6 séries de brácteas livres; capítulo com 60-70 flores; grão de pólen triporado Heterocypsela 52'. Capitulescência em glomérulos ou pequenas espigas (Figura 10A); invólucro com uma série de brácteas completamente fusionadas; capítulo com 6 flores; grão de pólen tricolporado Allocephalus 


\section{Literatura recomendada}

BARROSO, G. M. Sistemática de Angiospermas do Brasil. Viçosa: UFV, 1991. v. 3.

BRAZIL FLORA GROUP - BFG. Growing knowledge: an overview of seed plant diversity in Brazil. Rodriguésia, Rio de Janeiro, v. 66, n. 4, p. 10851113, 2015.

BREMER, K. Asteraceae: cladistics and classification. Portland: Timber Press, 1994.

CASSINI, H. Tableau exprimant les affinités des tribus naturelles de familie des Synanthérées. In: CUVIER, G. (Ed.). Dictionnaire des Sciences Naturelles, Paris: Le Normant, 1816. v. 3.

HIND, D. J. N. Notes on the Compositae of Bahia, Brazil: I. Kew Bulletin, London, v. 48, n. 2, p. 245-277, 1993.

JONES, S. B. Synopsis and pollen morphology of Vernonia (Compositae: Vernonieae) in the New World. Rhodora, Cambridge, v. 81, p. 425-447, 1979.

KEELEY, S.; ROBINSON, H. Vernonieae. In: FUNK, V. et al. (Ed.). Systematics, Evolution, and Biogeography of Compositae. Vienna: IAPT, 2009. cap. 28. p. $439-470$.

LORENCINI, T. S. et al. Estudos taxonômicos do gênero Echinocoryne H. Rob. (Asteraceae, Vernonieae) no Brasil. Iheringia: Série Botânica, Porto Alegre, v. 72, n. 1, p. 16-32, 2017.

ROBINSON, H. Generic and subtribal classification of American Vernonieae.

Washington: Smithsonian Institution Press, 1999. p. 1-116. (Smithsonian Institution Press, v. 89).

ROBINSON, H. A generic review of the tribe Liabeae (Asteraceae). Washington: Smithsonian Institution Press, 1983. p. 1-6. (Smithsonian Institution Press, v. 54). 
ROBINSON, H. Notes on the tribes Eremothamneae, Gundelieae and Moquinieae, with comparisons of their pollen. Taxon, Utrecht, v. 43, n. 1, p. 33-44, 1994.

ROBINSON, H. Vernonieae. In: KADEREIT, J. W.; JEFFREY, C. (Ed.). The Families and Genera of Vascular Plants: v. 8: Flowering Plants: Eudicots Asterales. Berlin: Springer, 2007. v. VIII, p. 149-174.

ROBINSON, H.; BOHLMANN, F.; KING, R. M. Chemosystematic notes in the Asteraceae, III: natural subdivisions of the Vernonieae. Phytologia, [Huntsville,] v. 46, p. 421-436, 1980. 

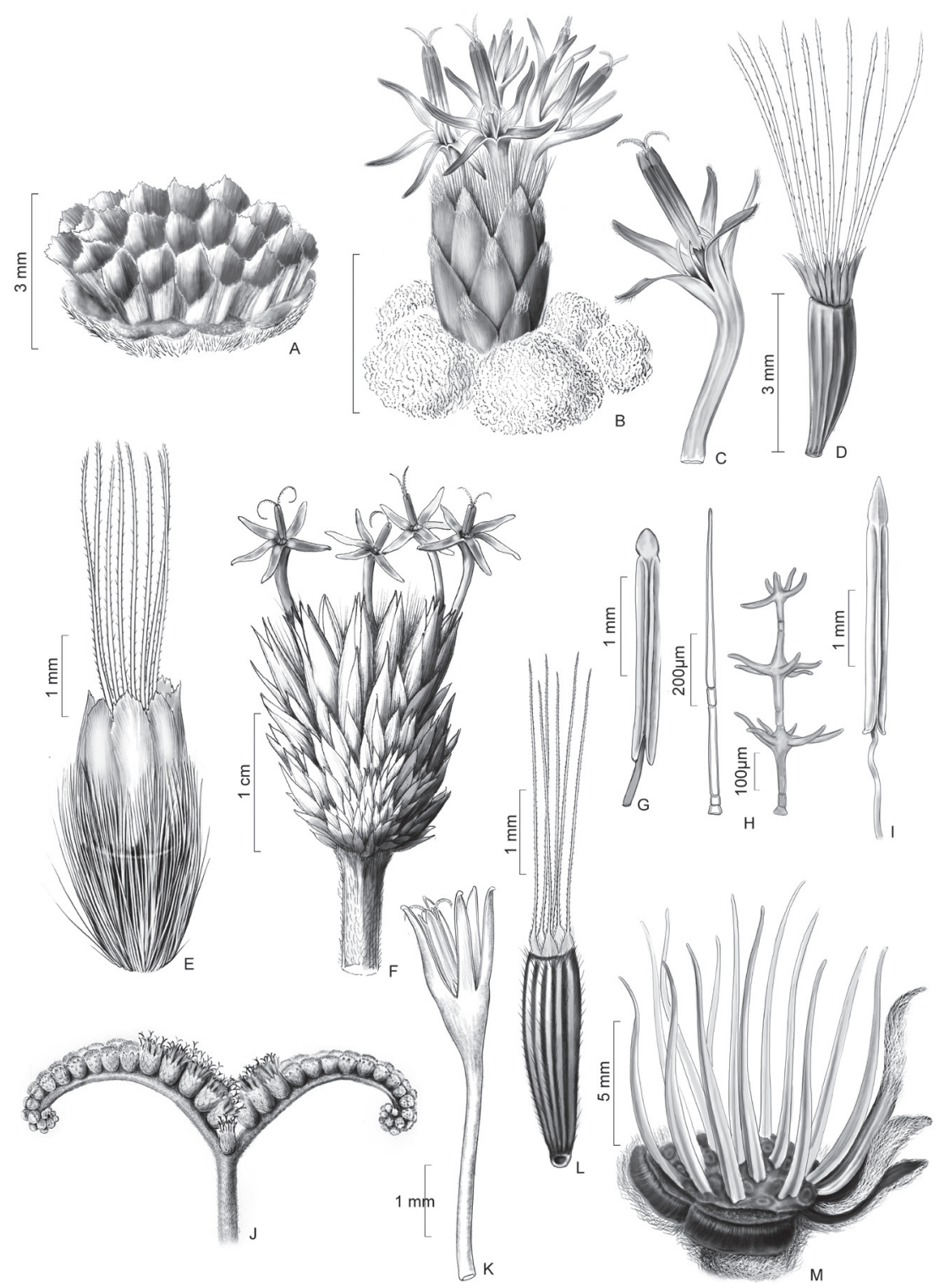

Figura 7. Vernonieae. A. Receptáculo alveolado de Albertinia brasiliensis Spreng.; B-D. Maschalostachys mellosilvae Loeuille \& Roque: B. Capítulo; C. Corola, estames e ramos do estilete; D. Cipsela e pápus duplo; E. Cipsela e pápus duplo de Caatinganthus rubropappus (Soar. Nunes) H. Rob.; F-G. Chresta harleyi H. Rob.: F. Capitulescência congesta; G. Antera calcarada (base arredondada); H. Tricomas de Chronopappus bifrons (DC. ex Pers.) DC.; I. Antera de Chrysolaena platensis (Spreng.) H. Rob.; J. Capitulescência em cimeira seriada de Cyrtocymura harleyi (H. Rob.) H. Rob.; K-L. Elephantopus mollis Kunth: K. Corola; L. Cipsela e pápus; M. Receptáculo paleáceo de Heterocoma erecta (H. Rob.) Loeuille, J.N. Nakaj. \& Semir. 


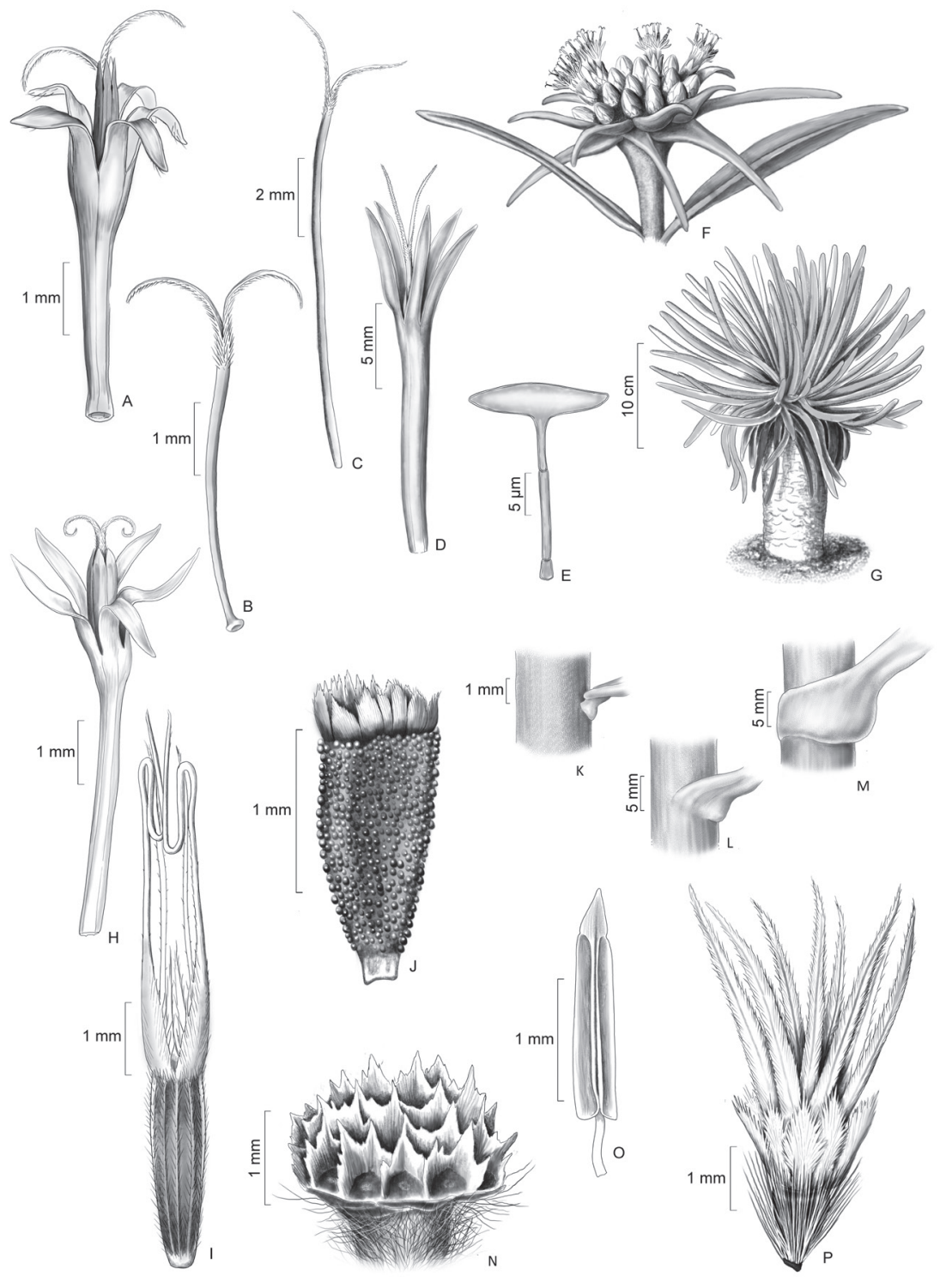

Figura 8. Vernonieae. A-B. Lepidaploa cotoneaster (Willd. ex Spreng.) H. Rob.: A. Corola com tricomas na lacínias, estames e ramos do estilete; B. Estilete com pilosidade estendendo abaixo da bifurcação, base alargada. C. Estilete (base cilíndrica) de Lessingianthus asteriflorus (Mart. ex DC.) H. Rob.; D. Corola de Mattfeldanthus mutisioides H. Rob. \& R.M. King; E. Tricoma em forma de "T" inflado de Minasia alpestris (Gardner) H. Rob.; F. Sincefalia de $2^{\mathrm{a}}$ ordem de Paralychnophora atkinsiae D.J.N. Hind; G. Forma de vida caulirosulada de Proteopsis argentea Mart. \& Zucc. ex Sch. Bip.; H-I. Pseudelephantopus spicatus (Juss. ex Aubl.) C.F. Baker: H. Corola, estames e ramos do estilete; I. Cipsela e pápus; J. Cipsela e pápus de Rolandra fruticosa (L.) Kuntze. K-M. Bainha foliar em Lychnophorineae: K. bainha em almofada (pad like); L. bainha semiamplexicaule; M. bainha amplexicaule. N-P. Stilpnopappus tomentosus Mart. ex DC.: N. Receptáculo alveolado, com ápice aristado; O. Estame; P. Cipsela e pápus duplo. 


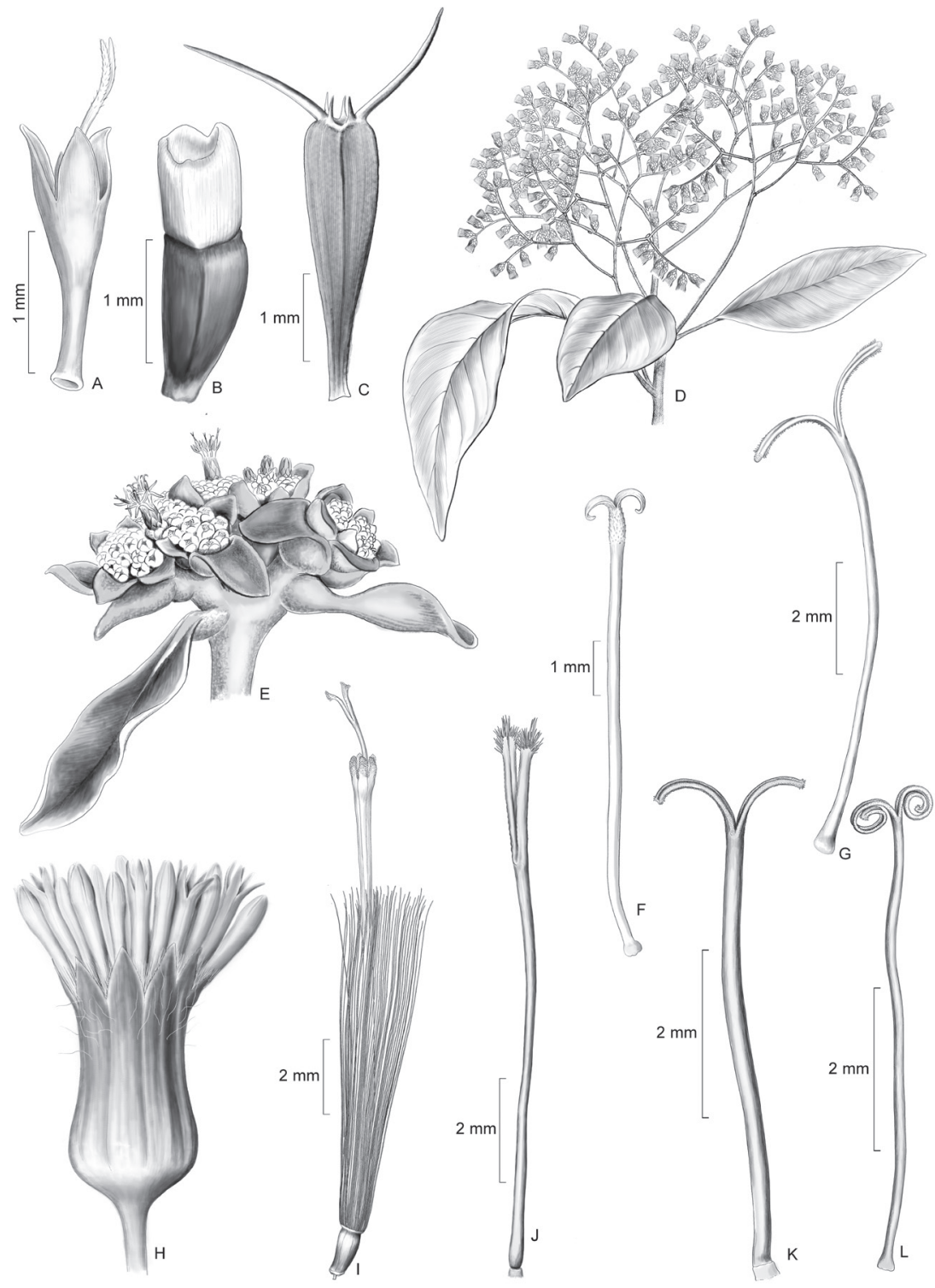

Figura 9. Vernonieae. A-B. Struchium sparganophorum (L.) Kuntze: A. Corola e ramos do estilete; B. Cipsela e pápus coroniforme; C. Cipsela e pápus de Trichospira verticillata (L.) S.F. Blake; D. Capitulescência (arranjo dos capítulos de $1^{a}$ ordem) de Vernonanthura divaricata (Spreng.) H. Rob.; E. Sincefalia com capítulos de

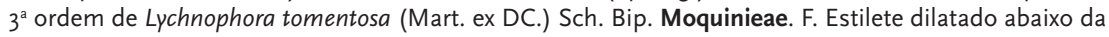
bifurcação de Moquinia racemosa (Spreng.) DC. Senecioneae. G. Estilete de Dendrophorbium pellucidinerve (Sch. Bip. ex Baker) C. Jeffrey; H. Capítulo com invólucro unisseriado de Emilia fosbergii Nicolson; I.

Flor da margem (filiforme e feminina) de Erechtites hieracifolius (L.) Raf. ex DC.; J. Estilete de Graphistylis riopretensis A.M. Teles \& B. Nord.; K. Estilete de Pentacalia desiderabilis (Vell.) Cuatrec.; L. Estilete de Senecio hemmendorffi Malme. 

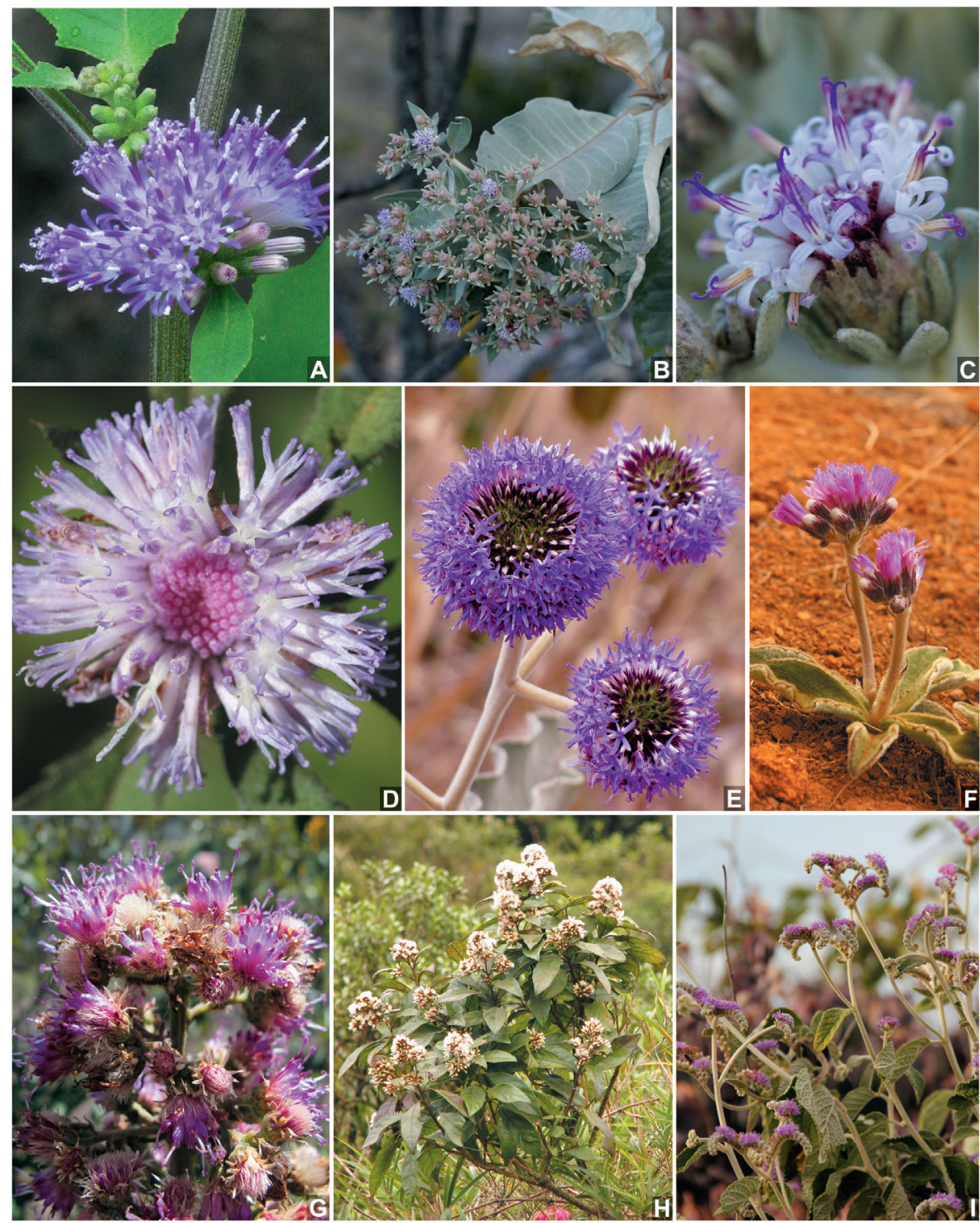

Figura 10. Vernonieae. A. Allocephalus gamolepis Bringel Jr., J.B.A., J.N. Nakaj. \& H. Rob.; B-C. Anteremanthus piranii Roque \& F.A. Santana; D. Centratherum punctatum Cass.; E. Chresta sphaerocephala DC.; F. Chrysolaena obovata (Less.) M. Dematt.; G. Cololobus rupestris (Gardner) H. Rob.; H. Critoniopsis quinqueflora (Less.) H. Rob.; I. Cyrtocymura harleyi (H. Rob.) H. Rob. 

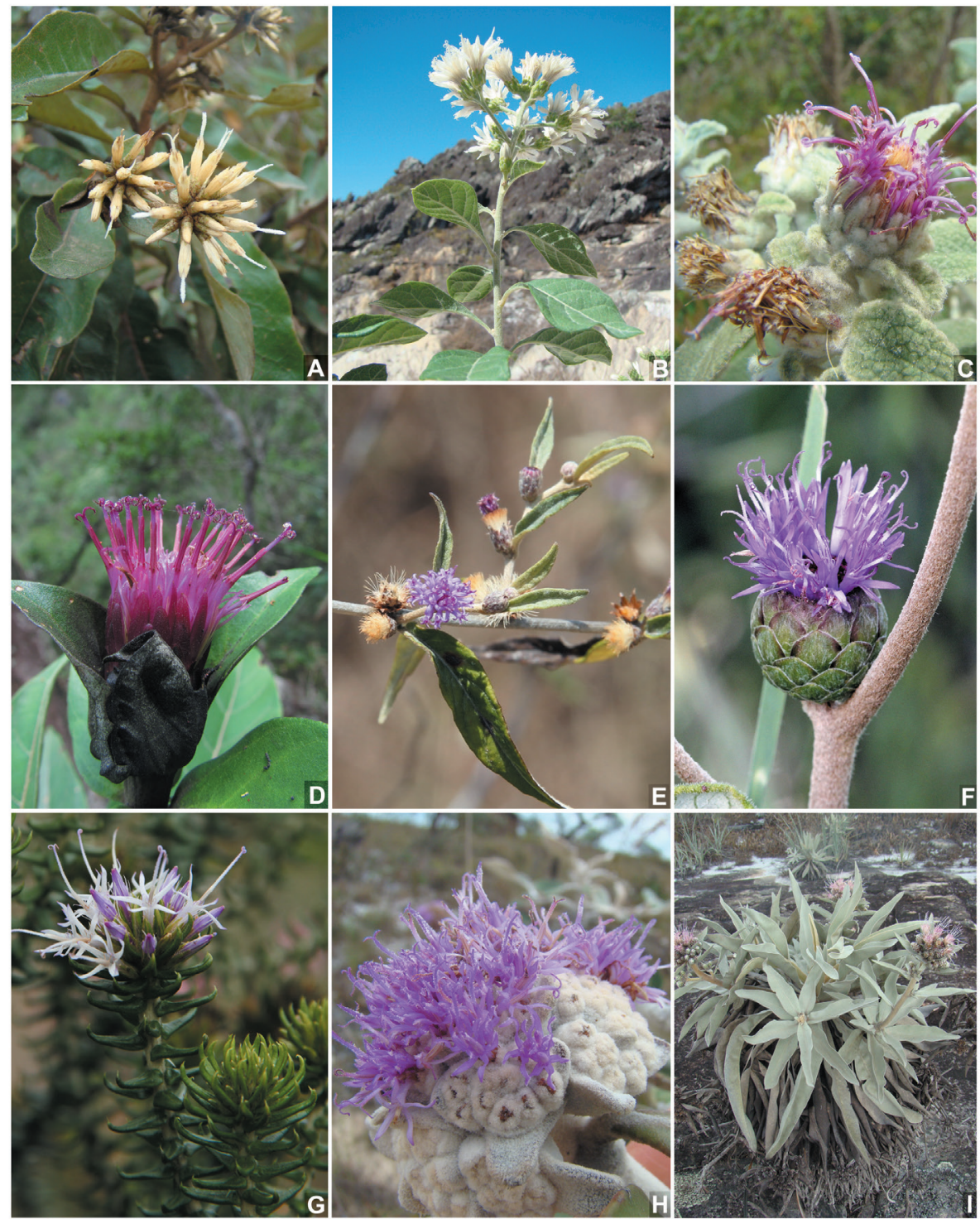

Figura 11. Vernonieae. A. Eremanthus glomerulatus Less.; B. Gymnanthemum amygdalinum (Delile) Sch. Bip. ex Walp.; C. Heterocoma erecta (H. Rob.) Loeuille, J.N. Nakaj. \& Semir; D. Hololepis pedunculata (DC. ex Pers.) DC.; E. Lepidaploa cotoneaster (Willd. ex Spreng.) H. Rob.; F. Lessingianthus monocephalus (Gardner) H. Rob.; G. Lychnophora granmogolensis (Duarte) D.J.N. Hind; H. Lychnophora tomentosa (Mart. ex DC.) Sch. Bip.; I. Minasia alpestris (Gardner) H. Rob. 


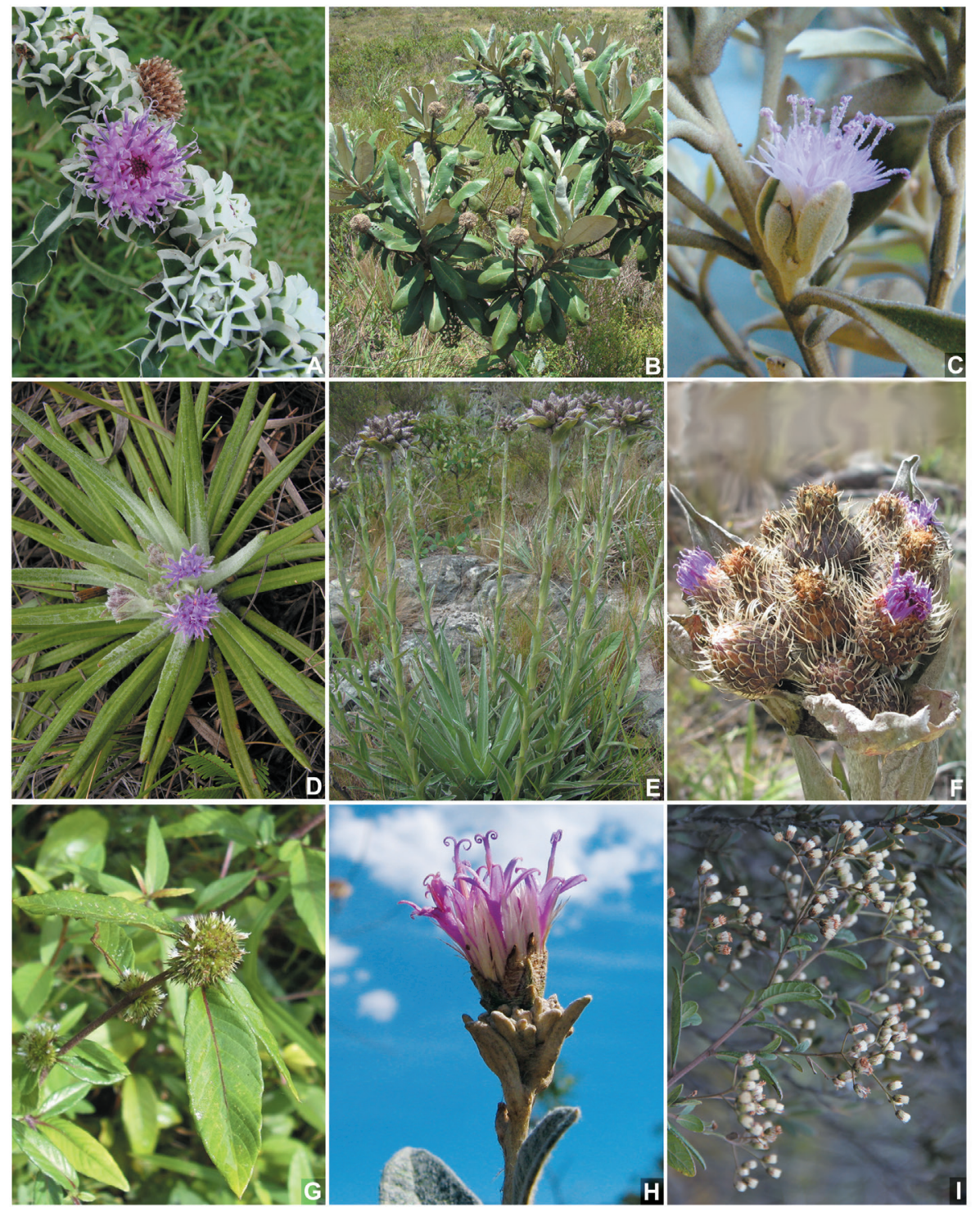

Figura 12. Vernonieae. A. Pacourina edulis Aubl.; B. Paralychnophora harleyi (H. Rob.) D.J.N. Hind; C.

Piptolepis campestris Semir \& Loeuille; D. Prestelia eriopus Sch. Bip.; E-F. Proteopsis argentea Mart. \& Zucc. ex Sch. Bip.; G. Rolandra fruticosa (L.) Kuntze; H. Strophopappus glomeratus (Gardner) R. Esteves; I. Vernonanthura brasiliana (L.) H. Rob. 


\section{TRIBO MOQUINIEAE H. ROB.}

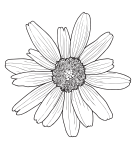

Helen A. Ogasawara

Nádia Roque

Robinson (1994) reestabeleceu Moquinia DC., anteriormente pertencente à tribo Mutisieae (CABRERA, 1969), e Pseudostifftia H. Rob., gênero descrito em Vernonieae (ROBINSON, 1979, 1980), situando-os em uma nova tribo, Moquinieae. Recentemente, os estudos de filogenia molecular e caracteres morfológicos (ramos do estilete curtos, espessos e papilosos na região abaixo do ponto de bifurcação e grãos de pólen com superfície equinada com espinhos longos) confirmaram a posição da tribo Moquinieae próxima, porém separada, de Vernonieae (ROBINSON, 2007, 2009). Na atual classificação, a tribo Moquinieae, juntamente a Arctoideae, Cichorieae, Eremonthamneae, Liabeae, Platycarpheae e Vernonieae, compõe a subfamília Cichorioideae (FUNK et al., 2009).

\section{Descrição}

Arbustos ou arvoretas, monoicos ou ginodioicos (Moquinia). Folhas simples, alternas, lâmina foliar com ápice arredondado a retuso, margem inteira, base cuneada, tomentosa, lepidota, tricomas glandulares sésseis, curto-pecioladas. Capitulescência piramidalmente tirsoide, ramos racemiformes, espiciformes ou corimbiformes, terminal; receptáculo epaleáceo. Capítulos discoides, homógamos, curto-pedunculados ou sésseis, cilíndricos, brácteas involucrais em 4-5 séries, graduadas, internas decíduas. Flores 1-5, corola actinomorfa, rósea, alva ou lilás, tubo da corola hipocraterifor- 
me, com tricomas glandulares externamente, 5 lobos, lineares; anteras calcaradas, curto-caudadas, apêndice do conectivo da antera 3-4 vezes tão longo quanto largo, estames abortados nas flores funcionalmente femininas; estilete curtamente bilobado, ápice arredondado a obtuso, espessado e escabroso abaixo da bifurcação (Figura 9F), estilopódio presente. Cipselas cilíndricas, 10-17-costadas, estrigosas, carpopódio anuliforme; pápus com cerca de 2 séries, cerdas 20-90, simples, série externa irregularmente mais curta, alvo ou ocre.

Moquinieae está representada por 2 gêneros, Moquinia e Pseudostifftia, ambos monoespecíficos (ROBINSON, 2009) e de distribuição restrita ao Brasil. As 2 espécies, M. racemosa (Spreng.) DC. (Figura 14A) e P. kingii H. Rob. (Figuras 14B-C), estão distribuídas nos estados da Bahia e Minas Gerais, principalmente na Cadeia do Espinhaço, em áreas de cerrado, nas fitofisionomias de campos gerais e campos rupestres.

\section{Chave de identificação para os gêneros de Moquinieae no Brasil}

1. Lâmina foliar alvo-tomentosa na face abaxial, discolor, ramos cinéreos; capitulescência dupla racemiforme ou espiciforme, flores 3-5, corola rósea a alva, pápus ocre. Moquinia

1'. Lâmina foliar glabra, concolor, ramos castanhos, ferrugíneos; capitulescência paniculiforme, flor 1, corola lilás, pápus alvo Pseudostifftia

\section{Literatura recomendada}

CABRERA, A. L. El genero Moquinia (Compositae). Boletin de la Sociedad Argentina de Botanica, La Plata, v. 11, p. 255-264, 1969.

CANDOLLE, A. P. de. Prodromus Systematis Naturalis Regni Vegetabilis. Paris: Treuttel \& Würtz, 1838. v. 7. 
FUNK, V. et al. Compositae metatrees: the next generation. In: FUNK, V. A. et al. (Ed.). Systematics, Evolution and Biogeography of Compositae. Vienna: IAPT, 2009. Chapt. 44, p. 749-765.

GAMERRO, J. C. Identidad de Pseudostifftia con Moquinia (Compositae) y consideraciones sobre la ubicación tribal del taxon. Darwiniana, Buenos Aires, v. 30, n. 1-4, p. 123-136, 1990.

ROBINSON, H. Moquinieae. In: KADEREIT, J. W.; JEFFREY, C. (Ed.). Families and Genera of Vascular Plants: v. VIII: Flowering Plants. Eudicots. Asterales. Berlin Springer-Verlag, 2007. p. 148-149

ROBINSON, H. Moquinieae. In: FUNK, V. A. et al. (Ed.). Systematics, Evolution and Biogeography of Compositae. Vienna: IAPT, 2009. Chapt. 30, p. 477-481.

ROBINSON, H. Notes on the tribes Eremothamneae, Gundelieae and Moquinieae, with comparisons of their pollen. Taxon, Utrecht, v. 43, n. 1, p. 33-44, 1994.

ROBINSON, H. Two new genera of Vernonieae (Asteraceae) from Brazil, Heterocypsela and Pseudostifftia. Phytologia, Huntsville, v. 44, p. 442-450, 1979.

ROBINSON, H.; BOHLMANN, F.; KING, R. M. Chemosystematic notes on the Asteraceae. III. Natural subdivisions of the Vernonieae. Phytologia, Huntsville, v. 46, p. 421-436, 1980. 


\title{
TRIBO SENECIONEAE CASS.
}

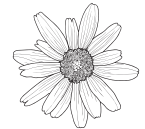 \\ Aristônio M. Teles \\ Fernanda Santos Freitas
}

Senecioneae Cass. é a maior tribo de Asteraceae em número de espécies com aproximadamente 3 mil espécies e cerca de 150 gêneros (NORDENSTAM et al., 2009). A tribo foi tradicionalmente dividida nas subtribos Blennospermatinae, Senecioninae e Tussilagininae (BREMER, 1994). No entanto, análises filogenéticas recentes baseadas em informações moleculares sugerem que a tribo seja dividida em 4 subtribos: Abrotanellinae, Othonninae, Senecioninae e Tussilagininae (NORDENSTAM et al., 2009; PELSER et al. 2007). Dessas subtribos, apenas Senecioninae possui espécies ocorrentes no Brasil.

Apesar da grande riqueza em número de espécies da tribo, a maioria dos táxons pode ser reconhecida primariamente pelas brácteas involucrais, que são de tamanhos iguais entre si e que estão dispostas em uma única série (BREMER, 1994; PELSER et al., 2007). Frequentemente, esse invólucro unisseriado possui uma série externa de brácteas que é conhecida como calículo (BREMER, 1994). Por outro lado, a tribo apresenta uma grande variação morfológica em outras características, como formato e tamanho da lâmina foliar, indumento, capitulescência, tipo de capítulo e coloração das flores (NORDENSTAM et al., 2009).

Além de possuir características morfológicas singulares, as espécies de Senecioneae são caracterizadas por acumularem compostos químicos secundários, como alcaloides pirrolizidínicos e sesquiterpenos do tipo furanoeremofilanos (ROBINS, 1977). Devido à presença desses alcaloides, muitas espécies são altamente hepatotóxicas, particularmente ao gado. 
Senecioneae possui distribuição cosmopolita (BREMER, 1994); no entanto, há importantes centros geográficos de especiação e diversificação de gêneros. No continente africano, a maior diversidade de gêneros é encontrada na África do Sul (25 gêneros), enquanto que no continente americano, as maiores diversidades são encontradas no México (18 gêneros), Peru (17 gêneros) e Colômbia (15 gêneros) (NORDENSTAM et al., 2009). As espécies da tribo ocorrem predominantemente em áreas temperadas e subtropicais áridas ou regiões montanhosas (NORDENSTAM, 2007).

\section{Descrição}

Ervas, arbustos, lianas ou árvores. Folhas alternas, em roseta ou distribuídas ao longo dos ramos, sésseis ou pecioladas, inteiras ou pinatissectas. Capitulescência corimbiforme, paniculiforme ou tirsoide, terminal ou axilar ou capítulo solitário. Capítulos radiados, disciformes ou discoides, heterógamos ou homógamos; invólucro unisseriado, caliculado ou ecaliculado; brácteas involucrais livres ou conatas; receptáculo plano, convexo ou cônico, desprovido de projeções ou fimbriado a denticulado, piloso ou glabro, meduloso ou fistuloso. Flores do raio pistiladas, corola liguliforme ou tubuloso-filiforme, flores do disco bissexuadas, corola tubulosa 5-lobada, corola geralmente amarela, algumas vezes branca, alaranjada, rosada, vermelha ou lilás; estames com anteras apendiculadas apicalmente, base obtusa, sagitada ou caudada; tecido endotecial com células com espessamento radial ou polarizado, raramente transicional; colar da antera reto, uniforme ou basalmente dilatado (balustriforme) com longas células; estilete bífido, apicalmente truncado, obtuso, arredondado ou triangular, algumas vezes longamente acuminado com tricomas fusionados ou com distinto tufo de tricomas; áreas estigmáticas contínuas ou separadas. Cipsela costada, cilíndrica ou obovoide, glabra ou variavelmente pubescente; pápus de poucas a muitas cerdas, persistentes ou caducas, uni a multisseriadas, finas, brancas, estramíneas ou púrpura.

No Brasil, Senecioneae está representada por 8 gêneros e aproximadamente 100 espécies, concentradas especialmente nos campos rupestres e campos de altitude das serras e montanhas das regiões Sudeste e Sul. 
Algumas espécies exóticas são utilizadas como ornamentais, a exemplo de Curio rowleyanus (H. Jacobsen) P.V. Heath, Senecio flaccidus Less., S. viravira Hieron. e Senecio tamoides DC. Outras, como Pseudogynoxys cabrerae H. Rob. \& Cuatrec., Emilia fosbergii Nicolson (Figura 14E) e E. sonchifolia (L.) DC., ocorrem como subespontâneas. Representantes de Senecioneae são encontrados na Figura 14D-I.

\section{Chave de identificação para os gêneros de Senecioneae no Brasil}

1. Capítulos discoides; brácteas involucrais e flores do capítulo em número de 5 Hoehnephytum

1'. Capítulos disciformes, radiados ou discoides; porém, se discoides, com brácteas involucrais e flores do capítulo em número maior que 5 2

2. Capítulos disciformes, flores periféricas com corola longamente filiforme (Figura 9I) Erechtites

2'. Capítulos radiados, flores do raio com corola distintamente liguliforme, e/ou capítulos discoides, com todas as flores com corola tubulosa 3

3. Ramos do estilete com ápice convexo (Figuras 9G,J) ou truncado (Figuras 9K-L)

3'. Ramos do estilete com ápice truncado, com conspícuo tufo de tricomas partindo do centro (Figura 9J), ou apendiculado, longamente acuminado, com tricomas fusionados (Figura 13A) ou apêndice penicilado 7

4. Capítulos discoides Senecio

4'. Capítulos radiados 5

5. Ramos do estilete com ápice convexo (Figura 9G) Dendrophorbium

5'. Ramos do estilete com ápice truncado (Figuras 9K-L) 6

6. Plantas escandentes. Pentacalia

6'. Plantas eretas, prostradas ou decumbentes Senecio 
7. Ramos do estilete com ápice truncado, com conspícuo tufo de tricomas partindo do centro, circundado por coroa de tricomas curtos, divergentes (Figura 9J) Graphistylis

7'. Ramos do estilete com ápice apendiculado, longamente acuminado, com tricomas fusionados (Figura 13A) ou apêndice penicilado, sem coroa de tricomas divergentes 8

8. Subarbustos a arbustos escandentes, perenes; capítulos radiados; invólucro caliculado; ramos do estilete com ápice longamente acuminado, com tricomas fusionados (Figura 13A) Pseudogynoxys 8'. Ervas eretas, anuais; capítulos discoides; invólucro ecaliculado (Figura 9H); ramos do estilete com ápice com apêndice penicilado Emilia

\section{Literatura recomendada}

BAKER, J. G. Compositae IV: Helianthoideae - Mutisiaceae. In: MARTIUS, C. F. P.; EICHLER, A. G., Flora Brasiliensis. Monachii: Lipsiae, 1884. v. 6, pt. 3, p. 135-398.

BELCHER, R. O. A revision of the genus Erechtites (Compositae), with inquiries into Senecio and Arrhenechthites. Annals of the Missouri Botanical Garden, Saint Louis, v. 43, n. 1, p. 1-85, 1956.

BREMER, K. Asteraceae: cladistics and classification. Portland: Timber Press, 1994.

CABRERA, A. L. Notes on the Brazilian Senecioneae. Brittonia, [Bronx], v. 7, n. 2, p. 53-74, 1950.

CABRERA, A. L. El género Senecio (Compositae) en Brasil, Paraguay y Uruguay. Arquivos do Jardim Botânico do Rio de Janeiro, Rio de Janeiro, v. 15, p. 163-264, 1957.

CABRERA, A. L.; KLEIN, R. M. Compostas - Tribo: Senecioneae. In: REITZ, R. Flora ilustrada catarinense. Itajaí: Herbário Barbosa Rodrigues, 1975. p. 126-222. 
JEFFREY, C. Notes on Compositae, VI: The tribe Senecioneae (Compositae) in the Mascarene Islands with an annotated world check-list of the genera of the tribe. Kew Bulletin, London, v. 47, p. 49-109, 1992.

HIND, D. J. N. Pseudogynoxys cabrerae; Compositae. Curtis's Botanical Magazine, [Oxford], v. 9, n. 4, p. 153-200, 1992.

HIND, D. J. N. A checklist of the Brazilian Senecioneae (Compositae). Kew Bulletin London, v. 48, n. 2, p. 279-295, 1993.

HIND, D. J. N. The tribe Senecioneae (Compositae) in Bahia, Brazil, with descriptions of a new section and species in Senecio. Kew Bulletin, London, v. 54 , n. 4 , p. $897-904,1999$.

JEFFREY, C. The tribe Senecioneae (Compositae) in the Mascarene Islands with an annotated world check-list of the genera of the tribe: Notes on Compositae: VI. Kew Bulletin, London, v. 47, n. 1 p. 49-109, 1992.

MATZENBACHER, N. I. O complexo "Senecionóide" (Asteraceae - Senecioneae) no Rio Grande do Sul - Brasil. Porto Alegre: Instituto de Biociências, Universidade Federal do Rio Grande do Sul, Tese de Doutorado. 1998. $274 \mathrm{p}$.

NORDENSTAM, B. Taxonomic studies in the tribe Senecioneae (Compositae). Lund: Lund Botanical Society, 1978. p. 1-83. (Opera Botanica, v. 44)

NORDENSTAM, B. XII. The tribe Senecioneae Cass. 1819. In: KADEREIT, J. W.; JEFFREY, C. (Ed.). The Families and Genera of Vascular Plant: v. VIII:

Flowering Plants Eudicots: Asterales. Berlin; Springer, 2007. p. 208-241.

NORDENSTAM, B. et al. Senecioneae. In: FUNK, V. A. et al. (Ed.). Systematics, evolution and biogeography of Compositae. Vienna: IAPT, 2009. p. 503-525.

PELSER, P. B. et al. An ITS phylogeny of tribe Senecioneae (Asteraceae) and a new delimitation of Senecio L. Taxon, Utrecht v. 56, n. 4, p. 1077-1104, 2007. 
PRUSKI, J. F. Pseudogynoxys lobata (Compositae: Senecioneae), a new species from Bolivia and Brazil. Systematic Botany, Kent, v. 21, n. 1, p. 101-105, 1996.

ROBINS, D. J. Senecioneae - chemical review. In: HEYWOOD, V. H.;

HARBORNE, J. B.; TURNER, B. L. The biology and chemistry of the Compositae. London: Academic Press, 1977. p. 831-850.

ROBINSON, H.; CUATRECASAS, J. Notes on the genus and species limits of Pseudogynoxys (Greenm.) Cabrera (Senecioneae, Asteraceae). Phytologia,Huntsville, v. 36, p. 177-192, 1977.

ROBINSON, H.; CUATRECASAS, J. A review of the Central American species of Pentacalia (Asteraceae: Senecioneae). Phytologia, Huntsville, v. 40, p. $37-50,1978$.

TELES, A. M. Nova combinação e chave revisada para Dendrophorbium (Asteraceae - Senecioneae) no Brasil. Rodriguésia, Rio de Janeiro, v. 61, n. 1, p. 143-145, 2010.

TELES, A. M.; FREITAS, F. S. Senecio hortensiae (Asteraceae, Senecioneae): a new species from Espírito Santo, Brazil. Phytotaxa, Auckland, v. 142, n. 1, p. 46-50, 2013.

TELES, A. M.; NAKAJIMA, J. N.; STEHMANN, J. R. Senecio albus, a new species of Senecio sect. Adamantina (Senecioneae - Asteraceae) with an emendment to the section. Kew Bulletin, London, v. 64, n. 1, p. 161-165, 2009.

TELES, A. M.; STEHMANN, J.R. 2011. Flora da Serra do Cipó, Minas Gerais: Asteraceae - Senecioneae. Boletim de Botânica da Universidade de São Paulo, São Paulo, v. 29, n. 1, p. 57-68, 2011.

TELES, A. M.; STEHMANN, J. R. 2016. A tribo Senecioneae (Asteraceae) em Minas Gerais, Brasil. Rodriguésia, Rio de Janeiro, v. 67, n. 2, p. 455-487, 2016. 


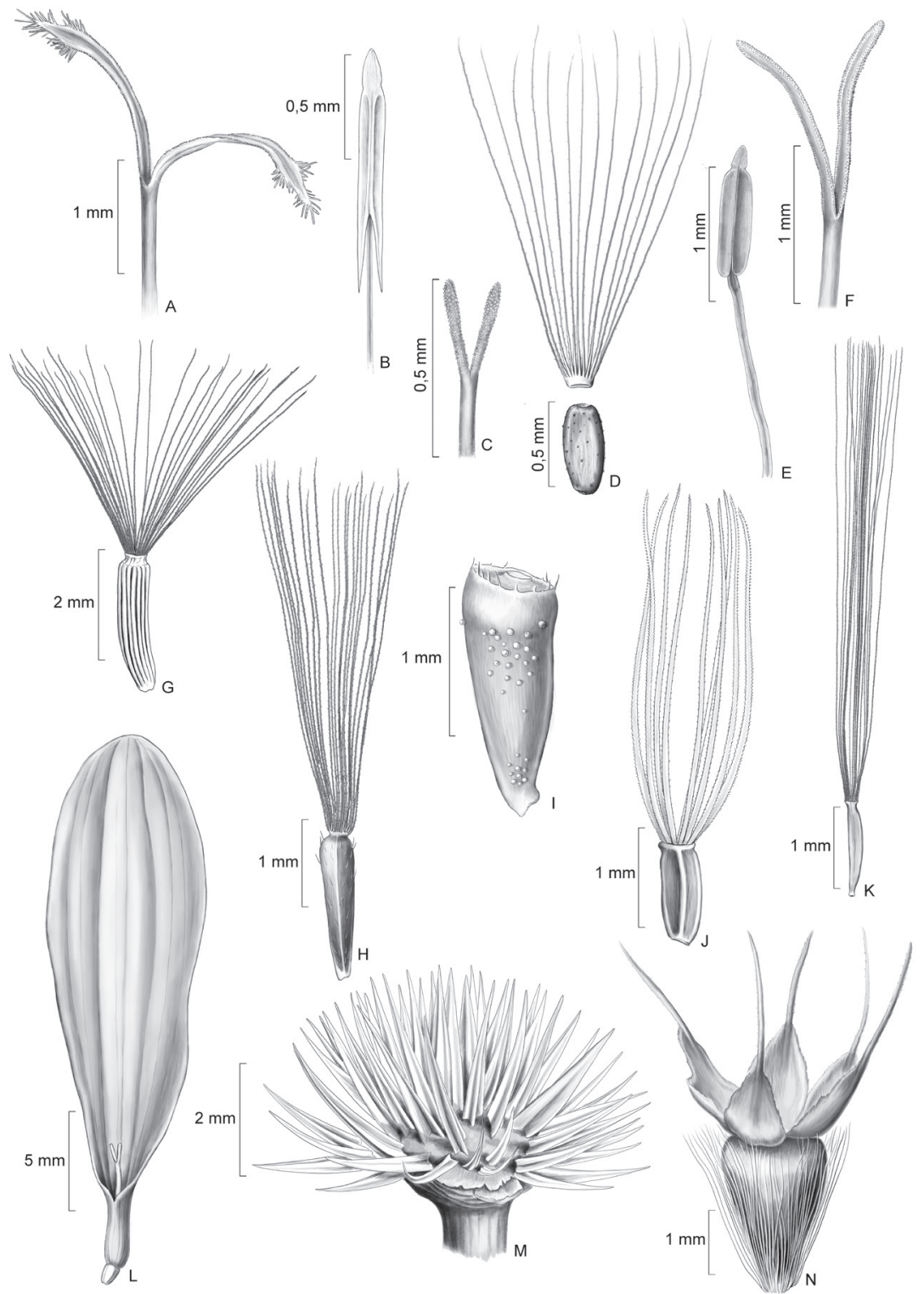

Figura 13. Senecioneae. A. Estilete de Pseudogynoxys cabrerae H.Rob. \& Cuatrec. Gnaphalieae. B-C. Chionolaena jeffreyi H. Rob.: B. Antera; C. Ramos do estilete. D. Cipsela e pápus de Gamochaeta pensylvanica (Willd.) Cabrera. Astereae. E-G. Baccharis aleluia A.S. Oliveira \& Deble: E. Antera ecaudada; F. Ramos do estilete; G. Cipsela e pápus; H. Cipsela e pápus de Conyza primulifolia (Lam.) Cuatrec. \& Lourteig; I. Cipsela e pápus de Egletes viscosa (L.) Less.; J. Cipsela e pápus de Grindelia brachystephana Griseb.; K. Cipsela e pápus de Podocoma notobellidiastrum (Griseb.) G.L. Nesom. Anthemideae. L. Flor ligulada feminina de Chrysanthemum sp. Helenieae. M-N. Gaillardia pulchella Foug.: M. Receptáculo paleáceo; N. Cipsela e pápus. 

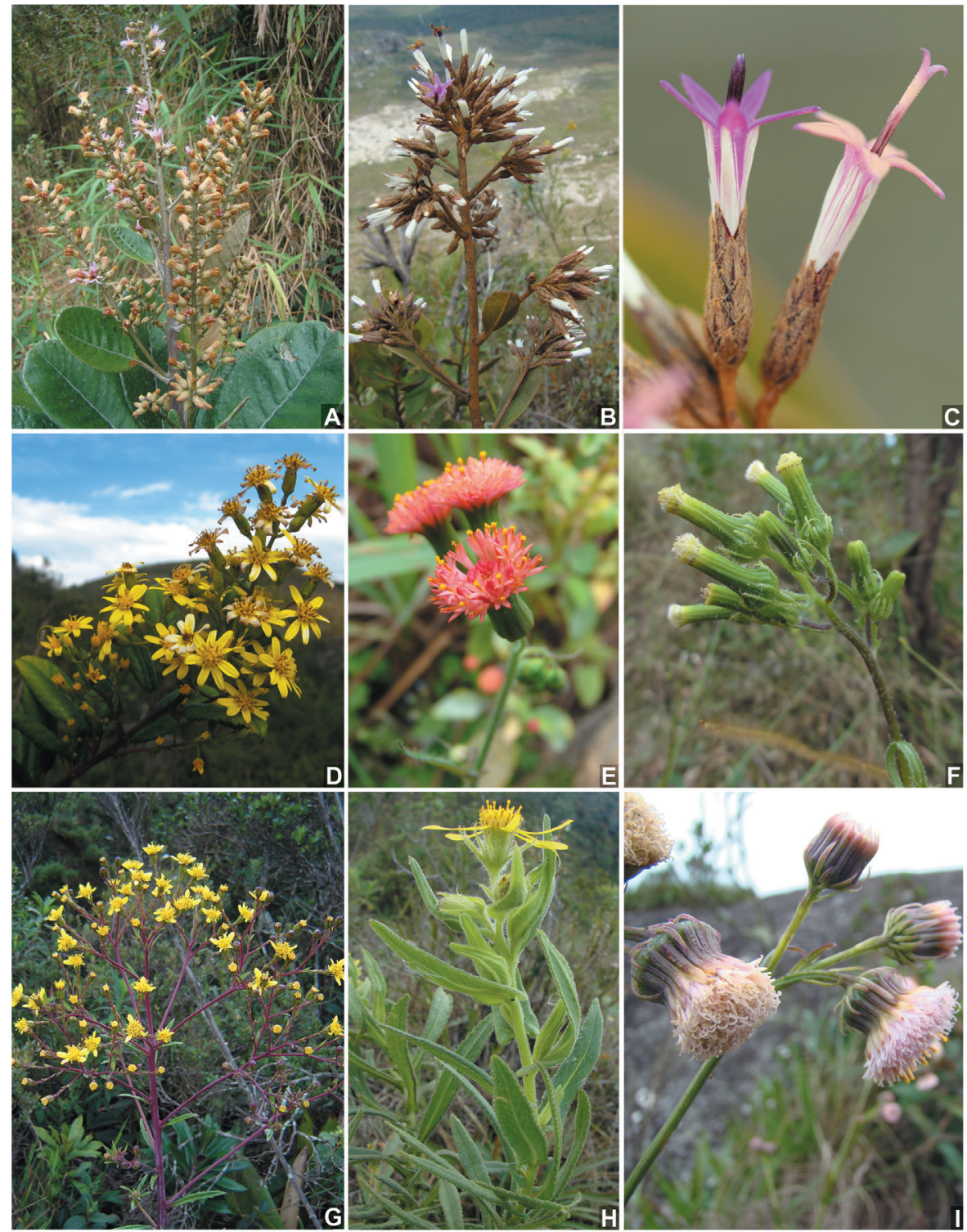

Figura 14. Moquinieae. A. Moquinia racemosa (Spreng.) DC.; B-C. Pseudostifftia kingii H. Rob. Senecioneae. D. Dendrophorbium pellucidinerve (Sch.Bip. ex Baker) C.Jeffrey; E. Emilia fosbergii Nicolson; F. Erechtites hieracifolius (L.) Raf. ex DC.; G. Graphistylis dichroa (Bong.) D.J.N. Hind; H. Senecio oleosus Vell.; I. Senecio pohlii Sch. Bip. ex Baker. 


\section{TRIBO GNAPHALIEAE (CASS.) LECOQ. \& JUILL.}

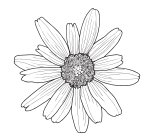

Leonardo Paz Deble

A tribo Gnaphalieae é composta de 180-190 gêneros e cerca de 1.240 espécies, com distribuição quase cosmopolita, com maior diversidade na África do Sul, Ásia, Austrália e América do Sul (BAYER et al., 2007; DILLON; SAGASTEGUI, 1991; WARD et al., 2009). Para a América do Sul, Dillon e Sagastegui (1991) reconheceram 2 centros de diversidade: a Cordilheira dos Andes e o Sudeste do Brasil e regiões adjacentes.

Tradicionalmente, Gnaphalieae foi subordinada à tribo Inuleae, sendo reconhecida como um dos grupos de mais difícil identificação dentro da família, dadas a homogeneidade dos caracteres vegetativos e a escassa variação dos caracteres florais (CABRERA, 1961). Estudos recentes demonstraram que as Gnaphalieae encerram grupo monofilético posicionado na base da subfamília Asteroideae (ANDERBERG, 2009; ANDERBERG et al., 2005; FUNK et al., 2005).

A delimitação genérica dentro da tribo Gnaphalieae tem sido discutida em diversos estudos (ANDERBERG, 1991; DILLON; SAGASTEGUI, 1991; MERXMÜLLER; LEINS; ROESSLER, 1977). No tocante aos gêneros representados no Brasil, Chionolaena DC., Achyrocline (Less.) DC. e Pseudognaphalium Kirp. são os que apresentam maior complexidade taxonômica. Os gêneros Gnaphaliothamnus Kirp., Leucopholis Gardner, Parachionolaena M.O. Dillon \& Sagást e Pseudoligandra M.O. Dillon \& Sagást. foram subordinados a Chionolaena (ANDERBERG, 1991; FREIRE, 1993). Stenophalium A. Anderb. foi transferido para Achyrocline (PAZ-DEBLE; MARCHIORI, 2005). Gamochaeta Wedd., no entanto, tem sido reconhecido como separado de Gnaphalium sensu stricto (ANDERBERG, 1991; DILLON; SAGASTEGUI 1991; FREIRE; 
IHARLEGUI, 1997; PAZ-DEBLE; MARCHIORI, 2007; CHEN; ZHU; BAYER, 2011; URTUBEY et al., 2016), enquanto Pseudognaphalium figura como segregado dos gêneros Achyrocline e Helichrysum Mill (ANDERBERG, 1991; BAYER et al., 2007; HILLIARD; BURTT, 1981; WARD et al., 2009).

Para a identificação de gêneros e espécies, sugere-se a utilização dos trabalhos clássicos de Ángel Cabrera (1963, 1971, 1974, 1978) para a flora da Argentina e obras mais recentes, que também abordam a identificação de gêneros e espécies, como por exemplo: Freire (1993, 1995, 1998, 2014), Freire, Paz-Deble, Iharlegui (2011), Loeuille, Paz-Deble e Nakajima (2011), Paz-Deble e Marchiori, (2006, 2007) e Schneider, Trevisan e Boldrini (2011).

\section{Descrição}

Ervas anuais ou perenes, raramente subarbustos, monoicos ou mais raramente dioicos, frequentemente lanosos. Folhas simples, alternas, opostas ou rosuladas, lâmina foliar de margem inteira, frequentemente lanosa. Capitulescência em glomérulos ou pseudoespigas, mais raramente capítulos solitários (Chevreulia). Capítulos discoides, homógamos ou disciformes, heterógamos; invólucro estreitamente cilíndrico, campanulado ou hemisférico, brácteas involucrais em 3-8 séries, imbricadas, papiráceas, hialinas ou opacas, frequentemente escabrosas, providas de região basal mais engrossada (estereoma), as externas menores que as internas, raro de igual tamanho; receptáculo plano ou côncavo, faveolado, liso ou com fimbrias, raramente paleáceo (Micropsis). Flores 3-500, tubo da corola glabro ou com escassos tricomas bisseriados, glandulares, ápice frequentemente com tricomas glandulares com vesícula terminal; flores marginais pistiladas, corola tubuloso-filiforme, (3)4-5-denteada no ápice; flores do disco estaminadas ou bissexuais, corola tubulosa, 5-denteada no ápice; anteras sagitadas na base; estilete com ápice brevemente 2-partido até bífido. Cipselas cilíndricas ou angulosas, raro comprimidas, com células da epideme imbricadas ou não, seríceo pubescente, pela presença de tricomas geminados longos (Lucilia, Chionolaena), glabras (Achyrocline) ou granulosas pela ocorrência de tricomas geminados semiesféricos ou arredondados (Gamochaeta); pápus 1-3-seriado, raramente ausente (Micropsis), com cerdas plumosas (Berroa, Facelis) ou esca- 
brosas, unidas em anel na base (Lucilia, Gamochaeta) ou livres (Gnaphalium), de células apicais agudas (Lucilia) até clavadas (Chionolaena) e células basais ascendentes ou patentes.

No Brasil, Gnaphalieae encontra-se representada por 12 gêneros e 79 espécies nativas, principalmente no Sul do país e em campos de altitude e campos rupestres do Sudeste e Nordeste. No Sul do país, há o registro de Helichrysum foetidum (L.) Moench e Xerochrysum bracteatum (Vent.) Tzvelev como subespontâneas. (Barcelos \& Heiden, 2017) As espécies de Micropsis (3 spp.) e Berroa gnaphalioides (Less.) Beauverd são representadas apenas em áreas campestres do Rio Grande do Sul. Chevreulia (3 spp.) e Lucilia (6 spp.) se distribuem no Sul, Sudeste e Centro-Oeste do país, enquanto Pseudognaphalium (5 spp.) e Facelis retusa (Lam.) Beauverd ocorrem em áreas abertas do Sul, Sudeste e Nordeste. Achyrocline (25 spp.) e Gamochaeta (20 spp.), por sua vez, estão representados em quase todo Brasil. Chionolaena (12 spp.) (Figuras 13B-C) ocorre principalmente em campos de altitude do Sudeste, enquanto Gnaphalium polycaulon Pers., única espécie cosmopolita do gênero representada no Brasil, ocorre em território nacional no Sudeste, Centro-Oeste e Nordeste (Bahia).

\section{Chave de identificação para os gêneros de Gnaphalieae no Brasil}

1. Receptáculo paleáceo; flores com pápus ausente ou reduzido a escamas ou cerdas curtas Micropsis

1'. Receptáculo desprovido de páleas; flores com pápus desenvolvido ...... 2

2. Pápus formado por cerdas plumosas ……………………………………..... 3

2'. Pápus formado por cerdas escabrosas ……………………………………... 4

3. Cipsela provida de tricomas curtos e 6-12 tricomas distais, quase tão longos quanto o pápus .............................................................................. Berroa

3'. Cipsela com tricomas curtos em toda a extensão .............................. Facelis

4. Cipsela seríceo-pubescente, provida de tricomas geminados alongados ... 5

4'. Cipsela glabra ou com tricomas espalhados 6 
5. Ervas perenes; flores do disco bissexuais; pápus formado por cerdas delgadas, com células apicais obtusas a levemente agudas Lucilia 5'. Subarbustos; flores do disco estaminadas; pápus formado por cerdas mais ou menos espessas, com células apicais clavadas ou rotundas.

Chionolaena

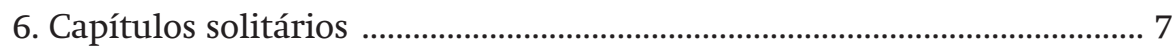

6'. Capítulos reunidos em capitulescências ..................................................... 8

7. Plantas delicadas, prostradas ou em roseta; capítulos inicialmente sésseis e sustentados por longo pedúnculo na maturidade; brácteas involucrais translúcidas, cipsela fortemente comprimida a rostrada na porção distal ... Chevreulia

7'. Plantas robustas, eretas ou ascendentes; capítulos pedunculados, com brácteas involucrais rígidas, opacas; cipsela oblonga, desprovida de rostro.

Xerochrysum

8. Cerdas do pápus soldadas na base, desprendendo-se em conjunto (Figura 13D)

Gamochaeta

8'. Cerdas do pápus livres, desprendendo-se isoladas ou em grupos de 2-4 cerdas.

9. Capítulos com 3-20 flores Achyrocline

9'. Capítulos com mais de 20 flores 10

10. Plantas prostradas, com menos de $20 \mathrm{~cm}$ de altura; capítulos dispostos em glomérulos formando pseudoespigas terminais Gnaphalium 10. Plantas eretas ou ascendentes, com mais de $20 \mathrm{~cm}$ de altura; capítulos dispostos em corimbos, glomérulos corimbiformes ou paniculiformes........

11. Flores femininas em maior número que as do disco

Pseudognaphalium

11'. Flores femininas em menor número que as do disco Helichrysum 


\section{Literatura recomendada}

ANDERBERG, A. A. Inuleae. In: V.A. FUNK; A. et al. Systemtics, Evolution, and Biogeography o Compositae. Vienna: IAPT, 2009. p. 667-680.

ANDERBERG, A. A. Taxonomy and phylogeny of the tribe Gnaphalieae (Asteraceae). Opera Botanica, Lund, v. 104, p. 1-195, 1991.

ANDERBERG, A. A. et al. Evolutionary relationships in the Asteraceae tribe Inuleae (Incl. Plucheae) evidenced by DNA sequences of ndhF, with notes on the systematic position of some aberrant genera. Organism, Diversity and Evolution, Jena, v. 5, n. 2, p. 135-146, 2005.

BARCELOS, L.; HEIDEN, G. First record of Helichrysum foetidum (L.) Moench. (Asteraceae, Gnaphalieae) for South America. Check List, [S.1.], v. 13, n. 4, p. 331-334, 2017.

BAYER, R. J. et al. Tribe Gnaphalieae. In: KADEREIT, J. W.; JEFFREY, C. (Ed.). KADEREIT, J. W.; JEFFREY, C. (Ed.). The Families and Genera of Vascular Plant: v. VIII: Flowering Plants Eudicots: Asterales. Berlin: Springer, 2007. p. 246-283.

CABRERA, Á. L. Compositae. In: CABRERA, Á. L. Flora de la Provincia de Buenos Aires (Argentina). Buenos Aires: INTA, 1963. t. IV, par. VI.

CABRERA, Á. L. Compositae. In: CORREA, M. N. Flora Patagonica (Argentina). Buenos Aires: INTA, 1971. t. VIII, par. VII.

CABRERA, Á. L. Compositae. In: BURKART, A. Flora Ilustrada de Entre Rios (Argentina). Buenos Aires: INTA, 1974. tomo VI, par. VI, p. 106-554.

CABRERA, Á. L. Compositae. In: CABRERA, Á. L. Flora de la Provincia de Jujuy (Argentina). Buenos Aires: INTA, 1978. t. VIII, parte X.

CABRERA, Á. L. Observaciones sobre las Inuleae-Gnaphalieae (Compositae) de América del Sur. Boletín de la Sociedad Argentina Botánica, Córdoba, v. 9, p. 359-386, 1961.

CHEN, Y. S.; ZHU, S. X.; BAYER, R. H. Gnaphalieae. In: WU, Z. Y.; RAVEN, P. H.; HONG, D. Y. Flora of China. Beijing: Science Press; St. Louis: Missouri Botanical Garden Press, 2011. v. 20-21, p. 774-818. 
DILLON, M.O.; SAGASTEGUI, A. Sinopsis de los géneros de Gnaphaliinae (Asteraceae-Inuleae) de Sudamérica. Arnaldoa, Trujillo, v. 1, n. 2, p. 5-91, 1991.

FREIRE, S. E. Asteraceae: Anthemidae a Gnaphalieae. Gnaphalieae. In: ZULOAGA, F.O.; BELGRANO, M. J.; ANTON, A. M. Flora Argentina: flora vascular da República Argentina. Dicotyledoneae, Asteraceae. [Buenos Aires: Instituto de Botánica Darwinion], 2014. t. I, v. 7, p. 438-512.

FREIRE, S. E. Asteraceae. Tribu IV. Inuleae. In: HUNZIKER, A.T. (Ed.). Flora Fanerogámica Argentina. Córdoba: CONICET, 1995. v. 14. p. 1-60.

FREIRE, S. E. A revision of Chionolaena (Compositae, Gnaphalieae). Annals of Missouri Botanical Garden, [New York], v. 80, n. 2, p. 397-438, 1993.

FREIRE, S. E. Tribu Inuleae. Compositae. In: SPICHIGER, R.; RAMELLA, L. Flora del Paraguay. [Genève: Ed. des Conservatoire et Jardin botaniques de la Ville de Genève], 1998. v. 27, p. 9-100.

FREIRE, S. E.; IHARLEGUI, L. Sinopsis preliminar del género Gamochaeta (Asteraceae: Gnaphalieae). Boletín de la Sociedad Argentina Botánica, Córdoba, v. 33, p. 23-35, 1997.

FREIRE, S. E.; PAZ-DEBLE, L.; IHARLEGUI, L. Compostas. V. Tribo Inuleae. In REITZ, R. (Ed.). Flora Ilustrada Catarinense: Herbário “Barbosa Rodrigues”. Santa Catarina: Itajaí, 2011. p. 1067-1197.

FUNK, V. A. et al. Everywhere but Antarctica: using a supertree to understand the diversity and distribution of the Compositae. Biologiske Skrifter, Copenhagen, n. 55, p. 343-374, 2005.

HILLIARD, O. M.; BURTT, B. L. Some generic concepts in CompositaeGnaphaliinae. Botanical Journal of the Linnean Society, London, v. 82, n. 2, p. 181-231, 1981.

LOEUILLE, B.; PAZ-DEBLE, L.; NAKAJIMA, J. N. Four new species of Chionolaena (Asteraceae: Gnaphalieae) from south-eastern Brazil. Kew Bulletin, London, v. 66, n. 3, p. 263-272, 2011. 
MERXMÜLLER, H.; LEINS, P.; ROESSLER, H. Inuleae-systematic review. In: HEYWOOD, V. H.; HARBORNE, J. B.; TURNER, B. L. The Biology and chemistry of the compositae. London: Academy press, 1977. p. 577-612.

PAZ-DEBLE, L.; MARCHIORI, J. N. C. Redução de Stenophalium A. Anderb. A sinonímia de Achyrocline (Less.) DC. (Asteraceae: Gnaphalieae). Balduinia, Santa Maria, v. 4, p. 10-19, 2005.

PAZ-DEBLE, L.; MARCHIORI, J. N. C. Sinopse do gênero Pseudognaphalium Kirp. (Asteraceae-Gnaphalieae) no Brasil. Balduinia, Santa Maria, v. 9, p. 13-16, 2006.

PAZ-DEBLE, L.; MARCHIORI, J. N. C. Sinopse do gênero Gamochaeta Weddel (Asteraceae-Gnaphalieae) no Brasil. Balduinia, Santa Maria, v. 10, p. 21312007.

PAZ-DEBLE, L.; OLIVEIRA-DEBLE, A. S. de. Novelties to Compositae Family in Rio Grande do Sul State Flora. Balduinia, Santa Maria, v. 29, p. 1-8, 2011. SCHNEIDER, A. A.; TREVISAN, R.; BOLDRINI, I. I. New species of Chevreulia (Asteraceae: Gnaphalieae) from Brazil. Systematic Botany, v. 36, n. 3, p. 782-784, 2011.

URTUBEY, E. et al. New Circumscription of the genus Gamochaeta (Asteraceae: Gnaphalieae) inferred from nuclear and plastid DNA sequences. Plant Systematic and Evolution, New York, 302, n. 8, p. 1047-1066, 2016.

WARD, J. et al. Gnaphalieae. In: FUNK, V. A et al. Systematics, evolution, and biogeography of Compositae. Vienna: IAPT, 2009. p. 539-588. 


\title{
TRIBO ASTEREAE CASS.
}

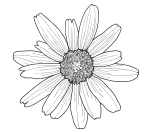 \\ Aristônio M. Teles \\ Gustavo Heiden \\ Angelo A. Schneider
}

Astereae emergiu como um grupo monofilético em inúmeros estudos filogenéticos (BROUILLET et al., 2009; PANERO; FUNK, 2008). A tribo compreende 18 subtribos, 222 gêneros, cerca de 3.100 espécies e apresenta distribuição cosmopolita (BROUILLET et al., 2009; NESOM; ROBINSON, 2007). Na América do Sul, ocorrem 31 gêneros e cerca de 740 espécies (NESOM, 1994e). Os representantes da tribo são geralmente caracterizados pelas anteras ecaudadas e ecalcaradas (Figura 13E), ramos do estilete das flores estaminadas ou bissexuadas triangulares ou lanceolados e com tricomas coletores abaxialmente (Figura 13F) (BROUILLET et al., 2009).

\section{Descrição}

Ervas a arbustos, ocasionalmente pequenas árvores ou trepadeiras, monoicas ou dioicas. Folhas alternas ou rosuladas, raro opostas. Capitulescência corimbiforme, paniculiforme ou capítulos solitários. Capítulos disciformes, discoides ou radiados; receptáculo geralmente epaleáceo, raramente paleáceo nos capítulos pistilados. Flores do raio 1-multisseriadas, pistiladas, corola liguliforme ou tubuloso-filiforme, amarela, branca, lilás ou rósea; flores do disco bissexuadas ou estaminadas, corola tubulosa, amarela ou esbranquiçada; anteras com base obtusa, truncada ou levemente auriculada, apêndice do conectivo curto, ovalado 
ou lanceolado; estilete das flores bissexuadas ou estaminadas com ramos triangulares ou lanceolados, apêndices apicais estéreis, linhas estigmáticas laterais, tricomas coletores distribuídos na face abaxial dos ramos do estilete. Cipselas com ápice truncado, atenuado ou rostrado, 2-multicostadas, epiderme uniestratificada com células espessadas em 3 dos seus lados (espessamento de parede em forma de “U”), glabras ou pilosas; pápus 1-3-seriado, cerdoso, escamiforme ou ausente, persistente ou caduco.

No Brasil, Astereae está representada por 9 subtribos, 18 gêneros e 247 espécies, das quais 137 são endêmicas, sendo que a maior diversidade é encontrada nas regiões Sudeste e Sul. Dentre os gêneros mais representativos na flora do Brasil, podemos citar: Baccharis L. (incluindo Baccharidastrum Cabrera, Baccharidiopsis G.M. Barroso e Heterothalamus Less., como sinônimos conforme Heiden \& Pirani, 2016), representado por 179 espécies, das quais 115 são endêmicas e cuja distribuição é majoritariamente extra-amazônica; Conyza L., com 15 espécies, a maioria ruderais; e Noticastrum DC., com 8 espécies, distribuídas principalmente em campos, restingas e vegetação secundária no Sul e Sudeste. Algumas espécies como Conyza bonariensis (L.) Cronquist, C. primulifolia (Lam.) Cuatr. \& Lourteig, C. sumatrensis (Retz.) E. Walker, Egletes viscosa Less., Solidago chilensis Meyen e Symphyotrichum squamatum (Spreng.) G.L. Nesom são de ampla valência ecológica e frequentemente encontradas como ruderais. Representantes de Astereae são encontrados na figura 15.

\section{Chave de identificação para os gêneros de Astereae no Brasil}

1. Capítulos disciformes ou discoides ................................................................. 2

1'. Capítulos radiados a inconspicuamente radiados........................................ 7

2. Capítulos disciformes ...................................................................................... 3

2'. Capítulos discoides ................................................................................ 6

3. Folhas paralelinérveas; flores pistiladas 1-seriadas; cipselas cilíndricas, 5-costadas ........................................................................................... Apopyros

3'. Folhas peninérveas ou reticulinérveas; flores pistiladas multisseriadas; cipselas comprimidas, 2-costadas ...................................................................... 4 
4. Brácteas involucrais 3-nervadas; cipselas com ápice truncado; pápus 1-seriado (Figura 13H) Conyza

4'. Brácteas involucrais 1-nervadas; cipselas rostradas ou apenas atenuadas no ápice; pápus 1-3-seriado 5

5. Cipselas apenas atenuadas no ápice; pápus 1(2-3)-seriado ......... Exostigma 5’. Cipselas rostradas; pápus 2(3)-seriado (Figura 13K) Podocoma

6. Brácteas involucrais 3-seriadas; capítulos com flores funcionalmente estaminadas; capítulos com flores pistiladas ou ainda capítulos com flores bissexuadas; cipselas fusiformes (Figura 13G).................................. Baccharis 6'. Brácteas involucrais 4-seriadas; capítulos com flores sempre bissexuadas; cipselas ovoides, comprimidas ou prismáticas (Figura 13J) Grindelia

7. Flores do raio neutras Baccharis

7’. Flores do raio pistiladas 8

8. Flores do disco funcionalmente estaminadas ................................................. 9

8'. Flores do disco bissexuadas .................................................................. 13

9. Cipselas cilíndricas a fusiformes, 4-10-costadas ......................... Baccharis

9'. Cipselas comprimidas, 2-costadas ........................................................... 10

10. Folhas pinatilobas ou pinatissectas ………………................................. 11

10'. Folhas inteiras ou denteadas .............................................................. 12

11. Lobos linear-espiniformes ......................................................... Sommerfeltia

11'. Lobos oblongos ou obovados ................................................ Plagiocheilus

12. Flores do raio 1(2)-seriadas; cipselas oblanceoloides a elípticooblanceoloides; pápus 2-3-seriado, esbranquiçado............................. Inulopsis 12'. Flores do raio 3-4-seriadas; cipselas obcônicas; pápus 1-seriado, amareloavermelhado. Asteropsis

13. Cipselas sem pápus (Figura 13I) ....................................................... Egletes

13'. Cipselas com pápus ................................................................................... 14

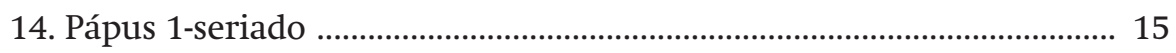

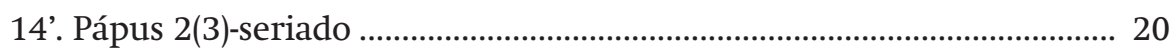


15. Pápus formado por 3-18 cerdas (Figura 13J) ou aristas rígidas e caducas Grindelia

15’. Pápus formado por mais de 20 cerdas capilares e persistentes 16

16. Flores do raio curtamente liguliformes, ou seja, com o limbo da corola mais curto que o estilete e nunca ultrapassando o comprimento das flores do disco Conyza 16'. Flores do raio longamente liguliformes, ou seja, com o limbo da corola mais longo que o estilete e sempre ultrapassando o comprimento das flores do disco.

17. Capitulescências corimbiformes; receptáculo fimbriado; cipselas elipsoides, comprimidas, 2-costadas Leptostelma 17'. Capítulos solitários ou dispostos em capitulescências paniculiformes; receptáculo alveolado; cipselas oblongo-obovoides a obcônicas, não comprimidas, 5-12-costadas 18

18. Plantas escaposas; lâmina foliar filiforme a linear-oblanceolada; capítulos solitários Neja 18'. Plantas folhosas até a capitulescência; lâmina foliar lanceolada a oblanceolada; capitulescências paniculiformes 19

19. Ramos secundários da capitulescência patentes e escorpioides; flores do raio amarelas; cipselas oblongo-obovoides, 5-costadas Solidago 19'. Ramos secundários da capitulescência ramificados; flores do raio brancas ou lilás; cipselas obcônicas, 10-12-costadas Symphyotrichum

20. Folhas com margem profundamente 3-lobadas apicalmente; pápus rubro Microgyne 20’. Folhas com margem íntegra, serreada ou denteada; pápus esbranquiçado

21. Cipselas cilíndricas, 16-26-costadas Noticastrum

21'. Cipselas comprimidas, 2-costadas 22 
22. Plantas geralmente escaposas com folhas basais normalmente dispostas em roseta; cipselas rostradas; pápus com cerdas de tamanhos iguais entre si (Figura 13K) Podocoma

22'. Plantas folhosas até a capitulescência; cipselas com ápice truncado; pápus com série externa curta com cerdas escamiformes e série interna mais longa com cerdas capilares.

Hysterionica

\section{Literatura recomendada}

BARROSO, G. M. Compositae - subtribo Baccharidinae Hoffmann: estudo das espécies ocorrentes no Brasil. Rodriguésia, Rio de Janeiro, v. 28, n. 40, p. 3-273, 1976.

BARTOLI, A.; TORTOSA, R. D. Revisión de las espécies sudamericanas de Grindelia (Asteraceae: Astereae). Kurtziana, v. 27, n. 3, p. 327-359, 1999. BRAZIL FLORA GROUP- BFG. Growing knowledge: an overview of seed Plant diversity in Brazil. Rodriguésia, Rio de Janeiro, v. 66, n. 4, p. 10851113, 2015.

BONIFACINO, J. M.; SANCHO, G.; MARCHESI, E. A new combination in Asteropsis (Compositae: Astereae), and a synopsis of the genus. Brittonia, Bronx, v. 61, n. 1, p. 1-7, 2009.

BROUILLET, L. et al. Astereae. In: FUNK, V. A et al. Systematics, evolution, and biogeography of Compositae. Vienna: IAPT, 2009. p. 587-629.

CABRERA, A. L. El género Hysterionica en el Uruguay y en la República Argentina. Notas del Museo de La Plata, La Plata, v. 11, n. 53, p. 349-359, 1946.

ESPINAR, L. A. Las espécies centroargentinas de Hysterionica (Compositae). Darwiniana, Buenos Aires, v. 22, n. 4, p. 537-549. 1980.

HEIDEN, G.; BAUMGRATZ, J. F. A.; ESTEVES, R. L. Baccharis subgen. Molina (Asteraceae) no estado do Rio de Janeiro, Brasil. Rodriguésia, Rio de Janeiro, v. 63, n. 3, p. 649-687, 2012. 
HEIDEN, G., IGANCI, J. R. V.; MACIAS, L. F. N. Baccharis sect. Caulopterae (Asteraceae, Astereae) no Rio Grande do Sul, Brasil. Rodriguésia, Rio de Janeiro, v. 60, n. 4, p. 943-983, 2009.

HEIDEN, G.; PIRANI, J. R. Novelties towards a phylogenetic infrageneric classification of Baccharis (Asteraceae, Astereae). Phytotaxa, Auckland, v. 289, n. 8, p. 285-290, 2016.

HEIDEN, G.; PIRANI, J. R. Taxonomy of Baccharis subgen. Tarchonanthoides (Asteraceae: Astereae: Baccharidinae), a group from the southeastern South American grasslands and savannas. Phytotaxa, Auckland, v. 241, n. 1, p. 1-70, 2016.

MULLER, J. Systematics of Baccharis (Compositae - Astereae) in Bolivia, including an overview of the genus. Systematics Botany Monographs, [S.1.], v. 76, p. 1-339, 2006.

NESOM, G. L. Apopyros (Asteraceae: Astereae), a new genus from southern Brazil, Argentina, and Paraguay. Phytologia, Huntsville, v. 76, p. 176-184, $1994 a$.

NESOM, G. L. Comments on Microgynella, Sommerfeltia, and Asteropsis (Asteraceae: Astereae). Phytologia, Huntsville, v. 76, p. 101-105, 1994b.

NESOM, G. L. Inulopsis synopsis (Asteraceae: Astereae). Phytologia, Huntsville, v. 76, p. 115-124, 1994c.

NESOM, G. L. Separation of Neja (Asteraceae: Astereae) from Hysterionica. Phytologia, Huntsville, v. 76, p. 168-175, 1994 d.

NESOM, G. L. Subtribal classification of the Astereae (Asteraceae). Phytologia, Huntsville, v. 76, p. 193-274, 1994e.

NESOM, G .L.; ROBINSON, H. Tribe Astereae Cass. In: KADEREIT, J. W.; JEFFREY, C. (Ed.). The Families and Genera of Vascular Plant: v. VIII: Flowering Plants Eudicots: Asterales. Berlin: Springer, 2007. p. 284-342.

PANERO, J. L.; FUNK, V. A. The value of sampling anomalous taxa in phylogenetic studies: major clades of the Compositae revealed. Molecular Phylogenetics and Evolution, Orlando, v. 47, n. 2, p. 757-782, 2008. 
SANCHO, G. Exostigma, a new genus of Astereae (Compositae) from Southern South America. Systematic Botany, Kent, v. 37, n. 2, p. 516-524, 2012.

SANCHO, G.; BONIFACINO, J. M.; Pruski, J. F. Revision of Microgyne (Asteraceae: Astereae), the correct name for Microgynella. Systematic Botany, Kent, v. 31, n. 4, p. 851-861, 2006.

SANCHO, G.; HIND, D. J. N.; PRUSKI, J. F. Systematics of Podocoma (Asteraceae: Astereae): a generic reassessment. Botanical Journal of Linnean Society, London, v. 163, n. 4, p. 486-513, 2010.

SCHNEIDER, A. A.; MODELSKI, V.; BOLDRINI, I. I. Hysterionica (Asteraceae: Astereae) para o Brasil. Rodriguésia, Rio de Janeiro, v. 64, n. 3, p. 597-606, 2013.

SOLBRIG, O. T. The South American species of Erigeron. Contributions from the Gray Herbarium of Harvard University, Cambridge, v. 191, p. 3-82, 1962. TELES, A. M.; SOBRAL, M.; STEHMANN, J. R. Synopsis of Leptostelma (Asteraceae: Astereae). Compositae Newsletter, Stockholm, v. 46, p. 1-6, 2008. ZARDINI, E. M. Revisión del género Noticastrum (Compositae-Astereae). Revista del Museo de La Plata, La Plata, v. 13, p. 313-424, 1985. Seccion Botanica. 


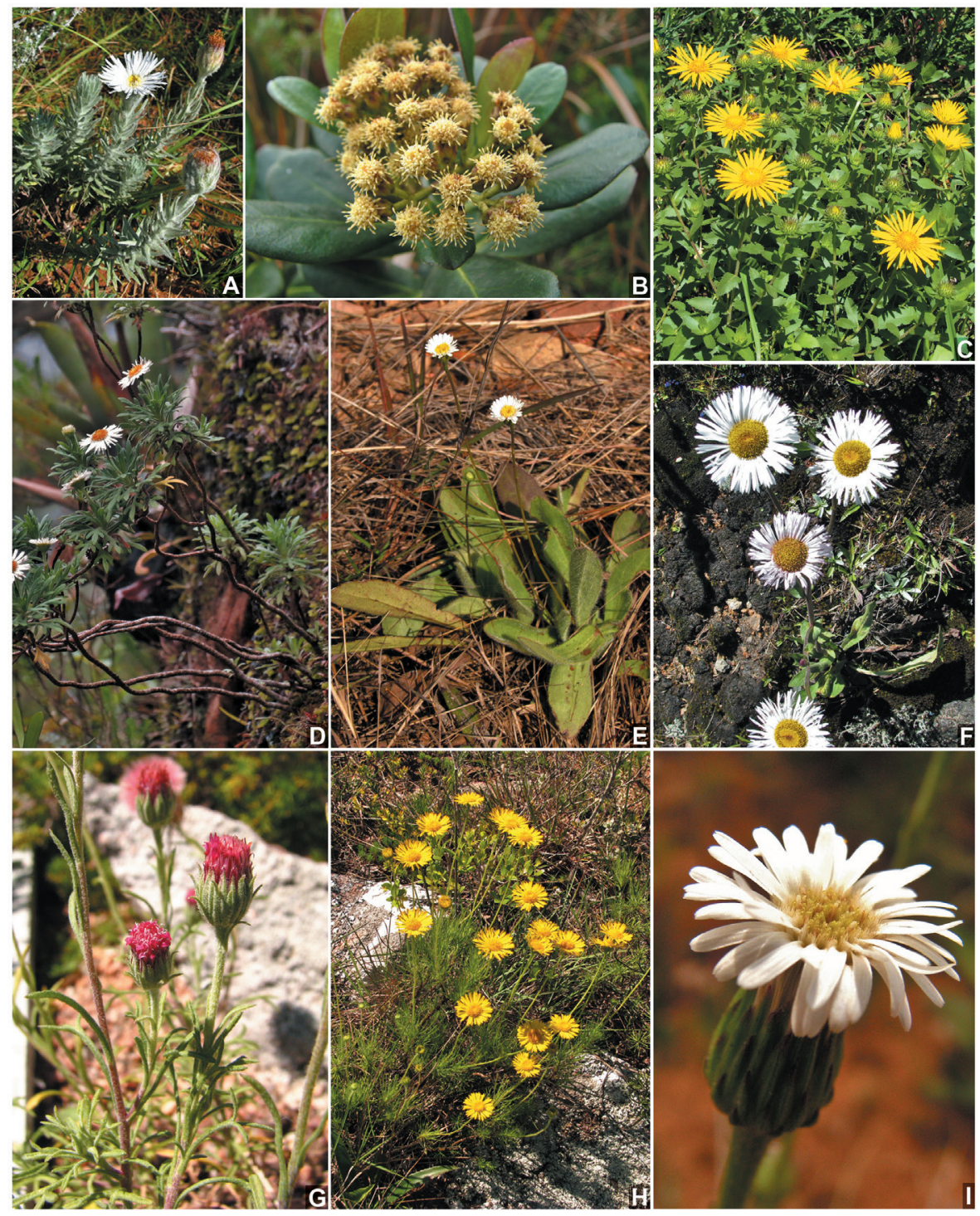

Figura 15. Astereae. A. Asteropsis megapotamica (Spreng.) Marchesi et al.; B. Baccharis macrophylla Dusén; C. Grindelia puberula Hook. \& Arn.; D. Hysterionica pinnatiloba Matzenb. \& Sobral; E. Inulopsis scaposa (DC.) O. Hoffm.; F. Leptostelma camposportoi (Cabrera) A.M. Teles \& Sobral; G. Microgyne trifurcata Less.; H. Neja filiformis (Spreng.) Nees; I. Podocoma bellidifolia Baker. 


\section{TRIBO ANTHEMIDEAE CASS.}

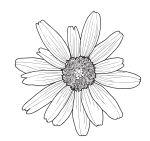

Angelo Alberto Schneider

Anthemideae está representada por 111 gêneros e cerca de 1.800 espécies (OBERPRIELER; VOGT; WATSON, 2007), sendo que a maior concentração de seus táxons está na Ásia Central, Mediterrâneo e sul da África.

A tribo caracteriza-se por apresentar lâmina foliar com margem 1-3-dividida, palmada ou pinatífida, sendo os lóbulos externos usualmente lineares a filiformes, algumas vezes denteada ou ainda inteira, brácteas involucrais em 2-7 séries desiguais, pápus nulo ou formando por escamas, raramente cerdas.

\section{Descrição}

Ervas anuais, bianuais ou perenes, subarbustos ou arbustos; plantas com tricomas, raro ausentes, geralmente tricomas glandulares bisseriados em formato de " $\mathrm{T}$ " ou estrelados. Folhas comumente alternas, denteadas, serradas, lobadas, pinatífidas ou pinatissectas, raro inteiras. Capitulescência corimbiforme, paniculiforme, racemiforme ou glomeruliforme, laxa a congesta, ou capítulos solitários. Capítulos frequentemente pedunculados, radiados ou disciformes, heterógamos ou discoides homógamos; invólucros hemisféricos, obcônicos, cilíndricos ou urceolados; brácteas involucrais 2-7-seriadas, imbricadas, às vezes com canais de resina, quase sempre com margens e ápices escariosos; receptáculo plano, hemisférico, cônico, glabro ou piloso, paleáceo ou epaleáceo, páleas planas ou naviculares, persistentes ou não. Flores do raio pistiladas férteis, estéreis ou ainda neutras, limbo 
branco, amarelo, rosado ou avermelhado; flores mais externas do disco em 1 ou muitas séries, pistiladas, normalmente férteis; corola tubulosa e com 0-5 lobos apicais, amarelas, raro ausentes; flores centrais do disco bissexuais ou funcionalmente masculinas, corola tubular, infundibuliforme, actinomorfa, 3-6 lobos, amarela, raramente alva ou avermelhada; anteras com apêndice apical normalmente ovado, triangular, raro caudadas, colar da antera espesso, cilíndrico; estilete com base bulbosa ou lisa, geralmente inserida no estilopódio (nectário); ramos do estilete lineares, ápice truncado e penicilado. Cipsela obovoide, obcônica ou cilíndrica, geralmente costada, algumas aladas; pápus ausente ou coroniforme (escamas fundidas na base), ou ainda cerdas escamiformes.

A tribo Anthemideae está representada no Brasil por 10 gêneros, sendo que 9 são exóticos e apenas 1 é nativo, Soliva Ruiz \& Pav. A maioria refere-se a plantas exóticas e conhecidas por serem plantas aromáticas, com valor farmacêutico (Achillea L., Artemisia L., Matricaria L. e Tanacetum L.), ornamental (Chrysanthemum L. e Leucanthemum Mill.) ou ainda plantas subespontâneas (Anthemis L., Coleostephus Cass., Cotula L. e Soliva Ruiz \& Pav.). Representantes de Anthemideae são encontrados na Figura 16A-F.

\section{Chave de identificação para os gêneros de Anthemideae no Brasil}

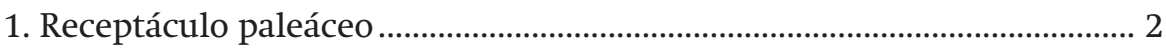

1'. Receptáculo epaleáceo .................................................................................... 4

2. Páleas restritas às flores marginais .............................................. Tanacetum

2'. Páleas em todo receptáculo ........................................................................... 3

3. Capitulescência corimbiforme, congesta; invólucro cilíndrico ......Achillea

3'. Capitulescência corimbiforme, laxa ou capítulos solitários; invólucro hemisférico Anthemis

4. Capítulos radiados; flores marginais com corola ligulada, conspícua (Figura 13L) 5

4'. Capítulos discoides ou disciformes; flores marginais com corola 3-denteada, filiforme ou ausentes 8 
5. Plantas anuais; de uso medicinal ou infestantes........................................... 6

5'. Plantas perenes; de uso ornamental .............................................................. 7

6. Capítulos com lígulas amarelas; cipselas 10-costadas............. Coleostephus

6'. Capítulos com lígulas brancas; cipselas 5-costadas.................... Matricaria

7. Folhas inteiras, dentado-serreadas ou parcialmente lobadas; cipselas 10-costadas, costas projetadas no ápice da cipsela em forma de anel

Leucanthemum

7'. Folhas pinatissectas, lobadas; cipselas 5-8-costadas, costas não projetadas no ápice da cipsela

Chrysanthemum

8. Capitulescência paniculiforme

Artemisia

8'. Capítulos solitário. 9

9. Capítulos sésseis; estiletes das flores pistiladas persistentes e espinescentes no fruto Soliva

9'. Capítulos pedunculados; estiletes das flores pistiladas não persistentes no fruto Cotula

\section{Literatura recomendada}

BARKLEY, T. M.; BROUILLET, L.; STROTHER, J. L. Anthemideae. In: FLORA OF NORTH AMERICA EDITORIAL COMMITTEE. Flora of North America. Oxford: Oxford University Press, 2006. v. 19, p. 485-486.

CABRERA, A. L. Compositae. In: BURKART, A. (Org.). Flora ilustrada de entre rios (Argentina). Buenos Aires: Colecion Cientifica del INTA, 1974.

p. 106-554.

LIN, Y. R. et al. Anthemideae. In: WU, Z. Y.; RAVEN, P. H.; HONG, D. Y. (Ed.). Flora of China (Asteraceae). St. Louis: Science Press (Beijing) \& Missouri Botanical Garden Press, 2011. v. 20-21, p. 653-773.

OBERPRIELER, C; R. VOGT, C. O.; WATSON, L. E. Tribe Anthemideae. In: KADEREIT, J. W.; JEFFREY, C. (Ed.). The Families and Genera of Vascular Plants: v. VIII: Flowering Plants: Eudicots - Asterales. Berlin: Springer-Verlag, 2007. p. 342-374. 


\title{
TRIBO INULEAE CASS.
}

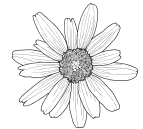 \\ Marcelo Monge \\ Arne A. Anderberg \\ João Semir
}

Inuleae foi estabelecida por Cassini (1819) como a $12^{\mathrm{a}}$ tribo de Asteraceae. Posteriormente, alguns autores propuseram novas classificações para a família incluindo a tribo Inuleae (CANDOLLE, 1836; HOFFMANN, 1890; LESSING, 1832); entretanto, foi a classificação de Bentham (1873) que perdurou por mais de um século. Bentham (1873), em seu trabalho, reorganizou a tribo Inuleae em 9 subtribos, baseando-se na sexualidade das flores, morfologia dos ramos do estilete e presença ou ausência de páleas no receptáculo.

Quase um século depois, Merxmüller, Leins e Roessler (1977) discutiram que as classificações propostas para a tribo não refletiam grupos naturais, pois estas apresentavam grande sobreposição de caracteres diagnósticos e outras incongruências. Assim, Merxmüller, Leins e Roessler (1977) recircunscreveram Inuleae com base nos seguintes caracteres diagnósticos: presença de anteras caudadas, às vezes sagitadas; flores com corola amarela, com heterogamia predominante; ramos do estilete agudos; pápus plumoso. Esses mesmos autores também propuseram 3 subtribos: Inulinae s.l., Gnaphaliinae s.l. e Athrixiinae s.l. Por fim, Merxmüller, Leins e Roessler (1977) reconheceram que, mesmo no sistema proposto, ainda persistiam problemas de delimitação nas subtribos e em alguns gêneros.

Bremer (1987), ao estudar as relações filogenéticas da família Asteraceae com base em dados morfológicos, concluiu que a tribo Inuleae sensu Merxmüller, Leins e Roessler (1977) era parafilética, uma vez que os 
representantes estavam inseridos em 3 subgrupos: Inuleae-Plucheinae s.l., Inulinae s. str. e Gnaphalieae. Posteriormente, Anderberg (1989) realizou outro estudo filogenético, também baseado em caracteres morfológicos, que subsidiou uma nova circunscrição da tribo Inuleae, segregando membros de Inuleae-Plucheinae s.l. em uma nova tribo, Plucheae (Benth.) A. Anderb., e restabelecendo a tribo Gnaphalieae Rydb. Estudos filogenéticos posteriores baseados em caracteres moleculares evidenciaram que Inuleae e Plucheae formam um grupo monofilético subordinado à subfamília Asteroideae (ANDERGERG et al., 2005; BAYER; STAR 1998; ELDENÄS; KALLESRJÖ; ANDERBERG, 1999; KIM; JANSEN, 1995; NYLINDER; ANDERBERG, 2015). Dessa forma, Anderberg e Eldenäs (2007) alteraram o status de Plucheae, posicionando-a como uma subtribo de Inuleae, sendo assim aceita até o presente.

A tribo Inuleae possui 66 gêneros e cerca de 690 espécies, com distribuição tropical, subtropical e temperada. A maioria das espécies da tribo ocorre na Eurásia, sul e leste da África (ANDERBERG; ELDENÄS, 2007), sendo a região mediterrânea considerada o centro de diversidade do grupo (ANDERBERG, 2009). Cerca de metade dos gêneros da tribo é monoespecífico ou possui 2 espécies. A circunscrição da tribo tem mudado muito nas últimas décadas e, atualmente, a tribo é caracterizada pela presença de ductos resiníferos no caule, ausência de ductos laticíferos, ausência de fibras no floema, antera com base caudada, ramos do estilete obtusos, pólen caveado e equinado, com exina microperfurada (ANDERBERG 2009; ANDERBERG; ELDENÄS 2007).

\section{Descrição}

Árvores, arbustos, subarbustos, ervas anuais ou perenes, monoicas, andromonoicas ou ginomonoicas; raízes fasciculadas, rizomatosas, tuberosas ou xilopodiais; ramos alados ou não, com ductos resiníferos. Folhas alternas, subopostas, lâminas inteiras, pinatífidas, ou pinatissectas, margens inteiras, serreadas ou denteadas, glabras ou com indumento. Capitulescência racemiforme, corimbiforme, paniculiforme, espiciforme, em glomérulo, capitulescência de segunda ordem, em racemo ou corimbo 
espiciforme, racemos de glomérulo, corimbo espiciforme ou de glomérulo ou capítulos solitários. Capítulos homógamos ou heterógamos, radiados, discoides ou disciformes; involucro multisseriado; receptáculo plano, convexo ou côncavo, paleáceo ou epaleáceo. Flores dimórficas, raramente isomórficas, e se dimórficas, flores do raio pistiladas ou neutras, unisseriadas ou plurisseriadas, corola ligulada, tubulosa ou tubuloso-filiforme, amarela, rósea, lilás, roxa ou branca; flores do disco bissexuais ou funcionalmente masculinas, corola tubulosa, amarela, rósea, lilás, roxa ou branca; anteras caudadas, ecalcaradas, raramente calcaradas, apêndices basais longos ou curtos, lineares, bífidos ou não; estilete bífido ou indiviso, em flores com gineceu abortado, superfície papilosa ou com tricomas pubescentes abaixo da ramificação. Cipselas elipsoides, turbinadas, costadas, glabras ou com indumento, células epidérmicas com ou sem cristais de oxalato de cálcio; pápus cerdoso e/ou escamoso, ou ausente.

A tribo Inuleae está representada no Brasil por 5 gêneros e 22 espécies ocorrendo nas províncias fitogeográficas da Amazônia, caatinga, cerrado, floresta atlântica, pampa e pantanal. O pampa é a província fitogeográfica com maior diversidade de espécies no país. Algumas espécies podem ocorrer em ambientes antropizados. Epaltes Cass. é um gênero com distribuição pantropical (ANDERBERG, 2009) e, no Brasil, possui uma única espécie, ocorrente em áreas úmidas, alagadas e à beira de riachos nas províncias do Amazonas, caatinga e pantanal; Pluchea Cass. possui distribuição cosmopolita (ANDERBERG, 2009), e as 3 espécies ocorrentes no Brasil estão dispersas no cerrado, floresta atlântica, pampa e também em ambientes antropizados (Figura 16G); Pterocaulon Elliot ocorre nas Américas e Australásia (CABRERA; RAGONESE, 1978), e, no Brasil, é o gênero que apresenta maior diversidade, com 11 espécies, e distribuição mais ampla, estando presente no cerrado, floresta atlântica brasileira, pampa, pantanal e áreas antropizadas (Figura $16 \mathrm{H})$; Stenachaenium Benth. é um gênero sul-americano restrito ao cone sul, e as 5 espécies do Brasil ocorrem no pampa (ANDERBERG, 2009) (Figura 16I); Tessaria Ruiz \& Pav. possui 2 espécies no Brasil, ambas na província do pampa (BFG, 2015). 


\section{Chave de identificação para os gêneros de Inuleae para o Brasil}

1. Pápus ausente Epaltes

1’. Pápus presente 2

2. Capítulos sésseis, capitulescência racemiforme, panículas espiciformes ou glomeruliformes Pterocaulon

2'. Capítulos pedunculados, organizados em capitulescência 3

3. Folhas basais em roseta; flores do disco bissexuais Stenachaenium

3'. Folhas basais alternas; flores do disco masculinas por aborto do gineceu 4

4. Caule alado; flores do disco numerosas, 25-50 por capítulo. Pluchea 4'. Caule cilíndrico (não alado); flores do disco poucas, 1-15 por capítulo..... Tessaria

\section{Literatura recomendada}

ANDERBERG, A. A. Inuleae. In: V.A. FUNK; A. et al. Systematics, Evolution, and Biogeography of Compositae. Viena: IAPT, 2009. p. 667-680.

ANDERBERG, A. A. Phylogeny and reclassification of the tribe Inuleae (Asteraceae). Canadian Journal of Botany, Ottawa, v. 67, n. 8, p. 2277-2296, 1989.

ANDERBERG, A. A.; ELDENÄS, P. Tribe Inuleae. In. KUBITZKI, K.;

KADEREIT, J. W.; JEFFREY, C. (Ed.). The Families and Genera of Vascular Plant: v. VIII: Flowering Plants Eudicots: Asterales. Berlin: Springer-Verlag, 2007. p. 374-391.

ANDERBERG, A. A. et al. Evolutionary relationships in the Asteraceae tribe Inuleae (Incl. Plucheae) evidenced by DNA sequences of ndhF, with notes on the systematic position of some aberrant genera. Organism, Diversity and Evolution, Jena, v. 5, n. 2, p. 135-146, 2005. 
BAYER, R. J.; STAR, J. R. The phylogeny of Asteraceae based on two noncodding chloroplast sequences, the trnL intron and $\operatorname{trnL} / \operatorname{trnF}$ intergenic spacer. Annals of the Missouri Botanical Garden, Saint Louis, v. 85, n. 2, p. 242-256, 1998.

BENTHAM, G. Compositae. In: BENTHAM, G.; J. D. HOOKER (Ed.). Genera Plantarum. London: Lovell Reeve, 1873. p 180-189.

BREMER, K. Tribal interrelationships of Asteraceae. Cladistics, Westport, v. 3, n. 3, p. 210-256, 1987.

CABRERA, A. L.; RAGONESE, A. M. Revisión del género Pterocaulon (Compositae). Darwiniana, v. 21, p. 185-257, 1978.

CASSINI, H. Suit du sixiéme mémoire sur la familie des Synanthérées, contenat les caractères des tribus. Journal de Physique, de Chimie, d'Histoire Naturelle et des Arts 88, Paris, p. 189-204, 1819.

CANDOLLE, A. de. Prodromus Systematis Naturalis Regni Vegetabilis. Paris: Treutel \& Würtz, 1836. Pars. 5.

ELDENÄS, P.; KALLESRJÖ, M.; ANDERBERG, A. A. Phylogenetic placement and circunscription Inuleae s.str. and Plucheae (Asteraceae): evidence from sequences gene ndhF. Molecular Phylogenetics and Evolution, Orlando, v.13, p. 50-58, 1999.

HOFFMANN, O. Compositae. In: ENGLER, A.; PRANTL, K. Die Natürlichen Pflanzenfamilien. Leipzig: W. Engelmann, 1890. v. 4, p. 87-391.

KIM, K. J.; JANSEN, R. K. ndhF sequence evolution and the major clades in the sunflower family. Proceedings of the National academy of Science of the United States of America, Washington, v. 92, n. 22, p. 10379-10383, 1995.

LESSING, C. F. Synopsis Generarum Compositarum. Berlin: Dunker \& Humboldt, 1832.

MERXMÜLLER, H.; LEINS, P.; ROESSLER, H. Inuleae-Systematic Review. In: HEYWOOD, V. H.; HARBONE, J. B.; TURNER, B. L. (Ed.). Biology and Chemestry of Asteraceae. London: Academic Press, 1977. p. 577-602.

NYLINDER, S.; ANDERBERG, A. A. Phylogeny of the Inuleae (Asteraceae) with special emphasis in Inuleae-Plucheainae. Taxon, Utrecht, v. 64, n. 1, p. 110-130, 2015. 

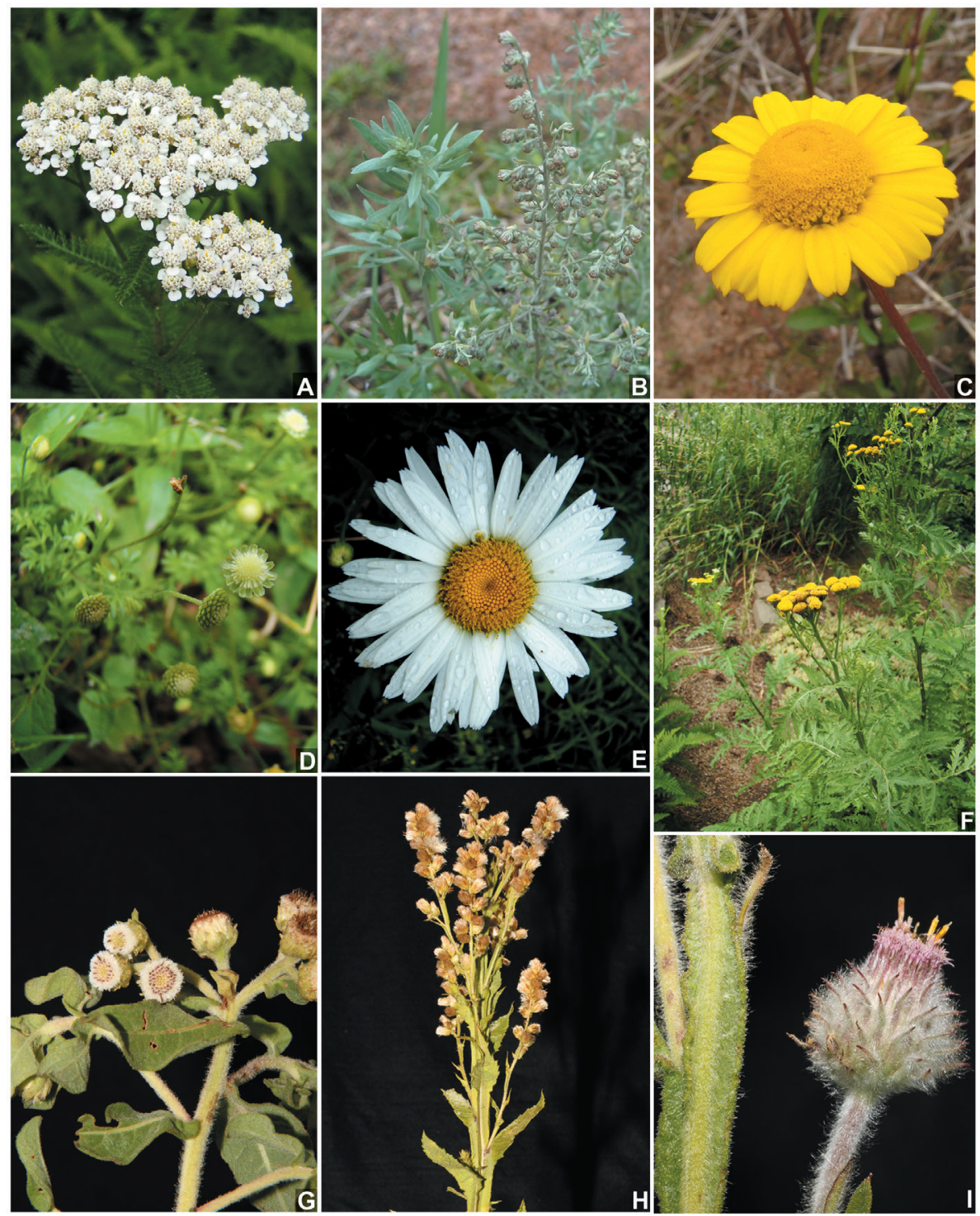

Figura 16. Anthemideae. A. Achillea millefolium L.; B. Artemisia sp.; C. Coleostephus myconis (L.) Cass.; D. Cotula australis (Sieber ex Spreng.) Hook. f.; E. Leucanthemum vulgare Lam.; F. Tanacetum vulgare L. Inuleae. G. Pluchea sagittalis (Lam.) Cabrera; H. Pterocaulon polystachyum DC.; I. Stenachaenium megapotamicum (Spreng.) Baker. 


\section{TRIBO HELENIEAE LINDL.}

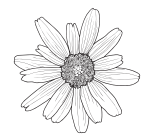

Maria Alves

João Bernardo de A. Bringel Jr.

Mara Angelina Galvão Magenta

Bentham (1873) reuniu na tribo Helenieae ("Helenioideae") todos os gêneros que possuíam receptáculo epaleáceo e pápus de páleas, que antes pertenciam a Heliantheae sensu Cassini (1819). Helenieae foi considerada por diversos autores (CRONQUIST, 1955; STUESSY, 1977; TURNER; POWELL, 1977, ROBINSON, 1981) como um conjunto não natural de gêneros, o que resultou na inserção desses táxons em várias tribos, principalmente Heliantheae e Senecioneae. Posteriormente, através de estudos moleculares (BALDWIN; WESSA, 2000, BALDWIN; WESSA; PANERO, 2002), Helenieae foi recircunscrita em 5 subtribos, incluindo 13 gêneros que correspondem às subtribos Gaillardinae e Marshallinae de Heliantheae sensu Robinson (1981). O tratamento taxonômico para a tribo, com chaves e descrição dos gêneros, foi apresentado por Panero (2007). Segundo esse autor, a maioria das Helenieae pode ser distinguida dos outros táxons da Aliança Heliantheae por não possuir cipselas enegrecidas, e sim com ráfides em suas células epidermais, e por, geralmente, apresentar folhas alternas, flores do raio com ápice do limbo conspicuamente trilobado, ramos do estilete truncados e pápus de páleas.

Helenieae possui, atualmente, 13 gêneros e cerca de 120 espécies, distribuídas no norte e no sul do continente americano, com a maior parte das espécies no sudoeste dos Estados Unidos e norte do México (PANERO, 2007). 


\section{Descrição}

Ervas bianuais, anuais ou perenes, raramente arbustos. Folhas alternas, raramente opostas, às vezes em rosetas basais, pecioladas, subsésseis ou sésseis, lâmina foliar inteira a pinatissecta, linear a lanceolada, raramente ovada, glabra a densamente lanosa. Capitulescência terminal, escaposa ou em cimeiras paniculiformes ou corimbiformes. Capítulos radiados ou discoides, invólucro cilíndrico, campanulado ou hemisférico; brácteas involucrais em 2-várias séries, subiguais ou gradativamente maiores, às vezes reflexas na antese; receptáculo plano a convexo, cônico ou globoso, geralmente epaleáceo. Flores do raio férteis ou neutras, geralmente com 3-5 lacínias; flores do disco bissexuais, raramente funcionalmente estaminadas, corolas tubulares a campanuladas, glabrescentes a densamente pubescentes; anteras curtamente caudadas a ecaudadas, apêndices do conectivo estreitamente ovados a arredondados e fortemente carenados; estilete geralmente truncado com um tufo de papilas, às vezes com um apêndice cônico, vascularizado (Balduina, Gaillardia) ou com uma proliferação de células que formam um ápice obtuso. Cipselas do raio e do disco homomórficas, clavadas a subcilíndricas, com ráfides nas células epidermais, glabras a seríceas; pápus cerdoso, cerdas livres ou fundidas, ou paleáceo, páleas oblongas, ovadas, obtusas, erosas, aristadas ou acuminadas, raramente sem pápus.

No Brasil, Helenieae está representada por 3 gêneros, Hymenoxys Cass. (2 spp.), Gaillardia Foug. (2 spp.) e Helenium L. (1 spp.).

\section{Chave de identificação para os gêneros de Helenieae no Brasil}

1. Lâminas foliares pinatissectas e alternas ao longo do caule; receptáculo plano ou cônico Hymenoxys 1'. Lâminas foliares inteiras; quando pinatissectas, formam rosetas basais; receptáculo convexo, subgloboso ou globoso 
2. Receptáculo alveolado, geralmente com projeções (Figura 13M); pápus com 6-9 páleas finas, com nervura central que excede a pálea, formando uma arista (Figura $13 \mathrm{~N}$ ). Gaillardia 2'. Receptáculo liso; pápus com 5 páleas acuminadas ou curto-aristadas ..... Helenium

\section{Literatura recomendada}

BAKER, J. G. Hymenoxys.. In: MARTIUS, C. P. von; EICHLER, A. W. (Ed.). Flora Brasiliensis. Leipzig: F. Fleischer, 1884. v. 6, pt. 3, p. 277-278.

BALDWIN, B. G.; WESSA, B. L. Phylogenetic placement of Pelucha and new subtribes in Helenieae sensu stricto (Compositae). Systematic Botany, Kent, v. 25, n. 3, p. 522-538, 2000.

BALDWIN, B. G.; WESSA, B. L; PANERO, J. L. Nuclear rDNA evidence for major lineages of helenioid Heliantheae (Compositae). Systematic Botany, Kent, v. 27, n. 1, p. 161-198, 2002.

BENTHAM, G. Notes on the classification, history and geographical distribution of Compositae. Journal of the Linnean Society Botany, London, v. 13, n. 70/72, p. 335-577, 1873.

BIDDULPH, S. F. A revision of the genus Gaillardia. Research Studies of the State College of Washington, Washington, v. 12, p. 195-256, 1944.

BIERNER, M. W. Taxonomy of Helenium Sect. Tetrodus and a conspectus of North American Helenium (Compositae). Brittonia, New York, v. 24, n. 4, p. 331-335, 1972.

CARNEIRO, C. R.; RITTER, M. R. A tribo Helenieae Benth. \& Hook. s. s. (Asteraceae) no sul do Brasil. Revista Brasileira de Biociências, Porto Alegre, v. 15, n. 1, p. 7-18, 2017.

CASSINI, H. Suit du Sixième mémoire sur la famille des Synanthérées, contenant les caractères des tribus. Journal de Physique, de Chimie, d'Histoire Naturelle et des Arts, Paris, t. 88, p. 150-163, 1819. 
CRONQUIST, A. J. Phylogeny and taxonomy of the Compositae. American Midland Naturalist, Notre Dame, v. 53, p. 478-511, 1955.

MARLOWE, K.; HUFFORD, L. Taxonomy and biogeography of Gaillardia (Asteraceae): A Phylogenetic Analysis. Systematic Botany, Kent, v. 32, n. 1, p. 208-226, 2007.

PANERO, J. L. Tribe Helenieae Cass. In: KUBITZKI, K. (Ed.). The Families and Genera of Vascular Plant: v. VIII: Flowering Plants Eudicots: Asterales. Berlin: Springer-Verlag, 2007. p. 400-406.

ROBINSON, H. A revision of the tribal and subtribal limits of the Heliantheae (Asteraceae). Washington: Smithsonian Institution Press, 1981. (Smithsonian Contributions to Botany, v. 51).

STUESSY, T. F. Heliantheae - systematic review. In: HARBORNE, J.; TURNER, B. L; HEYWOOD, V. (Ed.). The biology and chemistry of the Compositae. London: Academic Press, 1977. v. 2, p. 621-671.

TURNER, B. L.; POWELL, A. M. Helenieae - systematic review. In: HARBORNE, J.; TURNER, B. L; HEYWOOD, V. (Ed.). The biology and chemistry of the Compositae. London: Academic Press, 1977. p. 699-737.

TURNER, B. L.; WHALEN M. Taxonomic study of Gaillardia pulchella (Asteraceae-Heliantheae). Wrightia, Renner, v. 5, p. 189-192, 1975. 


\title{
TRIBO COREOPSIDEAE LINDL.
}

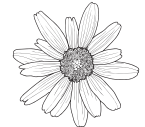 \\ Mara Angelina Galvão Magenta \\ Maria Alves \\ João Bernardo de A. Bringel Jr.
}

Coreopsideae foi proposta por Lindley (1829) para abranger 9 gêneros: Bidens L., Coreopsis L., Cosmos Cav. (Cosmea), Dahlia Cav., Heterosperma Cav., Parthenium L., Silphium L., Synedrella Gaertn. e Tetragonotheca L. Com base na circunscrição de Lessing (1830), que tratou o grupo como subtribo de Heliantheae (Coreopsidinae), Turner e Powell (1977) recircunscreveram a tribo Coreopsideae com a inclusão da subtribo Jaumeinae. A sugestão não foi bem aceita na comunidade científica, que passou a adotar o tratamento de Stuessy (1977), no qual Coreopsidinae foi considerada como subtribo de Heliantheae, incluindo 15 gêneros. No entanto, estudos moleculares (GOERTZEN et al., 2003; JANSEN et al., 1991; KIM et al., 1992; KIMBALL; CRAWFORD, 2004; PANERO; FUNK, 2002) corroboraram o status de tribo, e tal posicionamento foi adotado por Funk e colaboradores (2005) e Crawford e colaboradores (2009), que reconheceram a existência de 24 gêneros pertencentes à tribo.

Coreopsideae pode ser artificialmente delimitada pela presença de um conjunto de caracteres morfológicos, como as brácteas involucrais externas diferenciadas em forma e cor, a presença de estrias (ductos resiníferos) castanho-alaranjadas nas brácteas internas, pelas páleas do receptáculo lineares a lanceoladas com estrias contínuas às brácteas internas, pelas anteras e cipselas enegrecidas ou marrons e pelo pápus frequentemente de escamas ou aristas com tricomas antrorsos ou retrorsos (CRAWFORD et al., 2009; ROBINSON, 1981). 
As análises moleculares de Kimball e Crawford (2004) apontaram para o polifiletismo dos 2 maiores gêneros da tribo: Bidens e Coreopsis, que, futuramente, devem passar por reajustes em suas circunscrições taxonômicas. Por outro lado, o gênero Cosmos, que alguns autores consideram como sinônimo de Bidens, emergiu nas análises como monofilético. Segundo Crawford e colaboradores (2009), o maior desafio será encontrar características diagnósticas para os clados fortemente corroborados nos estudos filogenéticos moleculares já efetuados.

Em sua circunscrição atual (CRAWFORD et al., 2009), a tribo é composta por 24 gêneros e entre 593 e 599 espécies, e seus representantes são primariamente americanos, com alguns nativos da Austrália (Diodontium F. Muell., Glossocardia Cass. e Trioncinia (F. Muell.) Veldkamp) e 1 da Índia e Sri Lanka (Moonia Arn.). Embora não sejam reconhecidos na circunscrição de Crawford e colaboradores (2009), os gêneros Pinillosia Ossa ex DC. e Staurochlamys Baker foram inseridos em Coreopsideae por Panero (2007), com base em dados moleculares preliminares ainda não publicados. Esses gêneros apresentam morfologia muito distinta em relação ao restante de Coreopsideae e, no caso de Staurochlamys, a adição de mais dados moleculares a novas análises ainda poderá suportar seu reconhecimento como uma linhagem distinta ou dentro de Neurolaeneae (PANERO, 2007).

\section{Descrição}

Ervas, arbustos ou raramente pequenas árvores ou trepadeiras, glabros ou com vários tipos de indumento. Folhas simples, lâmina foliar com margem inteira a 3-pinatissecta. Capitulescência cimosa ou corimbosa, ou capítulo solitário, invólucro cilíndrico ou hemisférico. Capítulos heterógamos ou homógamos, radiados ou discoides; brácteas involucrais uni a multisseriadas, brácteas externas verdes, lineares a ovais, brácteas internas com 1 a muitas estrias castanho-alaranjadas, margens escariosas, às vezes com brácteas intermediárias orbiculares e foliáceas (Staurochlamys); receptáculo achatado a cônico, com páleas. Flores do raio neutras ou pis- 
tiladas, corola amarela, laranja, branca, rosa ou púrpura; flores do disco monoclinas ou funcionalmente estaminadas, corola tubular ou abrindose por uma cavidade que atravessa o lado ventral (Fitchia), com (4-)5 lobos curtamente triangulares, amarela, laranja ou amarelo-alaranjada; anteras (4-)5, marrons ou enegrecidas, raramente amareladas, curtamente caudadas; estilete inteiro ou curto-bifurcado, ramos cônicos com papilas curtas ou penicelados. Cipselas dorsalmente achatadas ou colunares, enegrecidas, marrons, raramente amarelo-amarronzadas ou vermelho-amarronzadas, lisas a estriadas, com ou sem alas; pápus de 2-8 aristas, lisas ou com cerdas antrorsas ou retrorsas, raramente com escamas, ou pápus ausente.

No Brasil, ocorrem 7 gêneros e cerca de 31 espécies, dos quais: Bidens, com 19 espécies (7 das quais são endêmicas), distribuído por todos os domínios fitogeográficos (Figuras 18A-C); Chrysanthellum Rich., representado por 1 única espécie encontrada em cerrado s.l.; Cosmos, com 3 espécies subespontâneas encontradas nos domínios da caatinga, cerrado, mata atlântica, pampa e pantanal (Figuras 18D-F); Coreopsis, com 1 espécie restrita ao Rio Grande do Sul; Isostigma Less., com 5 espécies encontradas nos domínios do cerrado e do pampa, 4 delas sendo endêmicas do país (Figura 18E); além de Staurochlamys, monoespecífico e endêmico do cerrado brasileiro e espécies ornamentais de Dahlia.

\section{Chave de identificação para os gêneros de Coreopsideae no Brasil}

1. Capítulos com 1 par de brácteas intermediárias nitidamente maiores que as demais, foliáceas e orbiculares. Flores do raio com pontuações glandulares Staurochlamys

1'. Capítulos sem par de brácteas involucrais foliáceas orbiculares. Flores do raio, quando presentes, sem pontuações glandulares.

2. Folhas em roseta basal 3

2'. Folhas opostas a alternas ao longo dos ramos 4 
3. Flores do raio com corola geralmente amarela; cipselas heteromorfas, cipselas do raio clavadas, sem pápus e cipselas do disco compressas, aladas, sem pápus ou raramente com pápus diminuto coroniforme ou de 2 aristas decíduas Chrysanthellum

3'. Flores do raio com corola geralmente roxa, amarelo-arroxeada ou atropurpúrea; cipselas isomorfas compressas, tetragonais, planas ou oblongas, sem alas ou com margem hialina estreita, pápus 2-aristado. Isostigma

4. Cipselas do disco geralmente aladas, de superfície rugosa a papilosa, com pápus de escamas caducas ou aristas com tricomas antrorsos Coreopsis 4'. Cipselas do disco sem alas, de superfície sulcada a finamente estriada, com pápus de aristas com tricomas retrorsos ou cerdas, ou cipselas sem pápus. 5

5. Flores do raio em mais de 3 séries; cipselas do disco de seção transversal compressa, sem pápus ou com pápus de 2 cerdas delicadas, caducas

Dahlia

5'. Flores do raio, quando existentes, em 1 ou 2 séries; cipselas do disco com seção transversal 4-angular, pápus de aristas com tricomas retrorsos ou raramente cipselas sem pápus 6

6. Cipselas sem rostro (Figura 15A); estames com filetes glabros Bidens 6'. Cipselas com rostro alongado (Figura 15B); estames com filetes hirsutos Cosmos

\section{Literatura recomendada}

BRINGEL JR., J. B. A., PASTORE, J. F. B.; CAVALCANTI, T. B. An unusual new species of Bidens (Asteraceae, Coreopsideae) with its phylogenetic position and taxonomic notes. Systematic Botany, Kent, v. 42, n. 2, p. 301-312, 2017.

CRAWFORD, D. J., et al. Coreopsideae. In: FUNK, V. A. et al. (Ed.). Systematics, Evolution and Biogeography of Compositae. Vienna: IAPT, 2009. p. 713-730.

CRAWFORD, D. J. et al. Coreopsis sect. Pseudoagarista (Asteraceae: Coreopsideae): Molecular phylogeny, chromosome numbers, and 
comments on taxonomy and distribution. Taxon, Utrecht, v. 63, n. 5, p. 1092-1102, 2014.

FUNK, V. A. et al. Everywhere but Antarctica: using a supertree to understand the diversity and distribution of the Compositae. Biologiske Skrifter, Copenhagen, n. 55, p. 343-374, 2005.

GOERTZEN, L. R. et al. ITS secondary structure derived from comparative analysis: implications for sequence alignment and phylogeny of Asteraceae. Molecular Phylogenetics and Evolution, Orlando, v. 29, n. 5, p. 216-234, 2003.

JANSEN, R. K. et al. Phylogeny and character evolution in the Asteraceae based on chloroplast DNA restriction site mapping. Systematic Botany, Kent, v. 16, p. 98-115, 1991.

KIM, K. J., R. K. et al. Phylogenetic implications of rbcL sequence variation in the Asteraceae. Annals of the Missouri Botanical Garden, Saint Louis, v. 79, n. 2, p. 428-445, 1992.

KIMBALL, R. T.; CRAWFORD, D. J. Phylogeny of Coreopsideae (Asteraceae) using ITS sequences suggests lability in reproductive characters. Molecular Phylogenetics and Evolution, Orlando, v. 33, n. 1, p. 127-139, 2004.

LESSING, C.F. Synanthereae. Linnaea, [S.1.], n. 5, p. 72-174, 1830.

LINDLEY, J. Suborder XVII. Heliantheae. In: LOUDON, J. C. (Ed.). An encyclopaedia of plants. London: Longman, Rees, Orme, Brown and Green, 1829. p. 1074.

MORT, M. E. et al. Phylogeny of Coreopsideae (Asteraceae) inferred from nuclear and plastid DNA sequences. Taxon, Utrecht, v. 57, n. 1, p. 109-112, 2008.

PANERO, J. L. Tribe Coreopsideae Lindl. In: KADERETT, J. W.; JEFFREY, C. (Ed.). The families and genera of vascular plant: v. VIII: Flowering plants eudicots: Asterales, Berlim: Springer, 2007. p. 406-417.

PANERO, J. L.; FUNK, V. A. Toward a phylogenetic subfamilial classification for the Compositae (Asteraceae). Proceedings of the Biological Society of Washington, Washington, v. 115, n. 4, p. 909-922, 2002. 
PETER, G. Systematic revision of the genus Isostigma Less. (Asteraceae, Coreopsideae). Candollea, Genebra, v. 64, n. 1, p. 5-30, 2009.

ROBINSON, H. A revision of the tribal and subtribal limits of the Heliantheae (Asteraceae). Washington: Smithsonian Institution Press, 1981.

(Smithsonian Contributions to Botany, v. 51).

SHERFF, E. E. Revision of the genus Isostigma Less. Botanical Gazette, Chicago, v. 81, n. 3, p. 241-257, 1926.

SHERFF, E. E. Revision of the genus Cosmos. Field Museum of Natural History, Botanical Series, Chicago, v. 8, n. 6, p. 441-447, 1932.

SHERFF, E. E. Revision of the genus Coreopsis. Field Museum of Natural History, Botanical Series, Chicago, v. 11, n. 6, p. 279-475, 1936.

SHERFF, E. E. The genus Bidens. Field Museum of Natural History, Botanical Series, Chicago, v. 16, p. 1-709, 1937.

SHERFF, E. E. Compositae - Heliantheae - Coreopsidinae. In: SHERFF, E. E.; ALEXANDER, E. J. (Eds.). North American Flora. New York: The New York Botanical Garden, 1955. v. 1, p. 1-149.

SMITH, E. B. A biosystematic survey of Coreopsis in eastern United States and Canada. Sida, Contributions to Botany, Dallas, v. 6, n. 3, p. 123-215, 1976.

SORENSEN, P. D. Revision of the genus Dahlia (Compositae - Heliantheae Coreopsidinae). Rhodora, Cambridge, n. 71, p. 367-416, 1969.

STUESSY, T. F. Heliantheae - systematic review. In: HEYWOOD, V. H.; HARBORNE J. B.; TURNER, E B. L. (Ed.). The Biology and chemistry of the Compositae. London: Academic Press, 1977. p. 621-671.

TADESSE, M.; CRAWFORD, D. J. The phytomelanin layer in traditional members of Bidens and Coreopsis and phylogeny of the Coreopsideae (Compositae). Nordic Journal of Botany, v. 32, p. 80-91, 2014.

TURNER, B. L. Taxonomic study of Chrysanthellum (Asteraceae, Coreopsideae). Phytologia, Huntsville, n. 64, n. 6, p. 410-444, 1988.

TURNER, B. L.; POWEL, M. A. Helenieae - systematic review. In: HEYWOOD, V. H.; HARBORNE, J. B.; TURNER, E. B. L. (Ed.). The Biology and chemistry of the Compositae. London: Academic Press, London: Academic Press, 1977. p. 699-737. 


\section{TRIBO NEUROLAENEAE RYDB.}

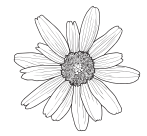

Nádia Roque

A partir dos estudos moleculares realizados por Panero e Funk (2002, 2008), Neurolaeneae foi elevada ao status de tribo e incluída na Aliança Heliantheae como grupo irmão de Bahieae, Chaenactideae e Tageteae. Atualmente, é circunscrita com 5 gêneros e cerca de 153 espécies, com a maioria representada nas áreas tropicais do México e América do Sul (PANERO, 2007).

A tribo caracteriza-se pelas flores do raio, se presentes, pistiladas, receptáculo geralmente paleáceo, anteras amarelas, cipselas enegrecidas e pápus geralmente de páleas ou escamas livres, raramente coroniforme ou ausente.

\section{Descrição}

Ervas, arbustos, raramente árvores, anuais ou perenes, monoicas. Folhas alternas ou opostas, raro verticiladas. Capitulescência paniculiforme ou corimbiforme ou capítulos terminais ou axilares, solitários em longos pedúnculos, discoides (Figura 17C) ou radiados; invólucro cilíndrico, campanulado ou hemisférico; brácteas involucrais em 1 a 8 séries, subiguais a graduadas; receptáculo plano a cônico (Figura 17D), geralmente paleáceo, páleas cartáceas. Flores do raio, quando presentes, pistiladas, corola liguliforme, amarela, raramente alva, conspícua ou algumas vezes pouco saliente às páleas; flores do disco bissexuais ou funcionalmente estaminadas, corola actinomorfa, (4-)5(-6) lobos, com canais de resina avermelhados ou alaranjados, amarela, raro alvo ou púrpura; anteras ecalcaradas, ecau- 
dadas, apêndice do conectivo deltado a ovalado, glandular abaxialmente; ramos do estilete agudos, papilosos. Cipselas obcônicas a obpiramidais, algumas vezes obcompressas, paredes carbonizadas, glabras a densamente pubescentes, algumas vezes com tricomas glandulares; pápus de cerdas, páleas ou escamas, subiguais ou desiguais, escamas algumas vezes fundidas na base, raramente coroniforme ou pápus ausente (Figura 17F).

No Brasil, a tribo está representada por 2 gêneros (Calea L. e Enydra Lour.) e cerca de 82 espécies distribuídas em todos os domínios fitogeográficos. Calea constitui mais de $80 \%$ da diversidade da tribo (BALDWIN, 2009), com cerca de 125 espécies e com distribuição neotropical, sendo que um grande número é registrado para o nordeste da América do Sul e Brasil (cerca de 80 spp.) (Figuras 18G-K) (PRUSKI; URBATSCH, 1988; WUSSOW; URBATSCH; SULLIVAN, 1985). Enydra apresenta 10 espécies pantropicais e, no Brasil, há registro de apenas 2, E. radicans (Willd.) Lack e E. anagallis Gardner com ampla distribuição.

\section{Chave de identificação para os gêneros de Neurolaeneae no Brasil}

1. Plantas terrestres; capítulos terminais, pedunculados; cipsela com pápus de escamas livres, raramente coroniforme com ápice eroso (Figura 17E) ..... .. Calea 1'. Plantas aquáticas ou de locais alagados; capítulos axilares, sésseis a subsésseis; cipsela com pápus coroniforme com ápice inteiro (Figura 17F) . Enydra

\section{Literatura recomendada}

BALDWIN, B. G. Heliantheae alliance. In: FUNK, V. A. et al. (Ed.). Systematics, Evolution and Biogeography of Compositae. Vienna: IAPT, 2009. Chapt. 41, p. 689-711. 
PANERO, J. L. Tribe Neurolaeneae Rydb. In: KADEREIT, J. W.; JEFFREY, C. (Ed.). The Families and Genera of Vascular Plant: v. VIII: Flowering Plants Eudicots: Asterales. Berlin: Springer, 2007. p. 417-420.

PANERO, J. L.; FUNK, V. A. The value of sampling anomalous taxa in phylogenetic studies: major clades of the Asteraceae revealed. Molecular Phylogenetics and Evolution, v. 47, p. 757-782, 2008.

PRUSKI, J. F. Calea brittoniana and Calea kristiniae: two new Compositae from Brazil. Brittonia, Bronx, v. 36, p. 98-103, 1984

PRUSKI, J. F. Novelties in Calea (Compositae: Heliantheae) from South America. Kew Bulletin, London, v. 53, n. 3, p. 683-693, 1998.

PRUSKI, J. F.; URBATSCH, L. E. Five new species of Calea (Compositae: Heliantheae) from Planaltine Brazil. Brittonia, London, v. 40, n. 4, p. 341-356, 1988.

PRUSKI, J. F.; HIND, D. J. N. Two new species of Calea (Compositae: Heliantheae) from Serra do Grão Mogol and vicinity, Minas Gerais, Brazil. Kew Bulletin, London, v. 53, n. 3, p. 695-701, 1998.

ROBINSON, H. Studies in the Heliantheae (Asteraceae). XIX. Four new species of Calea from Brazil. Phytologia, Huntsville, v. 44, p. 270-279, 1979a.

ROBINSON, H. Studies in the Heliantheae (Asteraceae). XXII. Two new species of Calea from Brazil. Phytologia, Huntsville, v. 44, p. 436-441, $1979 \mathrm{~b}$.

ROBINSON, H. Studies in the Heliantheae (Asteraceae). XXVII. A new species of Calea from Brazil. Phytologia, Huntsville, v. 47, 1980. p. 261-263. ROBINSON, H. Studies in the Heliantheae (Asteraceae). XXVIII. Additions to Calea and Ichthyothere from Brazil. Phytologia, Huntsville, v. 49, p. 10-13, 1981.

ROQUE, N.; CARVALHO, V. C. Estudos taxonômicos do gênero Calea (Asteraceae, Neurolaeneae) no estado da Bahia, Brasil. Rodriguésia, Rio de Janeiro, v. 62, n. 3, p. 547-561, 2011.

URBATSCH, L. E; ZLOTSKY, A.; PRUSKI, J. F. Revision of Calea sect. Lemmatium (Asteraceae: Heliantheae) from Brazil. Systematic Botany, Kent, v. 11, n. 4, p. 501-514, 1986. 
WUSSOW, J. R.; URBATSCH, L. E.; SULLIVAN, G. A. Calea (Asteraceae) in Mexico, Central America and Jamaica. Systematic Botany, Kent, v. 10, n. 3, p. 241-267, 1985. 


\title{
TRIBO TAGETEAE CASS.
}

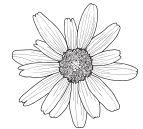 \\ João Bernardo de A. Bringel Jr. \\ Maria Alves \\ Mara Angelina Galvão Magenta
}

Embora Tageteae seja uma tribo reconhecida desde a época de Cassini (1819), alguns tratamentos taxonômicos, com base em características morfológicas e micromorfológicas (KARIS; RYDING, 1994; ROBINSON, 1981), divergiram quanto ao reconhecimento do grupo como tribo. Mesmo assim, esses autores mantiveram a ideia de que Tageteae seria um grupo natural, já que a maioria dos gêneros atualmente reconhecidos para a tribo estava inserida na subtribo Pectidinae de Heliantheae (ROBINSON, 1981) ou em Helenieae (KARIS; RYDING, 1994). Somente a partir das filogenias com base em dados moleculares de DNA nuclear ribossomal (BALDWIN; WESSA; PANERO, 2002) e de cloroplasto (PANERO; FUNK, 2002), a aceitação de Tageteae como tribo distinta foi consolidada.

A presença de cavidades secretoras (chamadas por alguns autores de glândulas pelúcidas) nas folhas e brácteas involucrais era uma característica comumente utilizada para reconhecer Tageteae (ou Pectidinae) (BARROSO et al., 1991; ROBINSON, 1981; STROTHER, 1977). No entanto, dados moleculares em estudos filogenéticos (BALDWIN; WESSA; PANERO, 2002) indicaram, embora com suporte estatístico não muito robusto, que a circunscrição da tribo deveria ser expandida, o que englobaria gêneros que não apresentam tais características. Os gêneros atualmente inseridos em Tageteae que não apresentam cavidades secretoras ou glândulas podem, em sua maioria, ser reconhecidos por apresentarem apêndice basal das anteras glabro, fortemente esclerificado, cipselas estriadas com carpopódio 
bem desenvolvido e, geralmente, pápus formado por cerdas ou escamas livres (PANERO, 2007).

Atualmente, Tageteae apresenta 32 gêneros e aproximadamente 270 espécies (BALDWIN, 2009; PANERO, 2007). Ocorre de forma predominante no México e porção sudoeste dos Estados Unidos, com representantes também na América do Sul e Caribe (BALDWIN, 2009, PANERO, 2007).

\section{Descrição}

Ervas a arbustos, raramente arvoretas, monoicas ou ginomonoicas. Folhas inteiras, pinadas ou bipinadas, alternas ou opostas, margem frequentemente com cavidade secretora (glândulas pelúcidas). Capitulescência cimosa, às vezes paniculiforme ou capítulos solitários. Capítulos geralmente radiados ou, de forma menos frequente, discoides; brácteas involucrais 1-4 séries, subiguais a gradativamente desiguais, livres ou conatas, frequentemente (apenas em Pectidinae) com cavidades secretoras ou glândulas infladas, às vezes com calículo 1-seriado; receptáculo plano ou cônico, epaleáceo ou raramente com pequenas escamas, cerdas ou faveolado. Flores do raio, quando presentes, pistiladas; flores do disco bissexuais, raramente funcionalmente estaminadas; corola actinomorfa, raramente zigomorfa, 5 lobos, raramente 4 ou 6 lobos; antera com apêndice do conectivo oval, deltoide, lanceolado ou inconspícuo, geralmente glabro e esclerificado, células do endotécio com espessamento polarizado, 0-2, 2-4 ou radialmente espessadas; ramos do estilete com ápice agudo ou atenuado, às vezes arredondado (em Pectis), linhas estigmáticas geralmente não confluentes no ápice, apêndices estéreis presentes ou não. Cipselas enegrecidas ou raramente marrons, cilíndricas a estreito-fusiformes ou piramidais, raramente comprimidas, estriadas, variadamente pubescentes; pápus formado por cerdas e/ou escamas livres, ocasionalmente escamas formando uma reduzida estrutura coroniforme, ou pápus ausente.

No Brasil, são encontrados 5 gêneros e 30 espécies: Flaveria Juss. (Flaveriinae), Jaumea Pers. (Jaumeinae), Pectis L., Porophyllum Guett. (Figuras 19A-B) e Tagetes L. (Figura 19C) (Pectidinae). 


\section{Chave de identificação para os gêneros de Tageteae no Brasil}

1. Plantas sem cavidades secretoras nas folhas e brácteas involucrais ....... 2 1'. Plantas com cavidades secretoras nas folhas ou nas brácteas involucrais

2. Capitulescência com capítulos discoides e radiados, frequentemente com apenas uma flor do raio; brácteas involucrais em 2 séries Flaveria 2'. Capitulescências apenas com capítulos discoides; brácteas involucrais em 3-4 séries Jaumea

3. Lâmina foliar com cerdas setosas nas margens; apêndice do conectivo da antera truncado; ramos do estilete curtos, de ápice arredondado ....... Pectis 3'. Lâmina foliar desprovida de cerdas nas margens; apêndice do conectivo da antera oval a lanceolado; ramos do estilete longos, de ápice agudo ou acuminado 4

4. Lâmina foliar geralmente pinatissecta; pápus formado por escamas (Figura 17G) Tagetes 4'. Lâmina foliar inteira; pápus formado por cerdas (Figura 17H)

Porophyllum

\section{Literatura Recomendada}

BALDWIN, B. G. Heliantheae alliance. In: FUNK, V. A. et al. Systematics, Evolution and Biogeography of Compositae. Vienna: IAPT, 2009. Chapt. 41, p. 689-711.

BALDWIN, B. G.; WESSA, B. L.; PANERO, J. L. Nuclear rDNA evidence for major lineages of helenoid Heliantheae. Systematic Botany, Kent, v. 27, n. 1, p. 161-198, 2002.

BARROSO, G. M. et al. Sistemática de angiospermas do Brasil. Viçosa: UFV, 1991. v. 3. 
BAUTISTA, H. P. Pectis L. (Compositae-Tageteae). Espécies ocorrentes no Brasil. Arquivos do Jardim Botânico do Rio de Janeiro, Rio de Janeiro, v. 28, p. 20-107, 1987.

CARNEIRO, C. R. As tribos Helenieae Benth \& Hook., sensu stricto, e Tageteae Cass., sensu lato, (Asteraceae) no Sul do Brasil. 2014. Dissertação (Mestrado em Botânica ) - Instituto de Biociências, Universidade Federal do Rio Grande do Sul, Porto Alegre, 2014.

CASSINI, H. Suit du Sixième mémoire sur la famille des Synanthérées, contenant les caractères des tribus. Journal de Physique, de Chimie, d'Histoire Naturelle et des Arts, Paris, t. 88, p. 150-163, 1819.

CORDAZZO, C. V.; CAETANO, V. L.; COSTA, C. S. B. Jaumea linearifolia (Juss.) DC. (Asteraceae), primeiro registro para o Brasil. Theringia, Porto Alegre, v. 62, n. 1/2, p. 99-102, 2007. Série Botânica.

HIND, D. J. N. A New species of Porophyllum (Compositae: Heliantheae) from Bahia, Brazil. Kew Bulletin, London, v. 57, n. 3, p. 705-709, 2002.

JOHNSON, R. R. Monograph of the plant genus Porophyllum (Compositae: Helenieae). The Universit of Kansas Science Bulletin, Lawrence, v. 48, n. 7, p. 225-267, 1969.

KARIS, P. O.; RYDING, O. Tribe Helenieae. In: BREMER, K. (Ed.). Asteraceae: cladistics and classification. Portland: Timber Press, 1994. p. 521-558.

PANERO, J. L. Tribe Tageteae Cass. In: KUBITZKI, K. (Ed.). The Families and Genera of Vascular Plant: v. VIII: Flowering Plants Eudicots: Asterales. Berlin: Springer-Verlag, 2007. p. 421-431.

PANERO, J. L.; FUNK, V. A. Toward a phylogenetic subfamilial classification for the Compositae (Asteraceae). Proceedings of the Biological Society of Washington, Washington, v. 115, n. 4, p. 909-922, 2002.

POWELL, A. M. Systematics of Flaveria (Flaveriinae-Asteraceae). Annals of the Missouri Botanical Garden, Saint Louis, v. 65, p. 590-636, 1978. 
ROBINSON, H. A revision of the tribal and subtribal limits of the Heliantheae (Asteraceae). Washington: Smithsonian Institution Press, 1981.

(Smithsonian Contributions to Botany, v. 51).

SOULE, J. Systematics of Tagetes (Asteraceae-Tageteae). 1993. 781 1. Thesis $(\mathrm{PhD})$ - University of Texas, Austin, 1993. $2 \mathrm{v}$.

STROTHER, J. L. Tageteae-systematic review. In: HEYWOOD, V. H.;

HARBONE, J. B.; TURNER, B. L. (Ed.). The Biology and Chemestry of the

Composite London: Academic Press, 1977.. v. 2. p. 769-783. 


\section{TRIBO BAHIEAE B.G. BALDWIN}

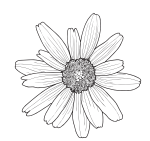

João Bernardo de A. BringelJr.

Maria Alves

Mara Angelina Galvão Magenta

Stuessy (1977) redelimitou a subtribo Bahiinae da tribo Heliantheae na tentativa de reconhecer um grupo natural. Seu conceito de Bahiinae englobava 11 gêneros, dos quais apenas 2 não estão inseridos na atual tribo Bahieae (BALDWIN, 2009; BALDWIN; WESSA; PANERO, 2002, PANERO, 2007). Tratamentos sistemáticos subsequentes ao de Stuessy (1977) para as tribos Heliantheae-Helenieae não consideraram Bahiinae como subtribo formal (KARIS; RYDING 1994, ROBINSON,1981). Apesar disso, Robinson (1981) reconheceu, dentro da subtribo Chaenactidinae, um grupo informal composto por 9 gêneros, que apresentam, em sua maior parte, células do endotécio curtas, dispostas em linhas regulares e com paredes transversais bem definidas. Todos esses gêneros estão atualmente inseridos em Bahieae (BALDWIN, 2009, PANERO, 2007), que teve seu reconhecimento consolidado como tribo a partir de estudos filogenéticos com dados moleculares de DNA (BALDWIN; WESSA; PANERO, 2002, PANERO; FUNK, 2002).

A maioria dos gêneros de Bahieae apresenta receptáculo epaleáceo, tricomas glandulares no apêndice do conectivo das anteras e corola, e cipselas de paredes estriadas (PANERO, 2007). A tribo também é bem caracterizada pela morfologia do pápus, que pode apresentar escamas com uma nervura central e a base espessada ou também cerdas ou aristas fasciculadas, às vezes de ápice uncinado (BALDWIN, 2009).

Bahieae está representada por 20 gêneros e 83 espécies, sendo a maioria distribuída na porção sudoeste dos Estados Unidos até a parte central 
do México (BALDWIN, 2009; PANERO, 2007). Poucos gêneros ocorrem na América do Sul e Índias Ocidentais (PANERO, 2007). Os únicos gêneros não americanos aceitos em Bahieae são Apostates N. S. Lander, endêmico da Polinésia Francesa, e Hypericophyllum Steetz, encontrado na África tropical, o que sugere eventos de longa dispersão (BALDWIN, 2009; PANERO, 2007).

\section{Descrição}

Ervas anuais a perenes, raramente arbustos. Folhas em rosetas ou ao longo dos ramos, alternas ou opostas, pecioladas ou sésseis, lâmina inteira ou 1-4-pinada, desprovidas de cavidades secretoras. Capitulescência corimbiforme, paniculiforme, ou capítulos solitários. Capítulos radiados, heterógamos ou discoides, homógamos, raramente disciformes, heterógamos (em Thymopsis); brácteas involucrais em 1-4 séries, muito semelhantes ou desiguais, imbricadas; receptáculo convexo ou plano, geralmente epaleáceo. Flores do raio pistiladas; flores do disco bissexuais, corola 4-5-lobada, actinomorfa, raramente zigomorfa; anteras de coloração pálida, avermelhada ou arroxeada; apêndice do conectivo geralmente oval, com ou sem tricomas glandulares; células do endotécio com espessamento polarizado (1-4) ou radial; estilete de base glabra, papilosa ou pubescente, ramos obtusos a acuminados, com ou sem apêndice. Cipselas enegrecidas, subcilíndricas a obpiramidais, 4-5 costas evidentes ou inconspícuas, paredes estriadas (exceto em Hymenopappus L' Hér. e Loxothysanus B. L. Rob.); pápus formado por escamas com ou sem nervura central, ocasionalmente escamas espessadas na base, cerdas ou aristas.

No Brasil, Bahieae é representada apenas pela espécie ruderal Schkuhria pinnata (Lam.) Kuntze ex Thell., que apresenta grande variação morfológica e pode ser dividida em 3 variedades. O táxon encontrado no país é Schkuhria pinnata var. pinnata, caracterizada por apresentar flores do raio de limbo linear (2-4 mm de comprimento) e cipselas de costas esparsamente pubescentes (TURNER, 1995). Foi coletada apenas no Distrito Federal e no estado de São Paulo. 


\section{Literatura recomendada}

BALDWIN, B. G. Heliantheae alliance. In: FUNK, V. A. et al. Systematics, Evolution and Biogeography of Compositae. Vienna: IAPT, 2009. Chapt. 41, p. 689-711.

BALDWIN, B. G.; WESSA, B. L.; PANERO, J. L. Nuclear rDNA evidence for major lineages of helenoid Heliantheae. Systematic Botany, Kent, v. 27, n. 1, p. 161-198, 2002.

HEISER JR., C. B. A revision of the genus Schkuhria. Annals of the Missouri Botanical Garden, Saint Louis, v. 32, n. 3, p. 265-278, 1945.

KARIS, P. O.; RYDING, O. 1994. Tribe Helenieae. In: BREMER K. (Ed.). Asteraceae: cladistics and classification. Portland: Timber Press, 1994. p. 521-558.

PANERO, J. L. Tribe Tageteae Cass. In: KUBITZKI, K. (Ed.). The Families and Genera of Vascular Plant: v. VIII: Flowering Plants Eudicots: Asterales. Berlin: Springer-Verlag, 2007. p. 421-431.

PANERO, J. L.; FUNK, V. A. Toward a phylogenetic subfamilial classification for the Compositae (Asteraceae). Proceedings of the Biological Society of Washington, Washington, v. 115, n. 4, p. 909-922, 2002.

ROBINSON, H. A revision of the tribal and subtribal limits of the Heliantheae (Asteraceae). Washington: Smithsonian Institution Press, 1981.

(Smithsonian Contributions to Botany, v. 51).

STUESSY, T. F. Heliantheae: systematic review. In: : HEYWOOD, V. H.; HARBONE, J. B.; TURNER, B. L. (Ed.). The Biology and Chemestry of the Composite.London: Academic Press, 1977. p. 621-671.

TURNER, B. L. Taxonomy and nomenclature of Schkuhria pinnata (Asteraceae, Helenieae). Phytologia, Huntsville, v. 79, p. 364-368, 1995. 


\section{TRIBO HELIANTHEAE CASS.}

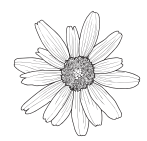

Mara Angelina Galvão Magenta

João Bernardo de A. Bringel Jr.

Maria Alves

A partir de estudos filogenéticos moleculares (PANERO; FUNK, 2002), Heliantheae sensu stricto foi recircunscrita incluindo a maioria dos táxons com receptáculo paleáceo e uma ampla diversidade de representantes lenhosos da Aliança Heliantheae (BALDWIN, 2009).

A caracterização morfológica da tribo, no entanto, é uma tarefa difícil devido ao elevado número de homoplasias morfológicas (PANERO, 2007). Contudo, seus representantes podem ser reconhecidos por um conjunto de características, como as brácteas involucrais frequentemente foliáceas, capítulos com receptáculo geralmente contendo páleas conduplicadas, quase sempre persistentes e envolvendo as flores do disco, anteras com apêndice geralmente oval e cipselas compressas com paredes impregnadas de fitomelanina (substância presente na maioria das tribos da Aliança Heliantheae, com exceção de Helenieae) (BALDWIN, 2009).

O sistema de classificação proposto por Panero (2007) divide Heliantheae em 14 subtribos, 113 gêneros e aproximadamente 1.500 espécies, com distribuição pantropical, em especial no México e nas Américas Central e do Sul.

\section{Descrição}

Ervas anuais ou perenes, arbustos, lianas ou árvores. Folhas alternas ou opostas, lâminas geralmente simples, raramente divididas, a maioria 
oval, 3-nervada, face adaxial geralmente escábrida. Capitulescência paniculiforme ou corimbiforme, terminal ou raramente axial, às vezes capítulos solitários em pedúnculos longos ou raramente sésseis; invólucros cilíndricos ou hemisféricos. Capítulos radiados, discoides, raramente disciformes, heterógamos ou homógamos; brácteas involucrais similares em 1-7 séries, geralmente as mais internas menores, paleáceas; receptáculo geralmente com páleas, às vezes reflexas ou patentes. Flores do raio 5-13(-21+), raramente 1 ou 2, pistiladas, férteis, estéreis ou neutras, corolas às vezes sem tubo, limbo com ápice 3-lobado, às vezes 2-lobado; flores do disco bissexuais ou funcionalmente estaminadas, raramente funcionalmente pistiladas, corola actinomorfa, raramente zigomorfa, campanulada ou urceolada, gradual ou abruptamente expandida acima do tubo; estames 5, raramente 4(-3), filetes glabros, raramente papilosos, anteras conatas ou livres, apêndices do conectivo geralmente ovais; ramos do estilete geralmente com 1 tufo apical de papilas. Cipselas do raio levemente trigonais e compressas, lisas ou estriadas, aladas ou sem alas; cipselas do disco geralmente compressas, biconvexas ou raramente levemente quadrangulares, estreita a largamente obovais ou levemente orbiculares, cilíndricas, prismáticas, estriadas ou não, enegrecidas; pápus de aristas (Figuras 17N-O) persistentes e com escamas, às vezes reduzido ou caduco, ou raramente sem pápus.

No Brasil, ocorrem 38 gêneros e cerca de 228 espécies, sendo cerca de 122 endêmicas. Dentre os gêneros com registros para o Brasil, 10 apresentam apenas espécies naturalizadas (Blainvillea Cass., Calyptocarpus Less., Eleutheranthera Poit. ex Bosc, Lagascea Cav., Parthenium L., Synedrella Gaertn., Synedrellopsis Hieron. \& Kuntze ex Kuntze, Tithonia Desf. ex Juss., Xanthium L. e Zinnia L.). Os gêneros Echinacea Moench, Helianthus L., Montanoa Cerv., Perymenium Schrad., Rudbeckia L. e Sanvitalia Lam. são conhecidos apenas por espécies cultivadas no país. Os gêneros Borrichia Adans., Sclerocarpus Jacq. e Oblivia Strother são conhecidos no Brasil por poucos registros de herbário de forma que ainda restam dúvidas quanto à origem. A proposta de Robinson (1992) de sinonimizar Aspilia Thouars em Wedelia Jacq. é controversa, já que ainda são necessários estudos filogenéticos para esclarecer o status das espécies brasileiras; por isso, esses gêneros foram considerados distintos, como vários autores têm sugerido, a exemplo de Santos (2001), Silva e Santos 
(2010), Hind (2011) e Flora do Brasil 2020 (em construção). Representantes de Heliantheae estão destacados nas Figuras 19D-H e 21A-H.

\section{Chave de identificação para os gêneros de Heliantheae no Brasil}

1. Planta com 2 tipos de capítulo: capítulos apenas com flores pistiladas e capítulos apenas com flores funcionalmente estaminadas............................. 2 1'. Planta com um único tipo de capítulo (Figura 17K) ..................................... 3

2. Brácteas involucrais dos capítulos funcionalmente estaminados conatas; capítulos pistilados com 1 flor; cipselas involucradas, ápice geralmente com projeções espinescentes (Figura 17J) Ambrosia 2'. Brácteas involucrais dos capítulos funcionalmente estaminados livres; capítulos pistilados com 2 flores; cipselas não involucradas, coberta por cerdas uncinadas (Figura 20H) Xanthium

3. Flores do raio com filamentos marginais ligados às páleas de 2 flores do disco (Figura 20C) Parthenium 3'. Flores do raio livres das páleas e flores do disco

4. Capítulos disciformes; corola geralmente com ductos resiníferos levemente avermelhados ao longo das nervuras

4'. Capítulos discoides, radiados ou raramente disciformes; corola com ductos resiníferos não avermelhados ao longo das nervuras 6

5. Capítulos com 1 flor pistilada, invólucro epaleáceo; lobos das flores do disco com tricomas longos e rígidos (Figura 20D); cipselas dispersadas com invólucro (cipselas involucradas) Riencourtia 5'. Capítulos com mais de 2 flores pistiladas; lobos da corola sem tricomas longos; cipselas dispersadas sem invólucro. Clibadium

6. Capitulescência de capítulos agrupados (Figura 20A); capítulos quase sempre unifloros (Figura 20B); brácteas involucrais unidas na base, formando um tubo Lagascea 6'. Capitulescência de capítulos não agrupados; capítulos nunca unifloros; brácteas involucrais livres 7 
7. Ápice das brácteas involucrais com faixa azul-escura ou enegrecida; corola da flor do raio fundida à cipsela (Figura 20I) Zinnia 7'. Ápice das brácteas involucrais sem faixa azul-escura ou enegrecida; corola da flor do raio não fundida à cipsela

8. Receptáculo convexo a cônico, tornando-se fortemente cônico a colunar na maturidade. 9

8'. Receptáculo plano ou convexo, não aumentando na maturidade ... 13

9. Arbustos eretos a escandentes; lâmina foliar coriácea, capitulescências corimbiformes Salmea

9'. Ervas eretas; lâmina foliar membranácea ou cartácea, capítulos solitários ou em capitulescência formando cimeira laxa... 10

10. Folhas opostas; flores do raio, quando presentes, pistiladas; cipselas ciliadas, pápus 2-aristado, com 2 escamas ou, raramente, com poucas cerdas macias

10'. Folhas alternas; flores do raio neutras; cipselas sem cílios, sem pápus ou com pápus diminuto, coroniforme ou de 2-4 escamas 12

11. Folhas sésseis ou subsésseis; cipselas com margem corticosa conspícua, pápus de aristas delicadas ou sem pápus Spilanthes 11'. Folhas com pecíolo conspícuo; cipselas sem margem corticosa ou, às vezes, com margem corticosa inconspícua, pápus de aristas robustas, levemente espessas na base (Figura 17I). Acmella

12. Páleas com ápice rígido, pontiagudo ou arredondado Echinacea 12’. Páleas sem ápice rígido Rudbeckia

13. Corolas das flores do raio sem tubo. 14

13'. Corolas das flores do raio, quando presentes, com tubo. 16

14. Arbustos decumbentes ou eretos; pápus coroniforme Borrichia 14'. Ervas eretas ou prostadas ou arbustos escandentes, raramente arbustos eretos; pápus aristado ou ausente 
15. Corolas das flores do raio com lâminas planas; cipselas das flores do raio com tricomas uncinados Sanvitalia 15'. Corolas das flores do raio com lâminas involutas; cipselas das flores do raio com tricomas, quando presentes, de outros tipos Oblivia

16. Brácteas involucrais em 1 série. 17

16’. Brácteas involucrais em 2 ou mais séries (1-2 em Melanthera). 20

17. Páleas envolvendo completamente as flores; cipselas dispersadas com as páleas do receptáculo enrijecidas Sclerocarpus 17’. Páleas conduplicadas ou ausentes; cipselas dispersadas sem as páleas do receptáculo. 18

18. Invólucro com 2 brácteas involucrais; cipselas com alas laceradas Synedrellopsis 18’. Invólucro com 3 ou mais brácteas involucrais; cipselas sem alas 19

19. Invólucro com cerca de 5 brácteas involucrais semelhantes entre si; cipselas maduras com margem rugosa, com pápus coroniforme

Eleutheranthera

19'. Invólucro de 3-(4) brácteas involucrais, uma grande e arredondada, foliácea, 2 menores, escariosas (Figura 15P); cipselas maduras com margem lisa, sem pápus

Delilia

20. Receptáculo com páleas filiformes; flores do raio geralmente lineares (Figuras 15L-M). Eclipta

20'. Receptáculo com páleas de outras formas; flores do raio de outros formatos. 21

21. Cipselas sem pápus, com pápus coroniforme inconspícuo ou com pápus de cerdas 22 21'. Cipselas com pápus coroniforme conspícuo ou de aristas ou escamas .

22. Cipselas maduras com superfície carnosa Tilesia

22'. Cipselas maduras com superfície seca 23 
23. Páleas do receptáculo com ápice alargado, espinescente; flores do raio de cor diferente das flores do disco; cipselas obovoides compressas, 2-gonais, presas às páleas do receptáculo, sem pápus Montanoa 23'. Páleas do receptáculo com ápice acuminado; todas as flores da mesma cor; cipselas prismáticas, 3-4-gonais, livres das páleas do receptáculo, pápus de cerdas decíduas

Melanthera

24. Cipselas com constrição na parte central, próxima ao ápice, formando um rostro curto ou, às vezes, inconspícuo, no qual estão inseridos os elementos do pápus (estrutura coroniforme ou de aristas) ........................ 25 24'. Cipselas sem constrição próxima ao ápice, sem rostro ......................... 30

25. Flores do raio neutras ou estéreis .............................................................. 26

25'. Flores do raio pistiladas ............................................................................ 27

26. Brácteas involucrais internas com estrias enegrecidas; corola das flores do disco com bainha de fibras ao longo das nervuras; cipselas clavadas com base atenuada, sem elaiossomos

Elaphandra

26'. Brácteas involucrais internas sem estrias enegrecidas; corola das flores do disco sem bainha de fibras ao longo das nervuras; cipselas cilíndricas, obovoides ou elipsoides, sem base atenuada, com elaiossomos Aspilia

27. Flores do raio inconspícuas; brácteas involucrais com estrias verdes (Figura 19H); páleas do receptáculo com ápice eroso truncado ... Blainvillea 27'. Flores do raio conspícuas; brácteas involucrais sem estrias verdes; páleas do receptáculo com ápice de outros tipos 28

28. Pápus de aristas decíduas Perymenium 28’. Pápus coroniforme persistente 29

29. Ervas geralmente prostradas; capítulos solitários; cipselas conspicuamente tuberculadas, rostro e pápus às vezes recobertos por um colar cortíceo contínuo com o corpo da cipsela (Figura 20E)

Sphagneticola

29'. Ervas geralmente eretas ou arbustos; capítulos raramente solitários; cipselas lisas ou apenas ligeiramente tuberculadas (Figura 20G); pápus não recoberto na maturidade. Wedelia 
30. Planta com ramos hirsutos; embrião proeminente no centro da cipsela e borda plana ao redor Simsia

30'. Plantas sem o conjunto de caracteres 31

31. Cipselas aladas (às vezes, somente as do raio) 32

31'. Cipselas sem alas. 34

32. Cipselas do raio com alas de margem lacerada (Figura 20F) e cipselas do disco sem alas Synedrella

32'. Cipselas do raio e do disco com alas de margem não lacerada 33

33. Brácteas involucrais da série externa patentes, semelhantes às folhas dos ramos; pápus de aristas com fitomelanina Dimerostemma 33'. Brácteas involucrais da série externa apressas ou reflexas; pápus de aristas sem fitomelanina Verbesina

34. Brácteas involucrais da série externa patentes, semelhantes às folhas dos ramos; pápus de aristas com fitomelanina Dimerostemma 34'. Brácteas involucrais da série externa apressas ou reflexas, escariosas ... 35

35. Flores do raio neutras 36

35'. Flores do raio pistiladas 38

36. Cipselas glabras ou pubescentes, sem pápus ou com pápus 2-aristado, decíduo, raramente com escamas intermediárias Helianthus 36'. Cipselas pilosas, pápus coroniforme ou 2-aristado persistente, geralmente com escamas intermediárias 37

37. Pedúnculo fistuloso e inflado abaixo do capítulo. Tithonia 37'. Pedúnculo cheio e não inflado abaixo do capítulo Aldama

38. Cipselas do disco obcônicas ou obpiramidais, pápus coroniforme de aristas muito curtas Baltimora 38'. Cipselas do disco compressas; pápus de aristas conspícuas

Calyptocarpus 


\section{Literatura recomendada}

ALVES, M.; ROQUE N. First record of Sclerocarpus africanus Jacq. (Asteraceae, Heliantheae) for South America. Check List, Porto Alegre, v. 12, n. 6, $2016 \mathrm{a}$.

ALVES, M.; ROQUE N. Flora da Bahia: Asteraceae - Tribo Heliantheae.

Sitientibus série Ciências Biológicas, Feira de Santana, v. 16, p. 1- 63, $2016 \mathrm{~b}$.

ARRAIGADA, J. E. Revision of the genus Clibadium (Asteraceae,

Heliantheae). Brittonia, Bronx, v. 55, p. 245-301, 2003.

BALDWIN, B. G. Heliantheae alliance FUNK, V. A. et al. (Ed.). Systematics, Evolution and Biogeography of Compositae. Vienna: IAPT, 2009.

p. 689-711.

BALDWIN, B. G.; WESSA, B. L; PANERO, J. L. Nuclear rDNA evidence for major lineages of helenioid Heliantheae (Compositae). Systematic Botany, Kent, v. 27, n. 1, p. 161-198, 2002.

BINNS, S. E.; BAUM B. R.; ARNASON J. T. A taxonomic revision of Echinacea (Asteraceae: Heliantheae). Systematic Botany, Kent, v. 27, n. 3, p. 610-632, 2002.

BOLICK, M. R. Systematics of Salmea DC. (Compositae: Heliantheae). Systematic Botany, Kent, v. 16, n. 3, p. 462-477, 1991.

BRINGEL JR., J. B. A. Contribuição ao estudo de Heliantheae (Asteraceae): revisão taxonômica e filogenia de Riencourtia Cass. 2015. 159 f. Tese (Doutorado em Botânica) - Universidade de Brasília, Brasília, DF, 2014.

CLEVINGER J. A.; PANERO J. L. Phylogenetic analysis of Silphium and subtribe Engelmanniinae (Asteraceae: Heliantheae) based on ITS and ETS sequence data. American Journal of Botany, Saint Louis, v. 87, p. 565-572, 2000 .

DELPRETE, P. G. Systematic study of the genus Delilia (Asteraceae, Heliantheae). Plant Systematics and Evolution, New York, v. 194, n. 1, p. 111-122, 1995. 
HIND, D. J. N. An annotated preliminary checklist of the Compositae of Bolivia (Version 2). 2011. Disponível em: < http://www.kew.org/science/tropamerica/ boliviacompositae/>. Acesso em: 12 maio 2017.

JANSEN, R. K. Systematics of Spilanthes (Compositae: Heliantheae). Systematic Botany, Kent, v. 6, n. 3, p. 231-157, 1981.

JANSEN, R. K. The systematics of Acmella (Asteraceae-Heliantheae). Systematic Botany Monographs, Ann Arbor, v. 8, p. 1-115, 1985.

KARIS, P. O. The Heliantheae sensu lato (Asteraceae), clades and classification. Plant Systematics and Evolution, New York, v. 188, n. 3/4 188, p. 139-195, 1993.

KARIS, P. O.; RYDING, O. Tribe Heliantheae. In: BREMER, K. (Ed). Asteraceaecladistics and classification. Portland: Timber Press.1994. p. 559-624.

LÖVE, D.; DANSEREAU, P. Biosystematic studies on Xanthium: taxonomic appraisal and ecological status. Canadian Journal of Botany, Ottawa, v. 37, n. 2, p. 173-208, 1959.

MAGENTA, M. A. G. Viguiera Kunth (Asteraceae, Heliantheae) na América do Sul e Sistemática das Espécies do Brasil. 2006. 399 f. Tese (Doutorado em Botânica) Instituto de Biociências Universidade de São Paulo, São Paulo, 2006.

MAGENTA, M. A. G.; PIRANI, J. R. Novidades taxonômicas em Aldama (Asteraceae-Heliantheae). Rodriguésia, Rio de Janeiro, v. 65, n. 1, p. 175-192, 2014.

MONDIN, C. A. Levantamento da Tribo Heliantheae Cass. (Asteraceae), sensu stricto, no Rio Grande do Sul, Brasil. 2004. 353 f. Tese (Doutorado em em Botânica) - Universidade Federal do Rio Grande do Sul, Porto Alegre, 2004.

MORAES, M. D.; SEMIR J. A revision of Brazilian Dimerostemma (Asteraceae, Heliantheae, Ecliptinae), with a new species and taxonomic adjustments. Brittonia, Bronx, v. 61, n. 4, p. 341-365, 2009.

ORCHARD, A. E.; CROSS, E. W. A revision of the Australian species of Eclipta (Asteraceae: Ecliptinae), with discussion of extra-Australian taxa. Nuytsia, South Perth, v. 23, n. 1, p. 43-62, 2013. 
PANERO, J. L. Tribe Helenieae Cass. In: KUBITZKI, K.; JEFFREY, C. (Ed.). The Families and Genera of Vascular Plant: v. VIII: Flowering Plants Eudicots: Asterales. Berlin: Springer-Verlag, 2007. p. 400-406.

PANERO, J. L. et al. Molecular phylogenetic studies of members of tribes Helenieae, Heliantheae and Eupatorieae (Asteraceae). 2. Tribal/ generic relationships. In: OSBORN J. M. (Ed.). Botany 2001, Abstracts, part 3. Systematics. Saint Louis: Botanical Society of America, 2001.

PANERO, J. L., JANSEN, R. K.; LEVINGER, J. A. C. Phylogenetic relationships of the subtribe Ecliptinae (Asteraceae - Heliantheae) based on chloroplast DNA restriction site data. American Journal of Botany, Saint Louis, v. 86, p. 413-427, 1999.

PANERO, J. L.; FUNK, V. A. Toward a phylogenetic subfamilial classification for the Compositae (Asteraceae). Proceedings of the Biological Society of Washington, Washington, v. 115, n. 4, p. 909-922, 2002.

PARKS, J. C. A revision of North American and Caribbean Melanthera (Compositae). Rhodora, Cambridge, v. 75, n. 802, p. 169-210, 1973.

PAYNE, W. W. A re-evaluation of the genus Ambrosia (Compositae). Journal of the Arnold Arboretu, Cambridge, v. 45, p. 401-438, 1964.

PRUSKI, J. F. Compositae of the Guayana Highland-XI. Tuberculocarpus gen. nov. and some other Ecliptinae (Heliantheae). Novon, Saint Louisv. 6, n. 4, p. 404-418, 1996.

ROBINSON, H. New combinations in Elaphandra Strother (EcliptinaeHeliantheae-Asteraceae). Phytologia, Huntsville, v. 72, p. 144-151, 1992. ROBINSON, H. A revision of the tribal and subtribal limits of the Heliantheae (Asteraceae). Washington : Smithsonian Institution Press,1981. (Smithsonian Contributions to Botany, v. 51).

SANTOS, J. U. 0 gênero Aspilia Thouars no Brasil. Belém: Funtec, 2001.

SEMPLE, J. C. A Revision of the Genus Borrichia Adans. (Compositae). Annals of the Missouri Botanical Garden, v. 65, n. 2, p. 681-693, 1978.

SILVA, G. A. R.; SANTOS, J. U. Novos registros de espécies da subtribo Ecliptinae (Heliantheae-Asteraceae) para a Amazônia brasileira. Acta Amazonica, Manaus, v. 40, n. 3, p. 499-508, 2010. 
SHERFF, E. E. The genus Bidens. Field Museum of Natural History, Botanical Series, Chicago, v. 16, p. 1-709, 1937.

SCHILLING, E. E.; PANERO, J. L. A revised classification of subtribe Helianthinae (Asteraceae: Heliantheae) II. Derived Lineages. Botanical Journal of the Linnean Society, London, v. 167, n. 3, p. 311-331, 2011.

SPOONER, D. M. Systematics of Simsia (Compositae-Heliantheae). Systematic Botany Monographs, Ann Arbor, v. 30, p. 1-90, 1990.

STROTHER, J. L. Oblivia, a new genus for Zexmenia mikanioides (Compositae: Heliantheae). Systematic Botany, Kent, v. 14, n. 4, p. 541-543, 1989.

STUESSY, T. F. Revision of the genus Baltimora (Compositae, Heliantheae). Field Museum of Natural History, Botanical Series, Chicago, v. 36, n. 5, 1973.

STUESSY, T. F. Heliantheae - systematic reviewin. In: HEYWOOD, V. H.; HARBORNE, J. B.; TURNER, B. L. (Ed.). The Biology and chemistry of the Compositae. London: Academic Press, 1977. p. 621-671,

STUESSY, T. F. Revision of Lagascea (Compositae, Heliantheae). Chicago: Field Museum of Natural History, 1978. (Fieldiana., Botany v. 38, n. 8).

TORRES, A. M. Revision of Sanvitalia (Compositae-Heliantheae). Brittonia, Bronx, v. 16, n. 4, p. 417-433, 1964.

TORRES, A. M. Revision of Jaegeria (Compositae-Heliantheae). Brittonia, Bronx, v. 20, p. 52-73, 1968.

Turner, B. L. Taxonomic study of the genus Synedrella (AsteraceaeHeliantheae). Phytologia, Huntsville, v. 76, n. 1, p. 39-51, 1994.

TURNER, B. L.; POWELL, A. M. Helenieae - systematic review. In: HARBORNE, J.; TURNER, B. L; HEYWOOD, V. (Ed.). The biology and chemistry of the Compositae. London: Academic Press, 1977. p. 699-737.

URBATSCH, L. E.; BALDWIN B. G.; DONOGHUE M. J. Phylogeny of the Coneflowers and relatives (Heliantheae: Asteraceae). Systematic Botany, Kent, v. 25, n. 3, p. 539-565, 2000. 


\section{TRIBO MILLERIEAE LINDL.}

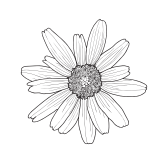

Maria Alves

João Bernardo de A. Bringel Jr.

Mara Angelina Galvão Magenta

A tribo Millerieae foi recentemente restabelecida por Panero e Funk (2002) com base em resultados de análises filogenéticas utilizando dados moleculares de cloroplasto. A nova circunscrição acomodou na tribo os gêneros que pertenciam às subtribos Desmanthodiinae, Espeletiinae, Galinsogiinae, Guardiolinae, Melampodiinae e Milleriinae de Heliantheae sensu Robinson (1981). Panero (2007) fez o primeiro tratamento taxonômico para Millerieae e, segundo o autor, a tribo não possui nenhuma característica morfológica que a defina. Contudo, a maioria das espécies tende a ter folhas opostas, páleas do receptáculo escariosas, cipselas subcilíndricas e pápus, quando presente, paleáceo ou cerdoso.

Millerieae possui, atualmente, 34 gêneros e cerca de 400 espécies encontradas, principalmente na região central do México e norte dos Andes, com algumas espécies em regiões tropicais do Velho Mundo, especialmente na África (PANERO, 2007).

\section{Descrição}

Ervas anuais ou perenes, arbustos ou árvores. Folhas geralmente opostas, às vezes em rosetas basais, pecioladas ou sésseis, por vezes com bases foliares ampliadas ou formando uma cúpula (invaginada) em torno do caule, lâminas foliares lineares a ovadas, às vezes suborbiculares. Capitulescência em cimeiras paniculiformes ou corimbiformes, algumas 
vezes escaposa. Capítulos radiados ou discoides, raramente disciformes, invólucro obcônico ou hemisférico, brácteas involucrais 1-5, raramente mais de 5 séries, às vezes dimórficas, moderada a densamente pubescentes; receptáculo paleáceo, com páleas planas ou naviculares, às vezes cuculadas. Flores do raio pistiladas, raramente neutras, algumas vezes em múltiplas séries, corolas raramente bilabiadas, ápices geralmente conspicuamente trilobados; flores do disco bissexuais ou funcionalmente estaminadas, actinomorfas ou, às vezes, as periféricas zigomorfas com 3 lobos abaxiais mais longos, corola normalmente pubescente e com tricomas glandulares; anteras com apêndices do conectivo lanceolados a ovados; ramos do estilete total ou parcialmente fundidos. Cipselas obcônicas a subcilíndricas, às vezes 4-gonais; pápus paleáceo, barbelado ou de cerdas plumosas, cerdas de comprimento igual ou desigual, às vezes caducas, ou pápus ausente.

No Brasil, a tribo Millerieae está representada por 11 gêneros e cerca de 38 espécies. O gênero Ichthyothere Mart. destaca-se pela maior quantidade de espécies (19), sendo que 12 são exclusivas do país (BFG, 2015). Guizotia Cass. está representado por apenas uma espécie cultivada, G. abyssinica (L.f.) Cass.

\section{Chave de identificação para os gêneros de Millerieae no Brasil}

1. Cipselas com pápus plumoso ou paleáceo ………………………………..... 2

1'. Cipselas sem pápus ........................................................................................... 4

2. Pápus de páleas ciliadas, fimbriadas ou laciniadas (Figura 20J)

Galinsoga

2'. Pápus plumoso

3. Capítulos em cimeiras paniculiformes congestas; brácteas involucrais em 3-4 séries Schistocarpha

3'. Capítulos solitários ou aos pares; brácteas involucrais em 2 séries Tridax

4. Cipselas com cerdas uncinadas Acanthospermum 4'. Cipselas desprovidas de cerdas uncinadas 5 
5. Capítulos disciformes Ichthyothere

5'. Capítulos radiados 6

6. Brácteas involucrais da série externa linear-espatuladas; brácteas involucrais e páleas com glândulas Sigesbeckia 6'. Brácteas involucrais da série externa lanceoladas, oblongas, ovadas ou obovadas; brácteas involucrais e páleas sem glândulas 7

7. Brácteas involucrais em 1 série, possuindo expansão hialina que envolve a base das flores do raio Jaegeria 7'. Brácteas involucrais em 2 ou mais séries, expansão hialina na base ausente 8

8. Brácteas involucrais e páleas com estrias avermelhadas; flores do disco bissexuais. Guizotia 8'. Brácteas involucrais e páleas sem estrias avermelhadas; flores do disco funcionalmente estaminadas

9. Brácteas involucrais externas foliáceas, expandidas; as internas, menores, côncavas; flores do raio 20-100. Smallanthus 9'. Brácteas involucrais das 2 ou mais séries similares na forma e tamanho; flores do raio 3-15. 10

10. Corola da flor do raio conectada à região lateral do ápice da cipsela (Figura 20K); cada flor do raio firmemente envolvida por uma bráctea involucral interna vascularizada Melampodium 10'. Corola da flor do raio conectada à região central do ápice da cipsela; cada flor do raio subentendida por uma bráctea involucral interna, mas não envolvida por ela Unxia

\section{Literatura recomendada}

BRAZIL FLORA GROUP - BFG. Growing knowledge: an overview of seed plant diversity in Brazil. Rodriguésia, Rio de Janeiro, v. 66, n. 4, p. 1085-1113, 2015. 
BLAKE, S. F. Revision of the genus Acanthospermum. Contributions from the United States National Herbarium, Washington, v. 20, p. 383-392, 1921.

BAAGOE, J. The genus Guizotia (Compositae): a taxonomic revision. Botanisk Tidsskrift, Kjobenhavn, v. 69, n. 1, p. 1-39, 1974.

BRINGEL JR., J. B. A.; CAVALCANTI. T. B. Heliantheae (Asteraceae) na Bacia do Rio Paranã (Goiás, Tocantins), Brasil. Rodriguésia, Rio de Janeiro, v. 60, n. 3, p. 551-580, 2009.

CANNE, J. M. A revision of the genus Galinsoga (Compositae: Heliantheae). Rhodora, Cambridge, v. 79, p. 319-389, 1977.

FRISBY, S.; HIND, D. J. N. Ichthyothere woodii (Compositae: Heliantheae: Milleriinae), a new species from the cerrados of eastern Santa Cruz, Bolívia. Kew Bulletin, London, v. 68, p. 495-503, 2013.

FRISBY, S.; HIND, D. J. N. Ichthyothere sasakiae, (Compositae: Heliantheae: Milleriinae), a new species from the Amazonian campo rupestre of northern Mato Grosso State, Brazil. Kew Bulletin, London, v. 69, n. 2, p. 1-7, 2014.

GANDARA, A.; ALVES, M.; ROQUE, N. Flora da Bahia: Asteraceae - Tribo Millerieae. Sitientibus, Feira de Santana, v. 16, 2016. Série Ciências Biológicas

GETINET, A.; SHARMA, S. M. Niger. Guizotia abyssinica (L.f.) Cass. Promoting the conservation and use of underutilized and neglected crops 5. Rome: International Plant Genetic Resources Institute,1996.

MAGENTA, M. A. G. As subtribos Ambrosiinae, Galinsoginae e Coreopsidinae (Heliantheae-Asteraceae) no Estado de São Paulo. 1998. 134 f. Dissertação (Mestrado em Botânica) - Instituto de Biociências, Universidade de São Paulo São Paulo, 1998.

MONDIN, C. A. Levantamento da Tribo Heliantheae Cass. (Asteraceae), sensu stricto, no Rio Grande do Sul, Brasil. 2004. 353 f. Tese (Doutorado em Botânica) - Universidade Federal do Rio Grande do Sul, Porto Alegre, 2004. 
PANERO, J. L. Tribe Millerieae Lindl. In: KADEREIT, J. W.; JEFFREY, C. (Ed.). The Families and Genera of Vascular Plant: v. VIII: Flowering Plants Eudicots: Asterales. Berlin: Springer, 2007. p. 477-492

PANERO, J. L.; FUNK, V. A. Toward a phylogenetic subfamilial classification for the Compositae (Asteraceae). Proceedings of the Biological Society of Washington, Washington, v. 115, n. 4, p. 909-922, 2002.

PEREIRA, R. C. A. Revisão Taxonômica do gênero Ichthyothere Mart. (Heliantheae-Asteraceae). 2001. Tese (Doutorado) - Universidade Federal Rural de Pernambuco, Recife, 2001.

POWELL, A. M. Taxonomy of Tridax (Compositae). Brittonia, Bronx, v. 17, n. 1, p. 47-96, 1965.

ROBINSON, B. L. Synopses of the genera Jaegeria and Russelia. Proceedings of the American Academy of Arts and Science, Boston, v. 35, n. 16, p. 315-321, 1990.

ROBINSON, B. L.; GREENMAN, J. M. Revision of the genus Tridax. Contributions from the Gray Herbarium of Havard University, Cambridge, v. 10, p. 3-10, 1896.

ROBINSON, H. Studies in the Heliantheae (Asteraceae). XII. Reestablishment of the genus Smallanthus. Phytologia, Huntsville, v. 39, p. $47-53,1978$.

ROBINSON, H. A revision of the tribal and subtribal limits of the Heliantheae (Asteraceae). Washington :Smithsonian Institution Press, 1981. (Smithsonian Contributions to Botany, v. 51).

STUESSY, T. F. Re-establishment of the genus Unxia (CompositaeHeliantheae). Brittonia, Bronx, v. 21, n. 4, p. 314-321, 1969.

STUESSY, T. F. The genus Acanthospermum (Compositae-HeliantheaeMelampodiinae): Taxonomic changes and generic affinities. Rhodora, Cambridge, v. 72, p. 106-109, 1970.

STUESSY, T. F. Revision of the genus Melampodium (Compositae: Heliantheae). Rhodora, Cambridge, v. 74, p. 1-70, 1972. 
TORRES, A. M. Revision of Jaegeria (Compositae-Heliantheae). Brittonia, Bronx, v. 20, p. 52-73, 1968.

TURNER, B. L. New species and combinations in the genera Sigesbeckia and Trigonospermum (Compositae: Melampodiinae). Brittonia, Bronx, v. 30, n. 1, p. 64-68, 1978.

TURNER, B. L. Update on the genus Jaegeria (Compositae-Heliantheae). Phytologia, Huntsville, v. 55, p. 243-251, 1984.

WELLS, J. R. A taxonomic study of Polymnia. Brittonia, Bronx, v. 17, n. 2, p. 144-159. 1965. 

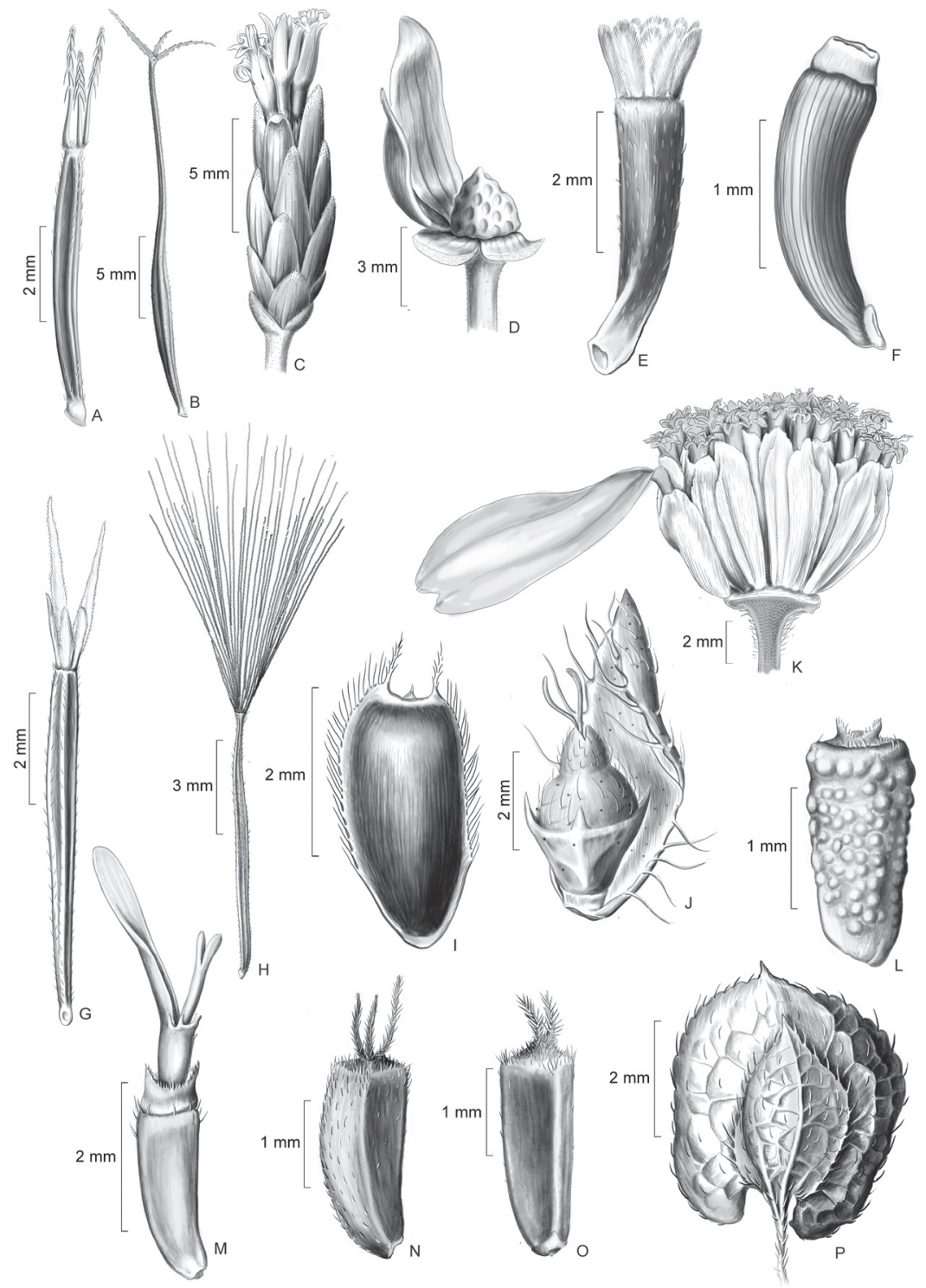

Figura 17. Coreopsideae. A. Cipsela e pápus de Bidens pilosa L.; B. Cipsela e pápus de Cosmos sulphureus Cav. Neurolaeneae. C. Capítulo de Calea morii H. Rob.; D-E. Calea angusta S.F. Blake: D. Receptáculo cônico; E. Cipsela com pápus de páleas livres. F. Cipsela, pápus coroniforme e carpopódio assimétrico de Enydra radicans (Willd.) Lack. Tageteae. G. Cipsela e pápus de Tagetes minuta L.; H. Cipsela e pápus de Porophyllum ruderale (Jacq.) Cass. Heliantheae. I. Cipsela com margem levemente corticosa de Acmella uliginosa (Sw.) Cass.; J. Cipselas involucradas, ápice com projeções espinescentes de Ambrosia artemisiifolia L.; K. Receptáculo com 1-2 páleas envolvendo as respectivas flores de Aspilia subalpestris Baker; L-M. Eclipta prostrata (L.) L.: L. Cipsela tuberculada; M. Flor do raio; N-O. Blainvillea acmella (L.) Philipson: N. Cipsela do raio; O. Cipsela do disco; P. Invólucro de 3-(4) brácteas involucrais, uma grande e arredondada foliácea, 2 menores escariosas de Delilia biflora (L.) Kuntze. 

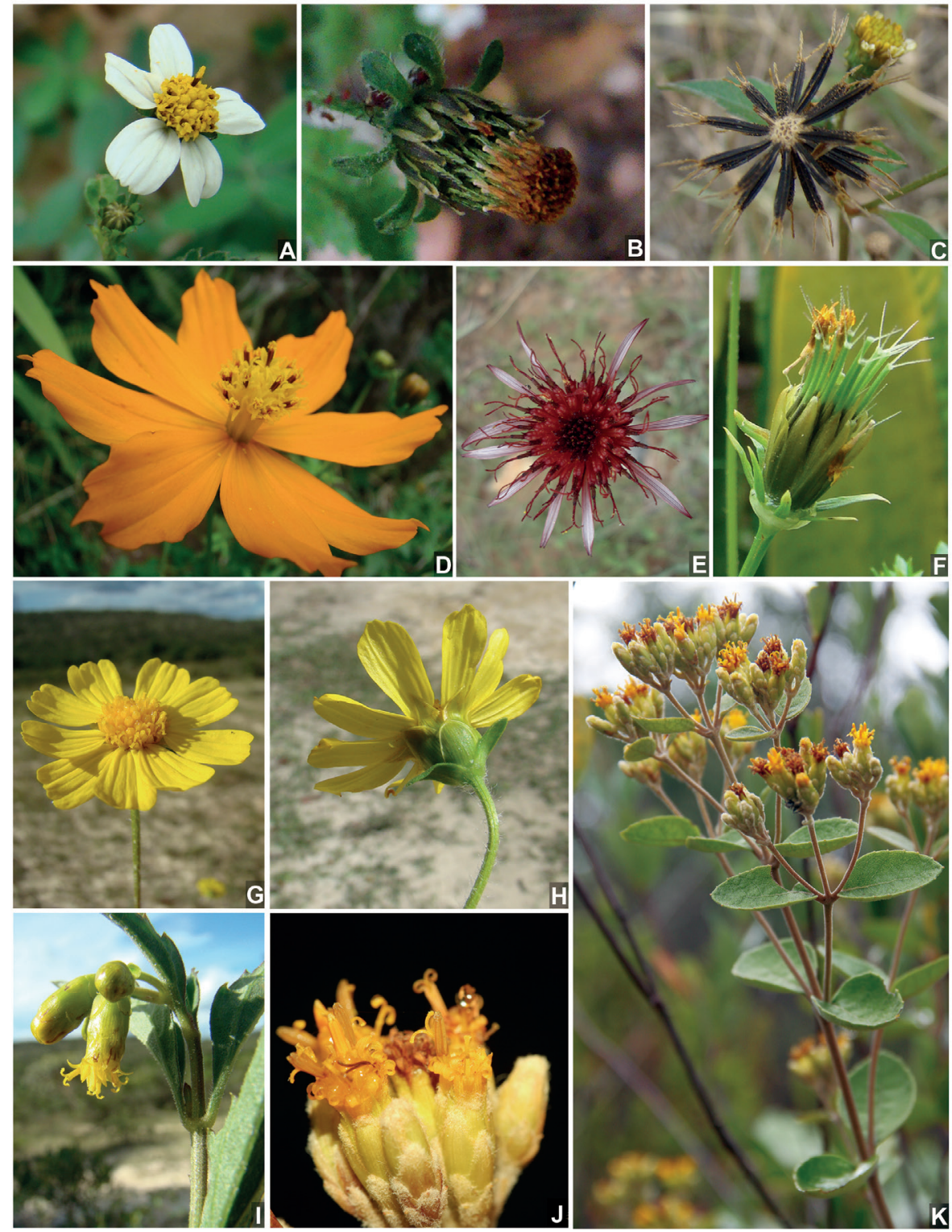

Figura 18. Coreopsideae. A-C. Bidens pilosa L.; D,F. Cosmos sulphureus Cav.; E. Isostigma peucedanifolium (Spreng.) Less. Neurolaeneae. G-H. Calea candolleana (Gardner) Baker; I. Calea harleyi H. Rob.; J-K. Calea morii H. Rob. 

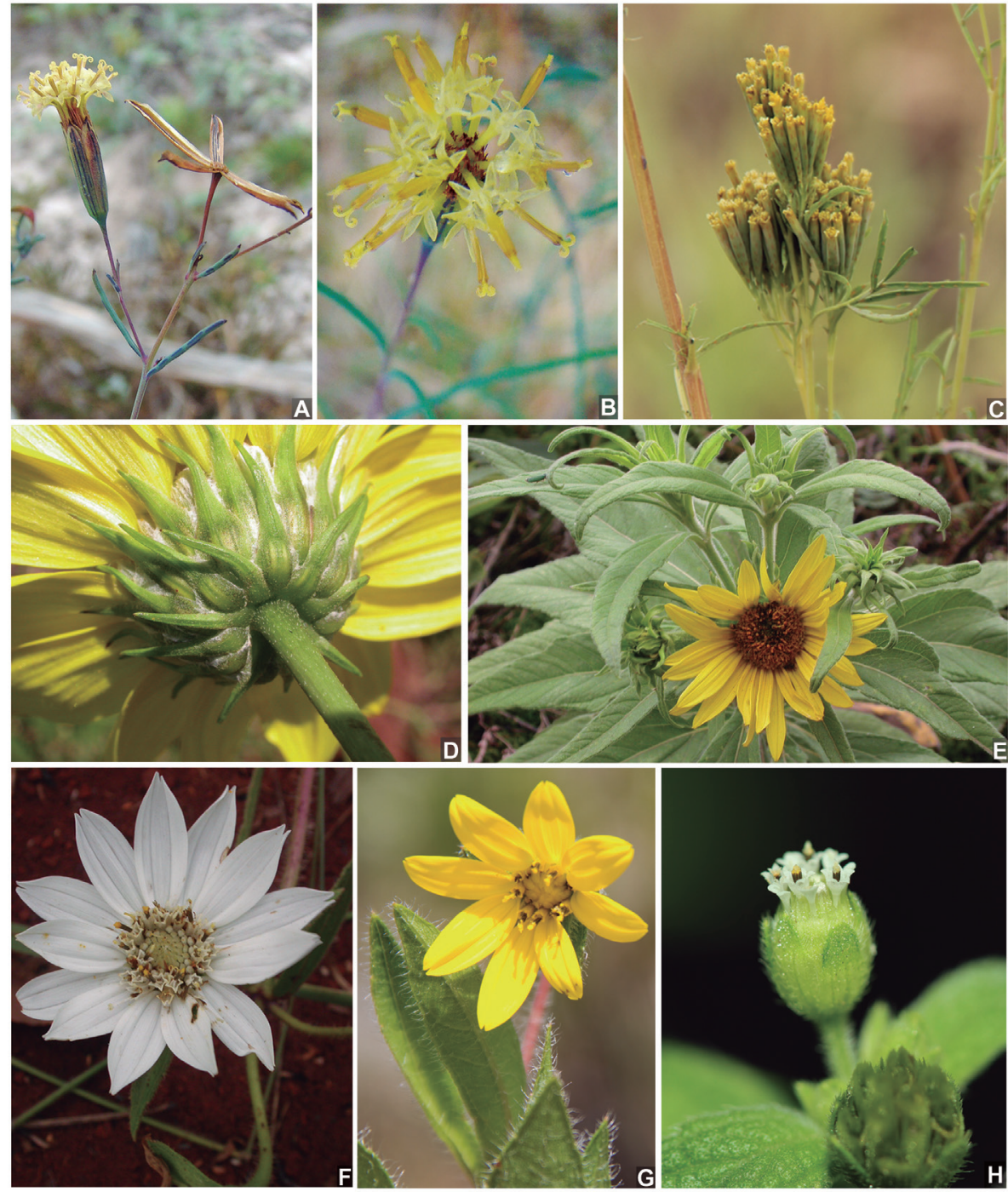

Figura 19. Tageteae. A-B. Porophyllum sp.; C. Tagetes minuta L. Heliantheae. D. Aldama linearifolia (Chodat) E.E. Schill. \& Panero; E. Aldama santacatarinensis (H. Rob. \& A.J. Moore) E.E. Schill. \& Panero; F. Aspilia leucoglossa Malme; G. Aspilia riedelii Baker; H. Blainvillea acmella (L.) Philipson. 


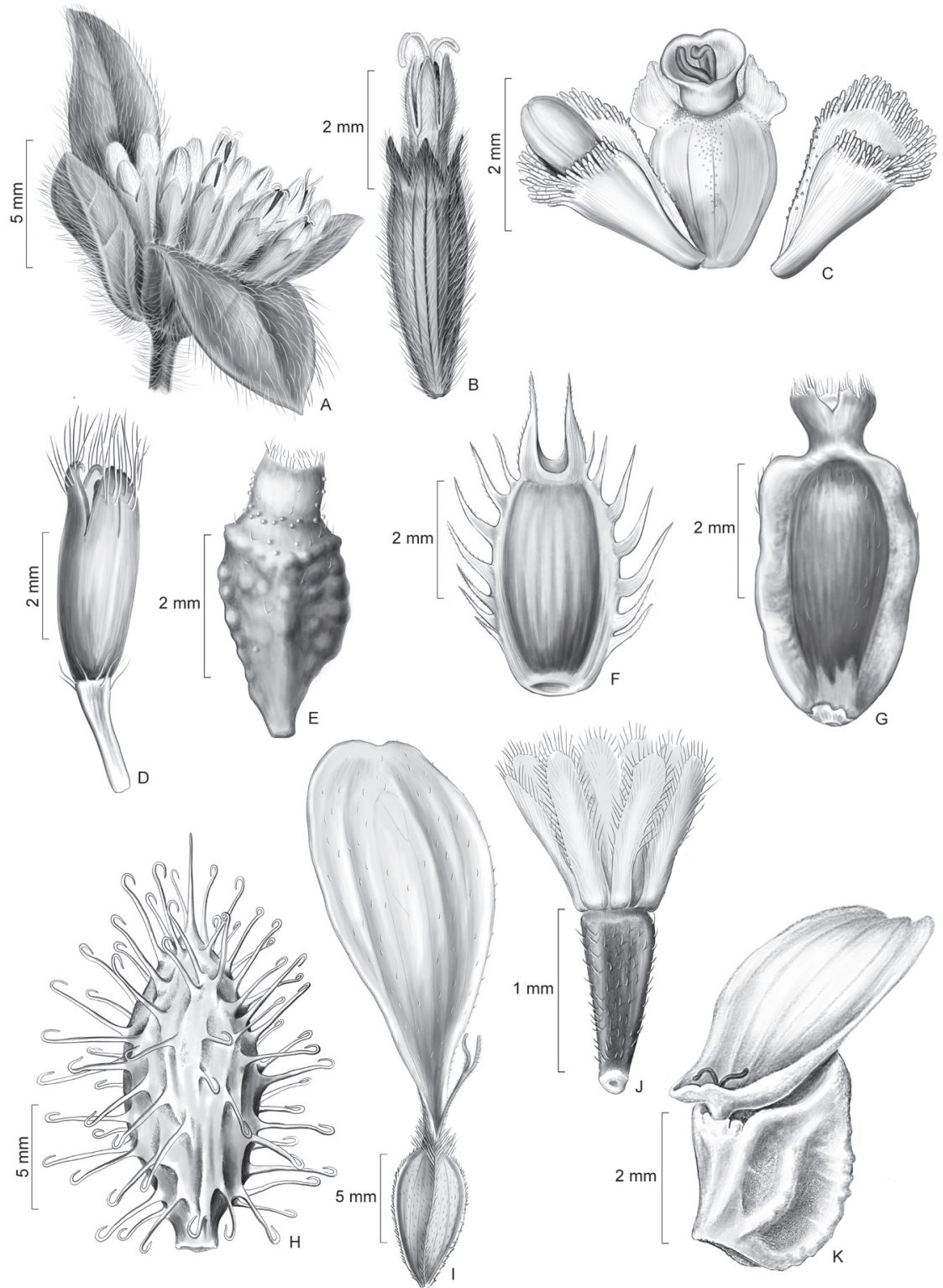

Figura 20. Heliantheae. A-B. Lagascea mollis Cav.: A. Sincefalia ou capítulos de $2^{\text {a }}$ ordem; B. Capítulo com 1 flor e brácteas fundidas; C. Flor do raio com filamentos marginais ligados às páleas de 2 flores do disco de Parthenium hysterophorus L.; D. Lobos das flores masculinas com tricomas longos e rígidos de Riencourtia tenuifolia Gardner; E. Cipsela conspicuamente tuberculada de Sphagneticola trilobata (L.) Pruski; F. Alas da cipsela com margem lacerada de Synedrella nodiflora (L.) Gaertn.; G. Cipsela lisa de Wedelia goyazensis Gardner; H. Cipsela uncinada de Xanthium spinosum L.; I. Corola da flor do raio fundida à cipsela de Zinnia elegans Jacq. Millerieae. J. Pápus paleáceo de Galinsoga parviflora Cav.; K. Corola da flor do raio conectada à região lateral do ápice da cipsela de Melampodium paniculatum Gardner. 

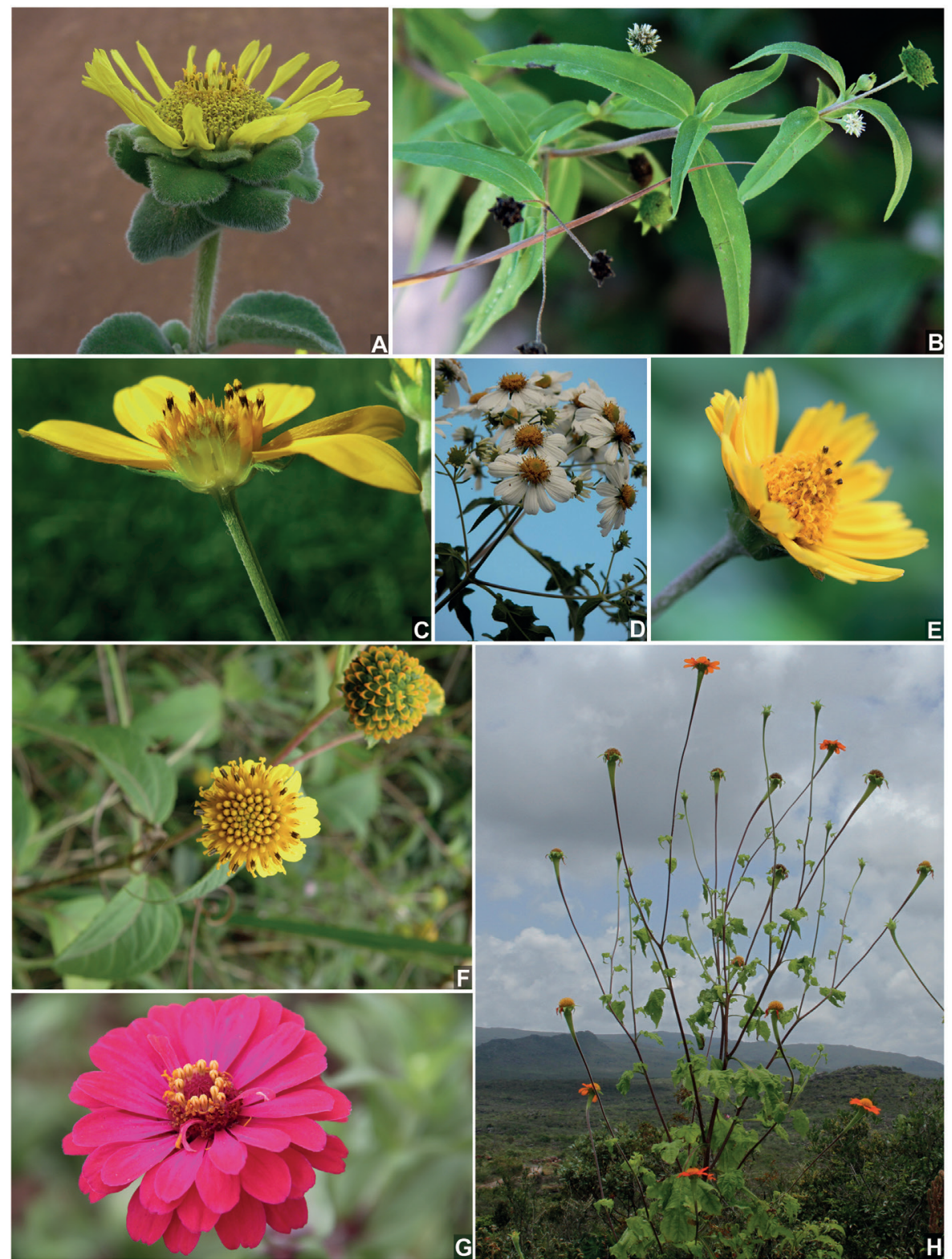

Figura 21. Heliantheae. A. Dimerostemma vestitum (Baker) S.F. Blake; B. Eclipta prostrata (L.) L.; C.

Melanthera latifolia (Gardner) Cabrera; D. Montanoa sp.; E. Sphagneticola trilobata (L.) Pruski; F. Tilesia baccata (L.f.) Pruski; G. Zinnia elegans Jacq.; H. Tithonia rotundifolia (Mill.) S.F. Blake. 


\title{
TRIBO EUPATORIEAE CASS.
}

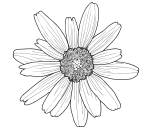 \\ Jimi Naoki Nakajima \\ Silvana da Costa Ferreira \\ Ana Claudia Fernandes \\ Vanessa Lopes Rivera \\ Eric Koiti Okiyama Hattori \\ Aline Silva Quaresma \\ Mara Rejane Ritter \\ Mariana Andrea Grossi
}

A tribo Eupatorieae foi uma das primeiras tribos a serem reconhecidas na classificação de Asteraceae (BREMER, 1994), sendo aceita atualmente como monofilética e pertencente ao clado da Aliança Heliantheae (HIND; ROBINSON, 2007; PANERO; CROZIER, 2016; PANERO; FUNK, 2008). As características mais marcantes dessa tribo são as suas folhas geralmente opostas, capítulos discoides, ramos do estilete com apêndices estéreis alongados, obtusos e coloridos e cipselas com fitomelanina (ROBINSON; SCHILLING; PANERO, 2009).

A tribo foi intensivamente estudada entre as décadas de 1970 e 1990, com base no estudo de microcaracterísticas florais, o que resultou em muitas mudanças taxonômicas (KING; ROBINSON, 1987). Dentre elas, a segregação e reconhecimento de uma centena de gêneros a partir de Eupatorium L. (BREMER, 1994), que ficou circunscrito ao Hemisfério Norte, concentrado na América do Norte, com algumas espécies ocorrendo naturalmente na Ásia e Europa (KING; ROBINSON, 1987).

Entretanto, muitos estudos taxonômicos ou tratamentos sistemáticos realizados com a tribo Eupatorieae no Brasil - por exemplo Matzenbacher (1979), Cabrera e Klein (1989) e Barroso (1991) - não utilizaram essa nova 
classificação e continuaram a adotar o conceito tradicional de Eupatorium L. (sensu BAKER, 1876), dificultando a compreensão dos táxons dessa tribo.

Recentemente, um estudo filogenético baseado em marcadores moleculares foi realizado (RIVERA et al., 2016) com enfoque nas Eupatorieae brasileiras. Os resultados revelaram muitos gêneros e subtribos polifiléticos, indicando que a classificação de Eupatorieae poderá passar por uma nova mudança.

A tribo apresenta diversas espécies na América do Norte e poucas espécies pantropicais ou no Velho Mundo, sendo essencialmente neotropical e concentrada no México e nas Américas Central e do Sul (ROBINSON; SCHILLING; PANERO, 2009). Eupatorieae conta com cerca de 182 gêneros, arranjados em 17 subtribos e cerca de 2.200 espécies (HIND; ROBINSON, 2007; ROBINSON; SCHILLING; PANERO, 2009).

\section{Descrição}

Ervas, arbustos ou lianas, raramente pequenas árvores, ervas aquáticas ou epífitas. Folhas geralmente opostas, frequentemente pecioladas, inteiras, às vezes lobado-pinatissectas ou dissectas, geralmente trinervadas. Capitulescências geralmente corimboso-paniculiformes, às vezes tirsoideo-paniculiformes, espiciformes ou glomeruliformes, raramente capítulos isolados. Capítulos homógamos, discoides, raramente unifloros; invólucro subimbricado a imbricado, brácteas involucrais 1-2-seriadas a multisseriadas, geralmente persistentes, raramente parcial ou totalmente caducas; receptáculo epaleáceo, raramente paleáceo, glabro. Flores bissexuais, corola tubulosa, 5-lobada, raramente 4-lobada, actinomorfa, às vezes flores marginais com corola zigomorfa, alvas, róseas, púrpura ou violeta, nunca amarelas; anteras com apêndice oval-lanceolado a oblongo, plano, raramente truncado, emarginado, ou ausente, base obtusa, ecaudada, às vezes curtamente calcarada, colar cilíndrico, às vezes base alargada; estilete com ramos longo exsertos, filiforme-lineares a oblanceolado-clavados, apêndices estéreis obtusos, mamilosos a longo papilosos, geralmente coloridos, 2 áreas estigmáticas distintas, às vezes glanduloso entre as áreas estigmáticas, estilopódio glabro ou pubescente. Cipselas uniformes, geralmente oblon- 
gas, prismáticas, raramente achatadas, geralmente enegrecidas, 5-costadas, mais raramente 7-10-costadas, glabras ou pubescentes, tricomas duplos; pápus cerdoso, simples, cerdas escábrido-barbeladas, raramente plumoso, paleáceo-aristado, coroniforme ou ausente.

No Brasil, essa tribo é a mais rica em número de gêneros e espécies (88 gêneros e 607 espécies). Muitos gêneros e espécies são endêmicos (40 gêneros e 440 espécies), ocorrendo principalmente nas regiões Sul, Sudeste e Centro-Oeste (BFG, 2015). Representantes de Eupatorieae estão destacados nas Figuras 24 a 27.

\section{Chave de identificação para os gêneros de Eupatorieae no Brasil}

1. Brácteas involucrais fundidas na base, receptáculo epaleáceo, sem tecido esclerificado entre as cicatrizes da cipsela 2

1'. Brácteas involucrais livres desde a base, receptáculo paleáceo ou epaleáceo e com tecido esclerificado entre as cicatrizes da cipsela ............. 4

2. Cipsela com carpopódio simétrico; pápus ausente Gymnocoronis 2'. Cipsela com carpopódio assimétrico; pápus constituído de pequenos bastões com tricomas glandulares no ápice (Figura 22B) 3

3. Cipsela levemente curvada (Figura 22B); pápus geralmente com 3 bastões, raramente 5 Adenostemma

3'. Cipsela não curvada, pápus com 5 bastões. Sciadocephala

4. Capítulos com número igual de flores e brácteas involucrais 5

4'. Capítulos com número diferente de flores e brácteas involucrais. 6

5. Flores e brácteas involucrais em número de 4, subtendidos por 1 bráctea subinvolucral; pápus sempre cerdoso. Mikania 5'. Flores e brácteas involucrais em número de 5, sem bráctea subinvolucral; pápus cerdoso (Figuras 23G-H), paleáceo-aristado, aristado ou coroniforme Stevia 
6. Todas as brácteas involucrais caducas, deixando o receptáculo exposto...

6'. Brácteas involucrais externas persistentes; as internas, às vezes, caducas

7. Receptáculo cônico a colunar; cipselas comprimidas (achatadas), com 2-4 costas marginais, ciliadas, carpopódio assimétrico (lateral na base da cipsela) 8

7'. Receptáculo plano; cipselas prismáticas, geralmente com 5 costas; carpopódio simétrico ou obsoleto 10

8. Pápus de cerdas curtas, desiguais Eupatoriopsis

8’. Pápus de cerdas longas, iguais 9

9. Cipsela com 2 costas marginais densamente setulíferas (Figura 22J), pápus com 2-8 cerdas, rígidas, com ou sem cerdas pequenas adicionais

Eitenia

9'. Cipsela com 3-4 costas esparsamente setulífera; pápus 20-40 cerdas capilares Praxelis

10. Flores periféricas com lobos da corola patentes, zigomorfos; ramos do estilete com base alargada; pápus com 5 cerdas Praxeliopsis 10'. Flores periféricas com lobos da corola eretos, actinomorfos; base do estilete cilíndrica; pápus com muitas cerdas longas ou cerdas curtas, desiguais

11. Plantas recobertas por glândulas estipitadas; folhas lobadas a profundamente dissectas; carpopódio pouco diferenciado; pápus com cerdas curtas, desiguais

Lomatozona

11'. Plantas não recobertas por glândulas estipitadas; folhas não lobadas ou dissectas; carpopódio distinto, curtamente cilíndrico; pápus com cerdas longas iguais ou subiguais Chromolaena

12. Receptáculo cônico a colunar, paleáceo (todas as flores subentendidas por páleas ou brácteas involucrais mais internas) Isocarpha 12'. Receptáculo plano, convexo ou cônico, epaleáceo ou paleáceo (páleas dispersas e não subentendendo as flores) 13 
13. Estilete pubescente abaixo da bifurcação

Stylotrichium

13'. Estilete glabro abaixo da bifurcação (Figura 22K) ou com indumento apenas na base (Figuras 22F,I)

14. Corola com lobos internamente papilosos, mamilosos, ou células com paredes sinuosas alongadas, projetando-se como papilas em ambas as superfícies ................................................................................................ 15

14'. Corola com lobos internamente lisos..................................................... 51

15. Lâmina foliar com venação subparalela; brácteas involucrais e páleas do receptáculo com apêndices apicais cartáceos e sinuosos (Figura 23E).

Scherya

15'. Lâmina foliar com venação diferente; brácteas involucrais sem apêndices apicais; páleas do receptáculo sem ápice cartáceo, ou receptáculo epaleáceo.

16. Pápus ausente, coroniforme, paleáceo-aristado, paleáceo, raramente com mais de 5 elementos ......................................................................... 17

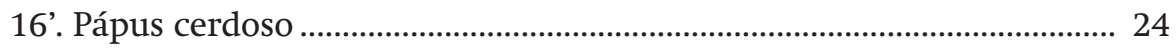

17. Receptáculo paleáceo............................................................................... 18

17'. Receptáculo epaleáceo ......................................................................... 20

18. Brácteas involucrais 30-40; receptáculo cônico............................ Ageratum 18'. Brácteas involucrais 5-25; receptáculo plano ou levemente convexo......

19. Ervas; páleas com ápice densamente fimbriado; base da corola fundida com o ápice da cipsela Teixeiranthus 19'. Arbustos; páleas com ápice inteiro; corola não fundida com a cipsela .. Acritopappus

20. Receptáculo cônico; pápus com 5 paléas aristadas. Ageratum 20'. Receptáculo plano ou convexo; pápus diferente. 21

21. Pápus de 5 escamas curtas Radlkoferotoma

21'. Pápus ausente 22

22. Corola externamente glabra Piqueriella 22'. Corola externamente pilosa 
23. Lâmina foliar repando-denteada a pinatífida; corola infundibuliforme, base glanduloso-estipitada (Figura 22L). Gardnerina 23'. Lâmina foliar inteira ou lobada; corola com tubo constrito, densamente recoberto por tricomas tectores Cavalcantia

24. Ramos do estilete longo-papilosos (Figura 22K); células da superfície mais interna dos lobos da corola com paredes sinuosas alongadas, projetando-se como papilas; colar da antera inconspícuo Fleischmannia 24'. Ramos do estilete papilosos ou mamilosos; lobos da corola com células isodiamétricas; colar da antera geralmente conspícuo e expandido 25

25. Plantas com folhas crassas 26 25’. Plantas com folhas herbáceas, cartáceas ou coriáceas, nunca crassas ...

26. Folhas dispostas em roseta basal; capítulos dispostos no ápice de um escapo floral; receptáculo cônico com cicatrizes pronunciadas

Bishopiella

26'. Folhas dispostas ao longo do caule; capítulos não dispostos em escapo floral; receptáculo plano a levemente convexo com cicatrizes não pronunciadas 27

27. Plantas viscosas, geralmente longo-pecioladas (maior que $1,5 \mathrm{~cm}$ compr.); capítulos pêndulos após a senescência; corola com ductos de resina pareados com as nervuras do tubo; pápus com cerdas curtas (Figura 23A) Morithammus

27'. Plantas não viscosas, geralmente curto-pecioladas (até 1,5 cm compr.); capítulos eretos após a senescência; corola sem ductos de resina; pápus com cerdas longas. 28

28. Lâmina foliar plana, inteira, glabra; brácteas involucrais oblongas ou elípticas; pápus com cerdas creme Litothamnus 28'. Lâmina foliar conduplicada, denteada a denticulada, tomentosa; brácteas involucrais linear-lanceoladas ou oblanceoladas; pápus com cerdas púrpura ou alvas com ápice púrpura Lapidia 
29. Pápus plumoso (Figura 23K) ou ausente; se ausente, corola apresentando densa pubescência nos lobos ........................................................................... 30 29'. Pápus cerdoso, subplumoso ou ausente; se ausente, corola não apresentando densa pubescência nos lobos

30. Caule estriado; corola densamente pubescente nos lobos (Figura 23J); apêndice do conectivo da antera obtuso a levemente retuso.... Trichogonia 30'. Caule liso, raramente estriado; corola com tricomas glandulares nos lobos; apêndice do conectivo da antera bilobado Trichogoniopsis

31. Filotaxia alterno-espiralada, folhas congestas, não diminuindo de tamanho em direção ao ápice da planta 32 31'. Filotaxia oposta ou alterna, folhas laxas, geralmente diminuindo de tamanho em direção ao ápice da planta 39

32. Arbustos a árvores $2-5 \mathrm{~cm}$ alt.; ápice dos ramos e face abaxial da lâmina foliar velutino-ferrugíneo; lâmina foliar largamente ovada $(7-17$ x 2-13 cm), longo-pecioladas (2-6 cm compr.); flores alvo-róseas, aromáticas...... Kaunia 32'. Sem o conjunto das características acima 33

33. Receptáculo paleáceo 34

33'. Receptáculo epaleáceo 36

34. Lâmina foliar linear; capítulos solitários; páleas somente nas flores externas Arrojadocharis 34'. Lâmina foliar lanceolada ou elíptica; capitulescência corimbiforme, raro capítulos solitários; páleas distribuídas em todo o receptáculo 35

35. Invólucro em 2 séries, brácteas involucrais decíduas; ramos do estilete cilíndricos (Figura 22G); pápus ausente ou inconspícuo (0,1 mm compr.) ... Catolesia

35'. Invólucro em 3-5 séries, brácteas involucrais persistentes; ramos de estilete clavados (Figura 22C); pápus presente, raramente ausente

Agrianthus

36. Plantas viscosas; receptáculo plano 37

36'. Plantas não viscosas; receptáculo cônico ou convexo 38 
37. Plantas pubescentes (tricomas glandulares estipitados e eglandulares); cipselas aladas, com presença de calos ao longo das costas (Figura 23F), pápus com cerca de 5 cerdas ou ausente. Semiria

37’. Plantas glabras; cipselas não aladas, calos ausentes, pápus com cerca de 30 cerdas Bahianthus

38. Caule e face abaxial da lâmina foliar cobertos por indumento lanoso; receptáculo piloso (Figura 22P) Lasiolaena 38'. Caule e lâmina foliar glabros ou glabrescentes; receptáculo glabro

Agrianthus

39. Cipselas com a base estipitada (Figura $22 \mathrm{H}$ ) 40

39'. Cipselas com base cilíndrica (Figuras 22D-E, 23A-B)

40. Ervas; anteras com apêndice truncado; base do estilete glabra; pápus subplumoso Platypodanthera 40'. Subarbustos; anteras com apêndice agudo ou obtuso; base do estilete pilosa (Figura 22F); pápus cerdoso 41

41. Receptáculo cônico, com projeções que circundam a inserção da cipsela; corola com lobos tão longos quanto largos; cipsela com as costas creme e fortemente setulíferas

Campuloclinium 41'. Receptáculo plano e foveolado; corola com lobos cerca de 3 vezes mais longos que largos; cipselas e costas concolores, algumas vezes levemente barbeladas Macropodina

42. Estilete com base buliforme, pilosa (Figura 22I) 43

42'. Estilete com base cilíndrica, glabra 44

43. Brácteas involucrais dispostas em 2 séries subiguais em comprimento, receptáculo convexo; anteras com apêndice do conectivo bilobado a emarginado. Diacranthera 43'. Brácteas involucrais dispostas em 3-4 séries desiguais em comprimento, receptáculo cônico; anteras com apêndice do conectivo inteiro, agudo ou obtuso Dasycondylus

44. Receptáculo plano ou levemente convexo 45

44'. Receptáculo subgloboso, cônico ou convexo 48 
45. Ervas com capitulescência subescaposa; brácteas involucrais mais internas com ápice arredondado ou truncado, completamente coberto por denso indumento alvo-tomentoso Gyptis 45'. Subarbustos com capitulescências terminais; brácteas involucrais com ápice agudo não recoberto por indumento alvo-tomentoso. 46

46. Folhas sésseis ou subsésseis; cipselas 7-10-costadas Vittetia 46'. Folhas peciolada; cipselas 5-costadas 47

47. Plantas de restinga; lâmina foliar pinada, brilhante; capítulos 12-14 flores; brácteas involucrais subiguais; cipsela glabra ou com 1-2 cerdas no ápice Prolobus 47'. Plantas de cerrado e caatinga; lâmina foliar trinervada, opaca; capítulos 5-10 flores; brácteas involucrais desiguais; cipsela setulífera e tricomas glandulares

Bejaranoa

48. Receptáculo piloso; pápus com cerdas de ápice obtuso, inflado ......... 49

48’. Receptáculo glabro; pápus com cerdas de ápice agudo ......................... 50

49. Lâmina foliar com base foliar cordada; capitulescência densa, capítulos 100-150 flores; brácteas involucrais com ápice caudado, tomentoso; carpopódio distinto.............................................................................. Urolepis 49'. Lâmina foliar com base truncada; capitulescência laxa, capítulos 5080 flores; brácteas involucrais com ápice agudo, pubescente; carpopódio inconspícuo

Gyptidium

50. Cipselas com tricomas glandulares sésseis (Figura 22E); carpopódio decorrente nas costas da cipsela Barrosoa 50'. Cipselas densamente pubescentes, tricomas glandulares ausentes; carpopódio anuliforme e não decorrente Conocliniopsis

51. Corola com limbo constrito abaixo dos lobos; ramos do estilete longo clavados, espessados; cipselas 5-10 costas 52 51'. Corola com limbo cilíndrico ou infundibuliforme abaixo dos lobos (sem constrição); ramos do estilete não espessados ou espessados somente no ápice; se longo clavado, então achatado; cipselas 4-5 costas 58 
52. Pápus ausente ou de cerdas facilmente caducas 53

52'. Pápus presente e persistente na maturidade do fruto

53. Folhas dispostas ao longo dos ramos; capítulos subtendidos por brácteas da altura dos capítulos, cobertas de tricomas glandulares; flores com corola rósea, externamente pubescente e com tricomas glandulares estipitados ... Planaltoa 53'. Folhas dispostas no ápice dos ramos; capítulos não subtendidos por brácteas da altura dos capítulos; flores com corola branca, externamente glabra

Leptoclinium

54. Pápus de cerdas de tamanhos desiguais ................................................. 55

54'. Pápus de cerdas de mesmo tamanho........................................................ 56

55. Folhas sempre opostas; lâmina foliar ovada; capítulo com 6-8 flores; cipsela 5-costada; pápus com cerdas livres Dissothrix 55'. Folhas opostas ou alternas na mesma planta; lâmina foliar oblanceolada; capítulo com 4 flores; cipsela 7-costada; pápus com cerdas fortemente unidas em um calo no ápice da cipsela.....

Goyazianthus

56. Folhas alternas, densamente espiraladas, lâmina foliar linear.

Pseudobrickellia

56'. Folhas opostas, lâmina foliar ovada

57. Arbustos decumbentes; cipselas 5-costadas Austrobrickellia 57'. Ervas; cipselas 8-10-costadas. Brickellia

58. Base do estilete cilíndrica e glabra; brácteas involucrais internas geralmente caducas 59

58'. Base do estilete cilíndrica pubescente ou alargada glabra ou pubescente; brácteas involucrais internas persistentes 80

59. Capítulos sempre com 5 flores; ramos do estilete com ápice papiloso; pápus com cerdas com ápice espessado 60 59'. Capítulos com 1-300 flores; ramos do estilete geralmente lisos, pelo menos no ápice; pápus com cerdas com ápice nunca espessado 65

60. Capítulos dispostos em panículas de racemos laxas 61 60'. Capítulos dispostos em corimbos terminais densos 62 
61. Lâmina foliar inteira; corola com tubo glanduloso (Figura 23D); ramos do estilete densamente papilosos Raulinoreitzia 61'. Lâmina foliar pinatilobada a pinatissecta; corola com tubo glabro; ramos do estilete aciculado-papilosos (Figura 22A). Acanthostyles

62. Folhas vernicosas, ramos sem tricomas tectores Symphyopappus 62'. Folhas não vernicosas, ramos com tricomas tectores 63

63. Invólucro com 1 série de brácteas externas subuladas maiores que as demais brácteas e frequentemente avermelhadas Grazielia 63'. Invólucro com a série de brácteas externas menores que as mais internas 64

64. Folhas densamente espiraladas; base das cipselas sem carpopódio distinto Disynaphia 64'. Folhas geralmente opostas; base das cipselas com carpopódio distinto Campovassouria

65. Receptáculo glabro; colar da antera até 5 vezes mais comprido do que largo 66

65'. Receptáculo geralmente pubescente; colar da antera 5-10 vezes mais comprido que largo. 78

66. Trepadeiras ou plantas escandentes 67

66'. Pequenas árvores, arbustos, subarbustos ou ervas 68

67. Flores 3-5, corola com lobos oblongos, 2-4 vezes tão longos quanto largos (Figura 23I) e massa densa de tricomas tectores internamente na corola, logo abaixo dos lobos; cipsela com pubescência densa e curta

Steyermarkina

67'. Flores 8-10, corola com lobos oblongo-triangulares, mais de 2 vezes mais longos do que largos, glabros; cipsela esparsamente setulífera

Santosia

68. Invólucro com brácteas subimbricadas (as brácteas são progressivamente maiores em séries sobrepostas) 69 68'. Invólucro com brácteas eximbricadas (as brácteas têm comprimentos semelhantes) 75 
69. Folhas com laticíferos, ou seja, com bolsas secretoras translúcidas nas aréolas das folhas, entre as vênulas; brácteas involucrais internas facilmente decíduas Critonia 69'. Folhas sem laticíferos; todas as brácteas involucrais persistentes ..... 70

70. Ramos e folhas vilosas, com tricomas de base distintamente alargada; receptáculo densamente hirsuto Imeria 70'. Ramos e folhas com tricomas de outros tipos; receptáculo glabro ou paleáceo 71

71. Flores com corola internamente pubescente; apêndice das anteras retuso (Figura 23C) ou bilobado Neocabreria 71'. Flores sem essa combinação de caracteres. 72

72. Corola glabra; carpopódio distintamente cilíndrico; pápus formado por 40-50 cerdas fortemente escabras ou barbeladas na base, que se tornam progressivamente lisas em direção ao ápice Austrocritonia 72'. Corola pilosa ou glandulosa; carpopódio obsoleto ou anuliforme; pápus com cerdas iguais em toda a sua extensão 73

73. Receptáculo com poucas páleas Idiothamnus 73'. Receptáculo glabro 74

74. Invólucro campanulado com 20 brácteas, desiguais, apêndice da antera levemente mais longo que largo, ramos do estilete estreitos, lineares, e levemente a distintamente mamilosos Malmeanthus 74'. Invólucro com 7-16 brácteas subiguais, apêndices mais largos que longos, por vezes muito curtos, ramos do estilete bem largos e se tornando lisos no ápice, não glandulares (Figura 22O) Koanophyllon

75. Capitulescência em panícula tirsoide composta por capítulos sésseis organizados em aglomerados esféricos ou globosos Sphaereupatorium 75'. Capitulescência sem capítulos organizados em aglomerados globosos.. 76 
76. Corola com tubo estreito e limbo estreito campanulado; invólucro eximbricado; apêndice das anteras conspícuo, mais longo do que largo .......

Chacoa

76'. Corola infundibuliforme ou com tubo constrito; invólucro subimbricado; apêndice das anteras encurtado ou vestigial 77

77. Invólucro com 4-8 brácteas involucrais em 1-2 séries desiguais, eretas; ramos do estilete com ápice alargado. Ophryosporus 77’. Invólucro com 7-16 brácteas involucrais em 2-4 séries subiguais, espaçando com a maturidade; ramos do estilete com ápice cilíndrico, obtuso Koanophyllon

78. Receptáculo marcadamente convexo até hemisférico; ramos do estilete filiformes (Figura 22N); carpopódio alongado (Figura 22M) Hebeclinium 78'. Receptáculo ligeiramente convexo; ramos do estilete lineares a ligeiramente clavados; carpopódio anuliforme 79

79. Carpopódio simétrico; receptáculo pouco a densamente pubescente, raramente glabro. Bartlettina 79’. Carpopódio fortemente assimétrico; receptáculo glabro Guayania 80. Base do estilete cilíndrica com tricomas; pápus com cerdas com células apicais geralmente arredondadas 81 80'. Base do estilete alargada com ou sem tricomas; pápus com células apicais agudas 83

81. Cipselas glabras ou somente com tricomas glandulares (Figura 22D) .... Austroeupatorium 81'. Cipselas com numerosos tricomas tectores geminados, às vezes com tricomas glandulares escassos 82

82. Capitulescência corimbiforme; brácteas involucrais 12-15; capítulos 1025 flores; estilete com ramos distintamente papilosos; cipsela levemente estipitada Hatschbachiella 82'. Capitulescência piramidal ou tirsoide; brácteas involucrais 5-12(19); capítulos 3-10(25) flores; estilete com ramos papilosos na base ou lisos quando alargados; cipsela cilíndrica Stomatanthes 
83. Ervas diminutas (até $10 \mathrm{~cm}$ alt.); capítulos com até 10 flores, anteras sem apêndice apical Parapiqueria

83'. Subarbustos eretos ou escandentes; capítulos com mais de 20 flores, anteras com apêndice apical........................................................................ 84

84. Pápus com apenas 1 cerda ou ausente (Figura 23B) ............................ 85

84'. Pápus com 5 a muitas cerdas............................................................... 86

85. Folhas opostas a subopostas, lâmina foliar inteira; brácteas involucrais 20-30; pápus decíduo Alomiella 85'. Folhas alternas, basais opostas, lâmina foliar tripinatífida; brácteas involucrais 15; pápus persistente Monogereion

86. Ramos do estilete densamente papilosos; base do estilete alargada e glabra 87

86'. Ramos do estilete lisos a mamilosos; base do estilete alargada e frequentemente com tricomas. 88

87. Brácteas involucrais 15-35; capítulos 5-40 flores; lobos da corola com glândulas na superfície externa; ramos do estilete filiformes; pápus 20-40 cerdas Ayapana

87’. Brácteas involucrais cerca de 50; capítulos 60-80 flores; lobos da corola com tricomas na superfície externa; ramos do estilete clavados; pápus 5-10 cerdas Gymnocondylus

88. Folhas densamente lanuginosas; brácteas involucrais 30-50; carpopódio cilíndrico Ayapanopsis 88'. Folhas hirsutas ou glandulares, mas nunca densamente lanuginosas; brácteas involucrais 15-30; carpopódio contorcido. Heterocondylus

\section{Literatura recomendada}

AMORIM, V. O.; ROQUE, N. Stylotrichium hortensiae (AsteraceaeEupatorieae): A new species from Chapada Diamantina, Bahia, Brazil. Phytotaxa, Auckland, v. 308, n. 2, p. 283-288, 2017. 
BAKER, J. G. Compositae - Vernoniaceae \& Eupatoriaceae. In: MARTIUS, C. P. von; EICHLER, A. W. (Ed.). Flora Brasiliensis. Muchen: [s.n.], 1876. v. 6, n. 2, p. 1-398.

BARROSO, G. M. Sistemática de Angiospermas do Brasil. Viçosa: UFV, 1991. v. 3. BRAZIL FLORA GROUP- BFG. Growing knowledge: an overview of seed plant diversity in Brazil. Rodriguésia, Rio de Janeiro, v. 66, n. 4, p. 10851113, 2015.

BREMER, K. Asteraceae: cladistics and classification. Portland: Timber Press, 1994.

CABRERA, A. L.; KLEIN, R. M. Compostas. 4: Tribo Eupatorieae. Itajaí: Herbário Barbosa Rodrigues, 1989. (Flora Ilustrada Catarinense).

HIND, D. J. N.; ROBINSON, H. Eupatorieae. In: KUBITZKI, K. (Ed.). The Families and Genera of Vascular Plant: v. VIII: Flowering Plants Eudicots: Asterales. Berlin: Springer-Verlag, 2007. p. 510-572.

KING, R. M.; ROBINSON, H. The genera of the Eupatorieae (Asteraceae). Monographs in Systematic Botany from the Missouri Botanical Garden, v. 22, p. 1-581, 1987.

MATZENBACHER, N. I. Estudo taxonômico de gênero Eupatorium L. (Compositae) no Rio Grande do Sul - Brasil. 1979. 310 f. Dissertação (Mestrado em Botânica) - Universidade Federal do Rio Grande do Sul, Porto Alegre, 1979.

PANERO, J. L.; CROZIER, B. S. Macroevolutionary dynamics in the early diversification of Asteraceae. Molecular Phylogenetics and Evolution, Orlando, v. 99, p. 116-132, 2016.

RIVERA, V. L et al. Origins and recent radiation of Brazilian Eupatorieae (Asteraceae) in the eastern Cerrado and Atlantic Forest. Molecular Phylogenetics and Evolution, Orlando, v. 97, p. 90-100, 2016.

ROBINSON, H.; SCHILLING, E.; PANERO, J. L. Eupatorieae. In: FUNK, V. et al. (Ed.). Systematics, Evolution and Biogeography of Compositae. Vienna: IAPT, 2009. cap. 43. p. 731-744. 


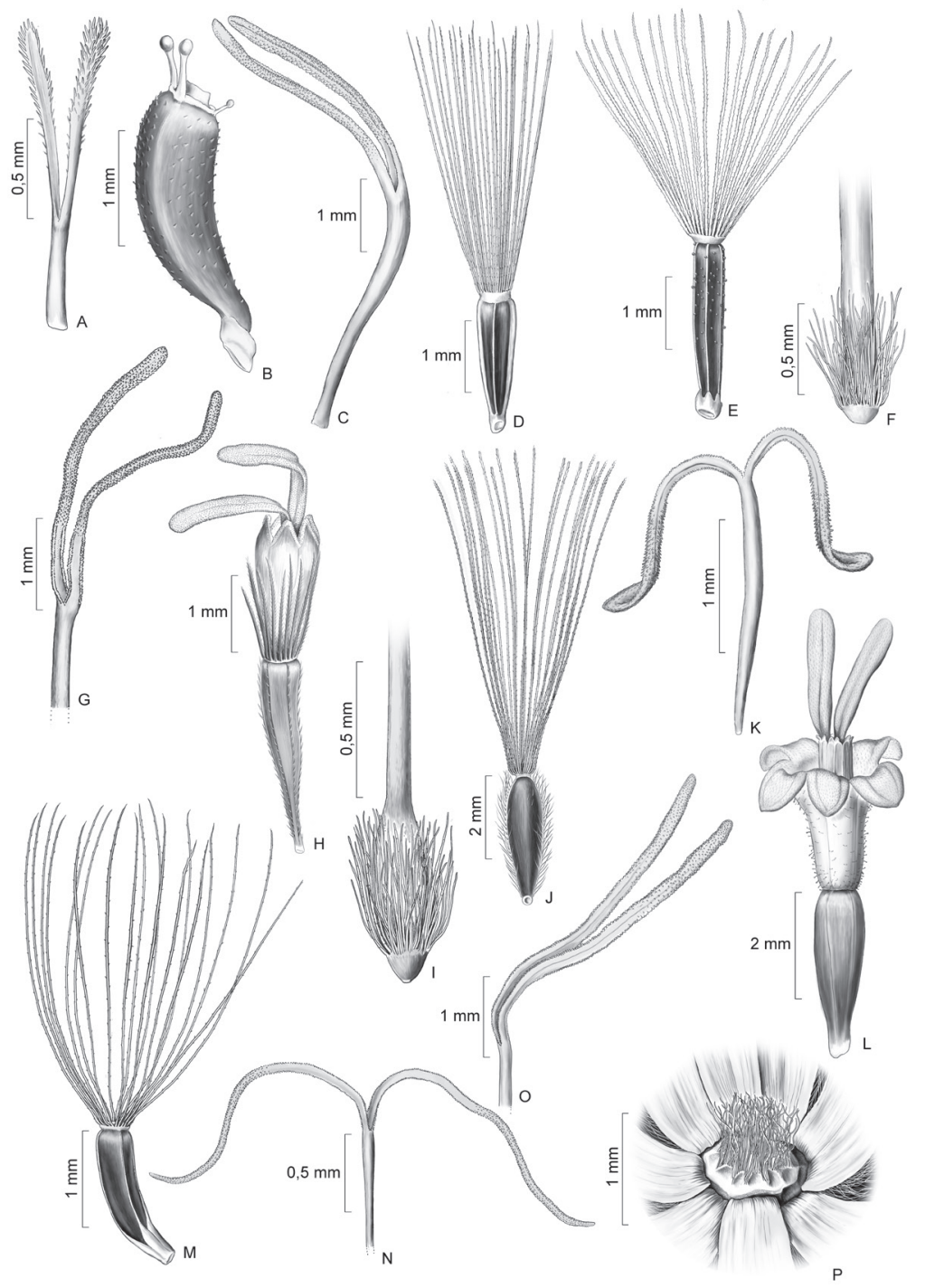

Figura 22. Eupatorieae. A. Ramos de estilete de Acanthostyles buniifolius (Hook. \& Arn.) R.M. King \& H. Rob.; B. Cipsela de Adenostemma brasilianum (Pers.) Cass.; C. Ramos do estilete clavados de Agrianthus empetrifolius Mart. ex DC.; D. Cipsela e pápus de Austroeupatorium silphiifolium (Mart.) R.M. King \& H. Rob.; E. Cipsela e pápus de Barrosoa organensis (Gardner) R.M. King \& H. Rob.; F. Base do estilete pilosa de Campuloclinium hirsutum Gardner; G. Ramos do estilete cilíndrico de Catolesia mentiens D.J.N. Hind; H. Flor de Platypodanthera melissifolia (DC.) M. King \& H. Rob.; I. Estilopódio buliforme e piloso de Diacranthera ulei R.M. King \& H. Rob.; J. Cipsela e pápus de Eitenia polysecta R.M. King \& H. Rob.; K. Ramos do estilete de Fleischmannia remotiflora (DC.) R.M. King. \& H. Rob.; L. Tubo da corola com tricomas glandulares em Gardnerina angustata (Gardner) R.M. King \& H. Rob. M-N. Hebeclinium macrophyllum (L.) DC.: M. Cipsela e pápus com carpopódio decorrente; N. Ramos do estilete filiformes; O. Ramos do estilete de Koanophyllon adamantium (Gardner) R.M. King \& H. Rob.; P. Receptáculo piloso de Lasiolaena blanchetii (Sch. Bip. ex Baker) R.M. King \& H. Rob. 


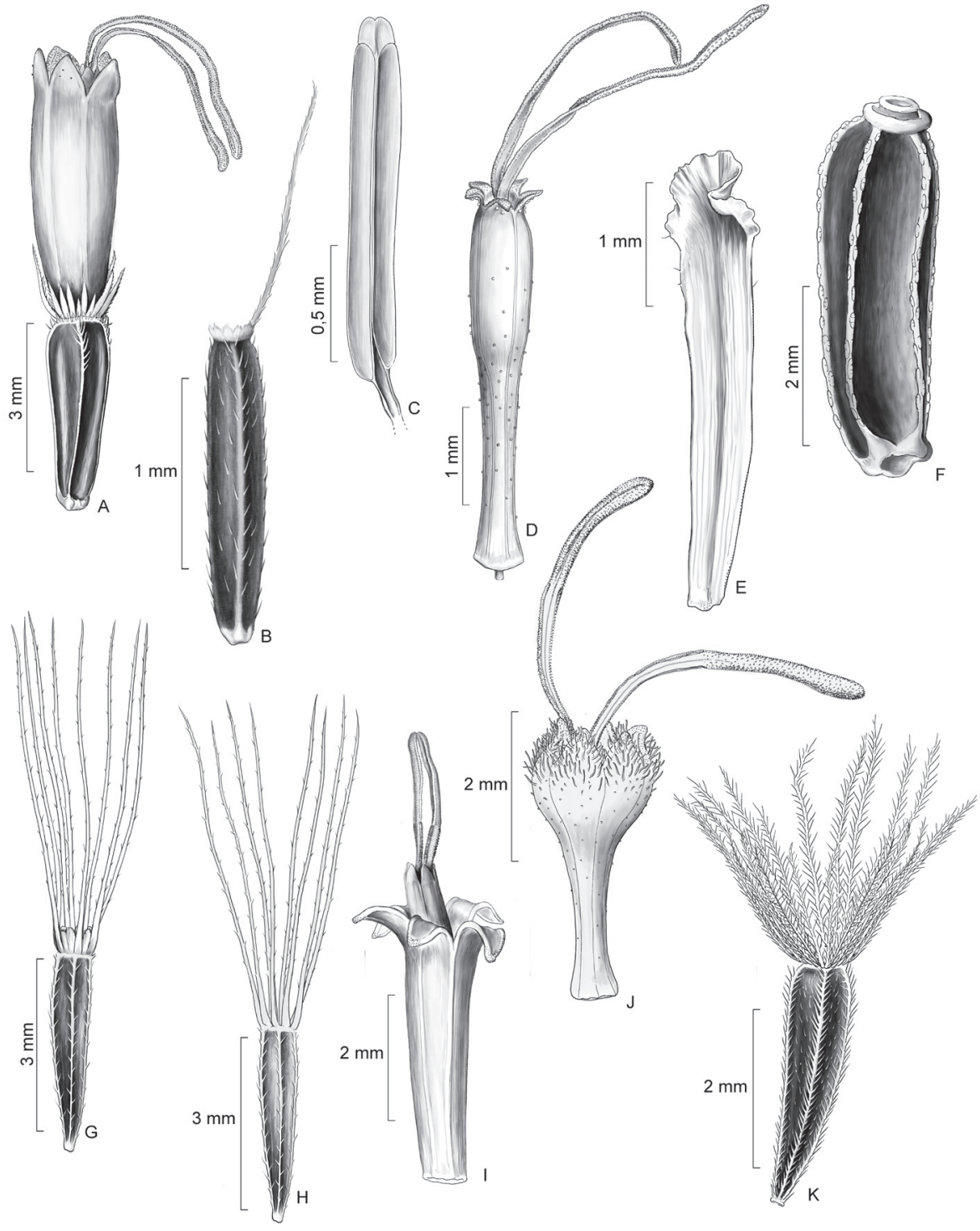

Figura 23. Eupatorieae. A. Flor de Morithamnus crassus R.M. King \& H. Rob.; B. Cipsela e pápus de Monogereion carajensis G.M. Barroso \& R.M. King; C. Apêndice do conectivo retuso de Neocabreria serrulata (DC.) R.M. King. \& H. Rob.; D. Corola e ramos do estilete de Raulinoreitzia crenulata (Spreng.) R.M. King \& H. Rob.; E. Pálea com ápice cartáceo sinuoso de Scherya bahiensis R.M. King \& H. Rob.; F. Cipsela de Semiria sp.; G-H. Cipsela e pápus de Stevia grazielae A.S. Quaresma \& J.N. Nakaj.; I. Corola, ápice dos estames e ramos do estilete de Steyermarkina dusenii (Malme) R.M. King \& H. Rob.; J-K. Trichogonia campestris Gardner: J. Corola com lacínias pilosas e ramos do estilete; K. Cipsela e pápus plumoso. 


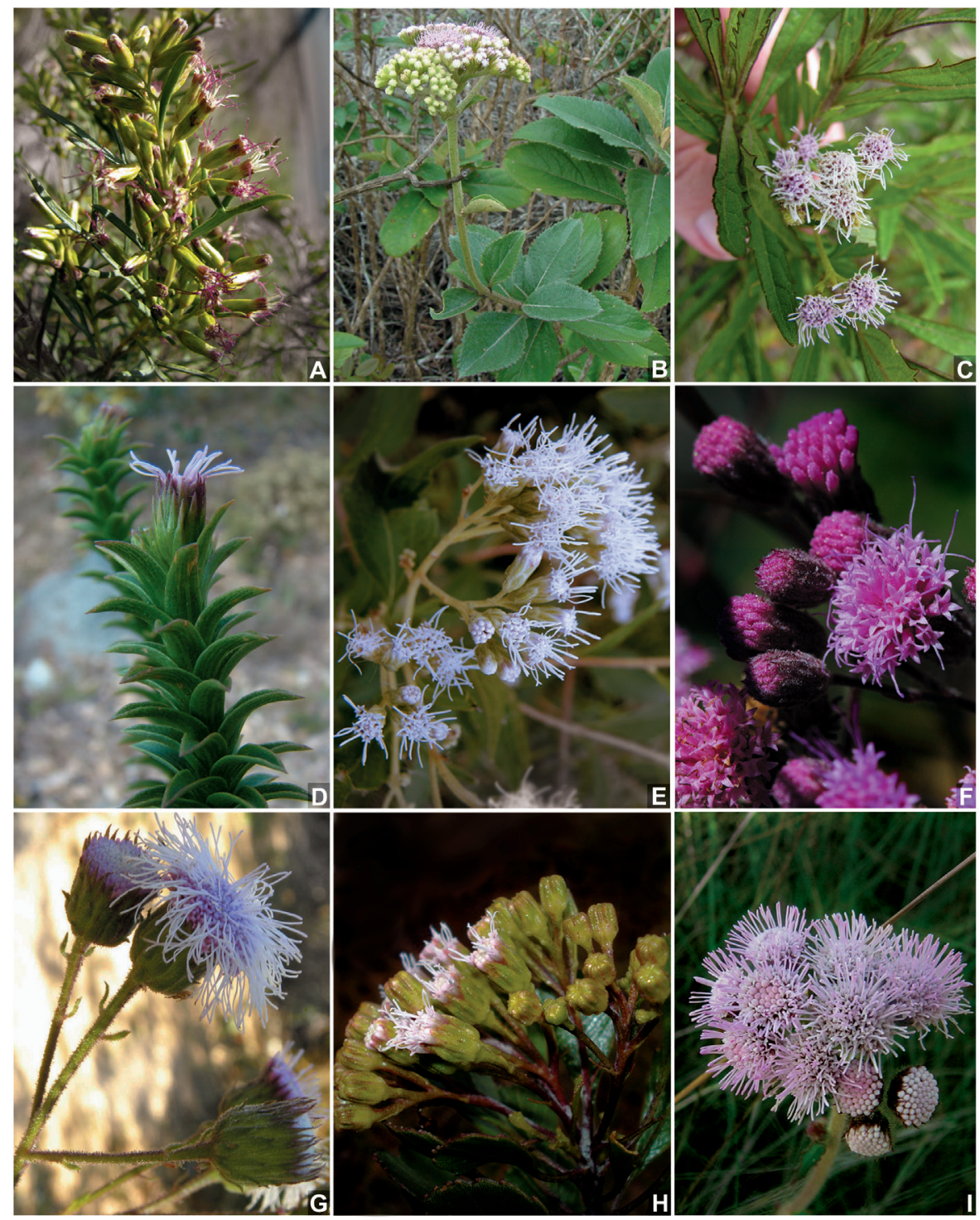

Figura 24. Eupatorieae. A. Acanthostyles buniifolius (Hook. ex Arn.) R.M. King \& H. Rob.; B. Acritopappus micropappus (Baker) R.M. King \& H. Rob.; C. Ageratum fastigiatum (Gardner) R.M. King \& H. Rob.; D. Agrianthus myrtoides Mattf.; E. Austroeupatorium inulifolium (Kunth) R.M. King \& H. Rob.; F. Ayapana amygdalina (Lam.) R.M. King \& H. Rob.; G. Ayapanopsis oblongifolia (Gardner) R.M. King \& H. Rob.; H. Bahianthus viscosus R.M. King \& H. Rob.; I. Barrosoa betonicaeformis (DC.) R.M. King \& H. Rob. 

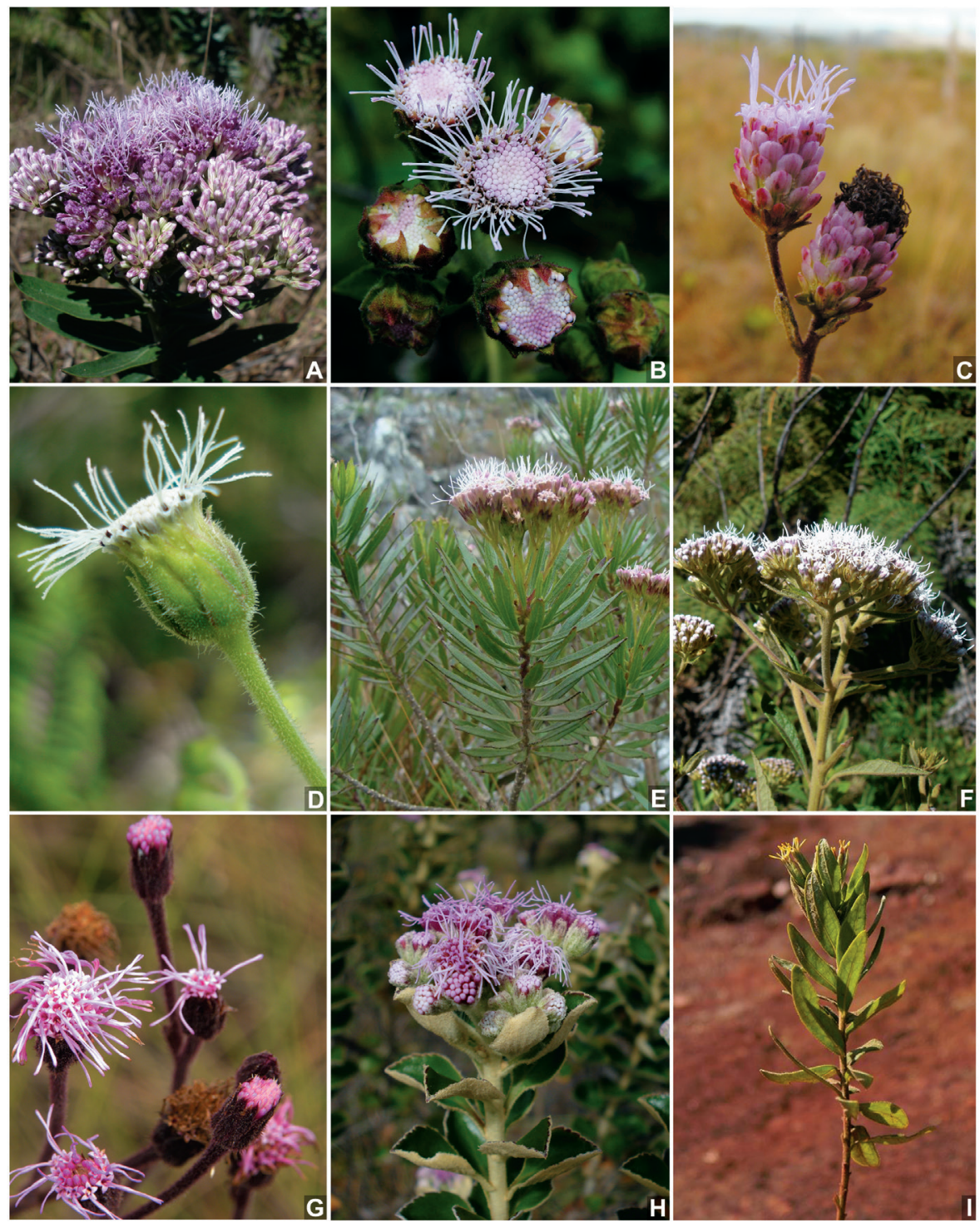

Figura 25. Eupatorieae. A. Campovassouria cruciata (Vell.) R.M. King \& H. Rob.; B. Campuloclinium megacephalum (Mart. ex Baker) R.M. King \& H. Rob.; C. Chromolaena horminoides DC.; D. Diacranthera ulei R.M. King \& H. Rob.; E. Disynaphia praeficta (B.L. Rob.) R.M. King \& H. Rob.; F. Grazielia intermedia (DC.) R.M. King \& H. Rob.; G. Heterocondylus pumilus (Gardner) R.M. King \& H. Rob.; H. Lasiolaena duartei R.M. King \& H. Rob.; I. Leptoclinium trichotomum (Gardner) Benth. 

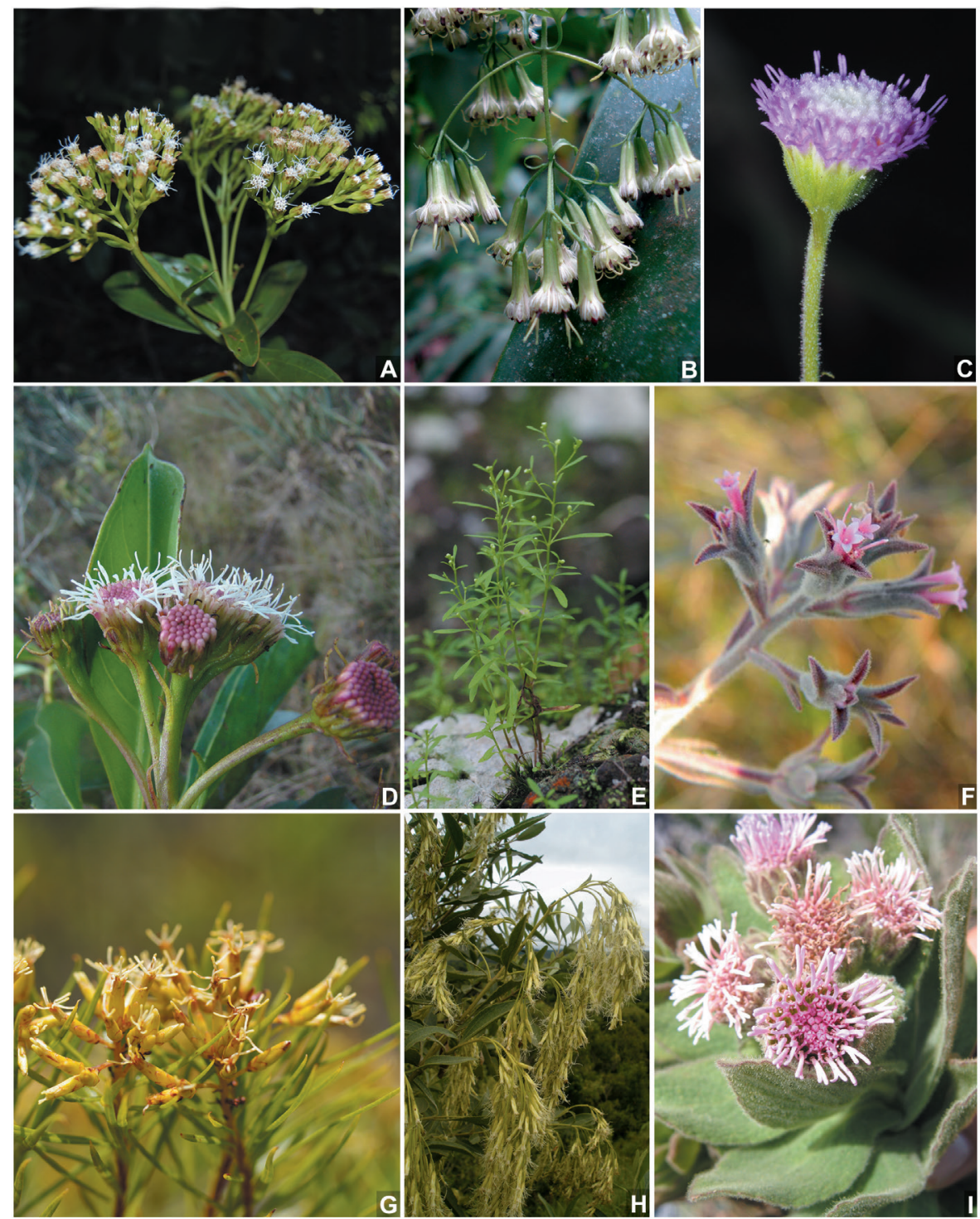

Figura 26. Eupatorieae. A. Litothamnus ellipticus R.M. King \& H. Rob.; B. Mikania ternata (Vell.) B.L. Rob.; C. Monogereion carajensis G.M. Barroso \& R.M. King; D. Morithamnus crassus R.M. King \& H. Rob.; E. Parapiqueria cavalcantei R.M. King \& H. Rob.; F. Planaltoa salviifolia Taub.; G. Pseudobrickellia brasiliensis (Spreng.) R.M. King \& H. Rob.; H. Raulinoreitzia crenulata (Spreng.) R.M. King \& H. Rob.; I. Semiria viscosa D.J.N. Hind. 

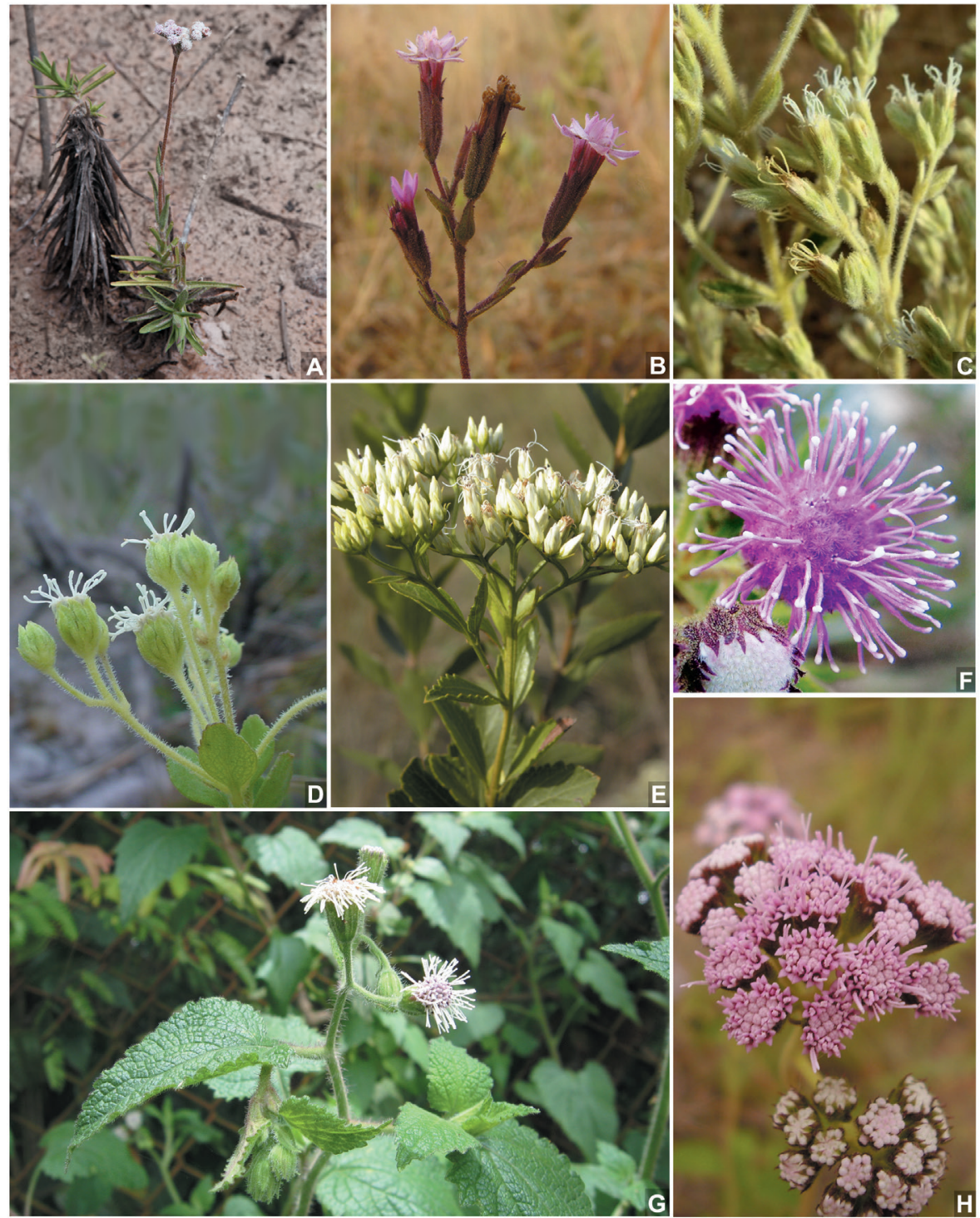

Figura 27. Eupatorieae. A. Scherya bahiensis R.M. King \& H. Rob.; B. Stevia heptachaeta DC.; C. Stomatanthes dictyophyllus (DC.) H. Rob.; D. Stylotrichium rotundifolium Mattf.; E. Symphyopappus cuneatus (DC.) Sch. Bip. ex Baker; F. Trichogonia villosa Sch. Bip. ex Baker; G. Trichogoniopsis adenantha (DC.) R.M. King \& H. Rob; H. Vittetia orbiculata (DC.) R.M. King \& H. Rob. 


\title{
APÊNDICE A
}

\section{GLOSSÁRIO PALINOLÓGICO}

\author{
होon \\ Vania Gonçalves-Esteves \\ Cláudia Barbieri Ferreira Mendonça \\ Roberto Lourenço Esteves
}

A importância do estudo dos grãos de pólen aplicado à sistemática já havia sido valorizada nas primeiras décadas do século passado por Erdtman (1952) e Wodehouse (1935). Stix (1960) elaborou esquemas para explicar a difícil configuração de lacunas e muros de alguns tipos de grãos de pólen da família Asteraceae. Assim, a autora criou 42 tipos polínicos com base na estrutura da exina quando observada em microscopia de luz e eletrônica de transmissão.

Entretanto, foi principalmente na tribo Vernonieae que a investigação dos diferentes atributos associados à variabilidade dos tipos polínicos se mostrou mais relevante como característica diagnóstica útil no estudo dos diferentes gêneros, conforme demonstrado nos trabalhos de Jones (1970, 1973, 1979, 1981, 1982), Kelley e Jones (1977, 1979), Vasanth, Franceschi e Pocock (1993), Robinson (1999), Mendonça e colaboradores (2010), Carrijo e colaboradores (2013), Souza-Souza e colaboradores (2016), Siniscalchi e colaboradores (2017).

Com relação ao número e tipo de aberturas, os grãos de pólen, na maioria das espécies, possuem 3 poros (triporados) ou 3 cólporos (tricolporados), podendo-se encontrar variação no número de aberturas (3-4-colporados), quase sempre, nos grãos de pólen equinados ou espinhosos.

Quando um grão de pólen é isopolar (polos iguais), ele é classificado em 2 partes principais: os polos e a região do equador. 
A região mais elevada do polo é chamada de apocolpo e a região entre as aberturas, de mesocolpo.

Assim, com base em referências bibliográficas, registram-se 3 tipos básicos de grãos de pólen, quanto ao tipo de abertura (porados - Figura 28 , Foto 1; colporados - Figura 28, Fotos 2, 3 e 5) e quanto à ornamentação da sexina (espinhoso e lofado). O lofado pode ser: subequinolofado, equinolofado ou psilolofado.

1. No tipo equinado ou espinhoso, a superfície do grão de pólen é recoberta por espinhos de comprimento igual ou maior 1 micrômetro. Encontrado em espécies de Heliantheae, Eupatorieae, Astereae (Figura 28, Fotos 2, 3 e 4).

Quando os espinhos são menores do que 1 micrômetro, são denominados de microequinados. Encontrado em Stifftioideae e Barnadesieae (Figura 28, Fotos 5 e 6).

Tipo lofado - O tipo lofado pode ser dividido em:

a. Tipo subequinolofado: a superfície é formada por cristas ou muros sem, no entanto, formar lacunas ou malhas na sua maior parte (Figura 28, Fotos 7 e 8).

b. Tipo equinolofado: a superfície do grão de pólen possui cristas ou muros envolvendo depressões, malhas ou lacunas de formas variadas (tetragonais, pentagonais ou hexagonais). Sobre os muros, encontram-se espinhos (Figura 28, Fotos 9, 10 e 11).

c. Tipo psilolofado: a organização é semelhante ao tipo equinolofado, porém não existem espinhos sobre os muros. Esse último tipo ocorre em Barnadesia caryophylla (Vell.) S.S. Blake (Figura 28, Foto 12).

Nos grãos de pólen com a ornamentação lofada (equinolofada ou psilolofada), as lacunas assim organizadas são contabilizadas e denominadas de acordo com a sua localização na superfície do grão de pólen. O número de lacunas varia dentro de um gênero devido à presença ou ausência da lacuna equatorial e/ou presença ou ausência da lacuna polar. Assim, pode-se encontrar grãos de pólen com 27, 29, 30 ou 32 lacunas. 
Classificação das lacunas:

A) Lacuna apertural: lacuna na qual está contida a abertura (Figura 29, Foto $1 \mathrm{~A})$;

B) Lacuna interapertural: encontrada na região do polo, faz contato com a lacuna apertural (Figura 29, Fotos 1, 2 e 3B);

C) Lacuna polar: lacuna situada nos polos (Figura 29, Foto 2C). Em algumas espécies, não se registra lacuna nos pólos e, nesse caso, encontram-se muros formando um "Y" organizado pela união das lacunas abaperturais (Figura 29, Foto 4G);

D) Lacuna abapertural: lacuna posicionada acima e abaixo das extremidades da abertura (lacuna apertural) e, normalmente, entre as interaperturais (Figura 29, Foto 1D);

E) Lacuna parapertural: lacuna situada margeando as aperturais (Figura 29, Fotos 1 e 3E);

F) Lacuna equatorial: lacuna situada na região mediana entre as lacunas paraperturais (Figura 29, Foto 3F).

\section{Literatura recomendada}

CARRIJO, T. T. et al. Pollen morphology of some related genera of Vernonieae (Asteraceae) and its taxonomic significance. Plant Systematics and Evolution, New York, v. 299, n. 7, p. 1275-1283, 2013.

ERDTMAN, G. Pollen morphology and plant taxonomy - Angiosperms. Upsala: Almqvist e Wiksell, 1952.

JONES, S. B. Scanning electron microscopy pollen as an aid to the Systematics of Vernonia (Compositae). Bulletin Torrey Botanical Club, [S.1.], v. 97, p.325-335, 1970.

JONES, S. B. Revision of Vernonia Section Eremosis (Compositae) in North America. Brittonia, Bronx, v. 25, p. 86-115, 1973. 
JONES, S. B. Synopsis and pollen morphology of Vernonia (Composiae: Vernonieae) in the New World. Rhodora, Cambridge, v. 81, p.425-447, 1979. JONES, S. B. Synoptic classification and pollen morphology of Vernonia (Compositae: Vernonieae) in the old world. Rhodora, Cambridge, v. 83, p. 59-75, 1981.

JONES, S. B. The genera of Vernonieae (Compositae) in the southeastern United States. Journal of the Arnold Arboretum, Cambridge, v. 63, p. 489-507, 1982.

KEELEY, S. C.; JONES, S. Taxonomic implications of external pollen morphology to Vernonia (Compositae) in the West Indies. American Journal of Botany, Lancaster, v. 64, p. 576-584, 1977.

KEELEY, S. C.; JONES, S. Distribution of pollen types in Vernonia (Vernonieae - Compositae). Systematic Botany, Kent, v. 4, n. 3, p. 195-202, 1979.

MENDONÇA, C. B. F. et al. Lessingianthus (Vernonieae-Asteraceae): generic and infrageneric relationship based on pollen morphology. Nordic Journal of Botany, Copenhagen, v. 28, n. 3, p. 376-384, 2010.

ROBINSON, H. Generic and subtribal classification of American Vernonieae. Washington: Smithsonian Institution Press, 1999. Smithsonian Contributions to Botany, n. 89).

SINISCALCHI, C. M. et al. The systematic value of pollen morphology in Chresta Vell. ex DC. (Vernonieae, Asteraceae). Review of Palaeobotany and Palynology, Amsterdam, v. 244, p. 182-191, 2017.

SOUZA-SOUZA, R.M.B. et al. Pollen morphology of genus Paralychnophora (Vernonieae - Asteraceae). Palynology, Dallas, v. 40, n. 2, p. 280-288, 2016. STIX, E. Pollen morpholosgische untersuchungen na Compositen. Grana Palynologica, Stockholm, v. 2, p. 41-114, 1960.

VASANTHY, G.; FRANCESCHI, D.; POCOCK, S. Geometric aspects of pollen: polyhedrons (Vernonieae-Asteraceae), rotated symmetric (Trichanthereae - Acanthaceae) and pyramidal to prismatic spinules (NothapodytesIcacinaceae). Grana, Stockholm, v. 2, p. 37-43, 1993. Supplement. WODEHOUSE, R. P. Pollen grains. New York: MacGraw-Hill Book Co. 1935. 

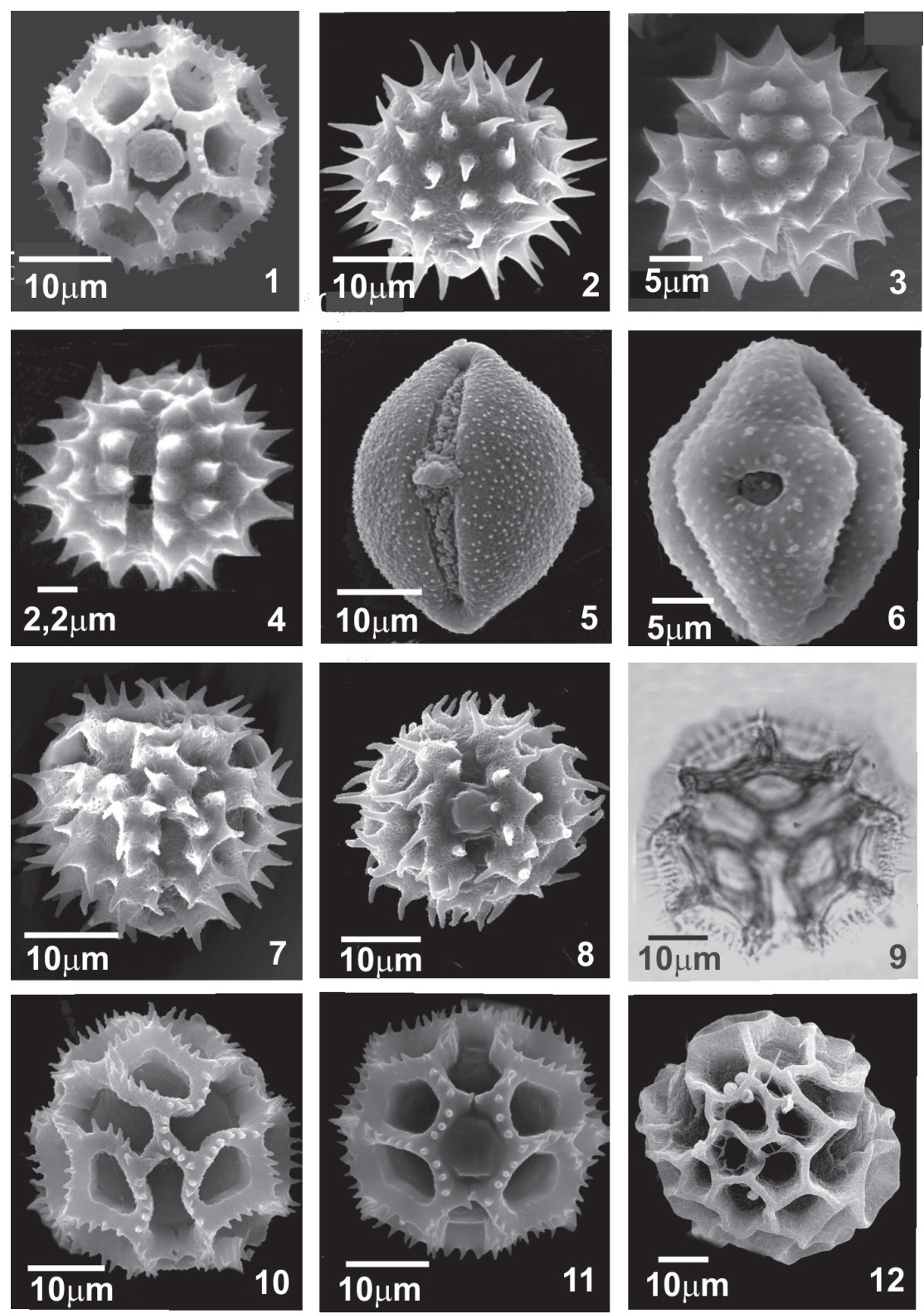

Figura 28. Pseudelephantoppus spicatus (Juss. ex Aubl.) C. F. Baker (Vernonieae), vista equatorial; 2 - Aldama sp. (Heliantheae), vista polar; 3 - Ayapana sp. (Eupatorieae), vista polar; 4 - Astereae (Baccharis sp.), vista equatorial; 5. Stifftia sp. (Stifftioideae), vista equatorial; 6 - Dasyphyllum sp. (Barnadesieae), vista equatorial; 7 - Dasyanthina serrata (Less.) H. Rob., vista polar; 8. D. serrata, vista equatorial; 9 Cyrtocymura scorpioides (Lam.) H. Rob., vista polar; 10 - Echinocoryne stricta (Gardner) H. Rob., vista polar; 11 - E. stricta, vista equatorial; 12 - Barnadesia caryophylla, vista polar. 

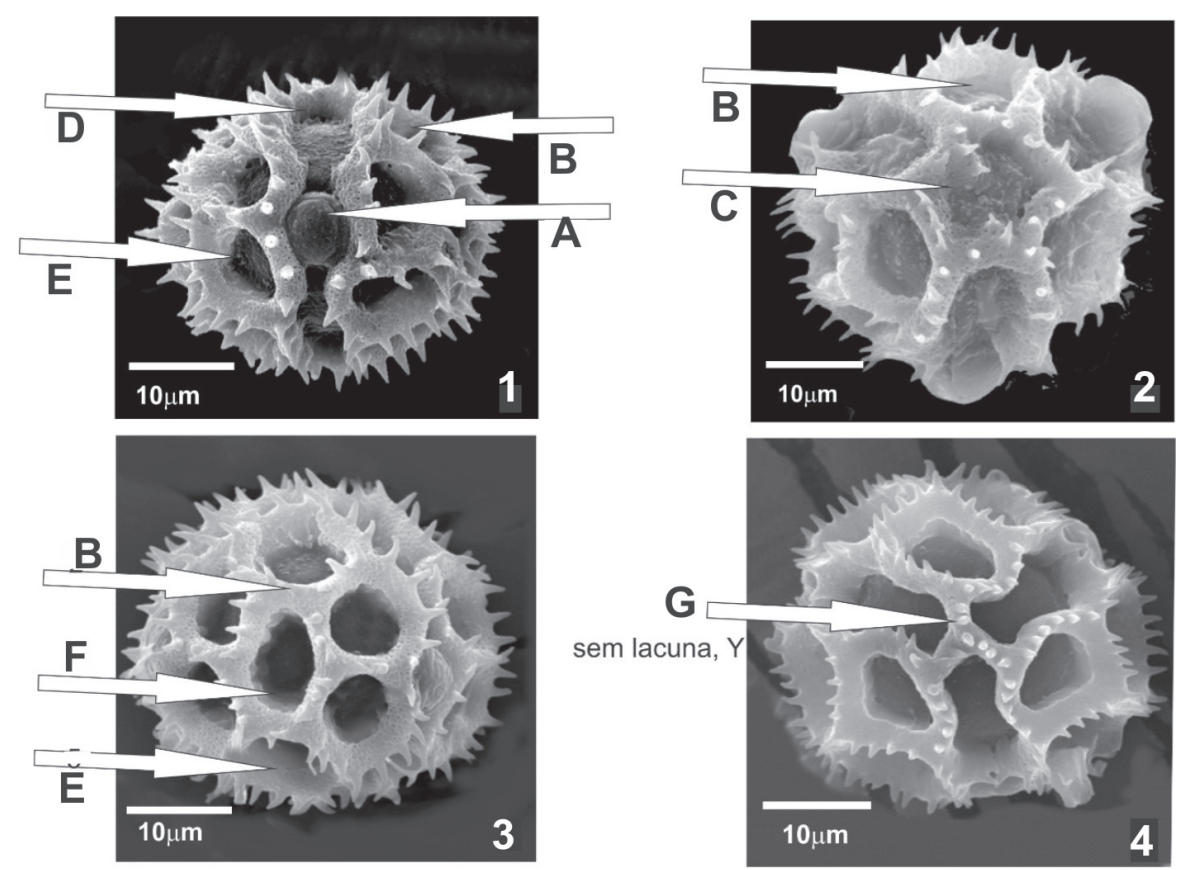

Figura 29. Denominação das lacunas de acordo com suas localizações. 1 - Lessingianthus adenophyllus (Mart. ex DC.) H. Rob., vista equatorial; 2 - Lepidaploa chamissonis (Less.) H. Rob., vista polar; 3 Lessingianthus psilophyllus (DC.) H. Rob., vista equatorial, no mesocolpo; 4 - Echinochoryne stricta, vista polar. As setas indicam: A. lacuna apertura; B. lacuna interapertura; C. lacuna polar; D. lacuna abapertural; E. lacuna parapertural; F. lacuna equatorial. 


\section{APÊNDICE B}

\section{AUTORES DAS FIGURAS E COLETORES}

Figura 1 - A. Alves \& Ogasawara 64; B. Hipotético; C. Melo et al. 10980; D-F. Hipotético; G. Abreu, I. 123; H. Roque, N. 3263; I. Barbosa, E. 2446; J, K. Silva, J.M. 5168; L-N. Roque, N. et al. 3066.

Figura 2 - A. Monge, M.; B. Roque, N.; C. Fraga, C.N.; D. Heiden, G.; E, F. Moura, L.; G-I. Pasini, E.

Figura 3 - A. Pasini, E.; B-C Pastore, M.; D, E. Monge, M.; F, H. Shimizu, G.; G. Moura, L.; I. Souza-Buturi, F.O.

Figura 4 - A-C. Hatschbach, G. 68368; D-E. Viana, P.L. et al. 3459; F. Mota, N.F.O. 1251; G, H. Roque, N. et al. 4111; I. Roque \& Funk 2013; J. Medeiros, J.D. s/n (ALCB 106107); K. Lara s/n (Doação do PAMG); L. Moura, L.M. 118.

Figura 5 - A. Souza-Buturi, F.O.; B. Roque, N.; C. Souza-Buturi, F.O.; D. Monge, M.; E. Deble, A.S.O.; F-H. Roque, N.; I. Moura, L.

Figura 6 - A. Medeiros, J.D.; B-G. Schneider, A.A.S.; H, I. Moura, L.

Figura 7 - A. Moura, L. et al. 178; B-D. Santana, F.A. et al. 21; E. Roque, A.A. 1197; F, G. Santana, F.A. 17; H. Reprodução Borges, L.; I. Campos, C.J. \& Lima, J.M. 123; J. Ogasawara, H.A. 340; K, L. Guedes, M.L. et al. 20077; M. Roque, N. et al. 2705.

Figura 8 - A, B. Roque, N. et al. 3526; C. Silva, J.M. et al. 4485; D. Ogasawara H.A. 115; E, G. Reprodução Borges, L.; F. Roque \& Bautista 2008; H, I. Guedes, M.L. et al. 17527; J. Vieira, L.P. 65; K-M. Reprodução Borges, L.; N-P. Guedes, M.L. et al. 17652.

Figura 9 - A-B. Hage, J.L. \& Santos, E.B. 2090; C. Guedes, M.L. et al. 13840; D. Ogasawara, H.A. 240; E. Roque, N. \& Quaresma, A.S. 3732; F. Hurbath, F. \& Aguiar, L.G.P.A. 56; G. R. Forzza et al. 3480; H. Roque \& Bautista 2008; I. Ribas, O.S. 7489; J. Viana, P.L. \& Mota, N.F.O. 1825; K. Meireles et al. 447; L. Silva, J.M. 6968. 
Figura 10 - A. Bringel Jr., J.; B, C. Alves, L.J.; D. Lovo, J; E. Mercadante, M.; F. Siniscalchi; G-H. Loeuille, B.; I. Moura, L.

Figura 11 - A, B, C, H, I. Roque, N.; D. Gonella, P.; F. Mercadante, M., E, G. Moura, L.

Figura 12 - A, D, F, H. Loeuille, B.; B, C, E. Roque, N.; H. Moore; I. Moura, L. Figura 13 - A. Gentry, A. \& Zardini, E.M. 49301; B, C. Harley, R.M. et al. PCD 4306; D. Guedes, M.L. et al. 20152; E-G. Hurbath, F. 11; H. Moura, L. 162; I. Melo, E. 9907; J. Schinini, A. 19060; K. Hatschbach, G. 78104; L. Amorim, M.R. 01; M-N. W. Hoehne s/n (ALCB 039803).

Figura 14 - A. Roque, N.; B, C. Moura, L.; D. Dittrich, V.A.O.; E. Moura, L.; F, G, I. Teles, A.M.; H. Viana, P.L.

Figura 15 - A-I. Heiden, G.

Figura 16 - A-F. Schneider, A.A.S.; G-I. Monge, M.

Figura 17 - A. Moura, L.M. 122; B. Guedes, M.L. 17374; C-E. Roque \& Carvalho 2011; F. Guedes, M.L. 13200; G. Roque, N. 2113; H. M. Campos 56; I. Miranda, A.M. 6306; J. Bautista, H.P. PCD 3457; K. Alves, M. \& Ogasawara, H.A. 64; L, M. Guedes, M.L. \& Hind, D.J.N. 17; N, O. Alves, M. 137; P. Guedes, M.L. 20751.

Figura 18 - A-D, F, J, K. Moura, L.; E, G, H, I. Roque, N.

Figura 19 - A-C, G, H. Moura, L.; D-F. Magenta, M.A.G.

Figura 20 - A-B. Abreu, I. 96; C. Miranda, A.M. 2421; D. Alves, M. 46; E. Roque, N. FCO 14; F. Alves, M.M.B. 6; G. Alves, M. 256; H. Mendes, O.T. s/n (ALCB 7203); I. Alves, M. 141; J. Alves, M. 304; K. Oliveira, R.P. 527.

Figura 21 - A. Bringel Jr., J.; B, C, E, G. Moura, L.; D. Surerus, A.; F. Ogasawara, H.A.; H. Vieira, T.

Figura 22 - A. Wasum, R. \& Scur, L. 3944 (BHCB); B. Fendrich, R. 19; C. Roque, N. 2932; D. Quaresma, A.S. \& Cota, M.M.T. 399; E. Teles, A.M. et al. 377 ; F. Quaresma, A.S. 319; G. Guedes, M.L. 12745; H. R.M. Harley et al. 20645; I. Moura, L. 96; J. Cid Ferreira, C.A. 2555; K. Tameirão Neto, E. \& França, G.S. 85; L. Melo, P.H.A. \& Melo Jr., E.A. 1364; M, N. Ramos, C.E. 446; O. Roque, N. 3070; P. Watanabe, M.T.C. 56. 
Figura 23 - A. Roque, N. 2862; B. P. Cavalcante 2136; C. Bunger, M.O. et al. 450; D. Hatschbach, G. 79035; E. Roque, N. 3885; F. Ogasawara, H.A. 167; G, H. Quaresma, A.S. \& Cota, M.M.T. 379; I. Silva, J.M. \& Abe, L.M. 3080; J, K. Roque, N. 3911.

Figura 24 - A, E. Gutierrez, D.G.; B, D. Roque, N.; C. Rivera, V.L.; F. Mercadante, M.; G. Fernandes, A.C.; H, I. Ferreira, S.C.

Figura 25 - A, F. Hattori, E.K.O; B. Mercadante, M.; C. Roque, N.; D, H. Ferreira, S.C.; E. Quaresma, A.S.; G. Fernandes, A.C.; I. Bringel Jr., J.B.

Figura 26 - A, I. Ferreira, S.C.; B. Ritter, M.R.; C, E, G. Viana, P.L.; D. Roque, N.; F. Bringel, Jr, J.B.; H. Hattori, E.K.O.

Figura 27 - A. Moura, L.; B, D. Roque, N.; C, F. Quaresma, A.S.; E. Fernandes, A.C.; G, H. Ferreira, S.C. 


\section{APÊNDICE C}

\section{ÍNDICE DE GÊNEROS E ESPÉCIES}

Acanthospermum Schrank 198

Acanthostyles R.M. King \& H. Rob. 129

Acanthostyles buniifolius (Hook. \& Arn.) R.M. King \& H. Rob. 225, 227

Achillea L. 150

Achillea millefolium L. 159

Acmella Rich. ex Pers. 188

Acmella uliginosa (Sw.) Cass. 203

Achyrocline (Less.) DC. 131, 132, 133, 134

Achnopogon Maguire, Steyerm. \& Wurdack 62

Acilepidopsis H. Rob. 108

Acritopappus R.M. King \& H. Rob. 213

Acritopappus micropappus (Baker) R.M. King \& H. Rob. 227

Adenocaulon Hook. 45

Adenostemma J.R. Forst. \& G. Forst. 211

Adenostemma brasilianum (Pers.) Cass. 225

Ageratum L. 213

Ageratum fastigiatum (Gardner) R.M. King \& H. Rob. 227

Agrianthus Mart. ex DC. 215, 216

Agrianthus empetrifolius Mart. ex DC. 225

Agrianthus myrtoides Mattf. 227

Albertinia Spreng. 108

Albertinia brasiliensis Spreng. 113

Aldama La Llave 191

Aldama sp. 235

Aldama linearifolia (Chodat) E.E. Schill. \& Panero 205

Aldama santacatarinensis (H. Rob. \& A.J. Moore) E.E. Schill. \& Panero 205

Allocephalus Bringel Jr., J.B.A., J.N. Nakaj. \& H. Rob. 110 
Allocephalus gamolepis Bringel Jr., J.B.A., J.N. Nakaj. \& H. Rob. 116 Alomiella R.M. King \& H. Rob. 222

Ambrosia L. 187

Ambrosia artemisiifolia L. 203

Anastraphia D. Don 61, 77, 78

Anteremanthus H. Rob. 107

Anteremanthus piranii Roque \& F.A. Santana 116

Anthemis L. 150

Aphyllocladus Wedd. 57

Apopyros G.L. Neson 140

Apostates N. S. Lander 182

Arctium L. 186

Arctium lappa L. 95

Arnaldoa Cabrera 38

Arnica montana L. 20

Arrojadocharis Mattf. 215

Artemisia L. 150, 151

Artemisia absinthium L. 20

Artemisia sp. 159

Aspilia Thouars 186, 190

Aspilia leucoglossa Malme 205

Aspilia riedelii Baker 205

Aspilia subalpestris Baker 203

Asteropsis Less. 141

Asteropsis megapotamica (Spreng.) Marchesi et al. 147

Austrobrickellia R.M. King \& H. Rob. 218

Austrocritonia R.M. King \& H. Rob. 76

Austroeupatorium R.M. King \& H. Rob. 221

Austroeupatorium inulifolium (Kunth) R.M. King \& H. Rob. 227

Austroeupatorium silphiifolium (Mart.) R.M. King \& H. Rob. 225

Ayapana Spach 222

Ayapana amygdalina (Lam.) R.M. King \& H. Rob. 227

Ayapana sp. 235 
Ayapanopsis R.M. King \& H. Rob. 222

Ayapanopsis oblongifolia (Gardner) R.M. King \& H. Rob. 227

Baccharidastrum Cabrera 140

Baccharidiopsis G.M. Barroso 140

Baccharis L. 140, 141

Baccharis macrophylla Dusén 147

Baccharis sp. 235

Bahianthus R.M. King \& H. Rob. 216

Bahianthus viscosus R.M. King \& H. Rob. 227

Balduina Nutt. 162

Baltimora L. 191

Barnadesia Mutis ex L. f. 37, 38, 39

Barnadesia caryophylla (Vell.) S.F. Blake 49, 232, 235

Barrosoa R.M. King \& H. Rob. 217

Barrosoa betonicaeformis (DC.) R.M. King \& H. Rob. 227

Barrosoa organensis (Gardner) R.M. King \& H. Rob. 225

Bartlettina R.M. King \& H. Rob. 221

Bejaranoa R.M. King \& H. Rob. 217

Berroa Beauverd 132, 133

Berroa gnaphalioides (Less.) Beauverd 133

Bishopiella R.M. King \& H. Rob. 214

Bidens L. 165, 166, 167, 168

Bidens pilosa L. 203

Blainvillea Cass. 186, 190

Blainvillea acmella (L.) Philipson 203, 205

Blanchetia DC. 107

Borrichia Adans. 186, 188

Brachylaena R. Br. 81

Brachylaena discolor DC. 82, 93, 95

Brickellia Elliott 218

Caatinganthus H. Rob. 104

Caatinganthus rubropappus (Soar. Nunes) H. Rob. 113

Calea L. 102 
Calea angusta S.F. Blake 203

Calea candolleana (Gardner) Baker 204

Calea harleyi H. Rob. 204

Calea morii H. Rob. 203, 204

Calendula officinalis L. 20

Calyptocarpus Less. 186, 191

Campovassouria R.M. King \& H. Rob. 219

Campovassouria cruciata (Vell.) R.M. King \& H. Rob. 228

Campuloclinium DC. 216

Campuloclinium hirsutum Gardner 225

Campuloclinium megacephalum (Mart. ex Baker) R.M. King \& H. Rob. 228

Carduus L. 86

Carduus nutans L. 95

Carthamus L. 86, 87

Carthamus lanatus L. 95

Catolesia D.J.N. Hind 215

Catolesia mentiens D.J.N. Hind 225

Cavalcantia R.M. King \& H. Rob. 214

Centaurea L. 86, 87

Centaurea melitensis L. 95

Centaurea tweediei Hook. \& Arn. 95

Centratherum Cass. 106

Centratherum punctatum Cass. 116

Cephalopappus Nees \& Mart. 52, 53

Chaptalia Vent. 44, 45, 46

Chaptalia integerrima (Vell.) Burkart 35, 49

Chaptalia nutans (L.) Polak 49

Chaptalia runcinata Kunth. 49

Chevreulia Cass. 133, 134

Chacoa R.M. King \& H. Rob. 221

Chimantaea Maguire, Steyerm. \& Wurdack 61

Chionolaena DC. 131, 132, 133, 134

Chionolaena Jeffreyi H. Rob. 129 
Chresta Vell. ex DC. 105

Chresta harleyi H. Rob. 113

Chresta sphaerocephala DC. 116

Chromolaena DC. 212

Chromolaena horminoides DC. 228

Chronopappus DC. 106

Chronopappus bifrons (DC. ex Pers.) DC. 113

Chrysanthellum Rich. 167, 168

Chrysanthemum L. 150, 151

Chrysanthemum indicum L. 20

Chrysanthemum sp. 129

Chrysolaena H. Rob. 110

Chrysolaena obovata (Less.) M. Dematt. 116

Chrysolaena platensis (Spreng.) H. Rob. 113

Chucoa Cabrera 77

Chuquiraga Juss. 38

Cichorium L. 89, 90

Cichorium endivia L. 20

Cichorium intybus L. 20

Cirsium Mill. 86

Cirsium vulgare (Savi) Tem. 95

Clibadium F. Allam. ex L. 187

Coleostephus Cass. 150, 151

Coleostephus myconis (L.) Cass 159

Cololobus H. Rob. 108

Cololobus rupestris (Gardner) H. Rob. 116

Cnicothamnus Griseb. 77

Conocliniopsis R.M. King \& H. Rob. 217

Conocliniopsis prasiifolia (DC.) R.M. King \& H. Rob. 35

Conyza Less. 140, 141, 142

Conyza bonariensis (L.) Cronquist 140

Conyza primulifolia (Lam.) Cuatrec. \& Lourteig 129

Conyza sumatrensis (Retz.) E. Walker 140 
Coreopsis L. 165, 168

Cosmos Cav. 165, 166, 167, 168

Cosmos sulphureus Cav. 203, 204

Cotula L. 150, 151

Cotula australis (Sieber ex Spreng.) Hook. f. 159

Crepis L. 89, 90, 91

Crepis capillaris (L.) Wallr. 90

Crepis setosa Haller f. 90

Critonia P. Browne 220

Criscia Katinas 52, 54

Critoniopsis Sch. Bip. 107

Critoniopsis quinqueflora (Less.) H. Rob. 116

Curio rowleyanus (H. Jacobsen) P.V. Heath 125

Cyanthillium Blume 109

Cyclolepis Gilles ex D. Don 77

Cynara L. 86

Cynara scolymus L. 20

Cyrtocymura H. Rob. 108

Cyrtocymura harleyi (H. Rob.) H. Rob. 113, 116

Cyrtocymura scorpioides (Lam.) H. Rob. 235

Dahlia Cav. 165, 168

Dasyanthina H. Rob. 109

Dasyanthina serrata (Less.) H. Rob. 235

Dasycondylus R.M. King \& H. Rob. 216

Dasyphyllum Kunth 38, 39

Dasyphyllum donianum (Gardner) Cabrera 35

Dasyphyllum spinescens (Less.) Cabrera 49

Dasyphyllum sprengelianum (Gardner) Cabrera 49

Dasyphyllum sp. 235

Delilia Spreng. 24, 189

Delilia biflora (L.) Kuntze 203

Dendrophorbium (Cuatrec.) C. Jeffrey 125

Dendrophorbium pellucidinerve (Sch. Bip. ex Baker) C. Jeffrey 115, 130 
Diacranthera R.M. King \& H. Rob. 216

Diacranthera ulei R.M. King \& H. Rob. 225, 228

Dimerostemma Cass. 191

Dimerostemma vestitum (Baker) S.F. Blake 207

Dinoseris Griseb. 62

Diodontium F. Muell. 166

Dissothrix A. Gray 218

Disynaphia Hook. \& Arn. ex DC. 219

Disynaphia praeficta (B.L. Rob.) R.M. King \& H. Rob. 228

Doniophyton Wedd. 138

Duidaea S.F. Blake 62

Duseniella K. Schum. 38

Echinacea Moench 186, 188

Echinocoryne H. Rob. 110

Echinocoryne stricta (Gardner) H. Rob. 235

Eclipta L. 189

Eclipta prostrata (L.) L. 203, 207

Egletes Cass. 141

Egletes viscosa (L.) Less. 129, 140

Eitenia R.M. King \& H. Rob. 212

Eitenia polysecta R.M. King \& H. Rob. 225

Elaphandra Strother 190

Elephantopus L. 103

Elephantopus mollis Kunth 113

Eleutheranthera Poit. ex Bosc. 186, 189

Emilia Cass. 126

Emilia fosbergii Nicolson 115, 125, 130

Emilia sonchifolia (L.) DC. 125

Epaltes Cass. 155, 156

Enydra Lour. 172

Enydra anagallis Gardner 172

Enydra radicans (Willd.) Lack 203

Eremanthus Less. 105, 106 
Eremanthus glomerulatus Less. 117

Erechtites Raf. 125

Erechtites hieracifolius (L.) Raf. ex DC. 115, 130

Eupatoriopsis Hieron. 212

Eupatorium L. 5, 209, 210

Eurydochus Maguire \& Wurdack 62, 63

Exostigma G. Sancho 141

Facelis Cass. 133

Facelis retusa (Lam.) Beauverd 133

Fitchia Hook. f. 167

Flaveria Juss. 176, 177

Fleischmannia Sch. Bip. 214

Fleischmannia remotiflora (DC.) R.M. King. \& H. Rob. 225

Fulcaldea Poir. ex Lam. 38, 39

Fulcaldea stuessyi Roque \& V.A. Funk 35

Gaillardia Foug. 162, 162

Gaillardia pulchella Foug. 129

Galinsoga Ruiz \& Pav. 198

Galinsoga parviflora Cav. 206

Gamochaeta Wedd. 131, 133, 134

Gamochaeta pensylvanica (Willd.) Cabrera 129

Gardnerina R.M. King \& H. Rob. 214

Gardnerina angustata (Gardner) R.M. King \& H. Rob. 225

Gazania Gaertn. 20

Gerbera L. 20, 46

Gochnatia Kunth 73, 77, 79

Gochnatia rotundifolia (Less.) Cabrera 78

Glossarion Maguire \& Wurdack 62, 63

Glossocardia Cass. 166

Gnaphaliothamnus Kirp. 131

Gnaphalium L. 131, 134

Gnaphalium polycaulon Pers. 133

Gongylolepis R.H. Schomb. 62, 63 
Gongylolepis martiana (Baker) Steyerm. \& Cuatrec. 50

Gorceixia Baker 104

Goyazianthus R.M. King \& H. Rob. 218

Graphistylis B. Nord. 126

Graphistylis dichroa (Bong.) D.J.N. Hind 130

Graphistylis riopretensis A.M. Teles \& B. Nord. 115

Grazielia R.M. King \& H. Rob. 219

Grazielia intermedia (DC.) R.M. King \& H. Rob. 228

Grindelia Willd. 141, 142

Grindelia brachystephana Griseb. 129

Grindelia puberula Hook. \& Arn. 147

Guayania R.M. King \& H. Rob. 221

Guizotia Cass. 198, 199

Guizotia abyssinica (L.f.) Cass. 198

Gymnanthemum Cass. 109

Gymnanthemum amygdalinum (Delile) Sch. Bip. ex Walp. 117

Gymnocondylus R.M. King \& H. Rob. 222

Gymnocoronis DC. 211

Gypothamnium Phil. 57

Gyptidium R.M. King \& H. Rob. 217

Gyptis Cass. 217

Hatschbachiella R.M. King \& H. Rob. 221

Hebeclinium DC. 221

Hebeclinium macrophyllum (L.) DC. 225

Helianthus L. 20, 186, 191

Helianthus annuus L. 20

Helichrysum Mill. 132, 134

Helichrysum foetidum (L.) Moench 133

Helenium L. 162, 163

Heterocoma DC. 107

Heterocoma erecta (H. Rob.) Loeuille, J.N. Nakaj. \& Semir 113, 117

Heterocondylus R.M. King \& H. Rob. 222

Heterocondylus pumilus (Gardner) R.M. King \& H. Rob. 228 
Heterocypsela H. Rob. 110

Heterosperma Cav. 165

Heterothalamus Less. 140

Hieracium L. 89, 90, 91

Hoehnephytum Cabrera 125

Holocheilus Cass. 52, 53

Holocheilus pinnatifidus (Less.) Cabrera 50

Hololepis DC. 107

Hololepis pedunculata (DC. ex Pers.) DC. 117

Huarpea Cabrera 38

Hyaloseris Griseb. 62

Hymenopappus L' Hér. 182

Hymenoxys Cass. 162

Hypericophyllum Steetz 182

Hypochaeris L. 89, 90, 91

Hysterionica Willd. 143

Hysterionica pinnatiloba Matzenb. \& Sobral 147

Ianthopappus Roque \& D.J.N. Hind 73

Ianthopappus corymbosus (Less.) Roque \& D.J.N. Hind 74, 94

Ichthyothere Mart. 198, 199

Idiothamnus R.M. King \& H. Rob. 220

Imeria R.M. King \& H. Rob. 220

Inulopsis O. Hoffmann 141

Inulopsis scaposa (DC.) O. Hoffm. 147

Isocarpha R. Br. 212

Isostigma Less. 167, 168

Isostigma peucedanifolium (Spreng.) Less. 204

Jaegeria Kunth 199

Jaumea Pers. 176, 177

Jungia L. F. 53

Kaunia R.M. King \& H. Rob. 215

Koanophyllon Arruda 220, 221

Koanophyllon adamantium (Gardner) R.M. King \& H. Rob. 225 
Lactuca L. 89, 90, 91

Lactuca sativa L. 20, 90

Lactuca serriola L. 90

Lactuca sp. 93

Lagascea Cav. 166, 167

Lagascea mollis Cav. 206

Lapidia Roque \& S.C. Ferreira 214

Lapsana L. 90

Lapsana communis L. 90

Lasiolaena R.M. King \& H. Rob. 216

Lasiolaena blanchetii (Sch. Bip. ex Baker) R.M. King \& H. Rob. 225

Lasiolaena duartei R.M. King \& H. Rob. 228

Lepidaploa (Cass.) Cass. 110

Lepidaploa chamissonis (Less.) H. Rob. 236

Lepidaploa cotoneaster (Willd. ex Spreng.) H. Rob. 114, 117

Leptoclinium (Nutt.) Benth. \& Hook. f. 218

Leptoclinium trichotomum (Gardner) Benth. 228

Leptostelma D. Don 142

Leptostelma camposportoi (Cabrera) A.M. Teles \& Sobral 147

Lessingianthus $\mathrm{H}$. Rob. 110

Lessingianthus adenophyllus (Mart. ex DC.) H. Rob. 236

Lessingianthus asteriflorus (Mart. ex DC.) H. Rob. 114

Lessiangianthus monocephalus (Gardner) H. Rob. 117

Lessingianthus psilophyllus (DC.) H. Rob. 236

Leucanthemum Mill. 150, 151

Leucanthemum vulgare Lam. 159

Leucomeris D. Don 73

Leucopholis Gardner 131

Liabellum Rydb. 97

Liabum Adans. 97

Liabum acuminatum Rusby 98

Liabum amplexicaule Poepp. \& Endl. 98

Litothamnus R.M. King \& H. Rob. 214 
Litothamnus ellipticus R.M. King \& H. Rob. 229

Lomatozona Baker 212

Loxothysanus B.L. Rob. 182

Lucilia Cass. 133, 134

Lulia Zardini 45

Lychnophora Mart. 105, 106

Lychnophora granmogolensis (Duarte) D.J.N. Hind 117

Lychnophora tomentosa (Mart. ex DC.) Sch. Bip. 115, 117

Lycoseris Cass. 57, 58

Lycoseris boliviana Britton 58

Macropodina R.M. King \& H. Rob. 216

Malmeanthus R.M. King \& H. Rob. 220

Maschalostachys Loeuille \& Roque 106

Maschalostachys mellosilvae Loeuille \& Roque 113

Matricaria L. 150, 151

Matricaria recutita L. 20

Mattfeldanthus H. Rob. \& R.M. King 108

Mattfeldanthus mutisioides H. Rob. \& R.M. King 114

Megaliabum Rydb. 97

Melampodium L. 199

Melampodium paniculatum Gardner 206

Melanthera Rohr 190

Melanthera latifolia (Gardner) Cabrera 207

Mesanthophora H. Rob. 110

Micropsis DC. 133

Microgyne Less. 142

Microgyne trifurcata Less. 147

Minasia H. Rob. 105

Minasia alpestris (Gardner) H. Rob 114, 117

Mikania Willd. 211

Mikania ternata (Vell.) B.L. Rob. 229

Monogereion G.M. Barroso \& R.M. King 222

Monogereion carajensis G.M. Barroso \& R.M. King 226, 229 
Montanoa Cerv. 186, 190

Montanoa sp. 207

Moquinia DC. 119, 120

Moquinia racemosa (Spreng.) DC. 115, 130

Moquiniastrum (Cabrera) G. Sancho 77, 79

Moquiniastrum paniculatum (Less.) G. Sancho 93, 94

Moquiniastrum polymorphum (Less.) G. Sancho 94

Morithamnus R.M. King, H. Rob. \& G.M. Barroso 214

Morithamnus crassus R.M. King \& H. Rob. 226, 229

Mutisia L.f. 45, 46

Mutisia campanulata Less. 49

Mutisia coccinea A. St. Hill 35

Mutisia lutzii G. Barroso 45

Neblinaea Maguire \& Wurdack 62, 63

Neja D. Don 142

Neja filiformis (Spreng.) Nees 147

Neocabreria R.M. King \& H. Rob. 220

Neocabreria serrulata (DC.) R.M. King. \& H. Rob. 226

Noticastrum DC. 140, 142

Nouelia Franch. 73

Oblivia Strother 186, 189

Onoseris Willd. 57, 58

Onoseris brasiliensis Cabrera 58

Onoseris fraterna S.F. Blake 58

Ophryosporus Meyen 221

Orthopappus Gleason 103

Pacourina Aubl. 108

Pacourina edulis Aubl. 118

Panphalea Lag. 52, 53

Parachionolaena M.O. Dillon \& Sagást 131

Paralychnophora MacLeish 106

Paralychnophora atkinsiae D.J.N. Hind 114

Paralychnophora harleyi (H. Rob.) D.J.N. Hind 118 
Parapiqueria R.M. King \& H. Rob. 222

Parapiqueria cavalcantei R.M. King \& H. Rob. 229

Parthenium L. 165, 186, 187

Parthenium hysterophorus L. 206

Pectis L. 176, 177

Pentacalia Cass. 125

Pentacalia desiderabilis (Vell.) Cuatrec. 115

Pentaphorus D. Don 61, 77

Perdicium L. 45

Perezia Lag. 53

Perezia squarrosa subsp. cubaetensis (Less.) Vuilleumemier 50

Perymenium Schrad. 186, 190

Picris L. 90, 91

Picris echioides L. 90

Picrosia D. Don 90

Picrosia longifolia D. Don 90

Picrosia cabreriana A.G. Schulz 90

Pilosella Hill 89

Pinillosia Ossa ex DC. 166

Piptocarpha R. Br. 107

Piptocoma Cass. 108

Piptolepis Sch. Bip. 107

Piptolepis campestris Semir \& Loeuille 118

Piqueriella R.M. King \& H. Rob. 213

Plagiocheilus Arn. ex DC. 141

Planaltoa Taub. 218

Planaltoa salviifolia Taub. 229

Platypodanthera R.M. King \& H. Rob. 216

Platypodanthera melissifolia (DC.) R.M. King \& H. Rob. 225

Plazia Ruiz \& Pav. 57

Pluchea Cass. 155, 156, 159

Pluchea sagittalis (Lam.) Cabrera 159

Podocoma Cass. 141, 143 
Podocoma bellidifolia Baker 147

Podocoma notobellidiastrum (Griseb.) G.L. Nesom 129

Porophyllum Guett. 176, 177

Porophyllum ruderale (Jacq.) Cass. 203

Porophyllum sp. 205

Praxelis Cass. 212

Praxeliopsis G.M. Barroso 212

Prestelia Sch. Bip. 105

Prestelia eriopus Sch. Bip. 118

Prolobus R.M. King \& H. Rob. 217

Proteopsis Mart. \& Zucc. ex Sch. Bip. 105

Proteopsis argentea Mart. \& Zucc. ex Sch. Bip. 114, 118

Pseudelephantopus Rohr 103

Pseudelephantopus spicatus (Juss. ex Aubl.) C.F. Baker 114

Pseudobrickellia R.M. King \& H. Rob. 218

Pseudobrickellia brasiliensis (Spreng.) R.M. King \& H. Rob. 229

Pseudognaphalium Kirp. 131, 132, 133, 134

Pseudogynoxys (Greenm.) Cabrera 126

Pseudogynoxys cabrerae H. Rob. \& Cuatrec. 125, 129

Pseudoligandra M.O. Dillon \& Sagást. 131

Pseudostifftia H. Rob. 119, 120

Pseudostifftia kingii H. Rob. 130

Pterocaulon Elliott 155, 156

Pterocaulon polystachyum DC. 159

Quelchia N.E. Br. 61, 62

Radlkoferotoma Kuntze 213

Raulinoreitzia R.M. King \& H. Rob. 219

Raulinoreitzia crenulata (Spreng.) R.M. King \& H. Rob. 226, 229

Richterago Kuntze 77, 79

Richterago arenaria (Baker) Roque 94

Richterago discoidea (Less.) Kuntze 93, 94

Riencourtia Cass. 187

Riencourtia tenuifolia Gardner 206 
Rolandra Rottb. 104

Rolandra fruticosa (L.) Kuntze 114, 118

Rudbeckia L. 186, 188

Salcedoa Jiménez Rodr. \& Katinas 62

Salmea DC. 188

Santosia R.M. King \& H. Rob. 219

Sanvitalia Lam. 186, 189

Schlechtendalia Less. 31, 39

Schlechtendalia luzulifolia Less. 49

Schkuhria Roth 182

Schkuhria pinnata (Lam.) Kuntze ex Thell. 182

Scherya R.M. King \& H. Rob. 213

Scherya bahiensis R.M. King \& H. Rob. 226, 230

Sciadocephala Mattf. 211

Schistocarpha Less. 198

Sclerocarpus Jacq. 186, 189

Scolymus L. 89

Semiria D.J.N. Hind 216

Semiria viscosa D.J.N. Hind 229

Semiria sp. 226

Senecio L. 125

Senecio flaccidus Less. 125

Senecio hemmendorffi Malme. 115

Senecio oleosus Vell. 130

Senecio pohlii Sch. Bip. ex Baker 130

Senecio tamoides DC. 125

Senecio viravira Hieron. 125

Sigesbeckia L. 199

Silphium L. 165

Silybum Vaill. 86

Simsia Pers. 191

Sinclairia Hook. \& Arn. 97

Sinclairiopsis Rydb. 97 
Smallanthus Mack. 199

Soaresia Sch. Bip. 104

Solidago L. 142

Solidago chilensis Meyen 140

Soliva Ruiz \& Pav. 150, 151

Sommerfeltia Less. 141

Sonchus L. 89, 90, 91

Sonchus oleraceus L. 95

Sphaereupatorium (O. Hoffm.) Kuntze ex B.L. Rob. 220

Sphagneticola O. Hoffm. 190

Sphagneticola trilobata (L.) Pruski 206, 207

Spilanthes Jacq. 188

Staurochlamys Baker 166, 167

Stenachaenium Benth. 155, 156

Stenachaenium megapotamicum (Spreng.) Baker 159

Stenocephalum Sch. Bip. 110

Stenopadus S.F. Blake 61, 69

Stenopadus andicola Pruski 67

Stenopadus aracaënsis Pruski 68

Stenopadus talaumifolius S.F. Blake 50, 93

Stenophalium A. Anderb. 131

Stevia Cav. 211

Stevia grazielae A.S. Quaresma \& J.N. Nakaj. 226

Stevia heptachaeta DC. 230

Stevia rebaudiana (Bertoni) Bertoni 20

Steyermarkina R.M. King \& H. Rob. 219

Steyermarkina dusenii (Malme) R.M. King \& H. Rob. 226

Stifftia J.C. Mikan 61, 63

Stifftia chrysantha J.C. Mikan 50

Stifftia fruticosa (Vell.) D.J.N. Hind \& Semir 50

Stifftia hatschbachii H. Rob. 93

Stifftia sp. 235

Stilpnopappus Mart. ex DC. 
Stilpnopappus tomentosus Mart. ex DC. 114

Stomatanthes R.M. King \& H. Rob. 221

Stomatanthes dictyophyllus (DC.) H. Rob. 230

Stomatochaeta Maguire \& Wurdack 61, 67, 68, 69

Stomatochaeta condensata (Baker) Maguire \& Wurdack 93, 94

Strophopappus DC. 109

Strophopappus glomeratus (Gardner) R. Esteves 118

Struchium P. Browne 108

Struchium sparganophorum (L.) Kuntze 115

Stylotrichium Mattf. 213

Stylotrichium rotundifolium Mattf. 230

Symphyopappus Turcz. 219

Symphyopappus cuneatus (DC.) Sch. Bip. ex Baker 230

Symphyotrichum Nees 142

Symphyotrichum squamatum (Spreng.) G.L. Nesom 140

Synedrella Gaertn. 165, 186, 191

Synedrella nodiflora (L.) Gaertn. 206

Synedrellopsis Hieron. \& Kuntze ex Kuntze 186, 189

Tagetes L. 176, 177

Tagetes minuta L. 203, 205

Tanacetum L. 150

Tanacetum cinerariifolium (Trev.) Sch. Bip. 20

Tanacetum vulgare L. 159

Taraxacum F.H. Wigg. 89, 90, 91

Taraxacum officinale Weber ex F.H. Wigg. 93, 95

Tarchonanthus L. 81

Teixeiranthus R.M. King \& H. Rob. 213

Telmatophila Mart. ex Baker 104

Tessaria Ruiz \& Pav. 155, 156

Tetragonotheca L. 165

Thymopsis Benth. 182

Tilesia G. Mey. 189

Tilesia baccata (L.f.) Pruski 207

Tithonia Desf. ex Juss. 186, 191 
Tithonia rotundifolia (Mill.) S.F. Blake. 207

Trichocline Cass. 45, 46

Trichocline catharinensis Cabrera var. discolor Cabrera 35

Trichocline linearifolia Malme 45

Trichocline macrocephala Less. 49, 50

Trichogonia (DC.) Gardner 215

Trichogonia campestris Gardner 226

Trichogonia villosa Sch. Bip. ex Baker 230

Trichogoniopsis R.M. King \& H. Rob. 215

Trichogoniopsis adenantha (DC.) R.M. King \& H. Rob. 230

Trichospira Kunth 103

Trichospira verticillata (L.) S.F. Blake 115

Tridax L. 198

Trioncinia (F. Muell.) Veldkamp 166

Trixis P. Browne 53, 54

Trixis glutinosa D. Don 35

Trixis lessingii DC. 50

Trixis verbascifolia (Gardner) S.F. Blake 50

Unxia L.f. 199

Urmenetea Phil. 57

Urolepis (DC.) R.M. King \& H. Rob. 217

Verbesina L. 191

Vernonanthura H. Rob. 109

Vernonanthura brasiliana (L.) H. Rob. 118

Vernonanthura divaricata (Spreng.) H. Rob. 115

Vernonia Schreb. 101, 109

Vernonia echioides Less. 101

Vernonia incana Less 101

Vinicia M. Dematt. 106

Vittetia R.M. King \& H. Rob. 217

Vittetia orbiculata (DC.) R.M. King \& H. Rob. 230

Wedelia Jacq. 186, 190

Wedelia goyazensis Gardner 206

Wunderlichia Riedel ex Benth. 61, 67, 69 
Wunderlichia azulensis Maguire \& G.M. Barroso 68

Wunderlichia mirabilis Riedel ex Baker 94

Wunderlichia crulsiana Taub. 94

Wunderlichia insignis Baill. 94

Wunderlichia senae Glaz. ex Maguire \& G.M. Barroso 69

Xanthium L. 186, 187

Xanthium spinosum L. 206

Xerochrysum Tzvelev 134

Xerochrysum bracteatum (Vent.) Tzvelev 133

Xiphochaeta Poepp. 109

Youngia Cass. 89,90,91

Youngia japonica (L.) DC. 90

Zinnia L. 186, 188

Zinnia elegans Jacq. 206, 207 


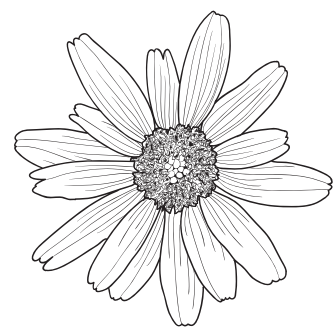

Este livro foi publicado no formato 17 x $24 \mathrm{~cm}$ utilizando as fontes Swift e Scala Sans Miolo em papel Off-Set $75 \mathrm{~g} / \mathrm{m} 2$ Impresso na EDUFBA

Capa em Cartão Triplex 350 g/m2 Impressa na I. Bigraf Tiragem: 500 exemplares 